\title{
Technical Documentation in Support of the Project-Specific Analysis for Construction and Operation of the National Ignition Facility
}

Environmental Assessment Division Argonne.National Laboratory

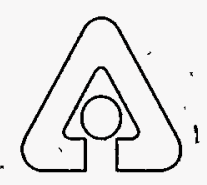

Operated by The University of Chicago, under Contract W-31-109-Eng-38, for the United States Department of Energy 


\section{Argonne National:Laboratory}

Argonne National Laboratory, with facilities in the states of Illinois and Idaho, is owned by the United States Government, and operated by the University of Chicago under the provisions of a contract with the Department of Energy. -

This technical memo is a product of Argonne's Environmental Assessment Division (EAD). For information on the division's scientific and engineering activities, contact:

$$
\begin{aligned}
& \text { Director, Environmental Assessment Division } \\
& \text { Argonne National Laboratory } \\
& \text { Argonne, Illinois 60439-4815 } \\
& \text { Telephione (630) 252-3107 }
\end{aligned}
$$

Presented in this technical memo are preliminary results of ongoing work or work that is more limited in scope and depth than that described in formal reports issued by the EAD.

Publishing support serviceș wëre provided by Argonne's Information and Publishing Division (for more.information, see IPD's home page: http://www.ipd.anl.gov/):

\section{Disclaimer}

This report was prepared as an account of wotk sponsored by an agency of the United States Government: Neither the United States Government nor ány agency thereof, nor any of their employees, makes any warranty, express or implied, or assumes any legal liability or responsibility for the accuracy, completeness, or usefulness of any information, apparatus, product, of process disclosed, or represents that its use would not infringe privately owned rights. Reference herein to any specific commercial product, process, or service by trade name, trademark, manufacturer, or otherwise, doeş not necessiarily constitute. or imply its endọrsement, recommendation, or favoring by the United States Government or any agency thereof. 'The views and opinions of authors expressed herein do not necessarily state or reflect those of the United States Government or any agency thereof.

Reproduced directly from the best available copy.

Available to DOE and DOE contractors from the Office of Scientific and Technical Information, P.O. Box 62, Oak Ridge, TN 37831; prices available from (423) 576-8401.

Available to the public from the National Technical Information Service, U.S. Department of Commerce, 5285. Port Rioyal Road, Springfield, VA' 22161. 


\section{Technical Documentation in Support of the Project-Specific Analysis for Construction and Operation of the National Ignition Facility}

by M.A. Lazaro, W. Vinikour, T. Allison, ${ }^{\star}$ J. Arnish, T. Bingaman, ${ }^{\star}$ B. Biwer, Y.S. Chang, K.-J. Hong, D. Kuhaneck, M.R. Monarch, E.D. Pentecost, A.J. Policastro, R. Seiden, ${ }^{\star}$ and D.R. Wernette*

Environmental Assessment Division,

Argonne National Laboratory, 9700 South Cass Avenue, Argonne, Illinois 60439

September 1996

Prepared for

U.S. Department of Energy, Office of Defense Programs,

Oakland Area Office, Oakland, California

- Allison and Wernette are affiliated with ANL's Decision and Information Sciences Division; Bingaman and Seiden are with Brown and Root Environmental, Gaithersburg, Maryland. 


\section{DISCLAIMER}

Portions of this document may be illegible in electronic image products. Images are produced from the best available original document. 


\section{CONTENTS}

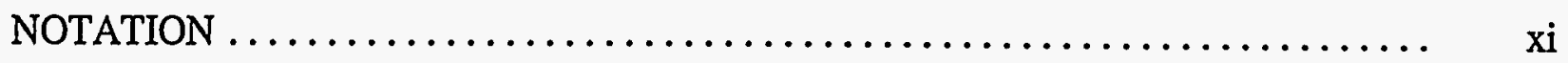

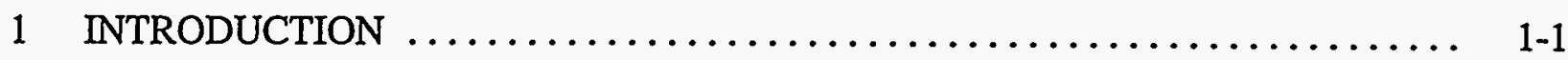

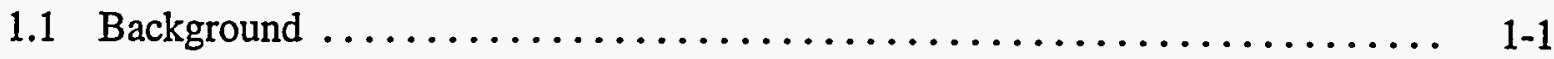

1.2 Document Organization $\ldots \ldots \ldots \ldots \ldots \ldots \ldots \ldots \ldots \ldots \ldots \ldots \ldots, 1-2$

1.2.1 Section 2: Air Quality and Acoustics $\ldots \ldots \ldots \ldots \ldots \ldots \ldots \ldots \ldots, 1-2$

1.2.2 Section 3: Socioeconomics $\ldots \ldots \ldots \ldots \ldots \ldots \ldots \ldots \ldots \ldots \ldots \ldots, 1-2$

1.2.3 Section 4: Radiation and Hazardous Chemicals ............... 1-3

1.2.4 Section 5: Threatened, Endangered, and Rare Species ........... 1-3

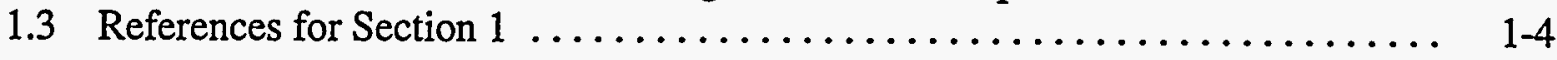

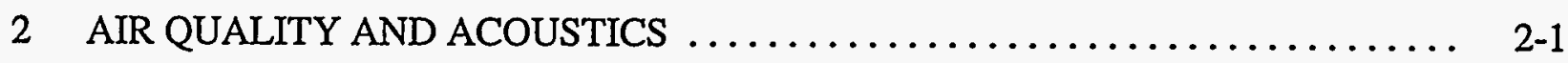

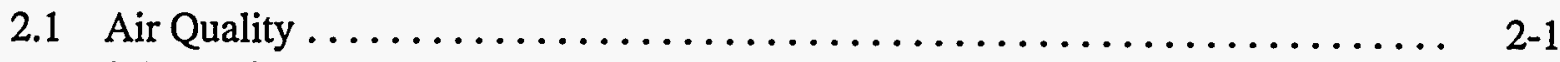

2.1.1 Affected Environment ........................... 2-1

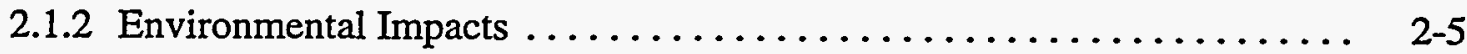

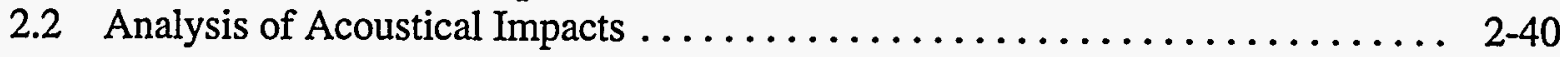

2.2.1 Modified Composite Noise Rating $\ldots \ldots \ldots \ldots \ldots \ldots \ldots \ldots \ldots . \ldots \ldots$

2.2.2 Assumptions and Results for Composite Noise Rating Analysis ....... 2-44

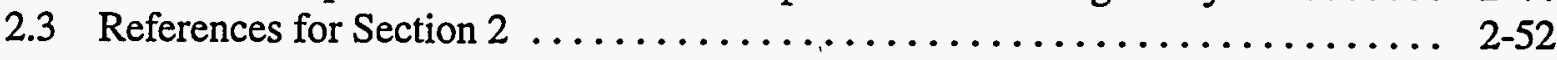

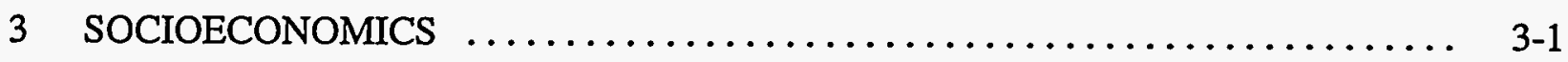

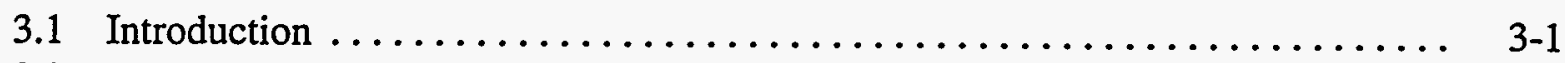

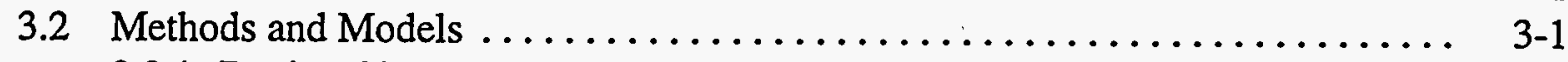

3.2.1 Regional Economics ............................ $3-3$

3.2.2 Population In-Migration $\ldots \ldots \ldots \ldots \ldots \ldots \ldots \ldots \ldots \ldots \ldots \ldots \ldots \ldots, 3-7$

3.2 .3 Housing $\ldots \ldots \ldots \ldots \ldots \ldots \ldots \ldots \ldots \ldots \ldots \ldots \ldots \ldots \ldots \ldots \ldots \ldots, 3-13$

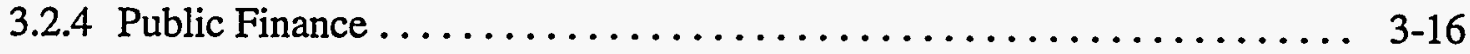

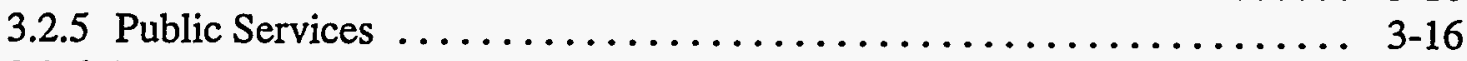

3.2.6 Local Transportation ............................... 3-16

3.2.7 Environmental Justice ............................ 3-18

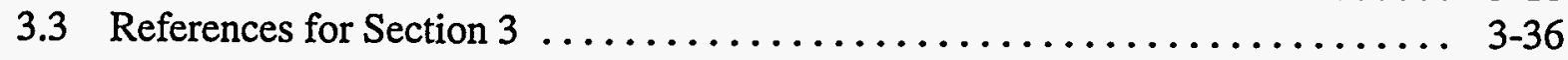

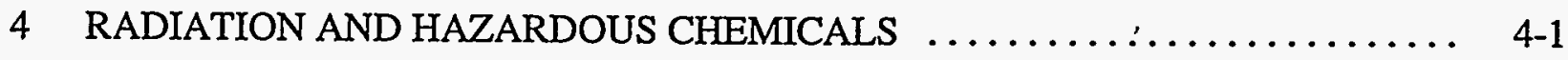

4.1 Radiological Impact Assessment ........................... 4-1

4.1.1 Sources of Radiation $\ldots \ldots \ldots \ldots \ldots \ldots \ldots \ldots \ldots \ldots \ldots \ldots \ldots \ldots, 4,1$

4.1.2 Assessment Methods ........................... 4-2 


\section{CONTENTS (Cont.)}

4.1.3 Model Input $. \ldots \ldots \ldots \ldots \ldots \ldots \ldots \ldots \ldots \ldots \ldots \ldots \ldots \ldots, 4,3$

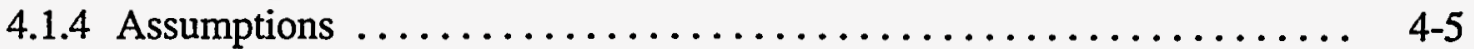

4.2 Hazardous Chemical Impact Assessment $\ldots \ldots \ldots \ldots \ldots \ldots \ldots \ldots \ldots \ldots$. $4-6$

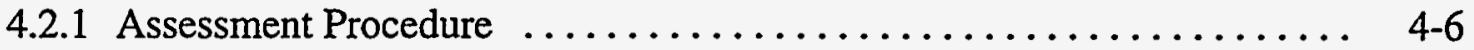

4.2.2 Mercury Release Scenarios and Results ................. 4-11

4.2.3 Alumina and Silicate Release Scenarios and Results ............ 4-16

4.2.4 Carbonyl Fluoride and Hydrogen Fluoride

Release Scenarios and Results . ..................... 4-17

4.2.5 Propane Gas Release Scenario and Results ................ 4-19

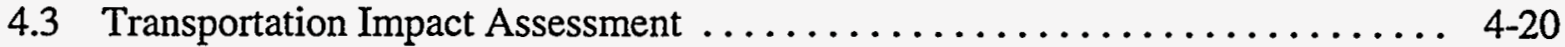

4.3.1 Methods ...................................... 4-22

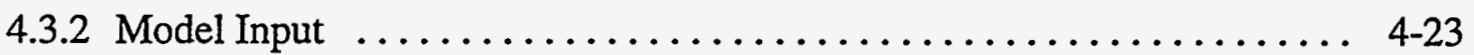

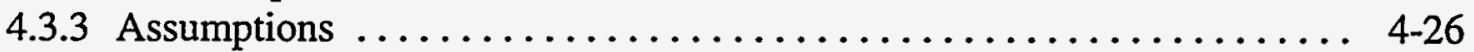

4.3.4 Per-Shipment Risk Factors and MEI Consequences $\ldots \ldots \ldots \ldots \ldots \ldots$ 4-27

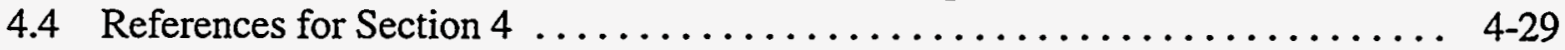

5 THREATENED, ENDANGERED, AND RARE SPECIES $\ldots \ldots \ldots \ldots \ldots \ldots .5-1$

\section{FIGURES}

3.1 Industry Share of Total NIF Construction Cost $\ldots \ldots \ldots \ldots \ldots \ldots \ldots \ldots .3-7$

3.2 Relative Regional Economic Impact Comparison $\ldots \ldots \ldots \ldots \ldots \ldots \ldots \ldots$ 3-8

3.3 Impacts of NIF Spending on the LLNL Regional Economy ............. 3-9

3.4 Impacts of NIF Spending on the LANL Regional Econiomy $\ldots \ldots \ldots \ldots \ldots .3-9$

3.5 Impacts of NIF Spending on the NTS/NLVF Regional Economy $\ldots \ldots \ldots \ldots . . .10$

3.6 Impacts of NIF Spending on the SNL Regional Economy $\ldots \ldots \ldots \ldots \ldots \ldots .3-10$

3.7 Economic and Demographic Impacts at LLNL $\ldots \ldots \ldots \ldots \ldots \ldots \ldots \ldots \ldots \ldots \ldots \ldots$

3.8 Economic and Demographic Impacts at LANL $\ldots \ldots \ldots \ldots \ldots \ldots \ldots \ldots \ldots \ldots \ldots \ldots$

3.9 Economic and Demographic Impacts at NTS/NLVF $\ldots \ldots \ldots \ldots \ldots \ldots \ldots \ldots .12$

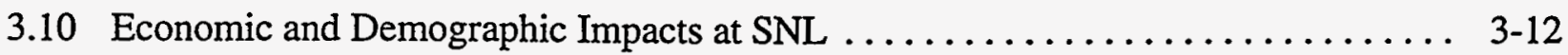




\section{FIGURES (Ċont.)}

3.11 LLNL Potential NIF Site Percentage of Minority Population Above/Below State Average by Census Block Group $\ldots \ldots \ldots \ldots \ldots \ldots \ldots \ldots \ldots \ldots . . \ldots \ldots .24$

3.12 LLNL Potential NIF Site Percentage of Low-Income Population Above/Below State Average by Census Block Group $\ldots \ldots \ldots \ldots \ldots \ldots \ldots \ldots \ldots \ldots \ldots . \ldots \ldots \ldots$

3.13 LANL Potential NIF Site Percentage of Minority Population Above/Below State Average by Census Block Group $\ldots \ldots \ldots \ldots \ldots \ldots \ldots \ldots \ldots \ldots . . \ldots \ldots$

3.14 LANL Potential NIF Site Percentage of Low-Income Population Above/Below State Average by Census Block Group . . . . . . . . . . . . .

3.15 NTS Potential NIF Site Percentage of Minority Population Above/Below

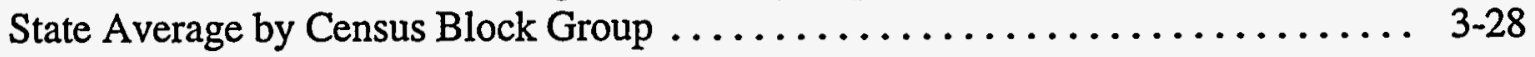

3.16 NTS Potential NIF Site Percentage of Low-Income Population Above/Below State Average by Census Block Group $\ldots \ldots \ldots \ldots \ldots \ldots \ldots \ldots \ldots \ldots . . \ldots \ldots$

3.17 NLVF Potential NIF Site Percentage of Minority Population Above/Below State Average by Census Block Group $\ldots \ldots \ldots \ldots \ldots \ldots \ldots \ldots \ldots \ldots . \quad 3-30$

3.18 NLVF Potential NIF Site Percentage of Low-Income Population Above/Below State Average by Census Block Group $. \ldots \ldots \ldots \ldots \ldots \ldots \ldots \ldots \ldots \ldots . .3-31$

3.19 SNL Potential NIF Site Percentage of Minority Population Above/Below

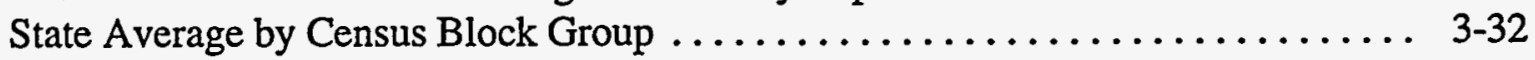

3.20 SNL Potential NIF Site Percentage of Low-Income Population Above/Below State Average by Census Block Group $\ldots \ldots \ldots \ldots \ldots \ldots \ldots \ldots \ldots \ldots \ldots . . \ldots \ldots$

3.21 Minority Population Above/Below State Average by Census Block Group within $8 \mathrm{~km}$ of the NLVF Site

3.22 Low-Income Population Above/Below State Average by Census Block Group within $8 \mathrm{~km}$ of the NLVF Site 


\section{TABLES}

2.1 Ambient Air Quality Standards Applicable to the National Ignition

Facility Candidate Sites $\ldots \ldots \ldots \ldots \ldots \ldots \ldots \ldots \ldots \ldots \ldots \ldots, 2-2$

2.2 Maximum Allowable Prevention of Significant Deterioration

Concentration Increments $\ldots \ldots \ldots \ldots \ldots \ldots \ldots \ldots \ldots \ldots \ldots \ldots \ldots \ldots \ldots \ldots \ldots, 2-5$

2.3 State of California and National Ambient Air Quality Standards ........... 2-6

2.4 Livermore Old First Street Ambient Air Monitoring Station Criteria

Pollutant Monitoring Data for $1993 \ldots \ldots \ldots \ldots \ldots \ldots \ldots \ldots \ldots \ldots . . \ldots \ldots$

2.5 State of Nevada and National Ambient Air Quality Standards ............. 2-9

2.6 Clark County, Nevada, and National Ambient Air Quality Standards ........ 2-10

2.7 1994 Ambient Air Concentrations in Vicinity of North Las Vegas Facility ...... . 2-11

2.8 1993 Ambient Air Concentrations in Vicinity of Sandia National

Laboratories ..................................... 2-12

2.9 Estimated Number of Months Required for Site Clearing and Facility

Construction for the First Year $\ldots \ldots \ldots \ldots \ldots \ldots \ldots \ldots \ldots \ldots \ldots \ldots . . \ldots \ldots \ldots, 2-12$

2.10 Estimated Construction Activity Air Pollution Emission Summary for

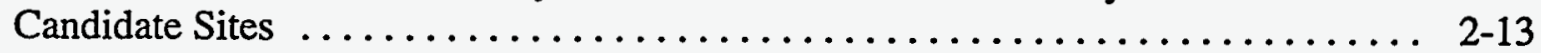

2.11 Estimated Site-Clearing Construction Vehicle Exhaust Emissions for

Each Candidate Site ................................ 2-14

2.12 Emission Factors for Site-Clearing Construction Equipment Exhaust . . . . . . . 2-15

2.13 Estimated Facility Construction Air Pollutant Emissions .............. 2-15

2.14 Uncontrolled $\mathrm{PM}_{10}$ Emission Factors Used to Develop Construction

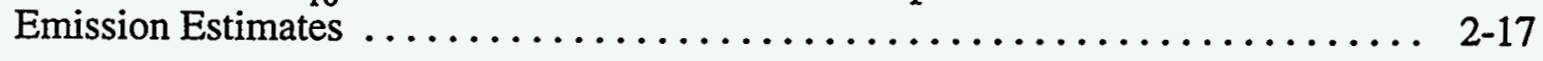

2.15 Estimated Annual $\mathrm{PM}_{10}$ Fugitive Dust Emissions Associated with Construction Activities at National Ignition Facility Candidate Sites $\ldots \ldots \ldots \ldots \ldots \ldots .2-20$

2.16 Total National Ignition Facility Estimated Operating Emissions at Candidate Sites 


\section{TABLES (Cont.)}

2.17 Non-Attainment Area Federal Facility Emission Limits Requiring

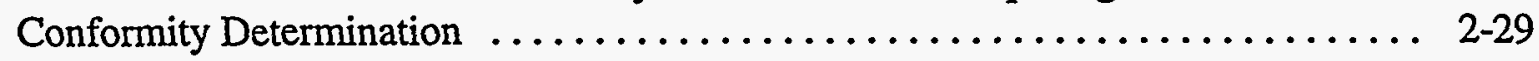

2.18 Maintenance Area Federal Facility Emission Limits Requiring

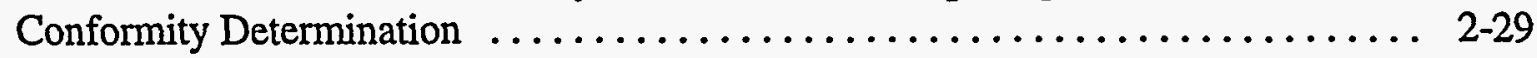

2.19 Estimated Design Annual Energy Requirements for the National

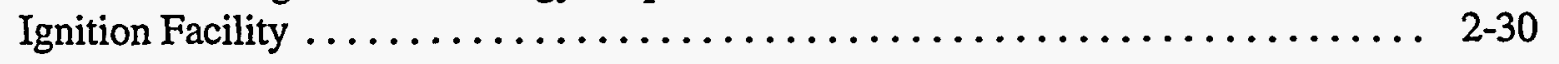

2.20 Site-Specific Energy Demand for New Support Buildings $\ldots \ldots \ldots \ldots \ldots \ldots \ldots$ 2-30

2.21 Air Pollutant Emission Factors for External Combustion Units Burning

Natural Gas or LPG and for Stationary Internal Combustion Engines ......... 2-31

2.22 Facilities Required for National Ignition Facility Operations at Each

Candidate Site

2.23 Laser and Target Area Building Estimated Annual Fuel Combustion

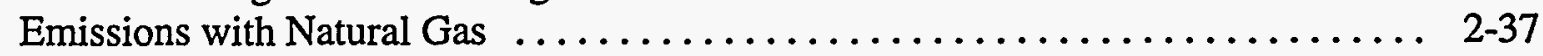

2.24 Laser and Target Area Building Estimated Annual Fuel Combustion

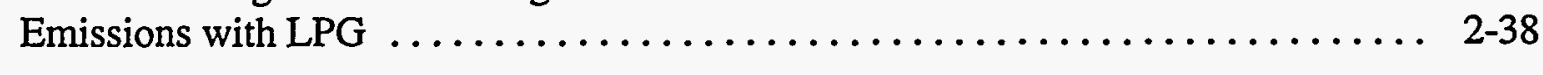

2.25 Estimated Fuel Combustion Emissions with Natural Gas for National Ignition

Facility Support Facilities at LLNL, LANL, NLVF, and SNL $\ldots \ldots \ldots \ldots \ldots .2-38$

2.26 Estimated Percentage of Urban Population Residing in Areas with Various

Day-Night Noise Levels $\ldots \ldots \ldots \ldots \ldots \ldots \ldots \ldots \ldots \ldots \ldots \ldots \ldots . \ldots \ldots \ldots \ldots$

2.27 Typical Yearly Day-Night Average Sound Levels for Neighborhoods with

No Well-Defined Source of Noise other than Usual Transportation Noise $\ldots \ldots \ldots \quad 2-42$

2.28 Sound Power Levels of Equipment Modeled for Analysis of Noise Impact

during National Ignition Facility Construction Phase $\ldots \ldots \ldots \ldots \ldots \ldots \ldots .2-43$

2.29 Sound Attenuation Rates for Molecular Absorption for "Standard Day"

Conditions and for "Anomalous Excess Attenuation" ................ 2-44

2.30 Normalizing Factors for Composite Noise Rating Results ............. 2-46

2.31 Summary of Modeling and Analysis - Lawrence Livermore National

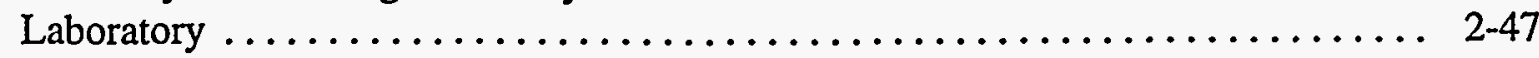




\section{TABLES (Cont.)}

2.32 Summary of Modeling and Analysis — Los Alamos National Laboratory ...... 2-48

2.33 Summary of Modeling and Analysis — Nevada Test Site ............. 2-49

2.34 Summary of Modeling and Analysis — North Las Vegas Facility .......... 2-50

2.35 Summary of Modeling and Analysis — Sandia National Laboratories ........ 2-51

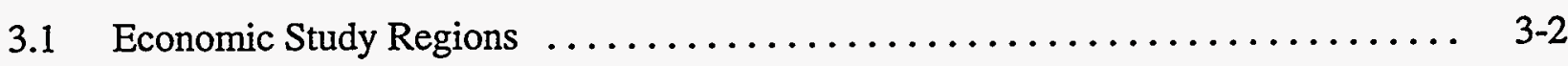

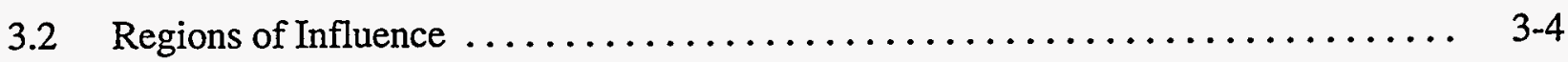

3.3 Regional Economic Impact Analysis Comparison - Baseline and NIF Alternative Employment Forecasts $\ldots \ldots \ldots \ldots \ldots \ldots \ldots \ldots \ldots \ldots .6 \ldots \ldots$

3.4 Site-Specific In-Migration Rate Assumptions $\ldots \ldots \ldots \ldots \ldots \ldots \ldots \ldots \ldots . \ldots \ldots$

3.5 Employment Impact Summary - U.S. and Regional Economies ........... 3-14

3.6 Roadway Level-of-Service Letter Designations and Definitions $\ldots \ldots \ldots \ldots \ldots$ 3-18

3.7 Percentages of Populations within $80 \mathrm{~km}$ of National Ignition Facility Candidate Sites and of States in Which Those Sites Are Located, by Minority

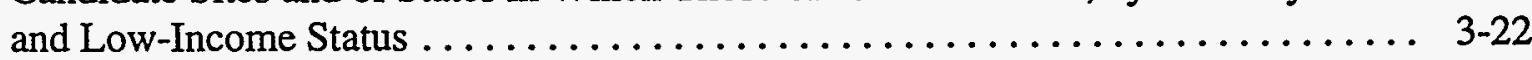

3.8 Correlation Coefficients for Distance to National Ignition Facility Candidate Sites and Percentage Minority or Percentage Low-Income Populations

4.1 Radiological Source Terms from Normal National Ignition

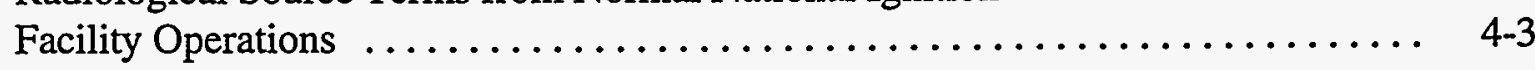

4.2 Radiological Source Terms for a Postulated Accident at the National Ignition Facility $\ldots \ldots \ldots \ldots \ldots \ldots \ldots \ldots \ldots \ldots \ldots . . \ldots \ldots, 4$

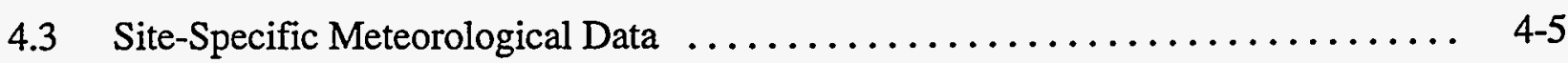

4.4 Location of Maximally Exposed Individual $\ldots \ldots \ldots \ldots \ldots \ldots \ldots \ldots \ldots \ldots \ldots \ldots \ldots$

4.5 Estimated Chemical Inventories for the National Ignition Facility

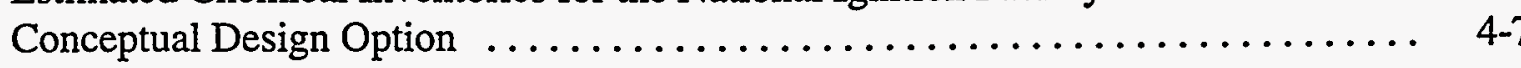




\section{TABLES (Cont.)}

4.6 Estimated Chemical Inventories for the National Ignition Facility

Enhanced Option.$\ldots \ldots \ldots \ldots \ldots \ldots \ldots \ldots \ldots \ldots \ldots \ldots \ldots \ldots \ldots \ldots$

4.7 Summary of Chemical Accident Release Scenarios for the

National Ignition Facility

4.8 Summary of Mercury Release Scenario Predictions at the Five National

Ignition Facility Candidate Sites

4.9 Summary of Alumina/Silicate Release Scenario Predictions at the Five

National Ignition Facility Candidate Sites for Conceptual Design

and Enhanced Options

4.10 Summary of Carbonyl Fluoride Release Scenario Predictions at the Five

National Ignition Facility Candidate Sites for Conceptual Design

and Enhanced Options .

4.11 Summary of Hydrogen Fluoride Release Scenario Predictions at the

Five National Ignition Facility Candidate Sites for Conceptual Design

and Enhanced Options

4.12 Conditional Probabilities of Transportation Accidents by Severity Category

and Population Density Zone

4.13 Release, Aerosolized, and Respirable Fractions for Type A Packages

Filled with Tritium Targets .

4.14 Radiological Per-Shipment Risk Factors $\ldots \ldots \ldots \ldots \ldots \ldots \ldots \ldots \ldots \ldots \ldots$. $\ldots \ldots$.

4.15 Nonradiological Vehicular Per-Shipment Risk Factors $\ldots \ldots \ldots \ldots \ldots \ldots \ldots \ldots$ 4-28

4.16 Radiological Impacts Resulting from a Severity Category VIII Accident for

Each Shipment Configuration of Tritium Targets .................

5.1 Threatened, Endangered, and Rare Species Potentially Present at

Lawrence Livermore National Laboratory

5.2 Threatened, Endangered, and Rare Species Potentially Present at

Los Alamos National Laboratory

5.3 Threatened, Endangered, and Rare Species Potentially Present at Nevada Test Site 


\section{TABLES (Cont.)}

5.4 Threatened, Endangered, and Rare Species Potentially Present at North Las Vegas Facility

5.5 Threatened, Endangered, and Rare Species Potentially Present at Sandia National Laboratories 


\section{NOTATION}

\section{Abbreviations}

AADT

ABCAQCB

ACGIH

BAAQMD

BEA

CARB

CFR

CNR

$\mathrm{CO}$

DBHCC

DOE

EPA

ERPG-2

FWS

ICF

I-O

IP

ISCT

LANL

$\mathrm{L}_{\mathrm{dn}}$

LLNL

LPG

MEI

NAAQS

NDEP

NEPA

NIF

NLVF

NMEIB

$\mathrm{NO}_{2}$

$\mathrm{NO}_{\mathrm{x}}$

NRC average annual daily traffic

Albuquerque-Bernalillo County Air Quality Control Board

American Conference of Government Industrial Hygienists

Bay Area Air Quality Management District

Bureau of Economic Analysis

California Environmental Protection Agency Air Resources Board

Code of Federal Regulations

composite noise rating

carbon monoxide

District Board of Health of Clark County

U.S. Department of Energy

U.S. Environmental Protection Agency

Emergency Response Planning Guideline-2

U.S. Fish and Wildlife Service

inertial confirment fusion

input-output

Implementation Plan

Industrial Source Complex Short Term Model

Los Alamos National Laboratory

day-night sound level

Lawrence Livermore National Laboratory

liquefied petroleum gas

maximally exposed individual

National Ambient Air Quality Standards

Nevada Division of Environmental Protection

National Environmental Policy Act

National Ignition Facility

North Las Vegas Facility

New Mexico Environmental Improvement Board

nitrogen oxide

nitrogen oxides

U.S. Nuclear Regulatory Commission 
$\mathrm{O}_{3}$

OSHA

$\mathrm{Pb}$

PEIS

PFIB

PHA

$\mathrm{PM}_{10}$

PSA

PSD

RIMS

ROI

SNL

$\mathrm{SO}_{2}$

SSM

TLV

TLV-TWA

TSR

UC

VKT

VOC

WBS ozone

Occupational Safety and Health Administration

lead

programmatic environmental impact statement

perfluoroisobutylene

Preliminary Hazards Analysis

particulate matter with a diameter equal to or less than 10 micrometers

project-specific analysis

prevention of significant deterioration

Regional Input-Output Modeling System

region of influence

Sandia National Laboratories

sulfur dioxide

Stockpile Stewardship and Management

threshold limit value

threshold limit value, time-weighted average

tritium supply and recycling

University of California

vehicle-kilometer(s) traveled

volatile organic compound

work breakdown structure

Units of Measure

$\begin{array}{llll}{ }^{\circ} \mathrm{C} & \text { degrees Celsius } & \mathrm{Hz} & \text { hertz } \\ { }^{\circ} \mathrm{F} & \text { degrees Fahrenheit } & \mathrm{in} . & \text { inch(es) } \\ \mathrm{Btu} & \text { British thermal unit(s) } & \mathrm{kg} & \text { kilogram(s) } \\ \mathrm{Ci} & \text { curie(s) } & \mathrm{km} & \text { kilometer(s) } \\ \mathrm{cm} & \text { centimeter(s) } & \mathrm{L} & \text { liter(s) } \\ \mathrm{d} & \text { day(s) } & \mathrm{lb} & \text { pound(s) } \\ \mathrm{dBA} & \text { decibel(s), A-weighted } & \mathrm{m} & \text { meter(s) } \\ \mathrm{ft} & \text { foot (feet) } & \mathrm{m}^{2} & \text { square meter(s) } \\ \mathrm{ft}^{2} & \text { square foot (feet) } & \mathrm{m}^{3} & \text { cubic meter(s) } \\ \mathrm{ft}^{3} & \text { cubic foot (feet) } & \mathrm{mg} & \text { milligram(s) } \\ \text { gal } & \text { gallon(s) } & \mathrm{mi} & \text { mile(s) } \\ \mathrm{h} & \text { hour(s) } & \mathrm{min} & \text { minute(s) } \\ \text { ha } & \text { hectare(s) } & \mathrm{MJ} & \text { megajoule(s) }\end{array}$




\begin{tabular}{|c|c|c|c|}
\hline $\mathrm{mm}$ & millimeter(s) & S & second(s) \\
\hline mo & month(s) & $\mathrm{t}$ & metric ton(s) \\
\hline $\mathrm{mph}$ & mile(s) per hour & & (1,000 kilograms) \\
\hline MW & megawatt(s) & $\mu \mathrm{g}$ & microgram(s) \\
\hline $\mathrm{Oz}$ & ounce(s) & $\mathrm{yd}^{2}$ & square yard(s) \\
\hline ppm & part(s) per million & $y d^{3}$ & cubic yard(s) \\
\hline ppmv & $\begin{array}{l}\text { part(s) per million (by } \\
\text { volume) }\end{array}$ & yr & year(s) \\
\hline
\end{tabular}




\title{
TECHNICAL DOCUMENTATION IN SUPPORT OF THE PROJECT-SPECIFIC ANALYSIS FOR CONSTRUCTION AND OPERATION OF THE NATIONAL IGNITION FACILITY
}

\author{
by \\ M.A. Lazaro, W. Vinikour, T. Allison, J. Arnish, T. Bingaman, B. Biwer, \\ Y.S. Chang, K.-J. Hong, D. Kuhaneck, M.R. Monarch, E.D. Pentecost, \\ A.J. Policastro, R. Seiden, and D.R. Wernette
}

\section{INTRODUCTION}

\subsection{BACKGROUND}

This document provides information that supports or supplements the data and impact analyses presented in the National Ignition Facility (NIF) Project-Specific Analysis (PSA). The NIF PSA constitutes Appendix I of the U.S. Department of Energy's (DOE's) Programmatic Environmental Impact Statement (PEIS) for the Stockpile Stewardship and Management (SSM) Program (DOE 1996). The purposes of NIF are to achieve fusion ignition in the laboratory for the first time with inertial confinement fusion (ICF) technology and to conduct high-energy-density experiments in support of national security and civilian applications. NIF is an important element in the DOE's science-based SSM Program, a key mission of which is to ensure the reliability of the nation's enduring stockpile of nuclear weapons. NIF would also advance the knowledge of basic and applied high-energy-density science and bring the nation a large step closer to developing fusion energy for civilian use.

The NIF PSA includes evaluations of the potential environmental impacts of constructing and operating the facility at one of five candidate sites and for two design options. The candidate sites include the Lawrence Livermore National Laboratory (LLNL) in Livermore, California (preferred site); Los Alamos National Laboratory (LANL) in Los Alamos, New Mexico; Nevada Test Site (NTS) near Mercury Base, Nevada; North Las Vegas Facility (NLVF) in North Las Vegas, Nevada; and Sandia National Laboratories (SNL) in Albuquerque, New Mexico. The design options evaluated are the Conceptual Design Option, which would use indirect drive deuterium-tritium fuel targets, and the Enhanced Option, which would use both indirect and direct drive deuterium-tritium fuel targets. The analyses conducted for the PSA indicate relatively small environmental impacts and very little difference in the impacts among the siting and operational alternatives (see Chapter I.4 of the PSA). 


\subsection{DOCUMENT ORGANIZATION}

This document provides selected technical support information for the site-specific data, assessment methods, and regulatory framework for analyses conducted for air quality and acoustics, socioeconomics, radiation and hazardous chemicals, transportation impacts, and federal- and stateprotected plant and animal species that could inhabit or visit the NIF candidate sites. These topical areas typically require evaluation of extensive databases or the use of modeling that is too comprehensive for extended discussion in the main text of an assessment document. Where appropriate, assumptions and rationale are provided in this document to support the methods selected.

Organization of this document is as follows: Section 1: Introduction, Section 2: Air Quality and Acoustics, Section 3: Socioeconomics, Section 4: Radiation and Hazardous Chemicals, and Section 5: Threatened, Endangered, and Rare Species. A synopsis of the technical information included in Sections 2 through 5 is provided below.

\subsubsection{Section 2: Air Quality and Acoustics}

Section 2 provides data on background (ambient baseline) concentrations of criteria air pollutants and NIF-related pollutant emissions for the five candidate sites. Air quality modeling used to predict emission concentrations resulting from site clearing and NIF operation is also discussed. Air quality analysis for NIF construction (both site-clearing and facility-construction phases) focused on fugitive particulate matter emissions from soil disturbance and on exhaust emissions from construction vehicles. Air quality modeling analysis for particulate matter emissions from site clearing at each candidate site is also discussed. Detailed information and assumptions used in the analysis are provided for air pollutant emission sources and levels, air pollutant emission factors, and source operating activity from NIF operations. Section 2 also provides data supporting the impact assessments for acoustics presented in the PSA. Included are description of the analytical methods used, discussion of assumptions used in the analyses, and presentation of the analysis results for each candidate site.

\subsubsection{Section 3: Socioeconomics}

Section 3 describes the methods, models, assumptions, and supporting data sources used to assess the potential socioeconomic impacts from constructing and operating NIF at each candidate site. The approach used for determining socioeconomic impacts of NIF was consistent with the overall approach used for the PEIS for the SSM Program. Because this approach is similar to that used in the Tritium Supply and Recycling PEIS (DOE 1995), only those aspects that differ from that PEIS are addressed in detail in this document. The potential socioeconomic impacts addressed 
include regional economics, population in-migration, housing, public finance, public services, and local transportation. Also addressed under socioeconomics is environmental justice (i.e., potential disproportionate effects on minority and low-income communities). Section 3 of this document details the definitions, methods, and assumptions used to determine potential environmental justice effects from operation of NIF at each candidate site. The potential environmental justice impacts identified by the analysis for each site are also discussed.

\subsubsection{Section 4: Radiation and Hazardous Chemicals}

Section 4 presents the methods, data, and assumptions used to estimate radiological, hazardous chemical, and material transportation impacts that could result from operation of NIF at each candidate site. Information provided for the radiological impact assessment includes sources of radiation, assessment methods, model input (i.e., source term data, meteorological data, population data, and locations of maximally exposed individuals), and assumptions. This information was used to assess potential radiological impacts from normal NIF operations and from postulated accidents. The impact assessment is provided in Chapter I.4 of the PSA. Information provided for the hazardous chemical impact assessment includes a determination of potentially hazardous chemicals and descriptions of scenarios that could cause an accidental release of those chemicals. Section 4 also provides information required to calculate transportation impacts that could result from the shipment of tritium-filled targets from each of the target manufacturing facilities to each of the candidate NIF locations. The evaluation includes both radiological and nonradiological accident causes for both the Conceptual Design and Enhanced options. The discussion for the transportation accident assessment includes transportation routes, routine transportation risk, and transportation accident risk. Model input for the transportation assessment includes source terms and shipment configuration, accident severity categories, and material release fractions. Assumptions on release heights, population densities, and location of maximally exposed individuals are also provided. The section concludes with information on per-shipment risk factors and consequences to maximally exposed individuals.

\subsubsection{Section 5: Threatened, Endangered, and Rare Species}

Section 5 lists the federal- and state-listed plant and animal species that inhabit or could occur at each of the candidate sites. The species lists are for the entire candidate site, rather than being limited to the specific NIF location within the site. This information is presented in tabular form and includes the common and scientific names, status (federal and state), general habitat, and potential for each species to occur at the specific NIF location. Although the lists for some of the larger DOE sites are extensive, few protected species would actually occur at any of the proposed NIF locations within those sites. Furthermore, the potential for adverse impacts to any listed species is considered negligible. 


\subsection{REFERENCES FOR SECTION 1}

U.S. Department of Energy, 1995, Programmatic Environmental Impact Statement for Tritium Supply and Recycling, Vols. I and II, DOE/EIS-0161, Office of Reconfiguration, Washington, D.C.

U.S. Department of Energy, 1996, Programmatic Environmental Impact Statement for Stockpile Stewardship and Management, DOE/EIS-0236, Office of Reconfiguration, Washington, D.C. 


\section{AIR QUALITY AND ACOUSTICS}

\subsection{AIR QUALITY}

This section provides data supporting air quality assessments presented in Chapter I.4 of the NIF PSA (DOE 1996, Appendix I). The data presented in this section include ambient baseline concentrations of criteria air pollutants and estimates of NIF-related pollutant emissions. Air quality modeling used to predict emission concentrations resulting from site clearing for NIF and operation of the facility is also discussed.

\subsubsection{Affected Environment}

Background information on air quality at the five candidate sites for NIF are provided here. National Ambient Air Quality Standards (NAAQS) exist for the criteria air pollutants ozone $\left(\mathrm{O}_{3}\right)$, carbon monoxide $(\mathrm{CO})$, nitrogen dioxide $\left(\mathrm{NO}_{2}\right)$, sulfur oxides (measured as sulfur dioxide $\left[\mathrm{SO}_{2}\right]$ ), particulate matter equal to or less than $10 \mu \mathrm{m}$ in diameter $\left(\mathrm{PM}_{10}\right)$, and lead $(\mathrm{Pb})$ (Title 40 , Code of Federal Regulations, Part 50 [40 CFR 50]). Most states have also established state ambient air quality standards (AAQS) for these and, in some cases, other pollutants. Federal Prevention of Significant Deterioration (PSD) regulations limit increases in criteria pollutant concentrations resulting from emissions from new sources above a baseline concentration. The allowable concentration increases (called increments) depend on the PSD classification of the area. The smallest increases are allowed in Class I areas, the largest in Class III areas. Table 2.1 lists the air quality standards applicable to each candidate site, and Table 2.2 lists maximum allowable PSD concentrations applicable to all candidate sites. Tables 2.3 through 2.8 provide air quality data for the individual candidate sites.

The NAAQS and California State and Bay Area Air Quality Management District (BAAQMD) ambient air quality standards applicable to LLNL are presented in Table 2.3. Table 2.4 summarizes 1993 air quality monitoring data for the single BAAQMD monitor near LLNL. NAAQS and Nevada state ambient air quality standards applicable to the NTS are presented in Table 2.5. NAAQS and Clark County ambient air quality standards applicable to the NLVF are presented in Table 2.6. Table 2.7 summarizes 1994 air quality monitoring data for the Clark County monitors near NLVF, and Table 2.8 summarizes 1993 air quality monitoring data from the New Mexico Environment Department monitors near SNL. 
TABLE 2.1 Ambient Air Quality Standards Applicable to the National Ignition Facility Candidate Sites

\begin{tabular}{|c|c|c|c|c|c|c|c|c|c|}
\hline \multirow[b]{3}{*}{ Pollutant } & \multirow{3}{*}{$\begin{array}{l}\text { Averaging } \\
\text { Time }\end{array}$} & \multirow[b]{3}{*}{ Unit } & & & \multicolumn{5}{|c|}{ State Standards } \\
\hline & & & \multicolumn{2}{|c|}{ NAAQS } & \multirow{2}{*}{$\begin{array}{c}\text { California } \\
\text { (LLNL) }\end{array}$} & \multirow{2}{*}{$\begin{array}{c}\text { Nevada } \\
\text { (NTS) }\end{array}$} & \multirow{2}{*}{$\begin{array}{l}\text { Nevada } \\
\text { (NLVF) }\end{array}$} & \multirow{2}{*}{$\begin{array}{c}\text { New } \\
\text { Mexico } \\
\text { (LANL) }\end{array}$} & \multirow{2}{*}{$\begin{array}{c}\text { New } \\
\text { Mexico } \\
\text { (SNL) }\end{array}$} \\
\hline & & & Primary ${ }^{\mathfrak{a}}$ & Secondary & & & & & \\
\hline \multicolumn{10}{|l|}{ Criteria Pollutants } \\
\hline \multirow[t]{3}{*}{ Carbon monoxide } & Annual & ppmv & $-{ }^{b}$ & - & - & - & 一 & - & 4 \\
\hline & 8 hours & ppmv & 9.0 & - & 9.0 & 9.0 & 9.0 & 8.7 & 8.7 \\
\hline & 1 hour & ppmv & 35 & - & 20 & 35 & 35 & 13.1 & $13.1^{c} / 13^{d}$ \\
\hline \multirow[t]{2}{*}{ Lead } & $\begin{array}{l}\text { Calendar } \\
\text { quarter }\end{array}$ & $\mu \mathrm{g} / \mathrm{m}^{3}$ & 1.5 & 1.5 & - & 1.5 & 1.5 & - & - \\
\hline & 30 days & $\mu g / \mathrm{m}^{3}$ & - & - & 1.5 & - & - & - & 3 \\
\hline \multirow[t]{3}{*}{ Nitrogen dioxide } & Annual & ppmv & 0.053 & 0.053 & - & 0.05 & 0.05 & 0.05 & 0.05 \\
\hline & 24 hours & ppmv & - & - & - & - & - & 0.10 & 0.062 \\
\hline & 1 hour & ppmv & - & - & 0.25 & - & - & - & - \\
\hline Ozone & 1 hour & ppmv & 0.12 & 0.12 & 0.09 & 0.12 & 0.12 & - & - \\
\hline \multirow{2}{*}{$\begin{array}{l}\text { Particulate matter } \\
\left(\mathrm{PM}_{10}\right)\end{array}$} & Annual & $\mu \mathrm{g} / \mathrm{m}^{3}$ & 50 & 50 & $30^{e}$ & 50 & 50 & - & - \\
\hline & 24 hours & $\mu \mathrm{g} / \mathrm{m}^{3}$ & 150 & 150 & 50 & 150 & 150 & - & - \\
\hline \multirow[t]{4}{*}{ Sulfur dioxide } & Annual & $\mu \mathrm{g} / \mathrm{m}^{3}$ & 80 & - & - & 80 & 60 & 52 & 11 \\
\hline & 24 hours & $\mu \mathrm{g} / \mathrm{m}^{3}$ & 365 & - & 105 & 365 & 260 & 260 & 92 \\
\hline & 3 hours & $\mu \mathrm{g} / \mathrm{m}^{3}$ & - & 1,300 & - & 1,300 & $\cdot 1,300$ & - & - \\
\hline & 1 hour & $\mu \mathrm{g} / \mathrm{m}^{3}$ & - & - & 655 & - & - & - & - \\
\hline \multicolumn{10}{|c|}{ Other Mandated Pollutants } \\
\hline $\begin{array}{l}\text { Arsenic, copper, } \\
\text { and zinc }\end{array}$ & 30 days & $\mu \mathrm{g} / \mathrm{m}^{3}$ & - & - & - & - & - & - & 10 \\
\hline Asbestos & 30 days & $\mu \mathrm{g} / \mathrm{m}^{3}$ & - & - & - & - & - & 0.01 & 0.01 \\
\hline Beryllium & 30 days & $\mu \mathrm{g} / \mathrm{m}^{3}$ & 一 & - & 0.01 & - & - & 0.01 & 0.01 \\
\hline
\end{tabular}


TABLE 2.1 (Cont.)

\begin{tabular}{|c|c|c|c|c|c|c|c|c|c|}
\hline \multirow[b]{3}{*}{ Pollutant } & \multirow{3}{*}{$\begin{array}{c}\text { Averaging } \\
\text { Time }\end{array}$} & \multirow[b]{3}{*}{ Unit } & & & \multicolumn{5}{|c|}{ State Standards } \\
\hline & & & \multicolumn{2}{|c|}{ NAAQS } & \multirow{2}{*}{$\begin{array}{c}\text { California } \\
\text { (LLNL) }\end{array}$} & \multirow{2}{*}{$\begin{array}{c}\text { Nevada } \\
\text { (NTS) }\end{array}$} & \multirow{2}{*}{$\begin{array}{l}\text { Nevada } \\
\text { (NLVF) } \\
\end{array}$} & \multirow{2}{*}{$\begin{array}{c}\text { New } \\
\text { Mexico } \\
\text { (LANL) } \\
\end{array}$} & \multirow{2}{*}{$\begin{array}{c}\text { New } \\
\text { Mexico } \\
\text { (SNL) }\end{array}$} \\
\hline & & & Primary $^{a}$ & Secondary & & & & & \\
\hline Heavy metals & 30 days & $\mu \mathrm{g} / \mathrm{m}^{3}$ & - & - & - & - & - & 10 & 10 \\
\hline Hydrogen sulfide & 1 hour & ppmv & - & - & 0.03 & 0.08 & 0.08 & 0.01 & 0.003 \\
\hline $\begin{array}{l}\text { Nonmethane } \\
\text { hydrocarbons }\end{array}$ & 3 hours & ppmv & - & - & - & - & - & 0.19 & $0.19^{c} / 0.15^{d}$ \\
\hline $\begin{array}{l}\text { Photochemical } \\
\text { oxidants }\end{array}$ & 1 hour & ppmv & $\bar{\cdot}$ & - & - & - & - & 0.06 & 0.01 \\
\hline Soiling index & - & $\begin{array}{l}\text { cohs/ } \\
1,000 \\
\text { linear } \\
\mathrm{ft} \text { of air }\end{array}$ & - & - & - & 一 & - & 0.4 & 0.3 \\
\hline $\begin{array}{l}\text { Suspended } \\
\text { sulfates }\end{array}$ & 24 hours & $\mu \mathrm{g} / \mathrm{m}^{3}$ & - & - & 25 & - & - & - & - \\
\hline $\begin{array}{l}\text { Total reduced } \\
\text { sulfur }\end{array}$ & 30 minutes & ppmv & - & - & - & 一 & - & 0.003 & 0.003 \\
\hline \multirow{4}{*}{$\begin{array}{l}\text { Total suspended } \\
\text { particulates }\end{array}$} & Annual & $\mu \mathrm{g} / \mathrm{m}^{3}$ & 一 & - & - & 一 & - & 60 & 60 \\
\hline & 30 days & $\mu \mathrm{g} / \mathrm{m}^{3}$ & - & - & - & - & $\cdot$ & 90 & 90 \\
\hline & 7 days & $\mu \mathrm{g} / \mathrm{m}^{3}$ & - & - & - & - & - & 110 & 110 \\
\hline & 24 hours & $\mu \mathrm{g} / \mathrm{m}^{3}$ & - & - & - & - & - & 150 & 150 \\
\hline Vinyl chloride & 24 hours & ppmv & - & 一 & 0.10 & - & - & - & - \\
\hline Visibility & - & - & - & - & - & $-f$ & - & - & 一 \\
\hline $\begin{array}{l}\text { Visibility-reducing } \\
\text { particles }\end{array}$ & 8 hours & - & - & - & - $^{g}$ & - & - & - & - \\
\hline
\end{tabular}

See next page for footnotes. 


\section{TABLE 2.1 (Cont.)}

a The NAAQS - other than those for ozone, particulate matter, and those based on annual averages - are not to be exceeded more than once per year. The ozone standard is attained when the expected number of days per year with maximum hourly average concentrations above the standard is less than or equal to 1 . The 24-hour particulate matter standard is attained when the expected number of days with a 24-hour average concentration above the standard is less than or equal to 1 . The annual arithmetic mean particulate matter standard is attained when the expected annual arithmetic mean concentration is less than or equal to the standard.

b $-=$ There is no standard.

c State standard not to be exceeded.

d County standard not to be exceeded more than once per year.

e The California standard is the annual geometric mean; the other standards are the annual arithmetic means.

$\mathfrak{f}$ Present in sufficient amount to produce an extinction coefficient of $0.23 / \mathrm{km}$ due to particles when the relative humidity is less than $70 \%$.

g Present in sufficient amount to reduce the prevailing visibility to less than $50 \mathrm{~km} \mathrm{(30} \mathrm{mi)} \mathrm{when} \mathrm{humidity} \mathrm{is} \mathrm{less} \mathrm{than} 70 \%$.

Sources: 40 CFR Part 50; CARB (1993); NDEP (1988-1992); DBHCC (1993); NMEIB (1981); ABCAQCB (1973). 
TABLE 2.2 Maximum Allowable Prevention of Significant Deterioration (PSD) Concentration Increments

\begin{tabular}{llccc}
\hline & & \multicolumn{3}{c}{ PSD Increment $\left(\mu \mathrm{g} / \mathrm{m}^{3}\right)$} \\
\cline { 3 - 5 } \multicolumn{1}{c}{ Pollutant } & Averaging & Class I & Class II & Class III \\
Time & Area & Area & Area \\
\hline \multirow{2}{*}{ Nitrogen dioxide } & Annual & 2.5 & 25 & 50 \\
Particulate matter $\left(\mathrm{PM}_{10}\right)$ & Annual & 4 & 17 & 34 \\
& 24 hours & \\
Sulfur dioxide & 8 & 30 & 60 \\
& Annual & 2 & 20 & 40 \\
& 24 hours $^{\mathrm{a}}$ & 5 & 91 & 182 \\
& 3 hours $^{\mathrm{a}}$ & 25 & 512 & 700 \\
\hline
\end{tabular}

a Short-term increments are not to be exceeded more than once per year.

Source: 40 CFR 52.21.

\subsubsection{Environmental Impacts}

The estimated air pollutant emissions resulting from NIF construction and operation are discussed in Sections 2.1.2.1 and 2.1.2.2, respectively. Construction emissions were evaluated separately for site-clearing and facility-construction phases. Site clearing would be the first phase of construction and would last, at most, about 2.5 months. Facility construction would follow site clearing and is expected to last a few years, depending on the site-specific construction requirements. Only the potential air quality impact of fugitive dust $\left(\mathrm{PM}_{10}\right)$ from site clearing was evaluated in detail. Although the magnitude of other construction pollutant emissions (from vehicle exhaust) and NIF operating emissions were estimated, the amounts of these other emissions were considered too low to warrant a modeling analysis. Air quality modeling analysis for $\mathrm{PM}_{10}$ emissions from site clearing is included in Section 2.1.2.1.3 under the construction emissions discussion.

\subsubsection{Construction Air Pollutant Emissions}

Construction activities would involve a number of separate dust-generating operations, including site clearing/grubbing, excavation, earthmoving, foundation treatment, building erection, electrical and mechanical installation, road construction, and landscaping. For the purpose of air pollutant emission estimation, construction was divided into two phases: site clearing and facility 
TABLE 2.3 State of California and National Ambient Air Quality Standards

\begin{tabular}{|c|c|c|c|c|}
\hline \multirow[b]{2}{*}{ Pollutant } & \multirow[b]{2}{*}{ Averaging Time } & \multirow[b]{2}{*}{$\begin{array}{l}\text { California } \\
\text { Standards }^{a, b}\end{array}$} & \multicolumn{2}{|c|}{$\mathrm{NAAQS}^{\mathrm{a}, \mathrm{c}}$} \\
\hline & & & Primary & Secondary \\
\hline Ozone & 1 hour & $\begin{array}{c}0.09 \mathrm{ppm} \\
\left(180 \mu \mathrm{g} / \mathrm{m}^{3}\right)\end{array}$ & $\begin{array}{l}0.12 \mathrm{ppm} \\
\left(235 \mu \mathrm{g} / \mathrm{m}^{3}\right)\end{array}$ & $\begin{array}{l}\text { Same as primary } \\
\text { standard }\end{array}$ \\
\hline \multirow[t]{2}{*}{ Carbon monoxide } & 8 hours & $\begin{array}{c}9.0 \mathrm{ppm} \\
\left(10 \mathrm{mg} / \mathrm{m}^{3}\right)\end{array}$ & $\begin{array}{l}9.0 \mathrm{ppm} \\
\left(10 \mathrm{mg} / \mathrm{m}^{3}\right)\end{array}$ & $-d$ \\
\hline & 1 hour & $\begin{array}{c}20 \mathrm{ppm} \\
\left(23 \mathrm{mg} / \mathrm{m}^{3}\right)\end{array}$ & $\begin{array}{l}35 \mathrm{ppm} \\
\left(40 \mathrm{mg} / \mathrm{m}^{3}\right)\end{array}$ & - \\
\hline \multirow[t]{2}{*}{ Nitrogen dioxide } & Annual average & - & $\begin{array}{l}0.053 \mathrm{ppm} \\
\left(100 \mu \mathrm{g} / \mathrm{m}^{3}\right)\end{array}$ & $\begin{array}{l}\text { Same as primary } \\
\text { standard }\end{array}$ \\
\hline & 1 hour & $\begin{array}{c}0.25 \mathrm{ppm} \\
\left(470 \mu \mathrm{g} / \mathrm{m}^{3}\right)\end{array}$ & - & - \\
\hline \multirow[t]{4}{*}{ Sulfur dioxide } & Annual average & - & $80 \mu \mathrm{g} / \mathrm{m}^{3}$ & - \\
\hline & 24 hours & $\begin{array}{c}0.04 \mathrm{ppm} \\
\left(105 \mu \mathrm{g} / \mathrm{m}^{3}\right)\end{array}$ & $\begin{array}{l}365 \mu \mathrm{g} / \mathrm{m}^{3} \\
(0.14 \mathrm{ppm})\end{array}$ & - \\
\hline & 3 hours & - & - & $\begin{array}{l}1,300 \mu \mathrm{g} / \mathrm{m}^{3} \\
(0.5 \mathrm{ppm})\end{array}$ \\
\hline & 1 hour & $\begin{array}{c}0.25 \mathrm{ppm} \\
\left(655 \mu \mathrm{g} / \mathrm{m}^{3}\right)\end{array}$ & 一 & - \\
\hline \multirow[t]{3}{*}{$\begin{array}{l}\text { Particulate matter } \\
\left(\mathrm{PM}_{10}\right)\end{array}$} & $\begin{array}{l}\text { Annual geometric } \\
\text { mean }\end{array}$ & $30 \mu \mathrm{g} / \mathrm{m}^{3}$ & - & - \\
\hline & 24 hours & $50 \mu \mathrm{g} / \mathrm{m}^{3}$ & $150 \mu \mathrm{g} / \mathrm{m}^{3}$ & $\begin{array}{l}\text { Same as primary } \\
\text { standard }\end{array}$ \\
\hline & $\begin{array}{l}\text { Annual arithmetic } \\
\text { mean }\end{array}$ & - & $50 \mu \mathrm{g} / \mathrm{m}^{3}$ & $\begin{array}{l}\text { Same as primary } \\
\text { standard }\end{array}$ \\
\hline Sulfates & 24 hours & $25 \mu \mathrm{g} / \mathrm{m}^{3}$ & - & - \\
\hline \multirow[t]{2}{*}{ Lead } & 30 day average & $1.5 \mu \mathrm{g} / \mathrm{m}^{3}$ & 一 & - \\
\hline & Calendar quarter & - & $1.5 \mu \mathrm{g} / \mathrm{m}^{3}$ & $\begin{array}{l}\text { Same as primary } \\
\text { standard }\end{array}$ \\
\hline Hydrogen sulfide & 1 hour & $\begin{array}{c}0.03 \mathrm{ppm} \\
\left(42 \mu \mathrm{g} / \mathrm{m}^{3}\right)\end{array}$ & - & - \\
\hline $\begin{array}{l}\text { Vinyl chloride } \\
\text { (chloroethene) }\end{array}$ & 24 hours & $\begin{array}{c}0.10 \mathrm{ppm} \\
\left(26 \mu \mathrm{g} / \mathrm{m}^{3}\right)\end{array}$ & - & - \\
\hline
\end{tabular}


TABLE 2.3 (Cont.)

\begin{tabular}{lllll} 
Pollutant & Averaging Time & \multicolumn{1}{c}{$\begin{array}{c}\text { Nalifornia } \\
\text { Standards }\end{array}$} & Primary & Secondary \\
\hline $\begin{array}{l}\text { Visibility-reducing } \\
\text { particles }\end{array}$ & $\begin{array}{l}8 \text { hours (10 a.m. to } \\
6 \text { p.m., PST) }\end{array}$ & $\begin{array}{l}\text { "In sufficient amount to } \\
\text { produce an extinction } \\
\text { coefficient of 0.23/km due } \\
\text { to particles when the } \\
\text { relative humidity is less } \\
\text { than 70 percent. Measure- } \\
\text { ment in accordance with } \\
\text { ARB Method V." }\end{array}$ \\
\hline
\end{tabular}

a Concentration expressed first in units in which it was promulgated. Equivalent units given in parenthesis are based upon a reference temperature of $25^{\circ} \mathrm{C}$ and a reference pressure of $760 \mathrm{~mm}$ of mercury. All measurements of air quality are to be corrected to a reference temperature of $25^{\circ} \mathrm{C}$ and a reference pressure of $760 \mathrm{~mm}$ of mercury; $\mathrm{ppm}$ in this table refers to $\mathrm{ppm}$ by volume or micromoles of pollutant per mole of gas.

b California standards for ozone, carbon monoxide, sulfur dioxide (1 hour and 24-hour), $\mathrm{NO}_{2}, \mathrm{PM}_{10}$ particulate matter, and visibility-reducing particles are values that are not to be exceeded. The standards for sulfates, lead, hydrogen sulfide, and vinyl chloride are not to be equaled or exceeded.

c The NAAQS - other than ozone and those based on annual averages or annual arithmetic means - are not to be exceeded more than once a year. The ozone standard is attained when the expected number of days per calendar year with maximum hourly average concentrations above the standard is equal to or less than 1 .

d $-=$ there is no standard.

Source: CARB (1993).

construction. As the first phase of construction, site clearing would involve removal and clearing of all surface structures and growth from the site and leveling of the terrain, followed by earthmoving, including excavation and placement of earth fill. Facility construction would involve all the construction phases after site clearing.

The number of days, types of equipment, and daily construction vehicle fuel consumption specified for site clearing at LLNL were used as the basis for estimating project-related site clearing air pollutant emissions (Foley 1995). These data based on daily site clearing activity at LLNL were also used to estimate the number of days to complete the site clearing for other candidate sites by using site-specific construction areas as a scaling factor. The time needed for site clearing and facility construction for the first year of construction and total construction area that would be disturbed at each site are summarized in Table 2.9. The estimated time to perform site clearing varies among sites from two weeks to nearly 2.5 months as a function of construction site area. Facility construction is estimated to take place over a five-year period (LLNL 1995b). 
TABLE 2.4 Livermore Old First Street Ambient Air Monitoring Station Criteria Pollutant Monitoring Data for 1993

\begin{tabular}{|c|c|c|c|}
\hline \multirow[b]{2}{*}{ Pollutant } & \multirow[b]{2}{*}{ Averaging Time } & \multicolumn{2}{|c|}{ Standard Exceeded } \\
\hline & & California & National \\
\hline Ozone & 1 hour & 21 occurrences & 1 occurrence \\
\hline \multirow[t]{2}{*}{ Carbon monoxide } & 8 hours & No occurrences & No occurrences \\
\hline & 1 hour & No occurrences & No occurrences \\
\hline \multirow[t]{2}{*}{ Nitrogen dioxide } & Annual average & $-{ }^{a}$ & No occurrences \\
\hline & 1 hour & No occurrences & - \\
\hline \multirow{3}{*}{$\begin{array}{l}\text { Particulate matter } \\
\left(\mathrm{PM}_{10}\right)\end{array}$} & Annual geometric mean & No occurrences & - \\
\hline & 24 hours & 3 occurrences & No occurrences \\
\hline & Annual arithmetic mean & - & No occurrences \\
\hline \multirow[t]{2}{*}{ Lead } & 30 day average & No occurrences & 一 \\
\hline & Calendar quarter & - & No occurrences \\
\hline
\end{tabular}

a $-=$ no ambient air quality standard.

Source: CARB (1993).

Air pollutant emissions that would be expected during the construction period include fugitive $\mathrm{PM}_{10}$ emissions from soil disturbance and, to a lesser degree, exhaust emissions from construction vehicles. Because of the high degree of soil disturbance, $\mathrm{PM}_{10}$ emission rates for site clearing would be much higher than those for facility construction. Therefore, annual emissions are estimated for the first year of construction, with separate analysis of site clearing and facility construction phases. Estimated total annual emissions from site clearing and facility construction stemming from vehicle exhaust and fugitive dust are summarized in Table 2.10 for each of the five NIF candidate sites. Air pollutant emission estimates from construction vehicle exhaust and $\mathrm{PM}_{10}$ fugitive dust are described in Sections 2.1.2.1.1 and 2.1.2.1.2, respectively. Subsequent years of construction would not involve site clearing, and annual emissions are estimated to be lower than those for the first year.

\subsection{Construction Vehicle Exhaust Emissions}

\section{Site Clearing}

The anticipated construction vehicle exhaust emissions for site clearing activities are summarized for each construction site in Table 2.11. Annual air pollutant emissions are summed for 
TABLE 2.5 State of Nevada and National Ambient Air Quality Standards

\begin{tabular}{|c|c|c|c|c|}
\hline \multirow[b]{2}{*}{ Pollutant } & \multirow[b]{2}{*}{ Averaging Time } & \multirow[b]{2}{*}{$\begin{array}{c}\text { Nevada } \\
\text { Standards }\end{array}$} & \multicolumn{2}{|c|}{ National Standards ${ }^{\mathrm{a}, \mathrm{c}}$} \\
\hline & & & Primary & Secondary \\
\hline Ozone & 1 hour & $\begin{array}{l}235 \mu \mathrm{g} / \mathrm{m}^{3} \\
(0.12 \mathrm{ppm})\end{array}$ & $\begin{array}{l}0.12 \mathrm{ppm} \\
\left(235 \mu \mathrm{g} / \mathrm{m}^{3}\right)\end{array}$ & $\begin{array}{l}\text { Same as primary } \\
\text { standard }\end{array}$ \\
\hline Ozone - Lake Tahoe & 1 hour & $\begin{array}{l}195 \mu \mathrm{g} / \mathrm{m}^{3} \\
(0.10 \mathrm{ppm})\end{array}$ & $\begin{array}{l}0.12 \mathrm{ppm} \\
\left(235 \mu \mathrm{g} / \mathrm{m}^{3}\right)\end{array}$ & $\begin{array}{l}\text { Same as primary } \\
\text { standard }\end{array}$ \\
\hline $\begin{array}{l}\text { Carbon monoxide less than } \\
5,000 \mathrm{ft} \text { above mean sea level }\end{array}$ & 8 hours & $\begin{array}{l}10,000 \mu \mathrm{g} / \mathrm{m}^{3} \\
(9.0 \mathrm{ppm})\end{array}$ & $\begin{array}{l}9.0 \mathrm{ppm} \\
\left(10 \mathrm{mg} / \mathrm{m}^{3}\right)\end{array}$ & $-^{d}$ \\
\hline $\begin{array}{l}\text { Carbon monoxide at or } \\
\text { greater than } 5,000 \text { feet } \\
\text { above mean sea level }\end{array}$ & 8 hours & $\begin{array}{l}6,670 \mu \mathrm{g} / \mathrm{m}^{3} \\
(6.0 \mathrm{ppm})\end{array}$ & $\begin{array}{l}9.0 \mathrm{ppm} \\
\left(10 \mathrm{mg} / \mathrm{m}^{3}\right)\end{array}$ & - \\
\hline $\begin{array}{l}\text { Carbon monoxide at any } \\
\text { elevation }\end{array}$ & 1 hour & $\begin{array}{l}40,000 \mu \mathrm{g} / \mathrm{m}^{3} \\
(35 \mathrm{ppm})\end{array}$ & $\begin{array}{l}40 \mathrm{mg} / \mathrm{m}^{3} \\
(35 \mathrm{ppm})\end{array}$ & - \\
\hline Nitrogen dioxide & Annual average & $\begin{array}{l}100 \mu \mathrm{g} / \mathrm{m}^{3} \\
(0.05 \mathrm{ppm})\end{array}$ & $\begin{array}{l}100 \mu \mathrm{g} / \mathrm{m}^{3} \\
(0.05 \mathrm{ppm})\end{array}$ & $\begin{array}{l}\text { Same as primary } \\
\text { standard }\end{array}$ \\
\hline \multirow[t]{3}{*}{ Sulfur dioxide } & Annual average & $\begin{array}{l}80 \mu \mathrm{g} / \mathrm{m}^{3} \\
(0.03 \mathrm{ppm})\end{array}$ & $\begin{array}{l}80 \mu \mathrm{g} / \mathrm{m}^{3} \\
(0.03 \mathrm{ppm})\end{array}$ & - \\
\hline & 24 hours & $\begin{array}{l}365 \mu \mathrm{g} / \mathrm{m}^{3} \\
(0.14 \mathrm{ppm})\end{array}$ & $\begin{array}{l}365 \mu \mathrm{g} / \mathrm{m}^{3} \\
(0.14 \mathrm{ppm})\end{array}$ & - \\
\hline & 3 hours & $\begin{array}{l}1,300 \mu \mathrm{g} / \mathrm{m}^{3} \\
(0.5 \mathrm{ppm})\end{array}$ & - & $\begin{array}{l}1,300 \mu \mathrm{g} / \mathrm{m}^{3} \\
(0.5 \mathrm{ppm})\end{array}$ \\
\hline \multirow[t]{2}{*}{ Particulate matter $\left(\mathrm{PM}_{10}\right)$} & $\begin{array}{l}\text { Annual arithmetic } \\
\text { mean }\end{array}$ & $50 \mu \mathrm{g} / \mathrm{m}^{3}$ & $50 \mu \mathrm{g} / \mathrm{m}^{3}$ & $\begin{array}{l}\text { Same as primary } \\
\text { standard }\end{array}$ \\
\hline & 24 hours & $150 \mu \mathrm{g} / \mathrm{m}^{3}$ & $150 \mu \mathrm{g} / \mathrm{m}^{3}$ & $\begin{array}{l}\text { Same as primary } \\
\text { standard }\end{array}$ \\
\hline \multirow[t]{2}{*}{ Lead } & 30 day average & $1.5 \mu \mathrm{g} / \mathrm{m}^{3}$ & - & - \\
\hline & Calendar quarter & - & $1.5 \mu \mathrm{g} / \mathrm{m}^{3}$ & $\begin{array}{l}\text { Same as primary } \\
\text { standard }\end{array}$ \\
\hline Hydrogen sulfide & 1 hour & $\begin{array}{l}112 \mu \mathrm{g} / \mathrm{m}^{3(e)} \\
(0.08 \mathrm{ppm})\end{array}$ & & \\
\hline Visibility-reducing particles & Observation & $-^{f}$ & & \\
\hline
\end{tabular}

a Concentration expressed first in units in which it was promulgated. Equivalent units given in parenthesis are based upon a reference temperature of $25^{\circ} \mathrm{C}$ and a reference pressure of $760 \mathrm{~mm}$ of mercury. All measurements of air quality are to be corrected to a reference temperature of $25^{\circ} \mathrm{C}$ and a reference pressure of $760 \mathrm{~mm}$ of mercury; ppm in this table refers to ppm by volume, or micromoles of pollutant per mole of gas.

b These standards must not be exceeded in areas where the general public has access.

c The AAQS - other than ozone and those based on annual averages or annual arithmetic means - are not to be exceeded more than once a year. The ozone standard is attained when the expected number of days per calendar year with maximum hourly average concentrations above the standard is equal to or less than 1 .

d $-=$ there is no standard.

c The ambient air quality standard for hydrogen sulfide does not include naturally occurring background concentrations.

f Present in sufficient amount to reduce the prevailing visibility to less than $50 \mathrm{~km}$ when humidity is less than 70 ,percent. For the purposes of this section, prevailing visibility means the greatest visibility that is attained or surpassed around at least half of the horizon circle but not necessarily in continuous sectors.

Source: NDEP (1988-1992). 
TABLE 2.6 Clark County, Nevada, and National Ambient Air Quality Standards

\begin{tabular}{|c|c|c|c|c|}
\hline \multirow[b]{2}{*}{ Pollutant } & \multirow[b]{2}{*}{ Averaging Time } & \multirow[b]{2}{*}{$\begin{array}{l}\text { Clark County } \\
\text { Standards }\end{array}$} & \multicolumn{2}{|r|}{$N_{A A Q S}{ }^{a, b}$} \\
\hline & & & Primary & Secondary \\
\hline Ozone & 1 hour & $\begin{array}{l}235 \mu \mathrm{g} / \mathrm{m}^{3} \\
(0.12 \mathrm{ppm})\end{array}$ & $\begin{array}{l}0.12 \mathrm{ppm} \\
\left(235 \mu \mathrm{g} / \mathrm{m}^{3}\right)\end{array}$ & Same as primary standard \\
\hline \multirow[t]{2}{*}{ Carbon monoxide } & 8 hours & $\begin{array}{l}10 \mathrm{mg} / \mathrm{m}^{3} \\
(9.0 \mathrm{ppm})\end{array}$ & $\begin{array}{l}9.0 \mathrm{ppm} \\
\left(10 \mathrm{mg} / \mathrm{m}^{3}\right)\end{array}$ & $-^{c}$ \\
\hline & 1 hour & $\begin{array}{l}40 \mathrm{mg} / \mathrm{m}^{3} \\
(35 \mathrm{ppm})\end{array}$ & $\begin{array}{l}35 \mathrm{ppm} \\
\left(40 \mathrm{mg} / \mathrm{m}^{3}\right)\end{array}$ & - \\
\hline Nitrogen dioxide & Annual average & $\begin{array}{l}100 \mu \mathrm{g} / \mathrm{m}^{3} \\
(0.053 \mathrm{ppm})\end{array}$ & $\begin{array}{l}0.053 \mathrm{ppm} \\
\left(100 \mu \mathrm{g} / \mathrm{m}^{3}\right)\end{array}$ & Same as primary standard \\
\hline \multirow[t]{3}{*}{ Sulfur dioxide } & Annual average & $\begin{array}{l}60 \mu \mathrm{g} / \mathrm{m}^{3} \\
(0.02 \mathrm{ppm})\end{array}$ & $\begin{array}{l}80 \mu \mathrm{g} / \mathrm{m}^{3} \\
(0.03 \mathrm{ppm})\end{array}$ & 一 \\
\hline & 24 hours & $\begin{array}{l}260 \mu \mathrm{g} / \mathrm{m}^{3} \\
(0.1 \mathrm{ppm})\end{array}$ & $\begin{array}{l}365 \mu \mathrm{g} / \mathrm{m}^{3} \\
(0.14 \mathrm{ppm})\end{array}$ & - \\
\hline & 3 hours & $\begin{array}{l}1,300 \mu \mathrm{g} / \mathrm{m}^{3} \\
(0.5 \mathrm{ppm})\end{array}$ & - & $\begin{array}{l}1,300 \mu \mathrm{g} / \mathrm{m}^{3} \\
(0.5 \mathrm{ppm})\end{array}$ \\
\hline Particulate matter & Annual arithmetic mean & $50 \mu \mathrm{g} / \mathrm{m}^{3}$ & $50 \mu \mathrm{g} / \mathrm{m}^{3}$ & Same as primary standard \\
\hline$\left(\mathrm{PM}_{10}\right)$ & 24 hours & $150 \mu \mathrm{g} / \mathrm{m}^{3}$ & $150 \mu \mathrm{g} / \mathrm{m}^{3}$ & Same as primary standard \\
\hline Lead & Calendar quarter & - & $1.5 \mu \mathrm{g} / \mathrm{m}^{3}$ & Same as primary standard \\
\hline
\end{tabular}

a The AAQS - other than ozone and those based on annual averages or annual arithmetic means - are not to be exceeded more than once a year. The ozone standard is attained when the expected number of days per calendar year with maximum hourly average concentrations above the standard is equal to or less than 1 .

b Concentration expressed first in units in which it was promulgated. Equivalent units given in parenthesis are based upon a reference temperature of $25^{\circ} \mathrm{C}$ and a reference pressure of $760 \mathrm{~mm}$ of mercury. All measurements of air quality are to be corrected to a reference temperature of $25^{\circ} \mathrm{C}$ and a reference pressure of $760 \mathrm{~mm}$ of mercury; ppm in this table refers to ppm by volume, or micromoles of pollutant per mole of gas.

c $-=$ there is no standard.

Source: DBHCC (1993).

each site on the basis of the estimated time to complete site clearing. LLNL provided information on site-clearing equipment, diesel fuel consumption for each piece of construction equipment (Foley 1995), and time to complete site clearing. Vehicle exhaust emissions were computed on the basis of this information and use of EPA emission factors (see Table 2.12). These data were also used to compute air pollutant emissions for the other candidate sites. It was assumed that the daily siteclearing activity at the other candidate sites would be the same as at LLNL, but that the time to complete site clearing would vary depending on the size of the candidate site construction area relative to the size of the LLNL construction site area. (Table 2.9 lists the size of the construction site areas for each candidate site.) 
TABLE 2.7 1994 Ambient Air Concentrations in Vicinity of North Las Vegas Facility

\begin{tabular}{|c|c|c|c|c|c|c|c|}
\hline \multirow[b]{2}{*}{ Monitoring Station } & \multirow{2}{*}{$\begin{array}{l}\text { Distance from } \\
\text { NLVF NIF } \\
\text { Location } \\
(\mathrm{km})\end{array}$} & \multicolumn{2}{|c|}{$\begin{array}{c}\text { Carbon Monoxide } \\
\text { (ppmv) }\end{array}$} & \multirow{2}{*}{$\begin{array}{c}\text { Nitrogen } \\
\text { Dioxide } \\
\text { (ppmv), } \\
\text { Annual }\end{array}$} & \multirow{2}{*}{$\begin{array}{c}\text { Ozone } \\
\text { (ppmv), } \\
\text { Highest } \\
\text { 1-hour }\end{array}$} & \multicolumn{2}{|c|}{$\begin{array}{l}\mathrm{PM}_{10} \\
\left(\mu \mathrm{g} / \mathrm{m}^{3}\right)\end{array}$} \\
\hline & & $\begin{array}{l}\text { Highest } \\
\text { 8-hour }\end{array}$ & $\begin{array}{l}\text { Highest } \\
\text { 1-hour }\end{array}$ & & & Annual & $\begin{array}{l}\text { Highest } \\
\text { 24-hour }\end{array}$ \\
\hline McDaniel & 1.9 & $-^{a}$ & - & - & - & $47^{b}$ & $117^{b}$ \\
\hline City Center Gaseous (West) & 3.9 & $7.54^{\mathrm{b}}$ & $11.75^{b}$ & - & 0.098 & - & $129^{c}$ \\
\hline City Center (Bonanza) & 4 & - & - & - & - & 35 & 89 \\
\hline Bemis (Craig Rd.) & 4.4 & 一 & - & 一 & 0.102 & 48 & 155 \\
\hline Health District (Shadow Ln.) & 5.7 & 7.45 & 10.7 & - & 0.100 & - & - \\
\hline LV Fire Sta. 2 & 5.8 & 11.71 & 15.05 & - & - & - & - \\
\hline E. Charleston & 5.8 & 10.92 & 15.29 & $0.028^{b}$ & - & - & - \\
\hline Maycliff & 7.8 & 9.23 & 11.80 & - & - & 40 & 200 \\
\hline McMillan (Walt Lott) & 9.4 & - & - & - & - & 28 & 66 \\
\hline Wengert & 9.8 & 一 & - & - & - & 47 & 122 \\
\hline Flamingo & 9.9 & 7.74 & 9.16 & - & 0.094 & - & $114^{c}$ \\
\hline Winterwood & 10 & 8.35 & 9.98 & - & 0.103 & - & - \\
\hline Diskin (Ravenwood Dr.) & 13.6 & - & - & - & - & 33 & 116 \\
\hline Paul Meyer & 15.5 & - & - & - & - & 一 & $98^{\mathrm{c}}$ \\
\hline Pittman & 19.1 & - & - & - & - & 一 & $141^{c}$ \\
\hline Frias & 21.2 & - & - & - & - & 21 & 46 \\
\hline Powerline & 21.3 & 3.43 & 10.40 & - & 0.097 & 46 & 138 \\
\hline Burkholder & 21.5 & - & - & - & - & 20 & 46 \\
\hline Boulder City & 45 & - & 一 & - & - & - & $22^{c}$ \\
\hline Jean & 60 & - & - & - & - & - & $32^{c}$ \\
\hline
\end{tabular}

a $-=$ no data available.

b Data from station nearest the NLVF NIF location.

c Less than a full year of data; highest concentration may be underestimated.

Source: Taipale (1995).

\section{Facility Construction}

Facility construction would involve all the construction phases after site clearing. Included would be such major activities as excavating foundations, pouring concrete, and erecting buildings. Facility construction is projected to take place over a five-year period. Fugitive dust $\left(\mathrm{PM}_{10}\right)$ emissions during facility construction are discussed in Section 2.1.2.1.2. Air pollutant emissions other than $\mathrm{PM}_{10}$ are expected to be primarily from use of construction equipment and vehicle exhaust. Annual vehicle exhaust emissions have been estimated by LLNL (LLNL 1995b) and are included in Table 2.13. 
TABLE 2.8 1993 Ambient Air Concentrations in Vicinity of Sandia National Laboratories

\begin{tabular}{|c|c|c|c|c|c|c|c|c|c|c|}
\hline \multirow{2}{*}{$\begin{array}{c}\text { Stare } \\
\text { Station } \\
\text { ID }\end{array}$} & \multirow{2}{*}{$\begin{array}{l}\text { Distance } \\
\text { from } \\
\text { NIF } \\
\text { Location } \\
(\mathrm{km})\end{array}$} & \multicolumn{3}{|c|}{$\begin{array}{l}\text { Carbon Monoxide } \\
\text { (ppmv) }\end{array}$} & \multicolumn{2}{|c|}{$\begin{array}{l}\text { Nitrogen Dioxide } \\
\text { (ppmv) }\end{array}$} & \multicolumn{2}{|c|}{$\begin{array}{l}\text { Ozone } \\
\text { (ppmv) }\end{array}$} & \multicolumn{2}{|c|}{$\begin{array}{l}\text { Particulate Matter } \\
\left(\mathrm{PM}_{10}\right)(\mu \mathrm{g} / \mathrm{m})\end{array}$} \\
\hline & & $\begin{array}{l}\text { Highest } \\
\text { 8-hour }\end{array}$ & $\begin{array}{l}\text { Highest } \\
\text { 1-hour }\end{array}$ & $\begin{array}{l}\text { Highest } \\
\text { 1-hour }\end{array}$ & $\begin{array}{l}\text { Highest } \\
\text { 24-hour }\end{array}$ & Annual & $\begin{array}{l}\text { Highest } \\
\text { 1-hour }\end{array}$ & $\begin{array}{l}\text { Highest } \\
1 \text {-hour }\end{array}$ & $\begin{array}{l}\text { Highest } \\
\text { 24-hour }\end{array}$ & Annual \\
\hline 2ZE & 7.8 & $8.0^{2}$ & $10.0^{\mathrm{a}}$ & $10.0^{\mathrm{a}}$ & $-b$ & - & $0.087^{a}$ & $0.084^{a}$ & $40^{2}$ & $17^{\mathrm{a}}$ \\
\hline $2 \mathrm{ZK}$ & 8.8 & 9.0 & 12.0 & 12.0 & - & - & - & - & 53 & 27 \\
\hline $2 \mathrm{ZM}$ & 11 & 5.8 & 10.0 & 9.0 & $0.054^{\mathrm{a}}$ & $0.024^{\mathrm{a}}$ & 0.088 & 0.088 & 58 & 26 \\
\hline $2 Z 0$ & 11 & - & - & - & - & - & - & - & 65 & 28 \\
\hline $2 \mathrm{R}$ & 13 & 3.9 & 7.0 & 7.0 & - & - & 0.084 & 0.080 & 69 & 35 \\
\hline $2 G$ & 15 & - & - & - & - & - & - & - & 38 & 21 \\
\hline $2 \mathrm{ZF}$ & 17 & - & - & - & - & - & 0.085 & 0.080 & - & - \\
\hline $2 \mathrm{ZH}$ & 18 & - & - & - & - & - & 0.085 & 0.080 & 86 & 25 \\
\hline $2 Z L$ & 20 & 2.1 & 5.0 & 5.0 & - & - & - & - & 47 & 22 \\
\hline $2 \mathrm{ZN}$ & 20 & 5.1 & 9.0 & 9.0 & - & - & - & - & 36 & 19 \\
\hline $2 Z Q$ & 25 & 2.0 & 5.7 & 4.1 & - & - & 0.090 & 0.086 & - & - \\
\hline $2 Z P$ & 28 & - & - & - & - & - & 0.078 & 0.072 & - & - \\
\hline $2 U$ & 29 & - & - & - & - & - & - & - & 63 & 28 \\
\hline 2ZJ & 29 & - & - & - & - & - & 0.082 & 0.080 & - & - \\
\hline
\end{tabular}

a Data from station nearest the SNL NIF location.

b $-=$ no data available.

Source: NMAQB (1994).

TABLE 2.9 Estimated Number of Months Required for Site Clearing and Facility Construction for the First Year

\begin{tabular}{|c|c|c|c|}
\hline \multirow[b]{2}{*}{ Site } & \multirow[b]{2}{*}{$\begin{array}{l}\text { Area } \\
\text { (ha) }\end{array}$} & \multicolumn{2}{|c|}{$\begin{array}{l}\text { Estimated Duration } \\
\text { (months) }\end{array}$} \\
\hline & & $\begin{array}{c}\text { Site } \\
\text { Clearing }\end{array}$ & $\begin{array}{c}\text { Facility } \\
\text { Construction }\end{array}$ \\
\hline $\operatorname{LLNL}^{\mathrm{a}}$ & 7.5 & 1.0 & 11.0 \\
\hline $\mathrm{LANL}^{\mathrm{b}}$ & 4.0 & 0.5 & 11.5 \\
\hline $\operatorname{NTS}^{c}$ & 18.2 & 2.4 & 9.6 \\
\hline$N_{L V F}{ }^{d}$ & 3.3 & 0.4 & 11.6 \\
\hline SNL ${ }^{e}$ & 9.7 & 1.3 & 10.7 \\
\hline \multicolumn{4}{|c|}{ a LLNL (1994). } \\
\hline \multicolumn{4}{|c|}{ b Richardson (1995). } \\
\hline \multicolumn{4}{|c|}{ c White (1995a). } \\
\hline \multicolumn{4}{|c|}{ d Lazaroff (1995). } \\
\hline e Whee & & & \\
\hline
\end{tabular}


TABLE 2.10 Estimated Construction Activity Air Pollutant Emission Summary for Candidate Sites

\begin{tabular}{|c|c|c|c|}
\hline \multirow[b]{2}{*}{ Pollutant } & \multicolumn{3}{|c|}{ Estimated Construction Activity Emissions (kg/yr) } \\
\hline & $\begin{array}{c}\text { Site } \\
\text { Clearing }\end{array}$ & $\begin{array}{c}\text { Facility } \\
\text { Construction }\end{array}$ & Total \\
\hline \multicolumn{4}{|l|}{ LLNL } \\
\hline $\mathrm{PM}_{10}$ & 4,138 & 10,011 & 14,149 \\
\hline VOCs & 406 & 32 & 438 \\
\hline $\mathrm{CO}$ & 1,104 & 127 & 1,231 \\
\hline $\mathrm{NO}_{2}$ & 3,719 & 35 & 3,754 \\
\hline $\mathrm{SO}_{2}$ & 387 & 35 & 422 \\
\hline Lead & Negligible & Negligible & Negligible \\
\hline \multicolumn{4}{|l|}{ LANL } \\
\hline $\mathrm{PM}_{10}$ & 2,171 & 5,656 & 7,827 \\
\hline VOCs & 216 & 32 & 249 \\
\hline $\mathrm{CO}$ & 589 & 127 & 716 \\
\hline $\mathrm{NO}_{2}$ & 1,984 & 35 & 2,019 \\
\hline $\mathrm{SO}_{2}$ & 206 & 35 & 241 \\
\hline Lead & Negligible & Negligible & Negligible \\
\hline \multicolumn{4}{|l|}{ NTS } \\
\hline $\mathrm{PM}_{10}$ & 10,415 & 21,170 & 31,584 \\
\hline VOCs & 988 & 32 & 1,020 \\
\hline $\mathrm{CO}$ & 2,686 & 127 & 2,813 \\
\hline $\mathrm{NO}_{2}$ & 9,052 & 35 & 9,087 \\
\hline $\mathrm{SO}_{2}$ & 941 & 35 & 976 \\
\hline Lead & Negligible & Negligible & Negligible \\
\hline \multicolumn{4}{|l|}{ NLVF } \\
\hline $\mathrm{PM}_{10}$ & 1,866 & 4,658 & 6,524 \\
\hline VOCs & 176 & 32 & 208 \\
\hline $\mathrm{CO}$ & 478 & 1,277 & 1,755 \\
\hline $\mathrm{NO}_{2}$ & 1,611 & 35 & 1,648 \\
\hline $\mathrm{SO}_{2}$ & 168 & 35 & 203 \\
\hline Lead & Negligible & Negligible & Negligible \\
\hline \multicolumn{4}{|l|}{ SNL } \\
\hline $\mathrm{PM}_{10}$ & 5,235 & 12,642 & 17,876 \\
\hline VOCs & 527 & 32 & 559 \\
\hline $\mathrm{CO}$ & 1,435 & 127 & 1,562 \\
\hline $\mathrm{NO}_{2}$ & 4,836 & 35 & 4,871 \\
\hline $\mathrm{SO}_{2}$ & 502 & 35 & 537 \\
\hline Lead & Negligible & Negligible & Negligible \\
\hline
\end{tabular}


TABLE 2.11 Estimated Site-Clearing Construction Vehicle Exhaust Emissions for Each Candidate Site ${ }^{\mathrm{a}}$

\begin{tabular}{|c|c|c|c|c|c|c|}
\hline \multirow{2}{*}{$\begin{array}{c}\text { Site-Clearing } \\
\text { Equipment Category }\end{array}$} & \multirow{2}{*}{$\begin{array}{c}\text { Diesel Fuel } \\
\text { Consumption } \\
\text { (L) }\end{array}$} & \multicolumn{5}{|c|}{$\begin{array}{c}\text { Pollutant Emissions } \\
(\mathrm{kg} / 30 \text { days })\end{array}$} \\
\hline & & $\mathrm{PM}_{10}$ & VOCs & $\mathrm{CO}$ & $\mathrm{NO}_{2}$ & $\mathrm{SO}_{2}$ \\
\hline \multicolumn{7}{|l|}{ LLNL } \\
\hline Water tankers & 7,268 & 15 & 12 & 108 & 249 & 27 \\
\hline Bottom loaders/dump graders & 54,510 & 191 & 282 & 645 & 2,098 & 204 \\
\hline Bulldozers & 27,255 & 83 & 90 & 256 & 930 & 102 \\
\hline Graders & 14,536 & 39 & 22 & 95 & 442 & 54 \\
\hline Totals & 103,569 & 328 & 406 & 1,104 & 3,719 & 387 \\
\hline \multicolumn{7}{|l|}{ LANL } \\
\hline Water tankers & 3,876 & 8 & 6 & 57 & 133 & 15 \\
\hline Bottom loaders/dump graders & 29,072 & 102 & 150 & 344 & 1,119 & 108 \\
\hline Bulldozers & 14,536 & 44 & 48 & 137 & 496 & 54 \\
\hline Graders & 7,752 & 21 & 12 & 51 & 236 & 29 \\
\hline Totals & 55,237 & 175 & 216 & 589 & 1,984 & 206 \\
\hline \multicolumn{7}{|l|}{ NTS } \\
\hline Water tankers & 17,685 & 38 & 28 & 262 & 606 & 66 \\
\hline Bottom loaders/dump graders & 132,640 & 466 & 686 & 1,568 & 5,106 & 496 \\
\hline Bulldozers & 66,320 & 201 & 220 & 624 & 2,264 & 247 \\
\hline Graders & 35,371 & 94 & 54 & 232 & 1,076 & 132 \\
\hline Totals & 252,196 & 799 & 988 & 2,686 & 9,052 & 941 \\
\hline \multicolumn{7}{|l|}{ NLVF } \\
\hline Water tankers & 3,149 & 7 & 5 & 47 & 108 & 12 \\
\hline Bottom loaders/dump graders & 23,621 & 83 & 122 & 279 & 909 & 88 \\
\hline Bulldozers & 11,810 & 36 & 39 & 111 & 403 & 44 \\
\hline Graders & 6,299 & 17 & 10 & 41 & 191 & 24 \\
\hline Totals & 44,880 & 143 & 176 & 478 & 1,611 & 168 \\
\hline \multicolumn{7}{|l|}{ SNL } \\
\hline Water tankers & 9,448 & 20 & 15 & 140 & 324 & 35 \\
\hline Bottom loaders/dump graders & 70,863 & 249 & 366 & 838 & 2,727 & 265 \\
\hline Bulldozers & 35,431 & 108 & 117 & 333 & 1,210 & 132 \\
\hline Graders & 18,897 & 50 & 29 & 124 & 575 & 70 \\
\hline Totals & 134,639 & 427 & 527 & 1,435 & 4,836 & 502 \\
\hline
\end{tabular}

a Based on site-clearing equipment daily fuel consumption (Foley 1995) and 30 days of site clearing for LLNL, 16 days for LANL, 73 days for NTS, 13 days for NLVF, and 39 days for SNL.

b Based on EPA construction vehicle emission factors (EPA 1985). 
TABLE 2.12 Emission Factors for Site-Clearing Construction Equipment Exhaust

\begin{tabular}{lccccc} 
& \multicolumn{5}{c}{$\begin{array}{c}\text { Emission Factor } \\
\end{array}$} \\
\cline { 2 - 7 } \multicolumn{1}{c}{ Equipment Category } & $\mathrm{PM}_{10}$ & VOCs & $\mathrm{CO}$ & $\mathrm{NO}_{2}$ & $\mathrm{SO}_{2}$ \\
\hline & 2.12 & 1.58 & 14.73 & 34.29 & 3.74 \\
Water tanker & 3.51 & 5.17 & 11.79 & 38.5 & 3.74 \\
Bottom loader/dump grader & 3.03 & 3.31 & 9.4 & 34.16 & 3.73 \\
Bulldozer & 2.66 & 1.53 & 6.55 & 30.41 & 3.73 \\
Grader & & & & & \\
\hline
\end{tabular}

Source: EPA (1985).

\section{Vehicle Exhaust Emission Factors}

The emission factors used to estimate pollutant discharges from the exhausts of site-clearing construction vehicles (Table 2.12) are based on EPA data for heavyduty diesel-powered construction equipment (EPA 1985). The EPA emission factors are a function of construction vehicle type. The vehicle category descriptions in Table 2.12 were provided by LLNL (Foley 1995) but have slightly different category names in the EPA emission factor table. Water tankers, bottom loader/dump graders, bulldozers, and graders are referenced by EPA as off-highway trucks, wheeled loaders, track-type tractors, and motor graders, respectively.

The EPA emission factors are established as a
TABLE 2.13 Estimated Facility Construction Air Pollutant Emissions

\begin{tabular}{lc}
\hline Pollutant & $\begin{array}{c}\text { Emissions } \\
(\mathrm{kg} / \mathrm{yr})\end{array}$ \\
\hline $\mathrm{PM}_{10}$ & 32 \\
$\mathrm{VOCs}$ & 32 \\
$\mathrm{CO}$ & 135 \\
$\mathrm{NO}_{2}$ & 35 \\
$\mathrm{SO}_{2}$ & 35 \\
\hline
\end{tabular}

a Based on construction equipment and vehicle exhaust emissions.

Source: LLNL (1995b). rate of air pollutant emission per unit of fuel consumed (that is, vehicle activity) for a specific manufacturer's model type of vehicle and fuel type. Identification of the vehicle and fuel category types expected to be used in site clearing for NIF was based on the site-clearing activity description provided by LLNL (Foley 1995). 


\subsection{Fugitive $\mathrm{PM}_{10}$ Emissions}

Because of the high degree of soil disturbance, site clearing would cause the greatest volume of $\mathrm{PM}_{10}$ emissions during the construction phase. Thus, annual emissions were estimated for the first year of construction, and site clearing and facility construction were analyzed separately. Emission factors used to develop the $\mathrm{PM}_{10}$ emission rates were estimated from a standard reference source (EPA 1995a, hereinafter referred to as AP-42). In addition, some site-specific values for correction parameters (such as silt content of road surface material) used in the emission factor equation were not available, so appropriate mean values for which the emission factor in AP-42 was developed were used wherever possible. Data on the category types and number of construction vehicles were available (Foley 1995), but equipment specification data (such as vehicle model) needed to specifically apply air pollutant emissions factors were not. Therefore, vehicle specification data in the Caterpillar Performance Handbook (Caterpillar 1992) and data for Ford trucks (Nowinski 1993) were used to assign vehicle emission factors for site-clearing activities. Source activity information for facility construction after site clearing was not available, so a single-value fugitive $\mathrm{PM}_{10}$ emission factor was used to account for the entire construction activity.

In the first subsection below, $\mathrm{PM}_{10}$ emission factors for site clearing are based on specific equipment activity and general facility construction. The second subsection presents a discussion of source activities that are defined to estimate uncontrolled air pollutant emission rates. Finally, dust-control measures and estimates of controlled emission rates are discussed.

\section{Emission Factors}

The derivation of air pollutant emission factors for specific construction equipment activities during site clearing and for general facility construction is described in this section. Input parameters assumed in deriving emission factors are also discussed. The derived uncontrolled $\mathrm{PM}_{10}$ emission factors used to estimate construction emissions are summarized in Table 2.14.

Water Tankers. Two water tanker trucks would be operating to control fugitive dust on unpaved roads and in areas of earth disturbance and earthmoving. The predictive emission factor equation for travel on unpaved roads was taken from Section 13.2.2 of AP-42. This factor is affected by the silt content of unpaved road aggregate, the characteristics of the vehicle (e.g., speed, weight, number of wheels), and the number of dry days per year. For this analysis, a silt content of $12 \%$ (representative of a typical rural dirt road) was used in the emission factor algorithm. A 10-wheel truck with an average weight of $18.1 \mathrm{t}$ (20 tons) was assumed to be operated at a speed of $8 \mathrm{~km} / \mathrm{h}$ ( $5 \mathrm{mph}$ ). It was also assumed that the trucks could be represented by the Ford $7.6 / 9.2-\mathrm{m}^{3}$ (10/12-yd $\left.{ }^{3}\right)$ dump truck (Nowinski 1993), which corresponds to a truck with a water tank capacity of about $22,700 \mathrm{~L}(6,000 \mathrm{gal})$. The number of days with at least $0.3 \mathrm{~cm}(0.01 \mathrm{in}$.) of 
TABLE 2.14 Uncontrolled PM $_{10}$ Emission Factors Used to Develop

Construction Emission Estimates

\begin{tabular}{|c|c|c|c|c|c|}
\hline Construction Phase & $\begin{array}{l}\text { Equipment } \\
\text { Category }\end{array}$ & $\begin{array}{l}\text { Equipment } \\
\text { Model }^{\mathrm{a}}\end{array}$ & $\begin{array}{l}\text { Emission } \\
\text { Factor }\end{array}$ & $\begin{array}{l}\text { Emission } \\
\text { Factor } \\
\text { Unit }\end{array}$ & $\begin{array}{c}\text { AP-42 } \\
\text { Reference }\end{array}$ \\
\hline \multirow[t]{4}{*}{ Site clearing } & Water tanker & $\begin{array}{l}\text { Ford } 7.6 / 9.2 \mathrm{~m}^{3} \\
\text { dump truck }\end{array}$ & $0.50-0.56^{\mathrm{c}}$ & $\mathrm{kg} / \mathrm{VKT}^{\mathrm{d}}$ & Section 13.2 .2 \\
\hline & Grader & CAT $12 \mathrm{G}$ & 0.43 & $\mathrm{~kg} / \mathrm{VKT}$ & Section 11.9 \\
\hline & Bulldozer & CAT D8 & 1.09 & $\mathrm{~kg} / \mathrm{h}$ & Section 11.9 \\
\hline & $\begin{array}{l}\text { Bottom loader/ } \\
\text { dump grader }\end{array}$ & CAT $980 \mathrm{~F}$ & $0.38-0.43^{\mathrm{e}}$ & $\mathrm{kg} / \mathrm{VKT}$ & Section 13.2.2 \\
\hline Facility construction & Various $^{f}$ & Various $^{f}$ & 0.97 & t/ha.mo & Section 13.2.3 \\
\hline \multicolumn{6}{|c|}{$\begin{array}{l}\text { Based on manufacturer's fuel requirement data for assumed equipment models (Foley 1995). CAT is a } \\
\text { product of Caterpillar Company (Caterpillar 1992), and Ford is a product of Ford Motor Company } \\
\text { (Nowinski 1993). }\end{array}$} \\
\hline \multicolumn{6}{|c|}{ b EPA (1995a). } \\
\hline \multicolumn{6}{|c|}{$\begin{array}{l}\text { Due to climatic correction factors (such as number of precipitation days per year), emission factor varies by } \\
\text { site: } 0.50 \text { for LANL and SNL, } 0.52 \text { for LLNL, and } 0.56 \text { for NTS and NLVF. }\end{array}$} \\
\hline \multicolumn{6}{|c|}{$\mathrm{d}$ VKT $=$ vehicle-kilometers traveled. } \\
\hline \multicolumn{6}{|c|}{$\begin{array}{l}\text { Due to climatic correction factor (such as number of precipitation days per year), emission factor varies by } \\
\text { site: } 0.38 \text { for LANL and SNL, } 0.39 \text { for LLNL, and } 0.43 \text { for NTS and NLVF. }\end{array}$} \\
\hline
\end{tabular}

precipitation per year was assumed to be 51 for LLNL, 26 for NTS and NLVF, and 61 for SNL and LANL (Bair 1992). The significance of this factor is that no $\mathrm{PM}_{10}$ emissions would occur on precipitation days.

Graders. Grading would be conducted to level the construction site and to maintain unpaved roads. The predictive emission factor algorithm for grading was taken from Section 11.9 of AP-42. The only variable for this emission factor is the mean grader speed. A value of $11.4 \mathrm{~km} / \mathrm{h}$ $(7.1 \mathrm{mph})$, a geometric mean value for which the emission factor was developed, was assumed for this analysis.

Bulldozers. Bulldozers would be used to excavate soils and to transfer materials to piles accessible to front-end loaders and trucks at the site. The predictive emission factor algorithm for bulldozer operations is contained in Section 11.9 of AP- 42 and is dependent on the silt and moisture content of materials being handled. The average values for overburden silt and moisture content given in Section 11.9 of AP-42 are 6.9\% and 7.9\%, respectively. In addition, for exposed topsoil, 
the average values for silt and moisture content are given as $15 \%$ and $3.4 \%$, respectively, in Section 13.2.4 of AP-42. Because bulldozing disturbs both topsoil and subsurface material, the overall averages of $11 \%$ and $5.7 \%$ for silt and moisture contents of both soil types were used.

Bottom Loaders/Dump Graders. Because no emission factors specific for bottom loaders/dump graders were available, the assumption was made that the emissions from materialmoving activities of those vehicles could, for purposes of this analysis, be represented by use of front-end loaders and that the predictive emission factor equation in Section 13.2.2 of AP-42 for travel on unpaved surfaces would be appropriate for these activities. To estimate emissions, fourwheeled front-end loaders with an average weight of $27.2 \mathrm{t}(30 \mathrm{tons})$ were assumed to be operated on unpaved surfaces at a speed of $8 \mathrm{~km} / \mathrm{h}(5 \mathrm{mph})$, which is the conventional operating speed for this type of vehicle in service. The silt content of the unpaved surfaces on which the vehicles would be working was assumed to be $11 \%$ (the same as for bulldozers).

Facility Construction. The quantity of fugitive dust emissions from construction operations would be proportional to the area being actively worked and to the level of construction activity. One particulate emission factor cited in Section 11.2.3 of AP-42 is $2.7 \mathrm{t}$ of emissions per hectare (1.2 tons/acre) of construction per month of activity (based on a particle size of less than $30 \mu \mathrm{m}$ Stokes' diameter [see the glossary of the PSA]). This value is most applicable to construction operations with (1) medium activity level, (2) moderate silt content, and (3) semiarid climate. The emission factor for $\mathrm{PM}_{10}$ is assumed to be $0.97 \mathrm{t} / \mathrm{ha} \cdot \mathrm{mo}$ ( 0.43 ton/acre $\left.\bullet \mathrm{mo}\right)$ on the basis of the ratio of 0.36 of $\mathrm{PM}_{10}$ to particles of less than $30 \mu \mathrm{m}$ Stokes' diameter. This estimate is based on ratios of 0.36 for unpaved roads in Section 13.2.2 of AP-42 and 0.35 for aggregate handling and storage piles in Section 13.2.4 of AP-42.

\section{Source Activities}

The use of source activity data makes it possible to convert estimated emission factors to uncontrolled emission rates. Source activity for site clearing is based on maximum fuel consumption data (Foley 1995) and fuel consumption rates for heavy equipment models given in the Caterpillar Performance Handbook (Caterpillar 1992) and for Ford trucks given by Nowinski (1993). For this analysis, it was assumed that all the heavy equipment would operate 8 hours each day. Source activities for water tankers, graders, and bottom loaders/dump graders are expressed in terms of vehicle-kilometers traveled (VKT), while source activities for bulldozers are given in terms of hours of operation.

Source activity for facility construction is expressed as the product of the area being worked and months of activity. Total site areas cleared and number of months needed for site clearing and facility construction are listed in Table 2.9. It was conservatively assumed that only one-fourth of 
each site's total construction area would be disturbed in any month during the facility construction period.

\section{Dust-Control Measures}

Measures to control fugitive dust emissions were evaluated to address compliance with air quality standards and regulations and to identify activities to which controls could be applied to minimize potential exposure of the off-site general public to respirable $\left(\mathrm{PM}_{10}\right)$ particulates. The conventional dust-control measure expected to be used at the NIF location during the construction period would be water spraying.

Use of dedicated trucks for spraying water twice daily as a conventional control measure at areas of active excavation and grading was assumed to provide a dust-control efficiency of $50 \%$ (EPA 1989). Control measures for unpaved roads are well documented. In this analysis, a $60 \%$ average control efficiency was assumed on the basis of a traffic volume of 20 vehicles per hour and a water spray application rate of $0.5 \mathrm{~L} / \mathrm{m}^{2}\left(0.11 \mathrm{gal} / \mathrm{yd}^{2}\right)$ every two hours.

Additional control measures could be implemented if a higher control efficiency were needed. Continuous spraying of an active work area with water containing a surfactant provides a conservative control efficiency of 75\% (Muleski 1995). Along with water spraying, petroleum resin or calcium-based dust suppressants could also be applied to on-site roads and roads near the site boundary where heavy traffic is expected. Depending on the application intensity and frequency of water spray with calcium-based suppressants, a control efficiency of more than $90 \%$ could be achieved (Nalco Chemical Company 1987). The use of petroleum resin on unpaved roads provides a control efficiency of more than $90 \%$, but that material is banned in ozone non-attainment and maintenance areas because of its VOC content.

\section{Emission Inventories}

Annual fugitive $\mathrm{PM}_{10}$ emissions were estimated for the first year of construction activities. Included were separate estimates for site clearing and post-site-clearing emissions from facility construction. Estimated annual $\mathrm{PM}_{10}$ fugitive dust emissions associated with construction activities at NIF candidate sites are presented in Table 2.15. 
TABLE 2.15 Estimated Annual $\mathrm{PM}_{10}$ Fugitive Dust Emissions Associated with Construction Activities at National Ignition Facility Candidate Sites

\begin{tabular}{|c|c|c|c|c|c|c|}
\hline \multirow[b]{2}{*}{ Site } & \multirow[b]{2}{*}{$\begin{array}{c}\text { Construction } \\
\text { Phase } \\
\end{array}$} & \multirow[b]{2}{*}{$\begin{array}{l}\text { Equipment } \\
\text { Category }\end{array}$} & \multirow[b]{2}{*}{$\begin{array}{c}\text { Uncontrolled } \\
\text { Emission Factor }\end{array}$} & \multirow[b]{2}{*}{ Activity $^{\mathrm{a}}$} & \multicolumn{2}{|c|}{ Emissions (t/yr) } \\
\hline & & & & & Uncontrolled & Controlled $^{\mathrm{b}}$ \\
\hline \multirow[t]{7}{*}{ LLNL } & Site clearing & Water tanker & $0.52 \mathrm{~kg} / \mathrm{VKT}^{c}$ & $3,862 \mathrm{~km}$ & 2.0 & 0.8 \\
\hline & & Grader & $0.43 \mathrm{~kg} / \mathrm{VKT}$ & $5,488 \mathrm{~km}$ & 2.4 & 1.2 \\
\hline & & Bulldozer & $1.09 \mathrm{~kg} / \mathrm{h}$ & $480 \mathrm{~h}$ & 0.5 & 0.3 \\
\hline & & $\begin{array}{l}\text { Bottom loader/ } \\
\text { dump grader }\end{array}$ & $0.39 \mathrm{~kg} / \mathrm{VKT}$ & $7,725 \mathrm{~km}$ & 3.1 & 1.5 \\
\hline & & Subtotal & & & 8.0 & 3.8 \\
\hline & $\begin{array}{l}\text { Facility } \\
\text { construction }\end{array}$ & $ـ^{d}$ & 0.97 tha.mo & $20.6 \mathrm{ha} / \mathrm{mo}$ & 19.9 & 10.0 \\
\hline & Total & & & & 27.9 & 13.8 \\
\hline \multirow[t]{7}{*}{ LANL } & Site clearing & Water tanker & $0.50 \mathrm{~kg} / \mathrm{VKT}$ & $2,060 \mathrm{~km}$ & 1.0 & 0.4 \\
\hline & & Grader & $0.43 \mathrm{~kg} / \mathrm{VKT}$ & $2,929 \mathrm{~km}$ & 1.3 & 0.6 \\
\hline & & Bulldozer & $1.09 \mathrm{~kg} / \mathrm{h}$ & $256 \mathrm{~h}$ & 0.3 & 0.1 \\
\hline & & $\begin{array}{l}\text { Bottom loader/ } \\
\text { dump grader }\end{array}$ & $0.38 \mathrm{~kg} / \mathrm{VKT}$ & $4,120 \mathrm{~km}$ & 1.6 & 0.8 \\
\hline & & Subtotal & & & 4.2 & 1.9 \\
\hline & $\begin{array}{l}\text { Facility } \\
\text { construction }\end{array}$ & - & 0.97 tha $\mathrm{mo}$ & $11.6 \mathrm{ha} / \mathrm{mo}$ & 11.2 & 5.6 \\
\hline & Total & & & & 15.4 & 7.5 \\
\hline \multirow[t]{7}{*}{ NTS } & Site clearing & Water tanker & $0.56 \mathrm{~kg} / \mathrm{VKT}$ & $9,399 \mathrm{~km}$ & 5.3 & 2.1 \\
\hline & & Grader & $0.43 \mathrm{~kg} / \mathrm{VKT}$ & $13,341 \mathrm{~km}$ & 5.8 & 2.9 \\
\hline & & Bulldozer & $1.09 \mathrm{~kg} / \mathrm{h}$ & $1,168 \mathrm{~h}$ & 1.3 & 0.6 \\
\hline & & $\begin{array}{l}\text { Bottom loader/ } \\
\text { dump grader }\end{array}$ & $0.43 \mathrm{~kg} / \mathrm{VKT}$ & $18,797 \mathrm{~km}$ & 8.0 & 4.0 \\
\hline & & Subtotal & & & 20.4 & 9.6 \\
\hline & $\begin{array}{l}\text { Facility } \\
\text { construction }\end{array}$ & $-\mathrm{d}$ & $0.97 \mathrm{t} / \mathrm{ha} \cdot \mathrm{mo}$ & $43.5 \mathrm{ha} / \mathrm{mo}$ & 42.2 & 21.1 \\
\hline & Total & & & & 62.6 & 30.7 \\
\hline \multirow[t]{7}{*}{ NLVF } & Site clearing & Water tanker & $0.56 \mathrm{~kg} / \mathrm{VKT}$ & $1,674 \mathrm{~km}$ & 0.9 & 0.4 \\
\hline & & Grader & $0.43 \mathrm{~kg} / \mathrm{VKT}$ & $2,382 \mathrm{~km}$ & 1.0 & 0.5 \\
\hline & & Bulldozer & $1.09 \mathrm{~kg} / \mathrm{h}$ & $208 \mathrm{~h}$ & 0.2 & 0.1 \\
\hline & & $\begin{array}{l}\text { Bottom loader/ } \\
\text { dump grader }\end{array}$ & $0.43 \mathrm{~kg} / \mathrm{VKT}$ & $3,347 \mathrm{~km}$ & 1.4 & 0.7 \\
\hline & & Subtotal & & & 3.5 & 1.7 \\
\hline & $\begin{array}{l}\text { Facility } \\
\text { construction }\end{array}$ & $-d$ & 0.97 tha.mo & $9.5 \mathrm{ha} / \mathrm{mo}$ & 9.2 & 4.6 \\
\hline & Total & & & & 12.7 & 6.3 \\
\hline
\end{tabular}


TABLE 2.15 (Cont.)

\begin{tabular}{|c|c|c|c|c|c|c|}
\hline \multirow[b]{2}{*}{ Site } & \multirow[b]{2}{*}{$\begin{array}{l}\text { Construction } \\
\text { Phase }\end{array}$} & \multirow[b]{2}{*}{$\begin{array}{l}\text { Equipment } \\
\text { Category }\end{array}$} & \multirow[b]{2}{*}{$\begin{array}{l}\text { Uncontrolled } \\
\text { Emission Factor }\end{array}$} & \multirow[b]{2}{*}{ Activity $^{\mathrm{a}}$} & \multicolumn{2}{|c|}{ Emissions (t/yr) } \\
\hline & & & & & Uncontrolled & Controlled $^{\mathrm{b}}$ \\
\hline \multirow[t]{7}{*}{ SNL } & Site clearing & Water tanker & $0.50 \mathrm{~kg} / \mathrm{VKT}$ & $5,021 \mathrm{~km}$ & 2.5 & 1.0 \\
\hline & & Grader & $0.43 \mathrm{~kg} / \mathrm{VKT}$ & $7,129 \mathrm{~km}$ & 3.1 & 1.5 \\
\hline & & Bulldozer & $1.09 \mathrm{~kg} / \mathrm{h}$ & $624 \mathrm{~h}$ & 0.7 & 0.3 \\
\hline & & $\begin{array}{l}\text { Bottom loader/ } \\
\text { dump grader }\end{array}$ & $0.38 \mathrm{~kg} / \mathrm{VKT}$ & $10,042 \mathrm{~km}$ & 3.8 & 1.9 \\
\hline & & Subtotal & & & 10.1 & 4.7 \\
\hline & $\begin{array}{l}\text { Facility } \\
\text { construction }\end{array}$ & $-d$ & $0.97 \mathrm{t} / \mathrm{ha} \cdot \mathrm{mo}$ & $26.0 \mathrm{ha} / \mathrm{mo}$ & 25.2 & 12.6 \\
\hline & Total & & & & 35.3 & 17.3 \\
\hline
\end{tabular}

a Construction activities are assumed to occur 8 hours per day. The values for distance $(\mathrm{km})$ traveled by equipment or hours of operation are for the total site clearing activity. It is also assumed that one-fourth of the site clearing area would be disturbed or remain disturbed in any month during the facility construction period.

b Conventional dust-control measures are assumed, such as $50 \%$ control for excavation area and $60 \%$ for traffic on unpaved road (see text).

c VKT $=$ vehicle-kilometers traveled.

d A number of different types of construction equipment would be involved in this phase.

\subsection{Air Quality Modeling Analysis for Site-Clearing Activities}

\section{Air Quality Model and Input Parameters}

As shown in Table 2.15 and discussed in Section 2.1.2.1.2, $\mathrm{PM}_{10}$ emission rates for site clearing at LLNL were estimated to be $3.8 \mathrm{t} /$ month $(4.2 \mathrm{tons} / \mathrm{month})$ and $1.7 \mathrm{t} / \mathrm{month}$ (1.9 tons/month) with conventional and additional dust control measures, respectively. The controlled emission rate for facility construction was estimated to be 0.9 t/month $(1.0 \mathrm{ton} / \mathrm{month})$. Emission rates during the relatively short site-clearing period, which would involve significant soil disturbance, would be much higher. Over the short term, unfavorable meteorological conditions (low wind speed, persistent wind direction, and/or stable atmosphere) could cause high $\mathrm{PM}_{10}$ concentrations at areas accessible to the general public. However, over the long term, winds shift in all directions, thus minimizing $\mathrm{PM}_{10}$ concentrations at any fixed receptor locations. Therefore, only short-term (24-hour) air quality impacts resulting from site clearing were analyzed.

Selection of an appropriate model to assess 24-hour air quality impacts from fugitive dust $\mathrm{PM}_{10}$ sources was based on U.S. Environmental Protection Agency (EPA) guidance (EPA 1993). For this analysis, the most appropriate EPA model meeting EPA criteria was determined to be the Industrial Source Complex Short Term Model (ISCST2) (EPA 1992a,b), a steady-state Gaussian plume dispersion model. The ISCST2 model is limited in its effectiveness for considering the effects 
of uneven terrain; its application is restricted to areas of simple or flat terrain. In general, emissions from area sources are assumed to be of neutral buoyancy. Different from stack emission sources, plume phenomena such as downwash and impact on elevated terrain features are not considered relevant for modeling area sources. Moreover, ground-level, neutral-buoyant area sources follow terrain features along with the wind. For this modeling analysis, the following assumptions were made:

- All candidate sites are classified as being in a predominantly "rural" setting, except for the NLVF site, which is classified as "urban."

- Construction activities would occur during one daytime 8-hour shift each day.

- General areas between the construction site and receptor locations of interest are in flat terrain.

- Dust emissions would be released from the site-clearing area at a constant spatial and temporal emission rate.

- All $\mathrm{PM}_{10}$ particles are assumed to stay airborne in the modeling domain; that is, gravitational settling and removal by dry deposition are assumed negligible and not evaluated.

- Receptor locations are placed at the site boundaries or roads accessible to the general public.

\section{Meteorological Data Summary}

Meteorological conditions most representative of each candidate site were selected to model $\mathrm{PM}_{10}$ fugitive dust emissions from site clearing. For LLNL, 1994 on-site surface meteorological data were used, and a constant mixing height of $600 \mathrm{~m}(1,970 \mathrm{ft})$ was assumed throughout the year (LLNL 1995a). For LANL, 1994 on-site surface meteorological data were used, and seasonal average morning mixing height data for Albuquerque, New Mexico (Holzworth 1972), were assumed throughout the corresponding months (LANL 1995). For NTS, surface meteorological data and mixing height data from the nearby Desert Rock National Weather Service station for 1987-1991 were used (EPA 1995b). For NLVF, surface meteorological data from Las Vegas/McCarran International Airport and mixing height data from Desert Rock, Nevada, for 1987-1991 were used (EPA 1995b). For SNL, surface meteorological data and mixing height data from nearby Albuquerque International Airport for 1987-1991 were used (EPA 1995b). 


\section{Results and Discussion}

Air quality modeling analysis was conducted to determine potential impacts on ambient air quality from site clearing. In the following subsections, the results are compared with ambient air quality standards for the five NIF candidate sites. More detailed site-specific air quality information is presented in Section 2.11 of this document and Chapter I.4 of the NIF PSA (Appendix I of DOE 1996).

Lawrence Livermore National Laboratory. The national and state 24-hour $\mathrm{PM}_{10}$ standards are 150 and $50 \mu \mathrm{g} / \mathrm{m}^{3}$, respectively. The maximum 24-hour average $\mathrm{PM}_{10}$ background concentration of $84 \mu \mathrm{g} / \mathrm{m}^{3}$ in the LLNL area is already above the state ambient air quality standard (SAAQS) of $50 \mu \mathrm{g} / \mathrm{m}^{3}$. Accordingly, site clearing should be conducted so as to minimize further impacts on ambient air quality. With conventional dust control (water spray twice per day that results in a $50 \%$ control for excavation and water spray every two hours that results in a $60 \%$ control for traffic on unpaved roads), a maximum 24-hour average $\mathrm{PM}_{10}$ concentration of $104 \mu \mathrm{g} / \mathrm{m}^{3}$ over background is predicted at the site boundary (about $350 \mathrm{~m}[1,150 \mathrm{ft}]$ east of the proposed NIF location).

Operation with additional dust control measures that involve continuous water spraying and/or use of a chemical dust suppressant would reduce $\mathrm{PM}_{10}$ dust emissions from site clearing $75 \%$ and $\mathrm{PM}_{10}$ emissions from traffic on unpaved roads by $90 \%$. These measures would bring maximum 24-hour $\mathrm{PM}_{10}$ concentrations down to $46 \mu \mathrm{g} / \mathrm{m}^{3}$ over the background concentration. Including background concentration, maximum 24-hour concentrations would still be higher than the SAAQS for $\mathrm{PM}_{10}$. Ambient air quality impacts associated with site clearing would be limited to the area just outside the site boundary, which the general public is expected to occupy infrequently. Site clearing at LLNL would be expected to last for only a month, so ambient air quality impacts associated with those activities would be local and temporary.

Determination of air quality impacts of construction fugitive dust $\left(\mathrm{PM}_{10}\right)$ emissions would normally not be required by $\mathrm{BAAQMD}$ as part of permitting process. Modeling estimates that predict violations of the SAAQS for $\mathrm{PM}_{10}$ would, under review by the $B A A Q M D$, probably require that only dust control mitigation procedures be implemented during construction (DeBoisblance 1995).

Los Alamos National Laboratory. The maximum 24-hour average $\mathrm{PM}_{10}$ background concentration representative of the LANL site is $30 \mu \mathrm{g} / \mathrm{m}^{3}$. With conventional dust control (water spray twice a day that results in $50 \%$ control for excavation and water spray every two hours that results in a $60 \%$ control for traffic on unpaved roads), maximum 24-hour average $\mathrm{PM}_{10}$ concentrations of $94 \mu \mathrm{g} / \mathrm{m}^{3}$ over background are predicted at the public access road (West Jemez Road, which runs north of the NIF location at the closest site boundary distance of $460 \mathrm{~m}$ [1,500 ft] 
from the proposed NIF location). The maximum $\mathrm{PM}_{10}$ concentration of $124 \mu \mathrm{g} / \mathrm{m}^{3}$, including background concentration, would be below the 24-hour national standard of $150 \mu \mathrm{g} / \mathrm{m}^{3}$ for $\mathrm{PM}_{10}$. Site clearing at LANL would be expected to last for half a month, so ambient air quality impacts associated with site clearing would be minor, local, and temporary.

Nevada Test Site. The maximum 24-hour average $\mathrm{PM}_{10}$ background concentration representative of the NTS site is $173 \mu \mathrm{g} / \mathrm{m}^{3}$, which exceeds the national and state standard of $150 \mu \mathrm{g} / \mathrm{m}^{3}$. This situation is caused by arid soil conditions typical of the region. Therefore, site clearing should be carried out so as to minimize additional impacts on ambient air quality. With conventional dust control (water spray twice a day that results in 50\% control for excavation and water spray every two hours that results in a $60 \%$ control for traffic on unpaved roads), maximum 24-hour average $\mathrm{PM}_{10}$ concentrations of $2 \mu \mathrm{g} / \mathrm{m}^{3}$ over background are predicted at the site boundary. This value is very small because the site boundary would be a considerable distance from the siteclearing activity at the NIF location (approximately $4.5 \mathrm{~km}$ [2.8 mi] east of the proposed NIF location). The predicted maximum $\mathrm{PM}_{10}$ concentration increase of $2 \mu \mathrm{g} / \mathrm{m}^{3}$ at the site boundary is only $1.1 \%$ and $1.3 \%$ of the background concentration and the national standard, respectively. Site clearing at NTS would be expected to last for two and a half months, so ambient air quality impacts associated with site clearing would be local and temporary.

North Las Vegas Facility. The maximum 24-hour average $\mathrm{PM}_{10}$ background concentration representative of the NLVF site is $114 \mu \mathrm{g} / \mathrm{m}^{3}$, while both the national and state standards are $150 \mu \mathrm{g} / \mathrm{m}^{3}$. This high ambient concentration is a result of arid soil conditions typical of the region. Accordingly, site clearing should be carried out so as to minimize the impact on ambient air quality. With conventional dust control, a predicted maximum 24-hour average $\mathrm{PM}_{10}$ concentration of $270 \mu \mathrm{g} / \mathrm{m}^{3}\left(156 \mu \mathrm{g} / \mathrm{m}^{3}\right.$ over the maximum background level of $\left.114 \mu \mathrm{g} / \mathrm{m}^{3}\right)$ would result at the site boundary ( $10 \mathrm{~m}[32 \mathrm{ft}]$ north of the proposed NIF location). This concentration would be above the national and state standards for $\mathrm{PM}_{10}$.

Operation with additional dust control measures that involve continuous water spray and/or use of chemical dust suppressant would reduce dust emissions from site clearing by $75 \%$ and from traffic on unpaved roads by $90 \%$. These measures would bring the maximum 24-hour average concentrations down to $183 \mu \mathrm{g} / \mathrm{m}^{3}$ ( $69 \mu \mathrm{g} / \mathrm{m}^{3}$ over the background concentration). This concentration would still be higher than the national and state standard for $\mathrm{PM}_{10}$. Thus, other approaches (such as reduction of activity or use of intensified dust control measures) would be needed to comply with the national and state standard for $\mathrm{PM}_{10}$. For example, by reducing the workload by half (which would increase the site-clearing period to one month), the maximum $\mathrm{PM}_{10}$ concentration, including background concentration, would be $149 \mu \mathrm{g} / \mathrm{m}^{3}$. This concentration would comply with the national and state 24-hour standard for $\mathrm{PM}_{10}$. In either case, site clearing at NLVF would be expected to last 
for a month or less, so ambient air quality impacts associated with site clearing would be local and temporary.

Sandia National Laboratories. The maximum 24-hour average $\mathrm{PM}_{10}$ background concentration representative of the SNL site is $40 \mu \mathrm{g} / \mathrm{m}^{3}$. With conventional dust control, a maximum 24-hour average $\mathrm{PM}_{10}$ concentration of $52 \mu \mathrm{g} / \mathrm{m}^{3}\left(12 \mu \mathrm{g} / \mathrm{m}^{3}\right.$ over background) is predicted at the closest site boundary $(1.0 \mathrm{~km}$ [0.6 mi] north-northeast of the NIF location). This concentration would be considerably below the national standard of $150 \mu \mathrm{g} / \mathrm{m}^{3}$ for $\mathrm{PM}_{10}$. Site clearing at SNL would be expected to last over a month, so ambient air quality impacts associated with site clearing would be negligible, local, and temporary.

\subsubsection{Operating Air Pollutant Emissions}

\subsection{Emission Sources and Levels}

Air pollutant emissions from NIF operation would consist primarily of exhaust released during fossil fuel combustion and volatile organic compounds (VOCs) that, more significantly, would be emitted as vapors during use of solvents as cleaning agents. Ethanol would be the primary VOC solvent expected to be used (LLNL 1995b). Fossil fuel would be burned in external combustion equipment producing space heat and hot water for the buildings included in the NIF complex and in performing maintenance runs of stationary internal combustion engines used to power stand-by electric generators.

External combustion units, commonly referred to as boilers, are used to produce space heat and hot water. All candidate sites except the NTS would use natural gas as the fuel of choice to meet the space heat and hot water demands for the NIF complex (LLNL 1995b). NTS has reported that liquefied petroleum gas (LPG) would be used there (White 1995b). Stationary internal combustion engines used as prime-movers for stand-by electric generators would burn diesel fuel (LLNL 1995b).

The annual operating air pollutant emissions for each of the NIF candidate sites are summarized in Table 2.16 (see also DOE 1996, Appendix I, Sections I.4.1.2.2.1, I.4.2.2.2.1, I.4.3.2.2.1, I.4.4.2.2.1, and I.4.5.2.2.1). Air pollutant combustion emissions were estimated by application of EPA air pollutant emission factors to the design energy demand (LLNL 1995b) tailored to each specific site's proposal for new building construction for the NIF project. Aside from a small amount of fossil fuel combustion, VOC emission estimates are based on evaporative emissions (primarily ethanol - see Section 4, Tables 4.6 and 4.7) from estimated solvent use for component cleaning at the Laser and Target Area Building and the Optics Assembly Area. Estimated 
TABLE 2.16 Total National Ignition Facility Estimated Operating Emissions at Candidate Sites ${ }^{a}$

\begin{tabular}{|c|c|c|c|c|c|}
\hline \multirow[b]{2}{*}{ Pollutant } & \multicolumn{2}{|c|}{$\begin{array}{c}\text { Laser and Target Area } \\
\text { Building Emissions (t/yr) }\end{array}$} & \multicolumn{2}{|c|}{$\begin{array}{l}\text { Support Facility } \\
\text { Emissions (t/yr) }\end{array}$} & \multirow{2}{*}{$\begin{array}{c}\text { Total } \\
\text { Emissions } \\
(\mathrm{t} / \mathrm{yr})\end{array}$} \\
\hline & Combustion $^{\mathrm{b}}$ & Other ${ }^{c}$ & Combustion $^{\mathrm{b}}$ & Other $^{c}$ & \\
\hline \multicolumn{6}{|l|}{ LLNL } \\
\hline $\mathrm{PM}_{10}$ & 0.128 & $-^{d}$ & 0.035 & - & 0.163 \\
\hline VOCs & 0.027 & 0.125 & 0.038 & 0.375 & 0.565 \\
\hline $\mathrm{CO}$ & 0.327 & - & 0.111 & - & 0.438 \\
\hline $\mathrm{NO}_{2}$ & 1.309 & 一 & 0.481 & - & 1.790 \\
\hline $\mathrm{SO}_{2}$ & 0.007 & 一 & 0.027 & 一 & 0.034 \\
\hline Lead $^{\text {e }}$ & - & - & - & - & 一 \\
\hline \multicolumn{6}{|l|}{ LANL } \\
\hline $\mathrm{PM}_{10}$ & 0.128 & - & 0.047 & - & 0.175 \\
\hline VOCs & 0.027 & 0.125 & 0.041 & 0.375 & 0.568 \\
\hline $\mathrm{CO}$ & 0.327 & - & 0.147 & - & 0.474 \\
\hline $\mathrm{NO}_{2}$ & 1.309 & - & 0.604 & - & 1.913 \\
\hline $\mathrm{SO}_{2}$ & 0.007 & - & 0.028 & - & 0.035 \\
\hline Lead $^{\mathrm{e}}$ & - & - & - & - & - \\
\hline \multicolumn{6}{|l|}{ NTS } \\
\hline $\mathrm{PM}_{10}$ & 0.065 & - & 0.011 & - & 0.076 \\
\hline VOCs & 0.050 & 0.125 & 0.009 & 0.375 & 0.559 \\
\hline $\mathrm{CO}$ & 0.318 & - & 0.056 & - & 0.374 \\
\hline $\mathrm{NO}_{2}$ & 1.883 & 一 & 0.331 & - & 2.214 \\
\hline $\mathrm{SO}_{2}$ & 0.004 & - & $<0.001$ & - & 0.004 \\
\hline Lead $^{\mathrm{e}}$ & - & - & - & - & - \\
\hline \multicolumn{6}{|l|}{ NLVF } \\
\hline $\mathrm{PM}_{10}$ & 0.128 & - & 0.083 & - & 0.211 \\
\hline VOCs & 0.027 & 0.125 & 0.047 & 0.375 & 0.574 \\
\hline $\mathrm{CO}$ & 0.327 & - & 0.234 & - & 0.561 \\
\hline $\mathrm{NO}_{2}$ & 1.309 & - & 0.973 & - & 2.282 \\
\hline $\mathrm{SO}_{2}$ & 0.007 & - & 0.030 & - & 0.037 \\
\hline Lead $^{e}$ & - & - & - & - & - \\
\hline
\end{tabular}


TABLE 2.16 (Cont.)

\begin{tabular}{|c|c|c|c|c|c|}
\hline \multirow[b]{2}{*}{ Pollutant } & \multicolumn{2}{|c|}{$\begin{array}{l}\text { Laser and Target Area } \\
\text { Building Emissions ( } \mathrm{t} / \mathrm{yr})\end{array}$} & \multicolumn{2}{|c|}{$\begin{array}{l}\text { Support Facility } \\
\text { Emissions (t/yr) }\end{array}$} & \multirow{2}{*}{$\begin{array}{c}\text { Total } \\
\text { Emission } \\
(\mathrm{t} / \mathrm{yr})\end{array}$} \\
\hline & Combustion $^{b}$ & Other $^{c}$ & Combustion $^{\mathrm{b}}$ & Other $^{c}$ & \\
\hline \multicolumn{6}{|l|}{ SNL } \\
\hline $\mathrm{PM}_{10}$ & 0.128 & 一 & 0.070 & 一 & 0.198 \\
\hline VOCs & 0.027 & 0.125 & 0.045 & 0.375 & 0.572 \\
\hline $\mathrm{CO}$ & 0.327 & - & 0.201 & 一 & 0.528 \\
\hline $\mathrm{NO}_{2}$ & 1.309 & 一 & 0.839 & 一 & 2.148 \\
\hline $\mathrm{SO}_{2}$ & 0.007 & 一 & 0.029 & - & 0.036 \\
\hline Lead $^{e}$ & - & - & - & - & 一 \\
\hline
\end{tabular}

a Air pollutant emission estimates (metric tons [t] [1,000 kg] per year) based on design annual energy use requirements (LLNL 1995b), adjusted to reflect new support building construction energy demand only, using fuel-specific air pollutant emission factors (EPA 1995a).

b Emission factors selected to represent emissions from gas-fired external combustion units rated at from 10,560 to $105,600 \mathrm{MJ} / \mathrm{h}$, assuming no pollutant controls and stationary internal combustion engines burning diesel fuel.

c VOC (primarily ethanol) emissions from solvent cleaning (LLNL 1995b).

d $-=$ Not applicable.

e No emission factor cited; assumed negligible.

VOC emissions are $500 \mathrm{~kg} / \mathrm{yr}(1,102 \mathrm{lb} / \mathrm{yr})(125 \mathrm{~kg} / \mathrm{yr}$ [276 lb/yr] at the Laser and Target Area Building and $375 \mathrm{~kg} / \mathrm{yr}$ [827 lb/yr] at the Optics Assembly Area) (LLNL 1995b).

Table 2.16 summarizes air pollutant emissions from (1) combustion of fossil fuel for space heat and hot water energy demand and for operation of prime mover stand-by generators, and (2) release of VOCs from use of solvents. Air pollutant emissions are summarized separately for the Laser and Target Area Building, which would have to be constructed at all of the candidate sites, and for all other new buildings required to support NIF operations. Construction of the additional buildings to support NIF would vary among sites, since some existing buildings would be used to support NIF at all sites (see Section 2.1.2.2.3).

The annual operating air pollutant emissions listed in Table 2.16 for NIF are significantly below the annual emission levels that would require a determination that a federal action conforms 
to a state implementation plan to attain and maintain air quality (40 CFR 6, 51, and 93). For federal actions, a conformity determination is required for each pollutant where the total of direct and indirect emissions in a non-attainment or maintenance area caused by a federal action would equal or exceed certain limits ( 40 CFR 51.853 or 93.153 ). The annual air pollutant emission limits that would initiate the need for ("trigger") a conformity analysis are listed in Tables 2.17 and 2.18 (see Appendix I, Section I.5.2, DOE 1996, for discussion).

The air pollutant emission triggering levels listed in Tables 2.17 and 2.18 indicate that the lowest annual emission level that triggers a conformity analysis is a federal action that causes an emission of $9 \mathrm{t} / \mathrm{yr}$ (10 tons/yr) of VOCs or $\mathrm{NO}_{2}$ in an extreme non-attainment area (Table 2.17). All the other annual air pollutant triggering emission levels range from 23 to $91 \mathrm{t} / \mathrm{yr}$ ( 25 to $100 \mathrm{tons} / \mathrm{yr}$ ). Comparison of summary operating emissions data in Table 2.16 with emission triggering levels in Tables 2.17 and 2.18 indicates that estimated $\mathrm{NO}_{2}$ and VOC emissions for all sites are well below the 9-t/yr (10-ton/yr) triggering level, and none of the proposed NIF sites is in an extreme nonattainment area for $\mathrm{O}_{3}$ (see Section 2.1 of this document and Sections I.4.1.1.2.2, I.4.2.1.2.2, I.4.3.1.2.2, I.4.4.1.2.2, and I.4.5.1.2.2 of Appendix I, DOE 1996). Among all sites, the maximum estimated NIF annual operating emission of any air pollutant is less than $3 \mathrm{t} / \mathrm{yr}$ ( 3.3 tons/yr), compared with the lowest air emission triggering level of $23 \mathrm{t} / \mathrm{y}$ (25 tons/yr) that could apply to any of the sites. Ambient air quality impacts of operating emissions were not analyzed by dispersion modeling because these estimated operating emissions are so low. Also, climate variations among sites that would affect space heat energy demand were not evaluated because operating emissions from heating equipment would be so low.

\subsection{Operating Air Pollutant Emission Factors}

No external or internal combustion source is $100 \%$ efficient. The incomplete combustion of fossil fuels to water vapor and carbon dioxide $\left(\mathrm{CO}_{2}\right)$ results in the emission of air pollutants. The EPA has developed an air pollutant emission factor manual that provides estimates of air pollutant emissions from a number of sources, including external and internal combustion units. That manual, commonly referred to as AP-42 (EPA 1995a), is often used by state and local regulatory agencies in the permitting process to determine source compliance with air pollutant regulations in lieu of requiring a stack test.

Annual air pollutant operating emissions from fossil fuel combustion depend on fuel types and quantities of fuel burned during the year. For this NIF analysis, the annual quantity of fuel expected to be burned to produce space heat and hot water was determined from the design energy demand or quantity of fuel required, as indicated in Table 2.19 for the NIF Laser and Target Area Building and Table 2.20 for site-specific new support building construction. The annual quantity of 
TABLE 2.17 Non-Attainment Area Federal Facility Emission Limits Requiring Conformity Determination

\begin{tabular}{|c|c|}
\hline Pollutant/Attainment Status & $\begin{array}{c}\text { Emission Limit } \\
\text { (tons/yr) }^{\mathrm{a}}\end{array}$ \\
\hline Ozone (VOC and $\mathrm{NO}_{2}$ ) serious non-attainment & 50 \\
\hline Ozone (VOC and $\mathrm{NO}_{2}$ ) severe non-attainment & 25 \\
\hline Ozone (VOC and $\mathrm{NO}_{2}$ ) extreme non-attainment & 10 \\
\hline Other ozone non-attainment outside an ozone transport region & 100 \\
\hline $\begin{array}{l}\text { Marginal and moderate non-attainment inside an ozone } \\
\text { transport region for VOCs }\end{array}$ & 50 \\
\hline $\begin{array}{l}\text { Marginal and moderate non-attainment inside an ozone } \\
\text { transport region for nitrogen oxides }\left(\mathrm{NO}_{\mathrm{x}}\right)\end{array}$ & 100 \\
\hline $\begin{array}{l}\text { Marginal and moderate non-attainment inside an ozone } \\
\text { transport region for VOCs }\end{array}$ & 50 \\
\hline CO for all non-attainment areas & 100 \\
\hline $\mathrm{SO}_{2}$ or $\mathrm{NO}_{2}$ for all non-attainment areas & 100 \\
\hline $\mathrm{PM}_{10}$ for moderate non-attainment areas & 100 \\
\hline $\mathrm{PM}_{10}$ for serious non-attainment areas & 70 \\
\hline Lead for all non-attainment areas & 25 \\
\hline
\end{tabular}

${ }^{\mathrm{a}}$ To determine metric tons per year ( $\mathrm{t} / \mathrm{yr}$ ), multiply by 0.90718 .

Source: 40 CFR 6, 51, and 93.

TABLE 2.18 Maintenance Area Federal Facility Emission Limits Requiring Conformity Determination

\section{Pollutant/Attainment Status}

Ozone $\left(\mathrm{NO}_{\mathrm{x}}, \mathrm{SO}_{2}\right.$, or $\left.\mathrm{NO}_{2}\right)$ for all maintenance areas

Ozone (VOCs) for maintenance areas inside an ozone transport region

Ozone (VOCs) for maintenance areas outside an ozone transport region

Carbon monoxide for all maintenance areas

$\mathrm{PM}_{10}$ for maintenance areas

Lead for all maintenance areas

a To determine metric tons per year (t/yr), multiply by 0.90718 .

Source: 40 CFR 6, 51, and 93.
Emission Limit (tons/yr) $^{\mathrm{a}}$

100

100 
TABLE 2.19 Estimated Design Annual Energy Requirements for the National Ignition Facility

\begin{tabular}{llll}
\hline \multicolumn{1}{c}{ Facility } & \multicolumn{1}{c}{ Use } & \multicolumn{1}{c}{ Fuel Type } & \multicolumn{1}{c}{$\begin{array}{c}\text { Annual Fuel } \\
\text { Consumption }\end{array}$} \\
\hline $\begin{array}{l}\text { NIF Laser and Target } \\
\text { Area Building }\end{array}$ & $\begin{array}{l}\text { Space heat } \\
\text { Domestic hot water } \\
\text { Prime mover for stand-by } \\
\text { electric generator }\end{array}$ & $\begin{array}{l}\text { Natural gas or LPG } \\
\text { Natural gas or LPG }\end{array}$ & $\begin{array}{l}21.075 \times 10^{6} \mathrm{MJ} \\
\text { Dif support facilities }\end{array}$ \\
& $\begin{array}{l}\text { Space heat and hot water } \\
\text { Prime mover for stand-by } \\
\text { electric generator }\end{array}$ & Natural gas or LPG & $320 \mathrm{~L}$ \\
& & Diesel & $19.5 \times 10^{6} \mathrm{MJ}$ \\
& & $5,500 \mathrm{~L}$ \\
\hline
\end{tabular}

a Design energy demand estimate for full complement of NIF support building complex.

Sources: LLNL (1995b); White (1995b).

TABLE 2.20 Site-Specific Energy Demand for New Support Buildings

\begin{tabular}{lccc}
\hline Site & $\begin{array}{c}\text { Total Area of New } \\
\text { Support Building } \\
\text { Construction }\left(\mathrm{m}^{2}\right)\end{array}$ & $\begin{array}{c}\text { Energy Demand } \\
\text { Scale Factor }^{\mathrm{a}} \\
\text { (dimensionless) }^{2}\end{array}$ & $\begin{array}{c}\text { New } \\
\text { Support Building } \\
\text { Energy Demand } \\
\left(10^{6} \mathrm{MJ} / \mathrm{yr}\right)\end{array}$ \\
\hline LLNL & 1,858 & 0.07 & 1.37 \\
LANL & 4,645 & 0.174 & 3.39 \\
NTS & 5,341 & 0.201 & 3.91 \\
NLVF & 13,133 & 0.491 & 9.57 \\
SNL & 9,988 & 0.376 & 7.33 \\
\hline
\end{tabular}

a The energy demand scale factor is the ratio of new construction building area size $\left(\mathrm{m}^{2}\right)$ to the sum of support building complex design area sizes $\left(26,722 \mathrm{~m}^{2}\right)$ applied to the total support building complex design energy demand of $19,500,000 \mathrm{MJ} / \mathrm{yr}$. 
diesel fuel consumed by stand-by generators for both the NIF Laser and Target Area Building and support buildings is listed in Table 2.19. Quantities of annual air pollutant emissions were estimated by multiplying the air pollutant emission factors (EPA 1995a) by the amount of fuel expected to be burned. The EPA fossil fuel air pollutant emission factors are keyed to the amount of fuel used either in terms of fuel unit energy content or volume. The EPA emission factors used to compute fossil fuel combustion emissions in this analysis are identified in Table 2.21 .

Table 2.21 lists air pollutant emission factors for external combustion units (boilers) burning natural gas. These emission factors are a function of boiler size, which is determined by the boiler rated heat input. The emission factors cited in Table 2.21 cover a very broad range of boiler sizes, from $10,560 \mathrm{MJ} / \mathrm{h}$ to $105,600 \mathrm{MJ} / \mathrm{h}\left(1 \times 10^{7}\right.$ to $\left.1 \times 10^{8} \mathrm{Btu} / \mathrm{h}\right)$. On the basis of the anticipated NIF space heat and hot water energy demand, this range should be sufficient to encompass the size

TABLE 2.21 Air Pollutant Emission Factors for External Combustion Units Burning Natural Gas or LPG and for Stationary Internal Combustion Engines

\begin{tabular}{|c|c|c|c|c|c|}
\hline \multirow[b]{2}{*}{ Pollutant } & \multicolumn{2}{|c|}{$\begin{array}{c}\text { Natural-Gas-Fired } \\
\text { Boiler }^{\mathbf{a}}\end{array}$} & \multicolumn{2}{|c|}{$\begin{array}{l}\text { LPG (propane)- } \\
\text { Fired Boiler }\end{array}$} & \multirow{2}{*}{$\begin{array}{c}\text { Uncontrolled } \\
\text { Stationary Diesel } \\
\text { Internal Combustion } \\
\text { Engines } \\
\text { Emission } \\
\text { Factor } \\
\text { (g/MJ) }\end{array}$} \\
\hline & $\begin{array}{c}\text { Emission } \\
\text { Factor } \\
\left(\mathrm{kg} / 10^{6} \mathrm{~m}^{3}\right)\end{array}$ & $\begin{array}{l}\text { Emission } \\
\text { Factor }^{\mathrm{c}} \\
\text { (mg/MJ) }\end{array}$ & $\begin{array}{c}\text { Emission } \\
\text { Factor } \\
\left(\mathrm{g} / 10^{3} \mathrm{~L}\right)\end{array}$ & $\begin{array}{c}\text { Emission } \\
\text { Factor }^{d} \\
\text { (mg/MJ) }\end{array}$ & \\
\hline $\mathrm{PM}_{10}$ & $106.5^{\mathrm{f}}$ & 2.85 & 70 & 2.67 & 0.135 \\
\hline VOCs & 44.2 & 1.18 & 60 & 2.29 & $0.155^{\mathrm{g}}$ \\
\hline $\mathrm{CO}$ & 560 & 14.98 & 400 & 15.25 & 0.41 \\
\hline $\mathrm{NO}_{2}$ & 2,240 & 59.91 & 2,300 & 8.77 & 1.896 \\
\hline $\mathrm{SO}_{2}$ & 9.6 & 0.026 & $2^{h}$ & $0.763^{\text {h }}$ & 0.126 \\
\hline
\end{tabular}

a Boilers with a rated heat input ranging from 10,560 to $105,600 \mathrm{MJ} / \mathrm{h}$.

b Boilers with a rated heat input ranging from 3 to $29 \mathrm{MW}$ using propane fuel.

c Based on an average natural gas higher heating value of $37.43 \mathrm{MJ} / \mathrm{m}^{3}$.

d Based on an average propane heating value of $26.23 \mathrm{MJ} / \mathrm{L}(94,000 \mathrm{Btu} / \mathrm{gal})$.

e Energy content of fuel input based on an average heat content of $38.23 \mathrm{MJ} / \mathrm{L}(137,000 \mathrm{Btu} / \mathrm{gal})$.

f Includes both filterable and condensable $\mathrm{PM}_{10}$.

g Includes exhaust, evaporative, crankcase, and refueling emissions.

h Based on $0.41 \mathrm{mg}$ sulfur $/ \mathrm{m}^{3}$ ( 0.18 grain $\left./ 100 \mathrm{ft}^{3}\right)$.

Source: EPA (1995a). 
range of boilers serving newly constructed NIF buildings. The natural gas emission factors are established as a mass $(\mathrm{kg})$ of pollutant emitted per unit of gas volume $\left(\mathrm{m}^{3}\right)$. To apply the emission factor to the fuel combustion energy demand listed in Tables 2.19 and 2.20, a conversion factor is introduced to convert emissions from a fuel volume basis $\left(\mathrm{m}^{3}\right)$ to an energy basis (MJ). The conversion factor is an assumed heat content for gas of $37.43 \mathrm{MJ} / \mathrm{m}^{3}$ (1,000 Btu/ft ${ }^{3}$ ) (EPA 1995a). This heat content assumption is valid because natural gas (methane) contains little impurities and, therefore, has a fairly constant heat content throughout the United States. The inclusion of both filterable and condensable $\mathrm{PM}_{10}$ refers to the sampling procedure used by EPA to develop the $\mathrm{PM}_{10}$ factors that are reported separately as "dry" and "condensable" catch in the sampling train.

Table 2.21 lists air pollutant emission factors for external combustion units (boilers) burning LPG (propane). The emission factors are a function of boiler size. The emission factors cited in Table 2.21 cover a very broad boiler size range of from 3 to $29 \mathrm{MW}$. Again, this range should be sufficient to include any boilers expected to be used for newly constructed NIF buildings (see Tables 2.19 and 2.20). NTS is the only candidate site indicating that LPG would be used to meet NIF energy demands (White 1995a). The LPG emission factors (EPA 1995a) are established as a mass (g) of pollutant emission per unit of LPG (propane) volume (L).

To apply the LPG (propane) emission factor to the fuel combustion energy demand in Tables 2.19 and 2.20 for NTS, a conversion factor was used to convert emissions from a volume basis (L) to an energy basis (MJ). The conversion factor is an assumed heat content of $26.23 \mathrm{MJ} / \mathrm{L}$ (94,000 Btu/gal) (EPA 1995a). This factor is judged to be valid because propane contains little impurities and, therefore, has a fairly constant heat content throughout the United States. Emissions of sulfur dioxide $\left(\mathrm{SO}_{2}\right)$ are based on an assumed propane sulfur content of $0.41 \mathrm{mg} / \mathrm{m}^{3}(0.18$ grain sulfur/100 $\mathrm{ft}^{3}$ ) (EPA 1995a).

Table 2.21 lists air pollutant emission factors (EPA 1995a) for stationary internal combustion engines of the size typically used for prime movers to drive standby electric generators. The emission factors cited are for the combustion of diesel fuel, as indicated in Table 2.19. The diesel engine emission factors are established as mass $(\mathrm{g})$ of pollutant emission per unit of energy content (MJ) of diesel fuel input. To apply the air pollutant emission factor to diesel fuel usage (L) requirements in Table 2.19, a conversion factor was introduced to convert emissions from a fuel volume basis to an energy basis. The conversion factor is an assumed average heat content for diesel fuel of 38.23 MJ/L (137,000 Btu/gal) (EPA 1995a).

\subsection{Source Operating Activity}

Operating air pollutant emission factors are expressed per unit of source activity. NIF air pollutant emission sources would be external combustion (boilers) and stationary internal combustion engines burning fossil fuels. The operating source activity of interest is fulfilling the 
energy demand that must be satisfied by burning fossil fuel. The estimates of NIF fossil fuel combustion operating emissions are based on design energy demand requirements for space heat, hot water, and maintenance operation of internal combustion engines used to drive standby electric generators. NIF design energy demand requirements are given in Table 2.19. As indicated in that table, slightly more than half the total space heat and hot water energy demand would be required for the Laser and Target Area Building, and the remainder would be required by the full complement of support buildings. Diesel fuel consumption for maintenance runs to drive standby electric generators reflects stand-by support for individual buildings.

All the facilities required to support NIF operations are identified in Table 2.22 (also see Section I.3.4 of the PSA [Appendix I of DOE 1996]). All sites would require construction of the Laser and Target Area Building; however, none of the sites would need to construct the full complement of support buildings. Only new construction would require additional fuel combustion for space heat and hot water. A conservative assumption is that the required energy demand of standby generators would be required for both existing buildings and new facilities.

Table 2.22 lists the area requirement for each support building. This information was used to adjust the total design support building complex energy demand of $19.5 \times 10^{6} \mathrm{MJ}$ to the energy demand required only for the new support buildings that would be constructed at a specific site. For each site, the ratio of the area of new buildings to the sum of the areas for the total support building complex identified in Table 2.22 was used to compute energy demand for new construction at each candidate site. The sum of the design support building complex area in Table 2.22 is $26,722 \mathrm{~m}^{2}$ $\left(287,643 \mathrm{ft}^{2}\right)$. Table 2.20 summarizes the information used to scale design support building energy demand to reflect only new building construction at each site.

At LLNL, for example, the area of new support building construction would be $1,858 \mathrm{~m}^{2}$ $\left(20,000 \mathrm{ft}^{2}\right)$, compared with the design areas of all NIF support buildings of $26,722 \mathrm{~m}^{2}\left(287,643 \mathrm{ft}^{2}\right)$ (Table 2.20). The ratio of LLNL new support building construction area size to the sum of all support building area sizes is, thus, $1,858 / 26,722$, or a scaling factor of 0.07 . Multiplying that scaling factor times the total support building design energy demand of $19.5 \times 10^{6} \mathrm{MJ} / \mathrm{yr}$ (Table 2.19) results in a NIF support building energy demand of $1.37 \times 10^{6} \mathrm{MJ} / \mathrm{yr}$ for LLNL (Table 2.20). This approach was used for all candidate sites. The new construction support building space heat and hot water energy demand determined for each site, as listed in Table 2.20, was then used to compute air pollutant emissions. The annual energy demand (MJ/yr) was multiplied by the emission factor (grams of pollutant per megajoule) to arrive at projected annual air pollutant emissions.

Detailed site-specific NIF operating emissions based on site-specific energy demand are listed in Tables 2.23 through 2.25. Tables 2.23 and 2.24 show a breakdown of operating emissions for the NIF Laser and Target Area Building. This facility would have to be constructed to design specifications at whatever site was selected for NIF. Therefore, Tables 2.23 and 2.24 are based on the same fossil fuel energy demand indicated in Table 2.19. Table 2.23 lists emissions that would 
TABLE 2.22 Facilities Required for National Ignition Facility Operations at Each Candidate Site

\begin{tabular}{|c|c|c|c|c|c|c|}
\hline Required Facility & $\begin{array}{l}\text { Size } \\
\text { Required } \\
\left(\mathrm{m}^{2}\right)\end{array}$ & LLNL & LANL & NTS & NLVF & SNL \\
\hline Laser and Target Area Bldg. & 16,722 & New facility & $\begin{array}{l}\text { New facility } \\
\text { TA-58 }\end{array}$ & New facility & New facility & New facility \\
\hline Target Receiving/Inspection & 1,393 & $\begin{array}{l}\text { B298 ICF Target Develop- } \\
\text { ment, Receiving, and } \\
\text { Inspection }\end{array}$ & TA-35-213 & New facility & $\begin{array}{l}\text { C-3 High Intensity } \\
\text { Source Laboratory }\end{array}$ & New facility \\
\hline Optics Assembly Area & 1,858 & $\begin{array}{l}\text { New facility and B391 } \\
\text { High Bay }\end{array}$ & $\begin{array}{l}\text { New facility } \\
\text { TA-58 }\end{array}$ & New facility & New facility & New facility \\
\hline General Assembly Area & 2,787 & $\begin{array}{l}\text { B166 ICF High Bay, B391 } \\
\text { High Bay }\end{array}$ & $\begin{array}{l}\text { New facility } \\
\text { TA-58 }\end{array}$ & $\begin{array}{l}\text { 6-800 Heavy Duty } \\
\text { Shop }\left(1,866 \mathrm{~m}^{2}\right) \\
6-624 \text { Heavy Duty } \\
\text { Shop }\left(1,187 \mathrm{~m}^{2}\right)\end{array}$ & A-1 High Bay & New facility \\
\hline Optics Maintenance Area & 3,716 & $\begin{array}{l}\text { B391 Nova, B321 Optics } \\
\text { Fabrication, B329 ICF } \\
\text { R\&D and Storage Area, } \\
\text { B432 High Bay and Optics } \\
\text { Meteorology Area, new } \\
\text { facility (same as Optics } \\
\text { Assembly Area) }\end{array}$ & $\begin{array}{l}\text { TA-3-287 } \\
\text { (upgrade) }\end{array}$ & New facility & New facility & New facility \\
\hline Optics Storage Area & 2,090 & $\begin{array}{l}\text { B392, ICF R\&D and } \\
\text { storage area, B494-381 } \\
\text { High Bay }\end{array}$ & $\begin{array}{l}\text { TA-3-105 } \\
\text { (upgrade) }\end{array}$ & New facility & New facility & New facility \\
\hline
\end{tabular}


TABLE 2.22 (Cont.)

\begin{tabular}{|c|c|c|c|c|c|c|}
\hline Required Facility & $\begin{array}{l}\text { Size } \\
\text { Required } \\
\left(\mathrm{m}^{2}\right)\end{array}$ & LLNL & LANL & NTS & NLVF & SNL \\
\hline Radiological Storage Area & 127 & B331 Tritium Facility & $\begin{array}{l}\text { Existing } \\
\text { Facility in } \\
\text { TA-54 }\end{array}$ & $\begin{array}{l}\text { Building } 610 \text { about } \\
3.2 \mathrm{~km} \text { from NIF } \\
\text { location }\end{array}$ & New facility & $\begin{array}{l}\text { Existing facility } \\
\text { in TA-III }\end{array}$ \\
\hline Office Building & 7,432 & B481 ICF Office Building & $\begin{array}{l}\text { TA-3-40 } \\
\text { TA-3-287 } \\
\text { TA-3-105 } \\
\text { TA-3-100 } \\
\text { New facility } \\
\left(1,860 \mathrm{~m}^{2}\right)\end{array}$ & $\begin{array}{l}\text { 23-117 A\&E Bldg. } \\
\left(2,104 \mathrm{~m}^{2}\right) \\
\text { 23-600 L.L. \& Eng. } \\
\left(3,498 \mathrm{~m}^{2}\right) \\
23-113 \text { REECo Trn. } \\
\left(962 \mathrm{~m}^{2}\right) \\
\text { 23-112 REECo } \\
\text { Safety }\left(889 \mathrm{~m}^{2}\right)\end{array}$ & $\begin{array}{l}\text { Conversion of B-1 } \\
\text { or new facility }\end{array}$ & $\begin{array}{l}\text { New facility and } \\
\text { shared space } \\
\left(3,716 \mathrm{~m}^{2}\right) \text { with } \\
\text { Buildings } 952 \\
\text { and } 960 \text { of } \\
\text { TA-IV }\end{array}$ \\
\hline $\begin{array}{l}\text { Electrical and Mechanical } \\
\text { Shops }\end{array}$ & 1,115 & $\begin{array}{l}\text { B511 Maintenance Shop, } \\
\text { B383 Machine Shop, B321 } \\
\text { Machine Shop }\end{array}$ & TA-3-39 & $\begin{array}{l}23-710 \text { Crafts Bldg. } \\
\left(1,919 \mathrm{~m}^{2}\right)\end{array}$ & A-1 Low Bay & $\begin{array}{l}\text { Building } 840 \text { of } \\
\text { TA-I }\end{array}$ \\
\hline Warehouse & 2,787 & $\begin{array}{l}\text { B041 Warehouse, B531 } \\
\text { Warehouse and other on- } \\
\text { site storage areas }\end{array}$ & $\begin{array}{l}\text { TA-3-30 } \\
\text { TA-3-142 }\end{array}$ & $\begin{array}{l}\text { 23-W1, W2, W3, W3A } \\
\text { (total } 2,787 \mathrm{~m}^{2} \text { ) W4, } \\
\text { W4A, W5 }\end{array}$ & A-2 Warehouse & New facility \\
\hline $\begin{array}{l}\text { Shipping, Receiving, and } \\
\text { Stores }\end{array}$ & 1,300 & B411 Central Stores & TA-3-30 & $\begin{array}{l}23-W 6\left(1,300 \mathrm{~m}^{2}\right) \\
W 5 A, W 7\end{array}$ & A-2 Warehouse & $\begin{array}{l}\text { Building } 857 \text { of } \\
\text { TA-I }\end{array}$ \\
\hline Medical Facility & 278 & B663 Medical Services & TA-43 & $\begin{array}{l}\text { 23-650 Medical } \\
\text { Facility }\end{array}$ & $\begin{array}{l}\text { C-1 Medical } \\
\text { Facility }\end{array}$ & $\begin{array}{l}\text { Building } 831 \text { of } \\
\text { TA-I }\end{array}$ \\
\hline Cafeteria & 743 & T4675 Central Cafeteria & TA-3-261 & 23-300 Cafeteria & C-1 Cafeteria & $\begin{array}{l}\text { Building } 861 \text { of } \\
\text { TA-I }\end{array}$ \\
\hline Garage, Gas Station & 223 & B611 Garage & TA-3-36 & 23-750 Fleet Service & $\begin{array}{l}\text { Not required on- } \\
\text { site }\end{array}$ & $\begin{array}{l}\text { Buildings } 873 \text {, } \\
874,875 \text {, and - } \\
876 \text { of TA-I }\end{array}$ \\
\hline
\end{tabular}




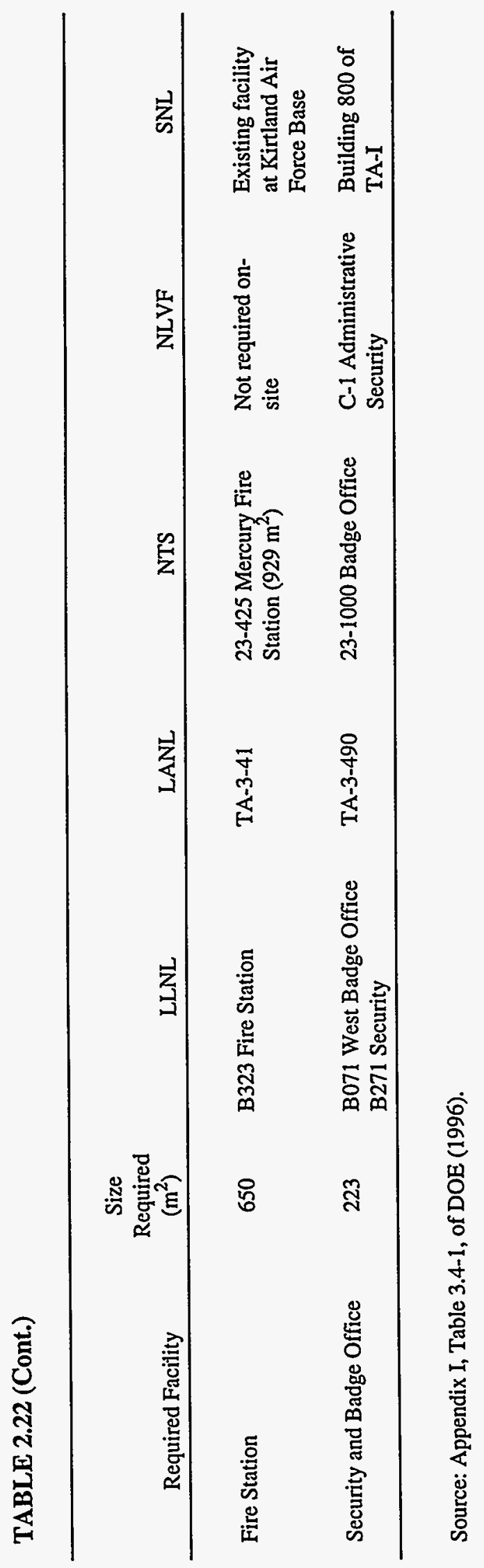


TABLE 2.23 Laser and Target Area Building Estimated Annual Fuel Combustion Emissions with Natural Gas ${ }^{\mathrm{a}}$

\begin{tabular}{|c|c|c|c|c|}
\hline \multirow[b]{2}{*}{ Pollutant } & \multicolumn{2}{|c|}{$\begin{array}{c}\text { Natural Gas-Fired External } \\
\text { Combustion Emissions }{ }^{\mathrm{b}} \text { (t/yr) }\end{array}$} & \multirow{2}{*}{$\begin{array}{c}\text { Diesel-Fired } \\
\text { Internal } \\
\text { Combustion } \\
\text { Stand-By-Power } \\
\text { Emissions (t/yr) }\end{array}$} & \multirow{2}{*}{$\begin{array}{l}\text { Total } \\
\text { Emissions } \\
(t / y r)\end{array}$} \\
\hline & $\begin{array}{l}\text { Space } \\
\text { Heat }\end{array}$ & $\begin{array}{l}\text { Domestic } \\
\text { Hot Water }\end{array}$ & & \\
\hline $\mathrm{PM}_{10}$ & 0.124 & 0.002 & 0.002 & 0.128 \\
\hline VOCs & 0.025 & $<0.001$ & 0.002 & $0.152^{c}$ \\
\hline $\mathrm{CO}$ & 0.317 & 0.005 & 0.005 & 0.327 \\
\hline $\mathrm{NO}_{2}$ & 1.267 & 0.019 & 0.023 & 1.309 \\
\hline $\mathrm{SO}_{2}$ & 0.005 & $<0.001$ & 0.002 & 0.007 \\
\hline Lead $^{d}$ & Negligible & Negligible & Negligible & Negligible \\
\hline \multicolumn{5}{|c|}{$\begin{array}{l}\text { Air pollutant emission estimates based on siting document design annual } \\
\text { energy use requirements (LLNL 1995b) and fuel-specific air pollution } \\
\text { emission factors cited in AP-42 (EPA 1995a). Applicable to all sites } \\
\text { burning natural gas (LLNL, LANL, NLVF, and SNL). }\end{array}$} \\
\hline \multicolumn{5}{|c|}{$\begin{array}{l}\text { Emission factors selected to represent emissions from external combustion } \\
\text { units rated at from } 10,560 \text { to } 105,600 \mathrm{MJ} / \mathrm{h} \text {, assuming no pollutant } \\
\text { controls. }\end{array}$} \\
\hline \multicolumn{5}{|c|}{$\begin{array}{l}\text { Includes } 0.125 \mathrm{t} / \mathrm{yr} \text { VOCs (primarily ethanol) from cleaning with solvents } \\
\text { (LLNL 1995b). }\end{array}$} \\
\hline
\end{tabular}

be applicable to all sites that would use natural gas as the fuel of choice for external combustion (boiler) air pollutant emissions (LLNL, LANL, NLVF, and SNL). Table 2.24 lists emissions that would be applicable to NTS, which specified that its fuel of choice for space heat and hot water, based on the Table 2.19 energy demand, is LPG (assumed to be propane) (White 1995b).

Detailed support building operating air pollutant emissions for each site are presented in Table 2.25. Emissions vary among sites on the basis of the number and size of new support buildings that would require space heat and hot water. All external combustion emissions are based on burning natural gas, except for those at NTS Area 22, where LPG would be used. 
TABLE 2.24 Laser and Target Area Building Estimated Annual Fuel Combustion Emissions with LPG (Propane) ${ }^{a}$

\begin{tabular}{|c|c|c|c|c|}
\hline \multirow[b]{2}{*}{ Pollutant } & \multicolumn{2}{|c|}{$\begin{array}{c}\text { LPG-Fired External } \\
\text { Combustion Emissions (t/yr) }\end{array}$} & \multirow{2}{*}{$\begin{array}{c}\text { Diesel-Fired } \\
\text { Internal Combustion } \\
\text { Standby Power } \\
\text { Emissions } \\
(\mathrm{t} / \mathrm{yr}) \\
\end{array}$} & \multirow{2}{*}{$\begin{array}{c}\text { Total } \\
\text { Emissions } \\
(\mathrm{t} / \mathrm{yr})\end{array}$} \\
\hline & $\begin{array}{c}\text { Space } \\
\text { Heat }\end{array}$ & $\begin{array}{l}\text { Domestic } \\
\text { Hot Water }\end{array}$ & & \\
\hline $\mathrm{PM}_{10}$ & 0.058 & 0.005 & 0.002 & 0.065 \\
\hline VOCs & 0.048 & $<0.001$ & 0.002 & $0.175^{b}$ \\
\hline $\mathrm{CO}$ & 0.308 & 0.005 & 0.005 & 0.318 \\
\hline $\mathrm{NO}_{2}$ & 1.830 & 0.030 & 0.023 & 1.883 \\
\hline $\mathrm{SO}_{2}$ & 0.002 & $<0.001$ & 0.002 & 0.004 \\
\hline Lead $^{c}$ & Negligible & Negligible & Negligible & Negligible \\
\hline
\end{tabular}

a Air pollutant emission estimates based on siting document design annual energy use requirements (LLNL 1995b) and fuel-specific air pollution emission factors cited in AP-42 (EPA 1995a).

$\mathrm{b}$ Includes $0.125 \mathrm{t} / \mathrm{yr}$ VOCs (primarily ethanol) from cleaning with solvents (LLNL 1995b).

c No emission factors cited, assumed negligible.

TABLE 2.25 Estimated Fuel Combustion Emissions with Natural Gas for National Ignition Facility Support Facilities at LLNL, LANL, NLVF, and SNL

\begin{tabular}{lccc}
\hline & Diesel Internal & \\
Pollutant & $\begin{array}{c}\text { Neatural Gas Space } \\
\text { Combustion } \\
\text { Emissions }\end{array}$ & $\begin{array}{c}\text { Standby Power } \\
\text { Emissions } \\
\text { (t/yr) }\end{array}$ & $\begin{array}{c}\text { Total } \\
\text { Emissions } \\
(\mathrm{t} / \mathrm{yr})\end{array}$ \\
\hline $\mathrm{LLNL}^{\mathrm{b}}$ & & & \\
$\mathrm{PM}_{10}$ & 0.008 & 0.027 & 0.035 \\
$\mathrm{VOCs}_{\mathrm{CO}}$ & 0.002 & 0.036 & $0.413^{\mathrm{c}}$ \\
$\mathrm{NO}$ & 0.02 & 0.091 & 0.111 \\
$\mathrm{SO}_{2}$ & 0.082 & 0.399 & 0.481 \\
Lead $^{\mathrm{d}}$ & $<0.001$ & 0.027 & 0.027 \\
& Negligible & Negligible & Negligible
\end{tabular}




\begin{tabular}{|c|c|c|c|}
\hline Pollutant & $\begin{array}{l}\text { Natural Gas Space } \\
\text { Heat and Hot Water } \\
\text { Emissions }^{\mathrm{a}}(\mathrm{t} / \mathrm{yr})\end{array}$ & $\begin{array}{l}\text { Diesel Internal } \\
\text { Combustion } \\
\text { Standby Power } \\
\text { Emissions } \\
(\mathrm{t} / \mathrm{yr})\end{array}$ & $\begin{array}{c}\text { Total } \\
\text { Emissions } \\
(\mathrm{t} / \mathrm{yr})\end{array}$ \\
\hline \multicolumn{4}{|l|}{ LANL $^{b}$} \\
\hline $\mathrm{PM}_{10}$ & 0.02 & 0.027 & 0.047 \\
\hline VOCs & 0.005 & 0.036 & $0.416^{\mathrm{c}}$ \\
\hline $\mathrm{CO}$ & 0.056 & 0.091 & 0.147 \\
\hline $\mathrm{NO}_{2}$ & 0.205 & 0.399 & 0.604 \\
\hline $\mathrm{SO}_{2}$ & 0.001 & 0.027 & 0.028 \\
\hline Lead $^{d}$ & Negligible & Negligible & Negligible \\
\hline \multicolumn{4}{|l|}{$\mathrm{NLVF}^{\mathrm{b}}$} \\
\hline $\mathrm{PM}_{10}$ & 0.056 & 0.027 & 0.083 \\
\hline VOCs & 0.011 & 0.036 & $0.424^{c}$ \\
\hline $\mathrm{CO}$ & 0.144 & 0.091 & 0.235 \\
\hline $\mathrm{NO}_{2}$ & 0.577 & 0.401 & 0.978 \\
\hline $\mathrm{SO}_{2}$ & 0.003 & 0.027 & 0.03 \\
\hline Lead $^{d}$ & Negligible & Negligible & Negligible \\
\hline \multicolumn{4}{|l|}{$S_{N L}^{b}$} \\
\hline $\mathrm{PM}_{10}$ & 0.043 & 0.027 & 0.07 \\
\hline VOCs & 0.009 & 0.036 & $0.420^{c}$ \\
\hline $\mathrm{CO}$ & 0.110 & 0.091 & 0.201 \\
\hline $\mathrm{NO}_{2}$ & 0.440 & 0.399 & 0.839 \\
\hline $\mathrm{SO}_{2}$ & 0.002 & 0.027 & 0.029 \\
\hline Lead $^{d}$ & Negligible & Negligible & Negligible \\
\hline
\end{tabular}

a Emission factors selected to represent emissions from external combustion units rated from 10,560 to $105,600 \mathrm{MJ} / \mathrm{h}$, assuming no pollutant controls.

b Air pollutant emission estimates based on siting document design annual energy use requirements (LLNL 1995b) adjusted to represent new support building construction energy demand for $1,858 \mathrm{~m}^{2}$ new building area size for LLNL, $4,645 \mathrm{~m}^{2}$ for LANL, $13,133 \mathrm{~m}^{2}$ for NLVF, and $9,988 \mathrm{~m}^{2}$ for SNL. Fuel-specific air pollution emission factors cited in AP-42 (EPA 1995a) were used to compute emissions.

c Includes $0.375 \mathrm{t} / \mathrm{yr}$ VOCs (primarily ethanol) from cleaning with solvents (LLNL 1995b).

d No emission factor cited, assumed negligible. 


\subsection{ANALYSIS OF ACOUSTICAL IMPACTS}

This section provides data supporting impact assessments for acoustics presented in Chapter I.4 of the NIF PSA (Appendix I, DOE 1996). Included below are a description of the analytical methods used, discussion of assumptions used in the analyses, and summaries of the results for each of the candidate NIF sites.

\subsubsection{Modified Composite Noise Rating}

To evaluate the acoustical impacts from the construction equipment moving around a construction site, one conceptually places each piece of equipment at its most representative spot for a "worst day." Among all the metrics that have been used to represent noise impacts from fixed construction or operational sources, the Modified Composite Noise Rating (Modified CNR) has been commonly accepted by both industry and regulatory bodies (EEI 1984). The Modified CNR approach to noise impact evaluation has the following advantages:

- Provides a single value descriptor of impact;

- Considers the community's experience with noise;

- Considers community attitude toward the source;

- Accounts for existing background sound levels;

- Accounts for the frequency content of both the existing sound level and the added sound;

- Accounts for impulse, tonal, and low-frequency sound; and

- Accounts for duration, time of day, and time of year of the added sound.

The Modified CNR can be used with both short-term and long-term sound exposures, unlike other methods such as the annual average day-night sound level $\left(\mathrm{L}_{\mathrm{dn}}\right)$.

Application of the Modified CNR requires the following information:

- Noise contribution of the new sound sources from the proposed action, as octave-band spectra,

- Octave-band spectra of baseline sound levels, 
- Information on community noise experience, and

- Identification of receptors and locations.

Responses to the new noise sources at a given receptor location are evaluated on the basis of composite noise ratings of A through I, as part of the modified CNR method. Levels A through C imply no reaction, and levels higher than $\mathrm{C}$ lead to increasing expectation of noise impacts at a given receptor. The calculational model and evaluations are applied at each receptor location separately.

For greatest accuracy of the noise impact determination, it is preferable to use data from site measurements of baseline sound level; however, often such data are not available. Because appropriate data must be obtained over a long period and be representative of various times of day, days of the week, and seasons, they cannot be obtained by direct measurement in timely fashion. Alternative sources of baseline data include results of measurements at similar locations or analyses of databases containing results of measurements at many locations at various times.

For this analysis, measured data from representative noise sources were used. Selection of some baseline spectra was based on $\mathrm{L}_{\mathrm{dn}}$ information from Tables 2.26 and 2.27. The appropriate spectrum was selected from various sources of measured data. The selection process consisted of choosing an $L_{d n}$, then selecting the most appropriate spectrum. The $L_{d n}$ measure accounts for temporal difference in human response to noise, with nighttime noise considered more "annoying" than daytime noise of the same absolute magnitude. When the $L_{d n}$ value is computed, a 10-dB "penalty" is added to the average nighttime noise level to account for this factor. Thus, in the case when the average nighttime sound level is $10 \mathrm{~dB}$ less than the average daytime level, the $\mathrm{Ld}_{\mathrm{n}}$ value will be the average daytime level. For this analysis, if a spectrum was found that was appropriate from the standpoint of the type of environment represented, but was not consistent with the appropriate $L_{d n}$ value, the spectrum was adjusted uniformly to correspond to the desired $A$-weighted level.

TABLE 2.26 Estimated Percentage of Urban Population ${ }^{\mathrm{a}}$ Residing in Areas with Various Day-Night Noise Levels $\left(\mathbf{L}_{\mathbf{d n}}\right)$

\begin{tabular}{lccccc}
\hline & \multicolumn{2}{c}{$\mathrm{L}_{\mathrm{dn}}(\mathrm{dB})$} & & \\
\cline { 2 - 3 } \multicolumn{1}{c}{ Description } & $\begin{array}{c}\text { Typical } \\
\text { Range }\end{array}$ & $\begin{array}{c}\text { Average } \\
\text { Estimated }\end{array}$ & $\begin{array}{c}\text { Estimated } \\
\text { Percentage of } \\
\text { Urban Population }\end{array}$ & $\begin{array}{c}\text { Average Census } \\
\text { Tract Population } \\
\left.\text { (number/km }{ }^{2}\right)\end{array}$ \\
\hline Quiet suburban residential & $48-52$ & 50 & 12 & 243 \\
Normal suburban & $53-57$ & 55 & 21 & 772 \\
Urban residential & $58-62$ & 60 & 28 & 2,432 \\
Noisy urban residential & $63-67$ & 65 & 19 & 7,720 \\
Very noisy urban residential & $68-72$ & 70 & 7 & 24,318 \\
\hline
\end{tabular}

a Total urban population is 134 million.

Source: EPA (1974). 
TABLE 2.27 Typical Yearly Day-Night

Average Sound Levels $\left(L_{d n}\right)$ for

Neighborhoods with No Well-Defined

Source of Noise other than Usual

Transportation Noise

\begin{tabular}{lcc}
\hline & $\begin{array}{c}\text { Population } \\
\text { Density }\end{array}$ & $\mathrm{L}_{\mathrm{dn}}$ \\
Neighborhood Type & $\begin{array}{c}\text { (people/km }{ }^{2} \text { ) } \\
(\mathrm{dB})\end{array}$ \\
\hline Rural & & \\
Undeveloped & 8 & 35 \\
Partially developed & 23 & 40 \\
Quiet suburban & 77 & 45 \\
Normal suburban & 240 & 50 \\
Urban & 770 & 55 \\
Noisy urban & 2,300 & 60 \\
Very noisy urban & 7,700 & 65 \\
\hline
\end{tabular}

Adapted from National Research Council (1971).

Octave-band spectra of the sound levels expected at various receptor locations were computed using the modified CNR method that incorporates evaluation of the dispersion of sound by propagation over distance and attenuation of sound by interaction with the air. Insufficient data were available to justify use of a more sophisticated model that would evaluate the effect of barriers, absorption of sound by the ground surface, and atmospheric effects. Omitting these factors is not expected to substantially change the comparative evaluation of the five candidate NIF sites.

Source terms used in the spreadsheet model include (1) sound power of equipment, (2) sound propagation path length based on representative location of equipment, and (3) location of identified receptors.

Data on equipment sound power levels were obtained from supporting documentation for assessment of alternative sites for a high-level nuclear waste repository (Liebich and Policastro 1986). The sound power data are shown in Table 2.28. The following assumptions were made in modeling noise expected from the construction of NIF:

1. The distance from the center of the proposed facility to each of the identified receptors was the same as the distance used in the analysis of radiological and other emissions. 
TABLE 2.28 Sound Power Levels of Equipment Modeled for Analysis of Noise Impact during National Ignition Facility Construction Phase

Octave Band Frequency $(\mathrm{Hz})$ at Various Sound Power Levels

(dB) (re: $1 \mathrm{pw})$

\begin{tabular}{lrrrrrrrr}
\cline { 2 - 8 } \multicolumn{1}{c}{ Item } & 32 & 63 & 125 & 500 & 1,000 & 2,000 & 4,000 & 8,000 \\
\hline & 107 & 108 & 109 & 109 & 109 & 106 & 101 & 97 \\
Loader & 102 & 109 & 116 & 110 & 108 & 106 & 100 & 94 \\
Water truck & 124 & 130 & 125 & 122 & 113 & 108 & 102 & 98 \\
D8 Caterpillar tractor & 100 & 104 & 114 & 111 & 108 & 106 & 101 & 97 \\
Grader & & & & & & & &
\end{tabular}

2. Distances from individual equipment items to each receptor location were scaled from appropriate maps and drawings.

3. The activity creating the greatest amount of noise would be the clearing of the site and removal of spoil.

4. The following equipment would be used in the clearing and removal of spoil (excavating, hauling, and placing earth):

a. Four diesel-powered bottom-load-and-dump haulers, used to excavate and haul earth,

b. Two D-8 Caterpillar bulldozers used to move earth and push haulers during the loading operation,

c. Two water trucks used to control dust during excavation and placement of spoil, and

d. Two graders used to bring the site to grade following excavation.

5. Spoil would be stored on-site, or in off-site areas immediately adjacent to the boundary of the host facility, thus minimizing the length of the haul route.

6. In the model, the deployment of equipment is essentially the same for each site, with slight variations for site shape. Typically, two of the four haulers are deployed on the excavation site, one is en route between the excavation site and the spoil pile, and one is at the spoil pile. The two bulldozers are located proximal to the two haulers at the excavation area. One water tank truck is at the excavation and one is at the spoil pile. The two graders are in different 
parts of the excavation area. Depending on the location of the receptor being modeled, the distance from each noise source to the receptor can differ substantially from the distance between the site center and the receptor.

For the Modified CNR analysis of noise effects, it was assumed that the site-clearing phase would occur during the summer. Since the summer is the time when more people are outdoors and doors and windows are more likely to be open, this season represents the greatest potential for noise impact.

The temperature and relative humidity values used in modeling air attenuation of sound were $15^{\circ} \mathrm{C}\left(59^{\circ} \mathrm{F}\right)$ and $70 \%$, respectively. The values of attenuation (in $\mathrm{dB} / 100 \mathrm{~m}[\mathrm{~dB} / 328 \mathrm{ft}]$ ) used are shown in Table 2.29. The relative humidity may appear to be high, especially for locations like SNL and LANL; however, such conditions apply to times when sound-level impact may be the greatest and are within the range of accuracy established by the use of assumed values for baseline sound levels.

\subsubsection{Assumptions and Results for Composite Noise Rating Analysis}

The various adjustment criteria applied in the CNR analysis are summarized in Table 2.30. Community noise experience factors used to adjust the modified CNR results were based on the

TABLE 2.29 Sound Attenuation Rates for Molecular Absorption for "Standard Day" Conditions and for "Anomalous Excess Attenuation"

\begin{tabular}{cccc}
\hline $\begin{array}{c}\text { Octave } \\
\begin{array}{c}\text { Frequency } \\
\text { Band } \\
(\mathrm{Hz})\end{array}\end{array}$ & $\begin{array}{c}\text { Molecular Absorption } \\
\text { at } 59^{\circ} \mathrm{F}, 70 \% \text { R.H. } \\
(\mathrm{dB} / 100 \mathrm{~m})\end{array}$ & $\begin{array}{c}\text { Anomalous } \\
\text { Excess } \\
\text { Attenuation } \\
(\mathrm{dB} / 100 \mathrm{~m})\end{array}$ & $\begin{array}{c}\text { Suggested Total } \\
\text { Attenuation for } \\
\text { Standard Day } \\
(\mathrm{dB} / 100 \mathrm{~m})\end{array}$ \\
\hline 32 & - & 0.10 & 0.10 \\
63 & 0.03 & 0.13 & 0.16 \\
125 & 0.07 & 0.20 & 0.27 \\
250 & 0.13 & 0.26 & 0.39 \\
500 & 0.23 & 0.36 & 0.59 \\
1,000 & 0.49 & 0.49 & 0.98 \\
2,000 & 0.98 & 0.72 & 1.70 \\
4,000 & 2.49 & 0.98 & 3.47 \\
8,000 & 4.49 & 1.31 & 5.80 \\
\hline
\end{tabular}

a Values obtained by adding columns 2 and 3. 
assumption that in the case of each of the sites except NTS, community members have a strong association with, and thus a favorable attitude toward, the proposed action through their involvement with facilities presently at the site (such as various DOE laboratories). Since an assumption regarding previous experience with noise could not be made in the same manner, it was assumed that the residents of each of the urban communities has had some previous exposure to noise of the type expected. Because NTS does not appear to have a community structure nearby, the response adjustment factors for that analysis were considered to be neutral. Results of the Modified CNR evaluations for each candidate site are summarized in Tables 2.31 through 2.35.

Examination of the noise impact of site clearing in terms of annual noise exposure helps put the impact in perspective. Although site clearing would be the activity of highest noise emission that would occur at any of the candidate sites, the duration of this activity would be relatively short (on the order of four weeks). The temporary nature of high sound levels from this construction phase would mitigate the severity of any noise responses predicted by the Modified CNR process. The level of noise from other construction activities would be expected to be smaller in magnitude.

Noise resulting from operation of the facility is expected to consist of continuous low-level sound from heating, ventilation, and air conditioning equipment. A source of related noise is expected to be a nominal increase in traffic noise associated with the vehicles of commuting staff and from occasional delivery of materials. 
TABLE 2.30 Normalizing Factors for Composite Noise Rating Results

Type and Description of Adjustment to Noise Rank

Factor $^{\mathrm{a}}$

Seasonal correction

Summer or year-round operation

Winter-only operation

Adjustment for outdoor baseline sound level

Quiet suburban

$+2$

Normal suburban (no industrial activity)

$+1$

Urban residential (no high-traffic areas)

0

Noisy urban residential (nearby traffic)

$-1$

Very noisy urban residential

Prior experience with noise and community attitude

No prior experience with noise or some prior experience but poor community relations

Some previous experience and good community relations

Considerable previous exposure and good community relations

Noise character

Low frequency present

$+1$

Tonal components present

$+1$

Impulsive sound present

Intermittency of sound, percent of total time sound present

$100-57$

$56-18$

$17-6$

$5-1.8$

0

$1.7-0.57$

$-2$

$1.7-0.57$
$0.56-0.01$

$-3$

$-4$

$-5$

a Factors represent units on the modified CNR scale relating to human reaction. 
TABLE 2.31 Summary of Modeling and Analysis - Lawrence

\section{Livermore National Laboratory}

\begin{tabular}{|c|c|c|c|}
\hline Parameter & Residential & Laboratory & $\mathrm{MEI}^{\mathrm{a}}$ \\
\hline \multicolumn{4}{|l|}{ Background level } \\
\hline Day-night level (dBA) & 60 & 55 & 55 \\
\hline Daytime level (dBA) & 61 & 55 & 55 \\
\hline Nighttime level (dBA) & 48 & 45 & 45 \\
\hline CNR rank & -3 & -2 & -2 \\
\hline \multicolumn{4}{|l|}{ Construction contribution } \\
\hline A-weighted level (dBA) & 43 & 57 & 69 \\
\hline CNR rank before adjustment & $\mathrm{C}$ & $\mathrm{F}$ & $G$ \\
\hline Combined level at receptor & 61 & 59 & 69 \\
\hline Increase in level (dBA) & 1 & 4 & 14 \\
\hline \multicolumn{4}{|l|}{ Adjustments } \\
\hline Background & -3 & -2 & -2 \\
\hline Temporal & -1 & -1 & -1 \\
\hline Seasonal & 0 & 0 & 0 \\
\hline Intermittency & 0 & 0 & 0 \\
\hline Low frequency & 0 & 0 & 0 \\
\hline Tonal content & +1 & +1 & +1 \\
\hline Impulsive noise & 0 & 0 & 0 \\
\hline Experience with noise & -0.5 & -0.5 & +0.5 \\
\hline Attitude toward project & -0.5 & -0.5 & +0.5 \\
\hline Total adjustment & -4 & -4 & -1 \\
\hline \multicolumn{4}{|l|}{ Results of CNR analysis } \\
\hline Adjusted rank & A & B & F \\
\hline Likelihood of complaints & None & None & Certain \\
\hline
\end{tabular}

a Maximally exposed individual east of Greenville Road, located $800 \mathrm{~m}$ east of Target Area. 
TABLE 2.32 Summary of Modeling and Analysis - Los Alamos National Laboratory

\begin{tabular}{|c|c|c|}
\hline Parameter & Laboratory & $\mathrm{MEI}^{\mathrm{a}}$ \\
\hline \multicolumn{3}{|l|}{ Background level } \\
\hline Day-night level (dBA) & 40 & 40 \\
\hline Daytime level (dBA) & 40 & 40 \\
\hline Nighttime level (dBA) & 35 & 35 \\
\hline CNR rank & 0 & 0 \\
\hline \multicolumn{3}{|l|}{ Construction contribution } \\
\hline A-weighted level (dBA) & 54 & 44 \\
\hline CNR rank before adjustment & $\mathrm{E}$ & $\mathrm{C}$ \\
\hline Combined level at receptor & 54 & 46 \\
\hline Increase in level (dBA) & 14 & 6 \\
\hline \multicolumn{3}{|l|}{ Adjustments } \\
\hline Background & 0 & +1 \\
\hline Temporal & 0 & 0 \\
\hline Seasonal & 0 & 0 \\
\hline Intermittency & 0 & 0 \\
\hline Low frequency & 0 & 0 \\
\hline Tonal content & 0 & .0 \\
\hline Impulsive noise & 0 & 0 \\
\hline Experience with noise & -0.5 & -5 \\
\hline Attitude toward project & -0.5 & -5 \\
\hline Total adjustment & 0 & 0 \\
\hline \multicolumn{3}{|l|}{ Results of CNR analysis } \\
\hline Adjusted rank & D & D \\
\hline Likelihood of complaints & Sporadic & Sporadic \\
\hline
\end{tabular}

a Maximally exposed individual, located $1,670 \mathrm{~m}$ northnortheast of Target Area. 
TABLE 2.33 Summary of Modeling and Analysis Nevada Test Site

\begin{tabular}{|c|c|c|}
\hline Parameter & Residential & Laboratory \\
\hline \multicolumn{3}{|l|}{ Background level } \\
\hline Day-night level (dBA) & 28 & 28 \\
\hline Daytime level (dBA) & 28 & 28 \\
\hline Nighttime level (dBA) & 19 & 19 \\
\hline CNR rank & +2 & +2 \\
\hline \multicolumn{3}{|l|}{ Construction contribution } \\
\hline A-weighted level (dBA) & 0 & 40 \\
\hline CNR rank before adjustment & NA & $\mathrm{B}$ \\
\hline Combined level at receptor & 28 & 40 \\
\hline Increase in level (dBA) & 0 & 12 \\
\hline \multicolumn{3}{|l|}{ Adjustments } \\
\hline Background & +2 & +2 \\
\hline Temporal & 0 & 0 \\
\hline Seasonal & 0 & 0 \\
\hline Intermittency & 0 & 0 \\
\hline Low frequency & 0 & 0 \\
\hline Tonal content & 0 & 0 \\
\hline Impulsive noise & 0 & 0 \\
\hline Experience with noise & 0 & 0 \\
\hline Attitude toward project & 0 & -1 \\
\hline Total adjustment & +2 & +1 \\
\hline \multicolumn{3}{|l|}{ Results of CNR analysis } \\
\hline Adjusted rank & NA & C \\
\hline Likelihood of complaints & NA & Sporadic \\
\hline
\end{tabular}


TABLE 2.34 Summary of Modeling and Analysis - North Las Vegas Facility

\begin{tabular}{|c|c|c|c|}
\hline Parameter & $\begin{array}{c}\text { Closest } \\
\text { Residential } \\
\text { Area }\end{array}$ & Laboratory & $\begin{array}{c}\text { Alternative } \\
\text { Residential } \\
\text { Area }\end{array}$ \\
\hline \multicolumn{4}{|l|}{ Background Level } \\
\hline Day-night level (dBA) & 66 & 60 & 66 \\
\hline Daytime level (dBA) & 66 & 60 & 66 \\
\hline Nighttime level (dBA) & 56 & 50 & 56 \\
\hline CNR rank & -6 & -5 & -6 \\
\hline \multicolumn{4}{|l|}{ Construction contribution } \\
\hline A-weighted level (dBA) & 83 & 70 & 74 \\
\hline CNR rank before adjustment & $\mathrm{J}$ & $\mathrm{H}$ & $\mathrm{H}$ \\
\hline Combined level at receptor & 83 & 70 & 74 \\
\hline Increase in level (dBA) & 17 & 10 & 8 \\
\hline \multicolumn{4}{|l|}{ Adjustments } \\
\hline Background & -6 & -5 & -6 \\
\hline Temporal & -1 & -1 & -1 \\
\hline Seasonal & 0 & 0 & 0 \\
\hline Intermittency & 0 & 0 & 0 \\
\hline Low frequency & 0 & 0 & 0 \\
\hline Tonal content & 1 & 1 & 1 \\
\hline Impulsive noise & 0 & 0 & 0 \\
\hline Experience with noise & -0.5 & -0.5 & -0.5 \\
\hline Attitude toward project & -0.5 & -0.5 & -0.5 \\
\hline Total adjustment & -7 & -7 & -7 \\
\hline \multicolumn{4}{|l|}{ Results of CNR analysis } \\
\hline Adjusted rank & $\mathrm{C}$ & A & A \\
\hline Likelihood of complaints & Sporadic & None & None \\
\hline
\end{tabular}


TABLE 2.35 Summary of Modeling and Analysis - Sandia National Laboratories

\begin{tabular}{|c|c|c|c|}
\hline Parameter & Residential & Laboratory & $\mathrm{MEI}^{\mathrm{a}}$ \\
\hline \multicolumn{4}{|l|}{ Background level } \\
\hline Day-night level (dBA) & 63 & 64 & 64 \\
\hline Daytime level (dBA) & 63 & 64 & 64 \\
\hline Nighttime level (dBA) & 53 & 54 & 54 \\
\hline CNR rank & -4 & -4 & -5 \\
\hline \multicolumn{4}{|l|}{ Construction contribution } \\
\hline A-weighted level (dBA) & 44 & 54 & 61 \\
\hline CNR rank before adjustment & $\mathrm{D}$ & $\mathrm{E}$ & $\mathrm{G}$ \\
\hline Combined level at receptor & 63 & 64 & 65 \\
\hline Increase in level (dBA) & 0 & 0 & 1 \\
\hline \multicolumn{4}{|l|}{ Adjustments } \\
\hline Background & -4 & -5 & -5 \\
\hline Temporal & 0 & 0 & 0 \\
\hline Seasonal & 0 & 0 & 0 \\
\hline Intermittency & 0 & 0 & 0 \\
\hline Low frequency & 0 & 0 & 0 \\
\hline Tonal content & 0 & 0 & 0 \\
\hline Impulsive noise & 0 & 0 & 0 \\
\hline Experience with noise & -0.5 & -0.5 & -0.5 \\
\hline Attitude toward project & -0.5 & -0.5 & -0.5 \\
\hline Total adjustment & -5 & -6 & -6 \\
\hline \multicolumn{4}{|l|}{ Results of CNR analysis } \\
\hline Adjusted rank & A & $\mathrm{A}$ & A \\
\hline Likelihood of complaints & None & None & None \\
\hline
\end{tabular}

a Maximally exposed individual, located $1,864 \mathrm{~m}$ north of Target Area. 


\subsection{REFERENCES FOR SECTION 2}

ABCAQCB — See Albuquerque-Bernalillo County Air Quality Control Board.

Albuquerque-Bernalillo Air Quality Control Board, 1973, Ambient Air Quality Standards, Albuquerque, N.M., May 21.

Bair, F.E., 1992, The Weather Almanac, 6th ed., Gales Research Inc., Detroit, Mich.

California Environmental Protection Agency Air Resources Board, 1993, California Air Quality Data, Summary of 1993 Air Quality Data, Gaseous and Particulate Pollutants, Vol. XXV, Sacramento, Calif.

CARB - See California Environmental Protection Agency Air Resources Board.

Caterpillar, Inc., 1992, Caterpillar Performance Handbook, 23rd ed., Oct.

DBHCC - See District Board of Health of Clark County.

DeBoisblance, W., 1995, personal communication from DeBoisblance (Bay Area Air Quality Management District, San Francisco, Calif.) to R. Haffenden and M. Monarch (Argonne National Laboratory, Argonne, Ill.), Aug. 15.

District Board of Health of Clark County, 1993, Air Pollution Regulations, Sèction 11 -Ambient Air Quality Standards, Clark County, Las Vegas, Nev., May 27.

DOE - See U.S. Department of Energy.

Edison Electric Institute, 1984, Electric Power Plant Environmental Noise Guide, prepared by Bolt Beranek and Newman Inc., Cambridge, Mass.

EEI - See Edison Electric Institute

EPA - See U.S. Environmental Protection Agency.

Foley, R., 1995, letter from Foley (Lawrence Livermore National Laboratory, Livermore, Calif.) to J. Hoffecker (Argonne National Laboratory, Argonne, Ill.), June 30.

Holzworth, G.C., 1972, Mixing Heights, Wind Speeds, and Potential for Urban Air Pollution Throughout the Contiguous United States, AP-101, U.S. Environmental Protection Agency, Office of Air Programs, Jan.

LANL — See Los Alamos National Laboratory. 
Lawrence Livermore National Laboratory, 1994, National Ignition Facility Siting Proposal, UCRL-PROP-1 19353, L-18862-1, Livermore, Calif., Dec.

Lawrence Livermore National Laboratory, 1995a, unpublished meteorological data for 1994, transmittal from F. Govenia (Lawrence Livermore National Laboratory, Livermore, Calif.) to A. Policastro (Argonne National Laboratory, Argonne, Ill.), July.

Lawrence Livermore National Laboratory, 1995b, National Ignition Facility Site Requirements, NIF-LLNL-93-089, L-16083-1, Livermore, Calif., July.

Lazaroff, G., 1995, facsimile from Lazaroff (EG\&G, North Las Vegas Facility, Las Vegas, Nev.) to J. Pfingston (Argonne National Laboratory, Argonne, Ill.), July 31.

Liebich, R., and A. Policastro, 1986, Unpublished information, Argonne National Laboratory, Argonne, Ill., Sept.

LLNL - See Lawrence Livermore National Laboratory.

Los Alamos National Laboratory, 1995, unpublished meteorological data for 1994, transmittal from G. Stone (Los Alamos National Laboratory, Los Alamos, N.M.) to Y.S. Chang (Argonne National Laboratory, Argonne, Ill), July.

Muleski, G., 1995, personal communication from Muleski (Midwest Research Institute, Kansas City, Mo.) to Y.S. Chang (Argonne National Laboratory, Argonne, Ill.), Nov. 6.

Nalco Chemical Company, 1987, Questions and Answers, Road Dust Control, Naperville, Ill.

National Research Council, 1971, Guidelines for Preparing Environmental Impact Statements on Noise, National Research Council, National Academy of Sciences, Washington, D.C.

NDEP - See Nevada Division of Environmental Protection.

Nevada Division of Environmental Protection, 1988-1992, Trend Report, Bureau of Air Quality, Carson City, Nev.

New Mexico Air Quality Bureau, 1994, New Mexico Air Quality, 1991-1993, NMED/AQB-94/1, New Mexico Environmental Department, Santa Fe, N.M.

New Mexico Environmental Improvement Board, 1981, Ambient Air Quality Standards, Air Quality Control Regulations 201, Santa Fe, N.M., June 15.

NMAQB — See New Mexico Air Quality Bureau. 
NMEIB - See New Mexico Environmental Improvement Board.

Nowinski, R., 1993, transmittal from Nowinski (John Ford's Ford Truck Sales, Inc., Lyons, Ill.) to K.C. Chun (Argonne National Laboratory, Argonne, Ill.), Aug. 20.

Richardson, C., 1995, personal communication from Richardson (Los Alamos National Laboratory, Los Alamos, N.M.) to J. Pfingston (Argonne National Laboratory, Argonne, Ill.), July 28.

Taipale, C., 1995, unpublished 1994 air monitoring data summaries, transmittal from Taipale (Clark County Health District, Las Vegas, Nev.) to M. Monarch (Argonne National Laboratory, Argonne, IIl.), July 18.

U.S. Department of Energy, 1996, Programmatic Environmental Impact Statement for Stockpile Stewardship and Management, DOE/EIS-0236, Office of Reconfiguration, Washington, D.C.

U.S. Environmental Protection Agency, 1974, "Levels of Environmental Noise in the U.S. and Typical Exposure Patterns of Individuals," Appendix B in Information on Levels of Environmental Noise Requisite to Protect Public Health and Welfare with an Adequate Margin of Safety, 550/9-74-004. Office of Noise Abatement and Control, Washington, D.C.

U.S. Environmental Protection Agency, 1985, Compilation of Air Pollutant Emission Factors, Volume 2 - Mobile Sources (4th Edition), PB87-205266, Ann Arbor, Mich.

U.S. Environmental Protection Agency, 1989, Air/Superfund National Technical Guidance Study Series, Volume III - Estimation of Air Emissions from Cleanup Activities at Superfund Sites, EPA-450/2-89-003, Interim Final, Office of Air Quality Planning and Standards, Research Triangle Park, N.C., Jan.

U.S. Environmental Protection Agency, 1992a, User's Guide for the Industrial Source Complex (ISC2) Dispersion Models, Volume I - User Instructions, EPA-450/4-92-008a, Office of Air Quality Planning and Standards, Research Triangle Park, N.C., March.

U.S. Environmental Protection Agency, 1992b, User's Guide for the Industrial Source Complex (ISC2) Dispersion Models, Volume II - Description of Model Algorithms, EPA-450/4-92-008b, Office of Air Quality Planning and Standards, Research Triangle Park, N.C., March.

U.S. Environmental Protection Agency, 1993, Guidance on Air Quality Models (Revised) Supplement B, EPA-450/2-78-027R, Office of Air Quality Planning Standards, Research Triangle Park, N.C., Jan.

U.S. Environmental Protection Agency, 1995a, Compilation of Air Pollution Emission Factors, AP-42, 5th ed., Office of Air Quality Planning Standards, Research Triangle Park, N.C., Jan. 
U.S. Environmental Protection Agency, 1995b, Surface Meteorological Data Files (CD144 format) and Twice Daily Mixing Height Data (TD9689 format), Support Center for Regulatory Air Models, Bulletin Board System (SCRAM BBS), Office of Air Quality Planning and Standards, Research Triangle Park, N.C. (June date listed on fields electronically accessed).

Wheeler, T., 1995, letter from Wheeler (Sandia National Laboratories, Sandia, N.M.) to J.M. Pfingston (Argonne National Laboratory, Argonne, Ill.), July 28.

White, R., 1995a, transmittal from White (Raytheon Services Nevada, Las Vegas, Nev.) to J.M. Pfingston (Argonne National Laboratory, Argonne, Ill.), Jul 28.

White, R., 1995b, "NIF Site Data for NTS Location," transmittal from White (Raytheon Services Nevada, Las Vegas, Nev.) to C. Burke (Argonne National Laboratory, Argonne, Ill.), June 22. 


\section{SOCIOECONOMICS}

\subsection{INTRODUCTION}

The socioeconomic analysis conducted for the NIF PSA (Appendix I, DOE 1996) involved three principal steps: (1) characterization and projection of existing social, economic, and infrastructure conditions around each candidate site (that is, the reference baseline or affected environment); (2) evaluation of potential changes in socioeconomic conditions that could result from the construction and operation of NIF in the regions addressed (NIF alternative); and (3) evaluation of potential changes in socioeconomic conditions that could result from not constructing NIF (that is, the No Action Alternative). Under the No Action Alternative, NIF would not be constructed at any of the DOE candidate sites, resulting directly in the loss of approximately 100 full-timeequivalent employees at LLNL and 20 each at LANL and SNL.

The following sections describe the methods, models, assumptions, and supporting data sources used in assessing the potential socioeconomic impacts of NIF. The NIF PSA uses some supporting data sources presented in the Stockpile Stewardship and Management Environmental Impact Statement (SSM PEIS) (DOE 1996). This section only addresses those methods, models, assumptions, and supporting data sources that vary from the SSM PEIS. The socioeconomics technical appendix (Appendix D) of the SSM PEIS can be referenced for a description of the general approach and supporting data sources used in conducting the assessment of socioeconomic impacts presented in the NIF PSA.

\subsection{METHODS AND MODELS}

To estimate the potential socioeconomic impacts of the No Action and NIF alternatives, this evaluation examined potential impacts for two larger geographic regions - an economic study area and a region of influence - for each of the five candidate sites. An economic study area was used to estimate the primary economic impact of NIF on earnings and jobs. Each economic study area is coincident with economic areas defined by the U.S. Department of Commerce's Bureau of Economic Analysis (BEA). Each area includes the most important intraregional interactions in broad labor and product markets, trade among and between the most important regional industrial and service sectors, and the most important economic linkages among the communities located in the region. These linkages determine the nature and magnitude of multiplier effects of economic activity at each candidate site. Table 3.1 shows the counties included in the economic study area for each candidate site. 
TABLE 3.1 Economic Study Regions

\begin{tabular}{|c|c|c|c|c|c|}
\hline \multicolumn{2}{|c|}{ Lawrence Livermore National Laboratory ${ }^{\mathrm{a}}$} & \multirow{2}{*}{$\begin{array}{l}\text { Los Alamos National } \\
\text { Laboratory }^{\mathrm{b}}\end{array}$} & \multirow{2}{*}{$\frac{\text { Nevada Test Site }}{\text { Arizona }}$} & \multirow{2}{*}{$\begin{array}{l}\begin{array}{c}\text { North Las Vegas } \\
\text { Facility }\end{array} \\
\text { Arizona }\end{array}$} & \multirow{2}{*}{$\begin{array}{l}\begin{array}{c}\text { Sandia National } \\
\text { Laboratories }\end{array} \\
\text { Arizona }\end{array}$} \\
\hline Merced County & Santa Clara County & & & & \\
\hline Mariposa County & Santa Cruz County & Mora County & Mohave County & Mohave County & Apache County \\
\hline Stanislaus County & Sonoma County & Taos County & Nevada & Nevada & New Mexico \\
\hline Tuolumne County & Lake County & San Miguel County & Nye County & Nye County & Socorro County \\
\hline Contra Costa County & Humboldt County & Los Alamos County & Clark County & Clark County & Valencia County \\
\hline Alameda County & Mendocino County & Santa Fe County & Esmerelda County & Esmerelda County & Catron County \\
\hline Monterey County & Trinity County & Rio Arriba Country & Lincoln County & Lincoln County & Cibola County \\
\hline San Mateo County & San Joaquin County & & Mineral County & Mineral County & McKinley County \\
\hline Marin County & Calaveras County & & Utah & Utah & Sandoval County \\
\hline San Francisco County & Napa County & & Piute County & Piute County & Torrance County \\
\hline \multirow[t]{4}{*}{ San Benito County } & & & Beaver County & Beaver County & Bernalillo County \\
\hline & & & Garfield County & Garfield County & \\
\hline & & & Iron County & Iron County & \\
\hline & & & Washington County & Washington County & \\
\hline
\end{tabular}

a All counties are in Califomia.

b All counties are in New Mexico. 
A second geographical area around each site, referred to as the region of influence (ROI), was used to estimate the potential impacts of the No Action and NIF alternatives on population and housing, public finances and local public service infrastructure, and local transportation. The ROI was defined as the area surrounding each site in which approximately $90 \%$ of the current DOE workforce resides, and counties in which at least $5 \%$ of the DOE workforce lives. The residential distribution information is consistent with data sets presented in Appendix D of the SSM PEIS. Table 3.2 lists the counties and cities included in the ROI for each candidate site.

\subsubsection{Regional Economics}

\subsubsection{Existing and Future Baseline}

The reference baseline was established from regional economic projections to the year 2045 developed by BEA (1996). Current employment levels at four of the candidate sites (excluding NLVF, 1,030 employees in 1995 [White 1995]) are presented in Appendix D of the SSM PEIS. The regional baseline for employment in the affected regional economies is presented in Table 3.3. Adjusted baseline projections account for the increase in regional economic activity resulting from construction and operation of NIF. Effects on regional growth rates are presented under the "Growth Rate" column.

\subsubsection{Potential Project Effects}

\section{General Approach and Methodology}

Final demand multipliers obtained for each region from the U.S. Department of Commerce, BEA Regional Input-Output Modeling System (RIMS II) (BEA 1995) were used in an economic model developed to evaluate socioeconomic impacts of the loss of the ICF program (No Action) and of constructing and operating the NIF. The RIMS II code is based on an accounting framework called an input-output (I-O) table. An I-O table shows, for each industry, industrial distributions of inputs purchased and outputs sold. A typical I-O table in RIMS II derives mainly from two data sources: (1) BEA's national I-O tables, which show the input and output structure (production and consumption of commodities) of nearly 600 U.S. industries; and (2) BEA's four-digit Standard Industrial Classification (SIC) county wage and salary data, which can be used to adjust the national I-O table to show a region's industrial structure and trading patterns (BEA 1992; Repice 1996). Final demand multipliers from RIMS II were used to estimate the impacts of NIF project expenditures by industry on earnings (the sum of wages and salaries, proprietors' income, and other labor income, 
TABLE 3.2 Regions of Influence

\begin{tabular}{|c|c|c|c|c|}
\hline $\begin{array}{l}\text { Lawrence Livermore } \\
\text { National Laboratory }\end{array}$ & $\begin{array}{c}\text { Los Alamos } \\
\text { National Laboratory }\end{array}$ & Nevada Test Site & North Las Vegas Facility & $\begin{array}{c}\text { Sandia National } \\
\text { Laboratories }\end{array}$ \\
\hline Alameda County & Los Alamos County & Clark County & Clark County & Bernalillo County \\
\hline Contra Costa County & Rio Arriba County & Nye County & Nye County & Valencia County \\
\hline San Joaquin County & Santa Fe County & City of Henderson & City of Henderson & Sandoval County \\
\hline City of Livermore & City of Santa Fe & City of Las Vegas & City of Las Vegas & City of Albuquerque \\
\hline City of Pleasanton & City of Espanola & City of North Las Vegas & City of North Las Vegas & \\
\hline \multicolumn{5}{|l|}{ City of Manteca } \\
\hline City of Tracy & & & & \\
\hline
\end{tabular}


TABLE 3.3 Regional Economic Impact Analysis Comparison - Baseline and NIF Alternative Employment Forecasts ${ }^{\mathrm{a}}$

\begin{tabular}{|c|c|c|c|c|c|c|c|c|c|c|c|}
\hline \multirow{2}{*}{$\begin{array}{l}\text { BEA Economic Area } \\
\text { (NIF Site) }\end{array}$} & \multicolumn{10}{|c|}{ Number Employed } & \multirow{2}{*}{$\begin{array}{l}\text { Growth } \\
\text { Rate (\%) }\end{array}$} \\
\hline & 1980 & 1995 & 1996 & 1997 & 1998 & 1999 & 2000 & 2001 & 2002 & 2003 & \\
\hline \multicolumn{12}{|c|}{ San Francisca-Oakland-San Jose, CA (LLNL) } \\
\hline Baseline & $3,752,900$ & $4,888,941$ & $4,976,984$ & $5,066,613$ & $5,157,856$ & $5,250,741$ & $5,345,300$ & $5,428,001$ & $5,511,982$ & $5,597,262$ & 1.706 \\
\hline W/NIF & & $4,888,941$ & $4,977,404$ & $5,067,792$ & $5,160,716$ & $5,253,422$ & $5,347,098$ & $5,429,205$ & $5,512,416$ & $5,598,156$ & 1.708 \\
\hline Growth Rate Increase & & & & & & & & & & & 0.002 \\
\hline \multicolumn{12}{|l|}{ Santa Fe, NM (LANL) } \\
\hline Baseline & 78,500 & 132,988 & 136,464 & 140,031 & 143,691 & 147,446 & 151,300 & 154,225 & 157,206 & 160,245 & 2.358 \\
\hline WNIF & & 132,988 & 136,561 & 140,385 & 144,810 & 148,295 & 151,627 & 154,436 & 157,267 & 160,840 & 2.405 \\
\hline Growth Rate Increase & & & & & & & & & & & 0.047 \\
\hline \multicolumn{12}{|c|}{ Las Vegas, NV-AZ-UT (NTS and NLVF) } \\
\hline Bascline & 320,400 & 653,026 & 676,440 & 700,694 & 725,818 & 751,842 & 778,800 & 799,185 & 820,103 & 841,568 & 3.221 \\
\hline WNIF & & 653,026 & 676,594 & 701,174 & 727,438 & 753,059 & 779,218 & 799,448 & 820,182 & 842,184 & 3.231 \\
\hline Growth Rate Increase & & & & & & & & & & & 0.009 \\
\hline \multicolumn{12}{|l|}{ Albuquerque, NM-AZ (SNL) } \\
\hline Baseline & 290,100 & 450,282 & 460,565 & 471,083 & 481,841 & 492,845 & 504,100 & 512,963 & 521,981 & 531,159 & 2.086 \\
\hline W/NIF & & 450,282 & 460,720 & 471,594 & 483,493 & 494,149 & 504,619 & 513,282 & 522,066 & 531,829 & 2.102 \\
\hline Growth Rate Increase & & & & & & & & & & & 0.016 \\
\hline
\end{tabular}

2 Forecasts are based on BEA (1996). 
less employer contributions to private pension and welfare funds), and employment (number of jobs).

NIF cost data were obtained from the NIF Conceptual Design Report (LLNL 1994) and were translated from work, breakdown structure (WBS) categories to RMMS II industries. These cost data were then converted to final demand estimates and were applied to the appropriate RIMS II multipliers to project regional economic impacts. Final demand estimates reflect expenditures in the regional economy and were calculated by estimating regional purchase coefficients on the basis of historical procurement data (Paisner 1995). Figure 3.1 shows the major industrial sectors impacted by NIF construction.

\section{Comparison of Regional Economic and Demographic Impacts}

Figure 3.2 illustrates the relative regional economic impact on projected baseline employment levels for each of the affected regional economies. The percentage increase along the vertical axis reflects the increase of the projected NIF impact over the reference baseline presented in Table 3.3. Although the graph ends at year 2003, the level of impact in 2003 is expected to remain relatively constant for the projected operational period.

Figures 3.3 through 3.6 show the breakdown of economic effects resulting from regional NIF spending and investment at each site. Figures 3.7 through 3.10 show direct (at the NIF site), indirect (resulting from the multiplier effect), and total (direct plus indirect) job creation in the regional economies presented in Table 3.1, as well as in-migration for the affected regions of influence. Assumptions used to calculate in-migration occurring at each site with NIF are shown in Table 3.4. A summary of projected employment impacts in each regional economy for each construction year and for the first year of operation is provided in Table 3.5. The table also includes the residual U.S. employment impact resulting from extra-regional leakage at each candidate site.

\section{Impacts on the U.S. Economy}

The approach used to model the impacts of NIF spending on the U.S. economy is similar to that described for the regional economic impact analysis, except that RIMS II multipliers for the U.S. economy were used in place of the regional multipliers. Also, it was assumed that all final demand changes resulting from NIF procurement would occur within the U.S. economy (i.e., no leakage to foreign markets for importing goods or services). The results of this analysis are presented in Table 3.5. The values for the United States indicate the total employment effect of constructing and operating NIF. 


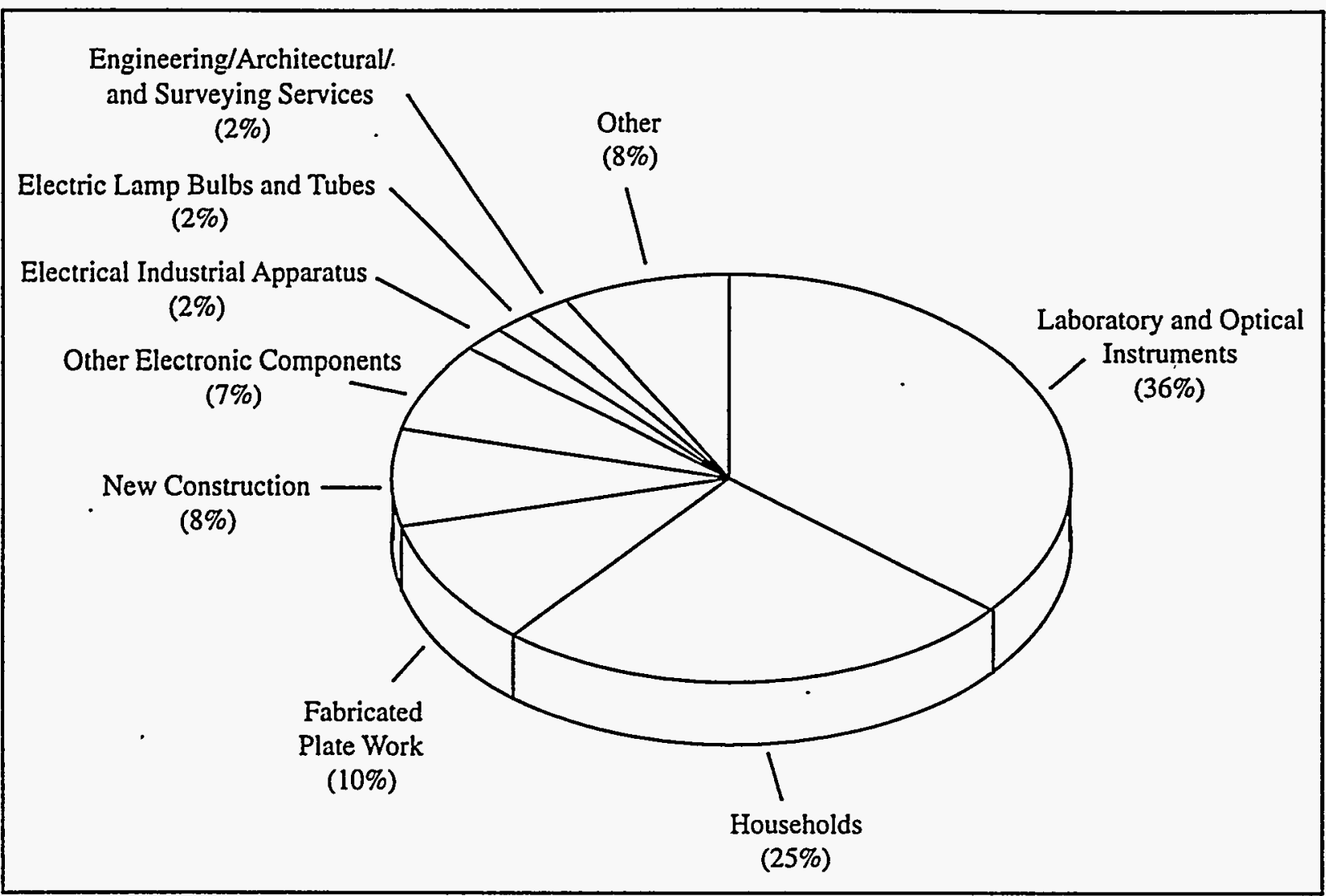

FIGURE 3.1 Industry Share of Total NIF Construction Cost

\subsubsection{Population In-Migration}

Changes in regional and local economic activity affect regional and local demographics. To project potential population changes resulting from construction and operation of NIF, population in-migration scenarios were developed for each candidate site. Estimated direct and indirect jobs created as a result of constructing and operating NIF are the basis for the assessment of population in-migration impacts. Some of these jobs would be supplied by local labor markets; however, others would be supplied by workers migrating into the region as a result of the marginal increase in economic opportunity from constructing and operating NIF. Additional population would have the potential to burden public infrastructure and create additional demand in local housing markets.

Different assumptions related to the proportion of direct and indirect jobs supplied by the local labor force were applied to each job (direct or indirect). These assumptions were based on a comparison of the industrial composition of each regional economy (that is, presence of NIF-related industries) and the size of the unemployed labor force for each economic study area. A relative ranking scheme was used for those industrial sectors substantially affected by local NIF 


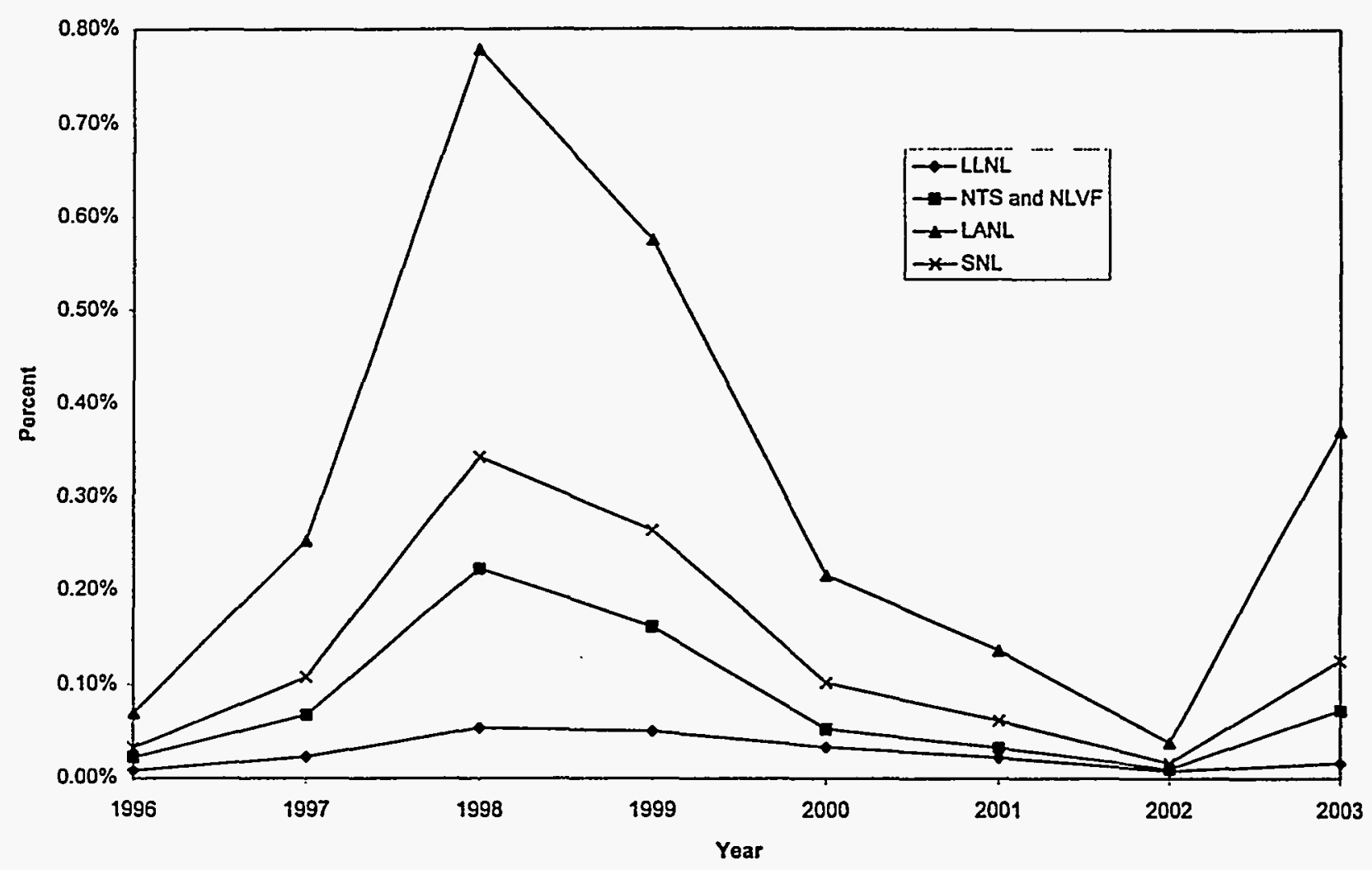

FIGURE 3.2 Relative Regional Economic Impact Comparison

procurement. A percentage factor was applied to each job to calculate those jobs supplied by the local labor force. The highest ranking economic sector was assigned the lowest migration rate; while the lowest sector was assigned the highest migration rate.

The residual, those jobs created in economic sectors (industries) not substantially affected, was assigned a migration rate relative to the unemployed labor force in each of the economic study areas. These labor markets were ranked according to size, and an assumed percentage of each job supplied by the local labor market was applied on the basis of the ranking scheme. The lowest assumed proportion was applied to the largest labor pool; while the highest assumed proportion was applied to the smallest labor pool.

The total population in-migration in any given year was calculated as the sum of direct and indirect in-migration (based on the previously described methodology) multiplied by an average household size (based on an empirical study of migration from region to region). In-migration rate assumptions for each candidate site are listed in Table 3.4. The approach provides a reasonable relative comparison of impacts related to constructing and operating NIF at each candidate site. 


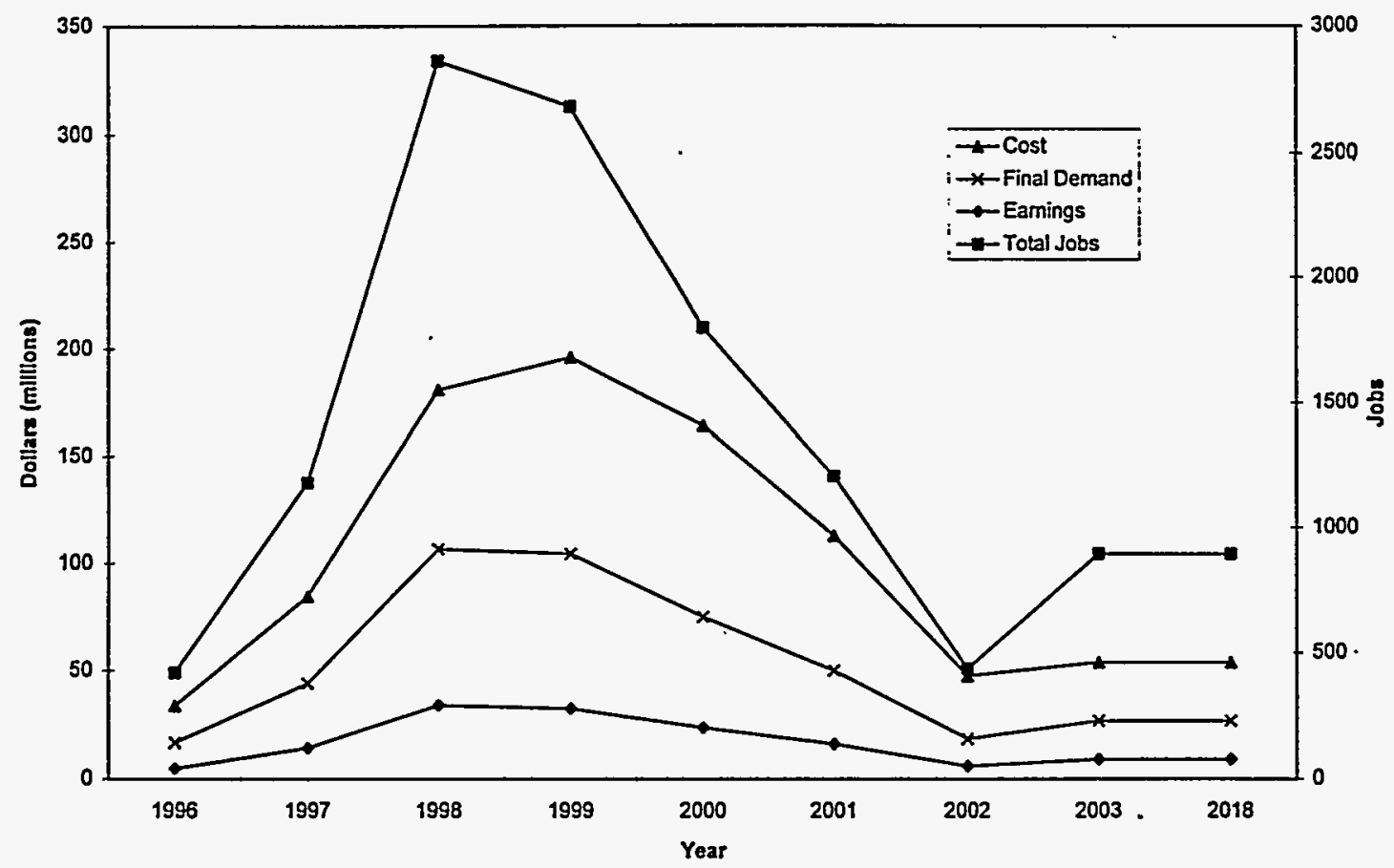

FIGURE 3.3 Impacts of NIF Spending on the LLNL Regional Economy

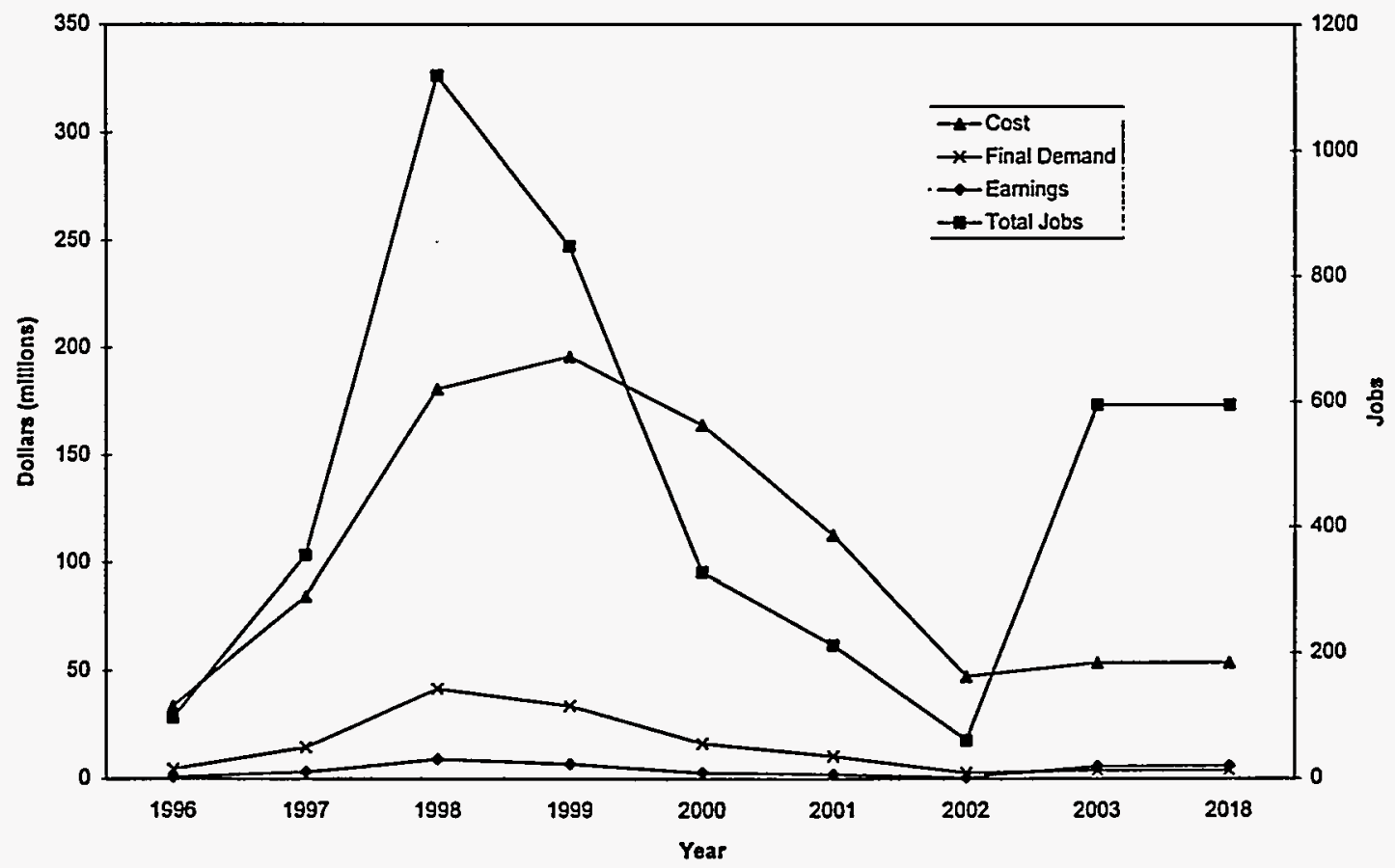

FIGURE 3.4 Impacts of NIF Spending on the LANL Regional Economy 


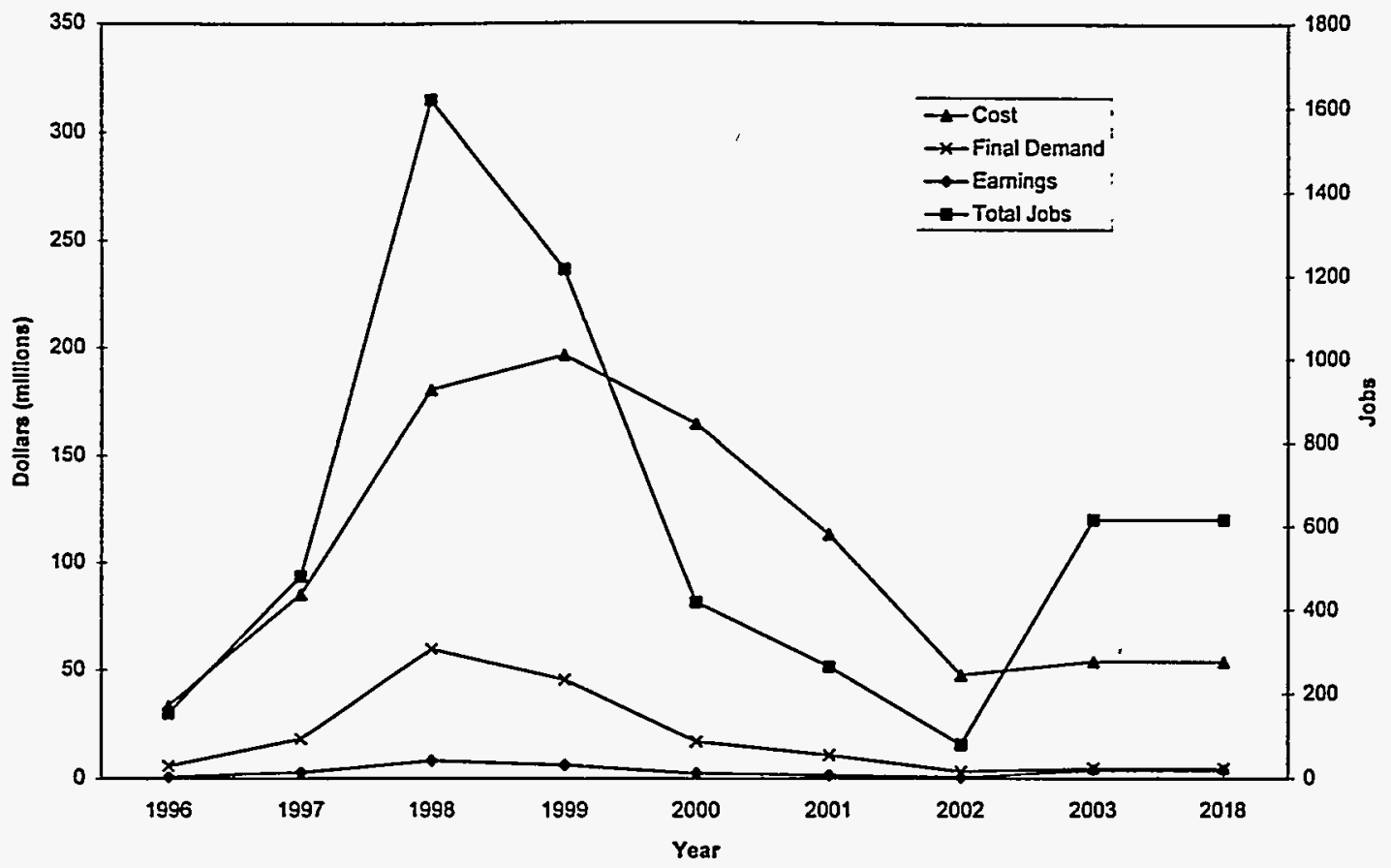

FIGURE 3.5 Impacts of NIF Spending on the NTS/NLVF Regional Economy

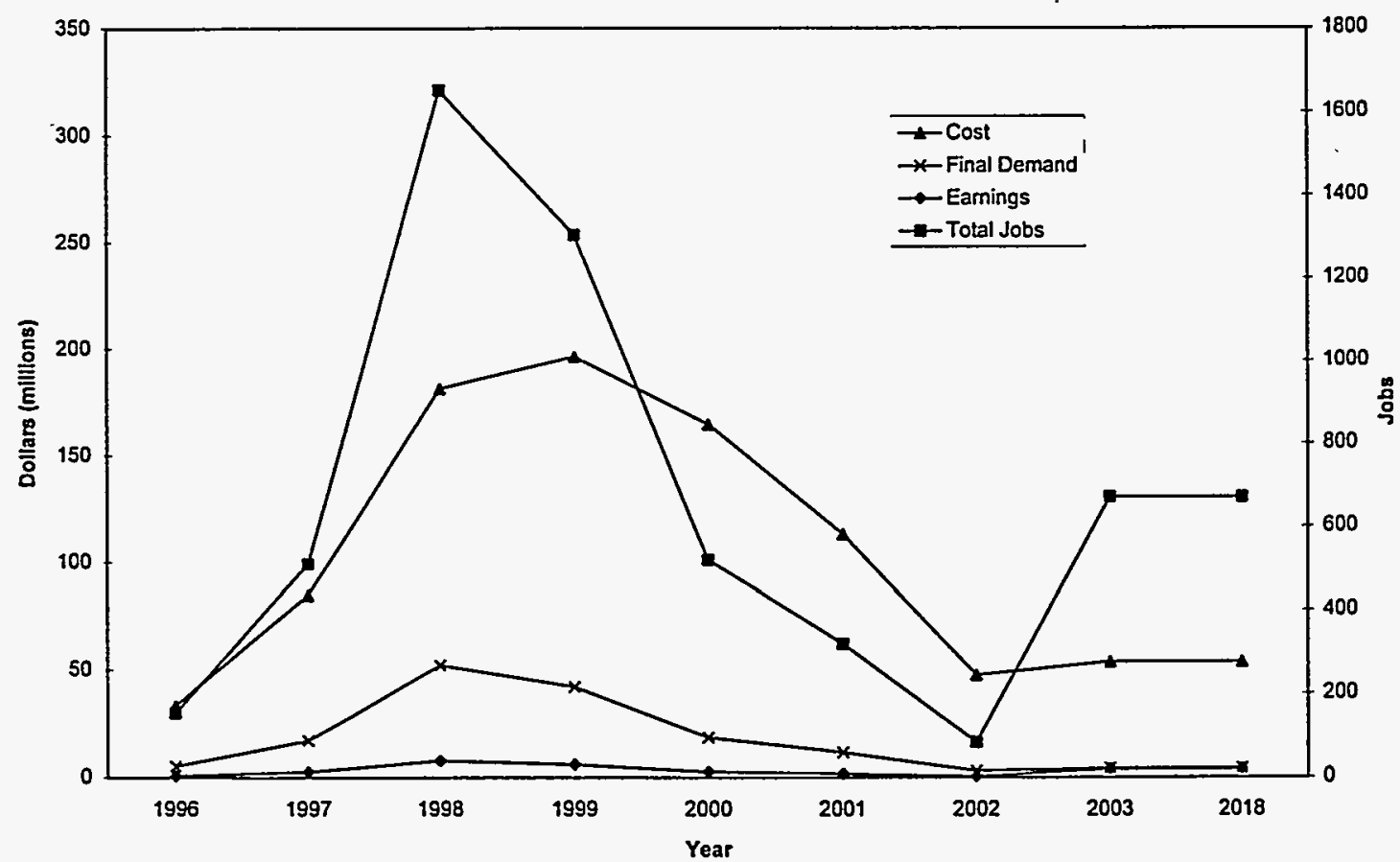

FIGURE 3.6 Impacts of NIF Spending on the SNL Regional Economy 


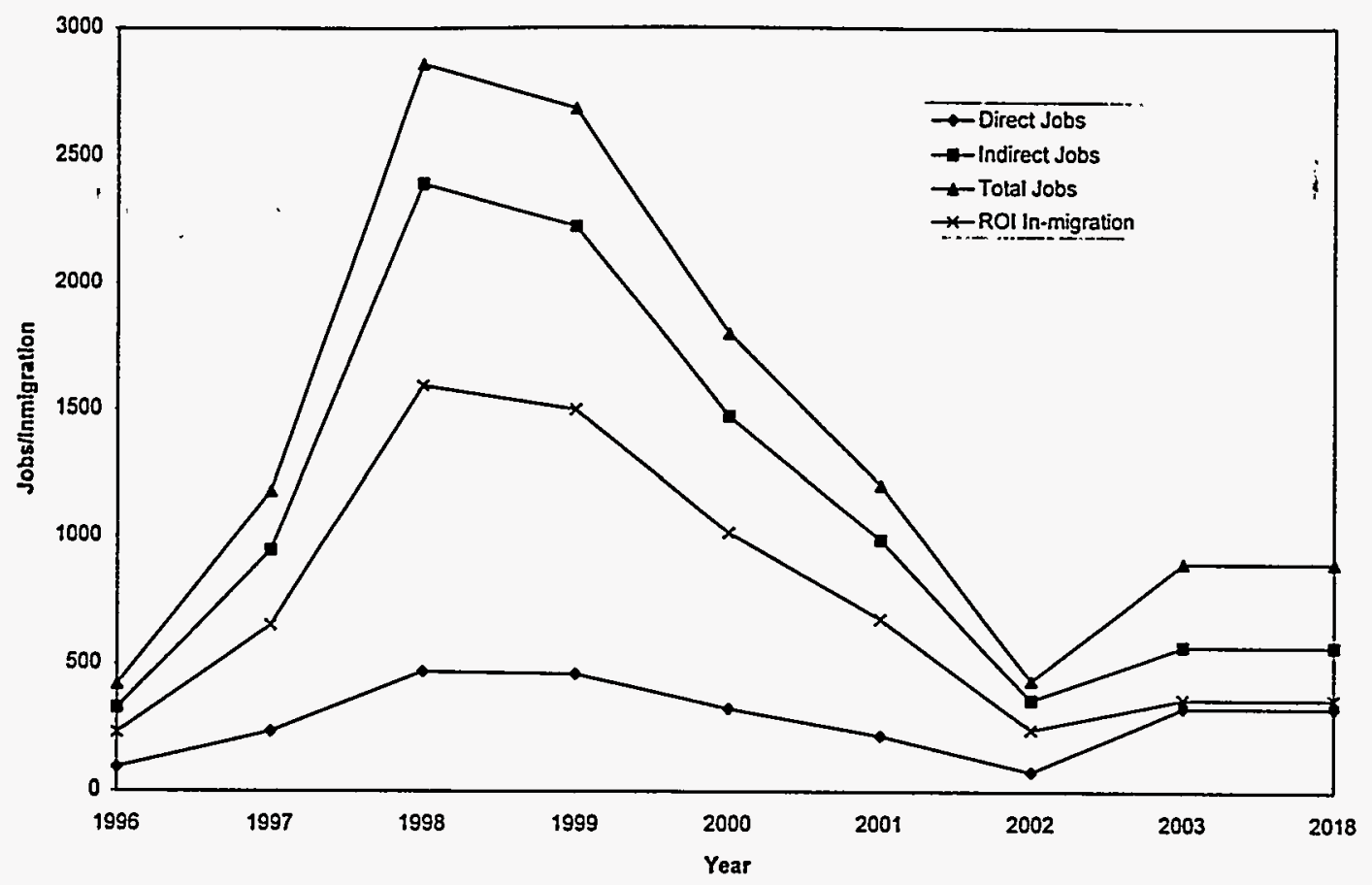

FIGURE 3.7 Economic and Demographic Impacts at LLNL

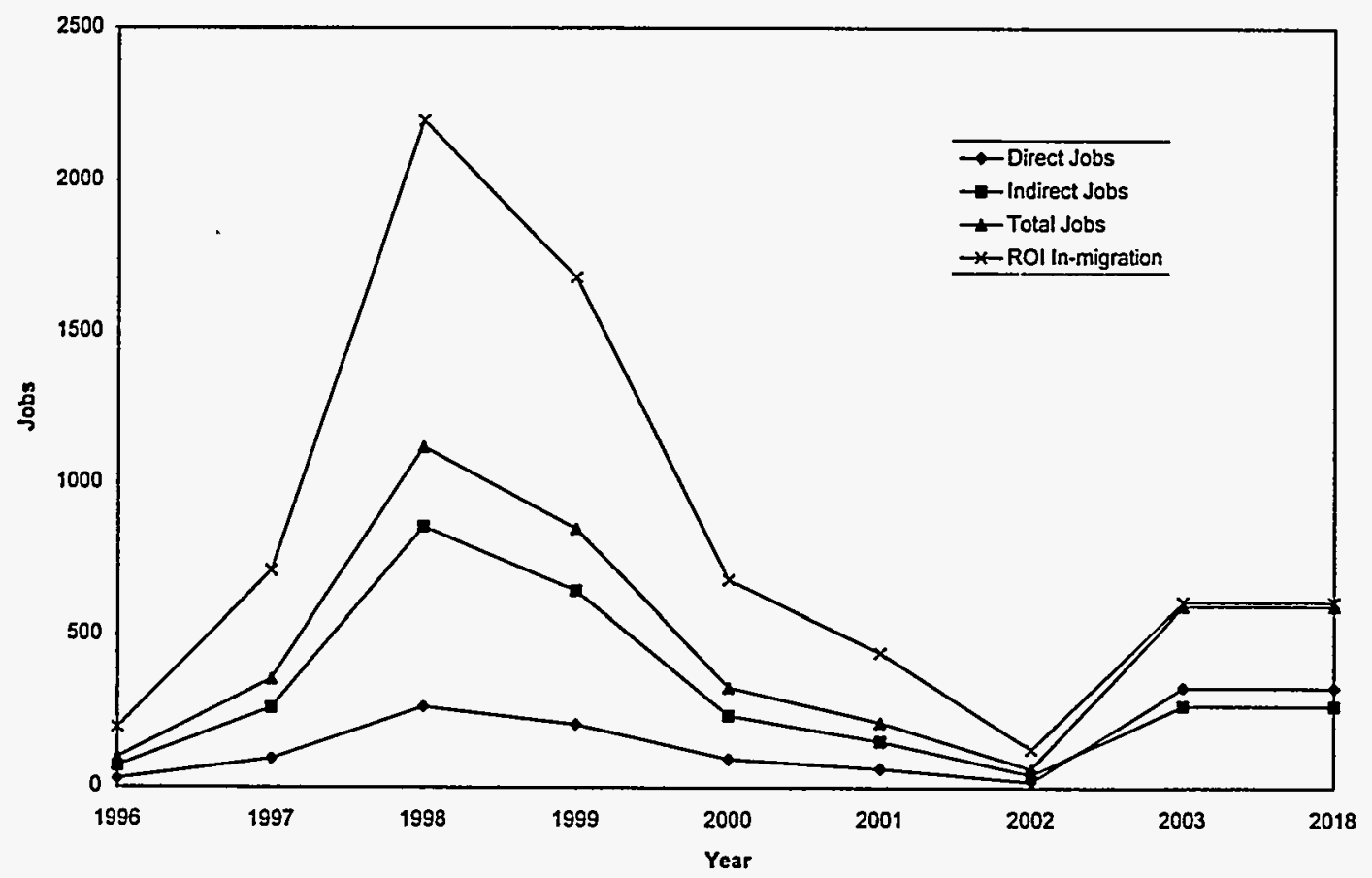

FIGURE 3.8 Economic and Demographic Impacts at LANL 


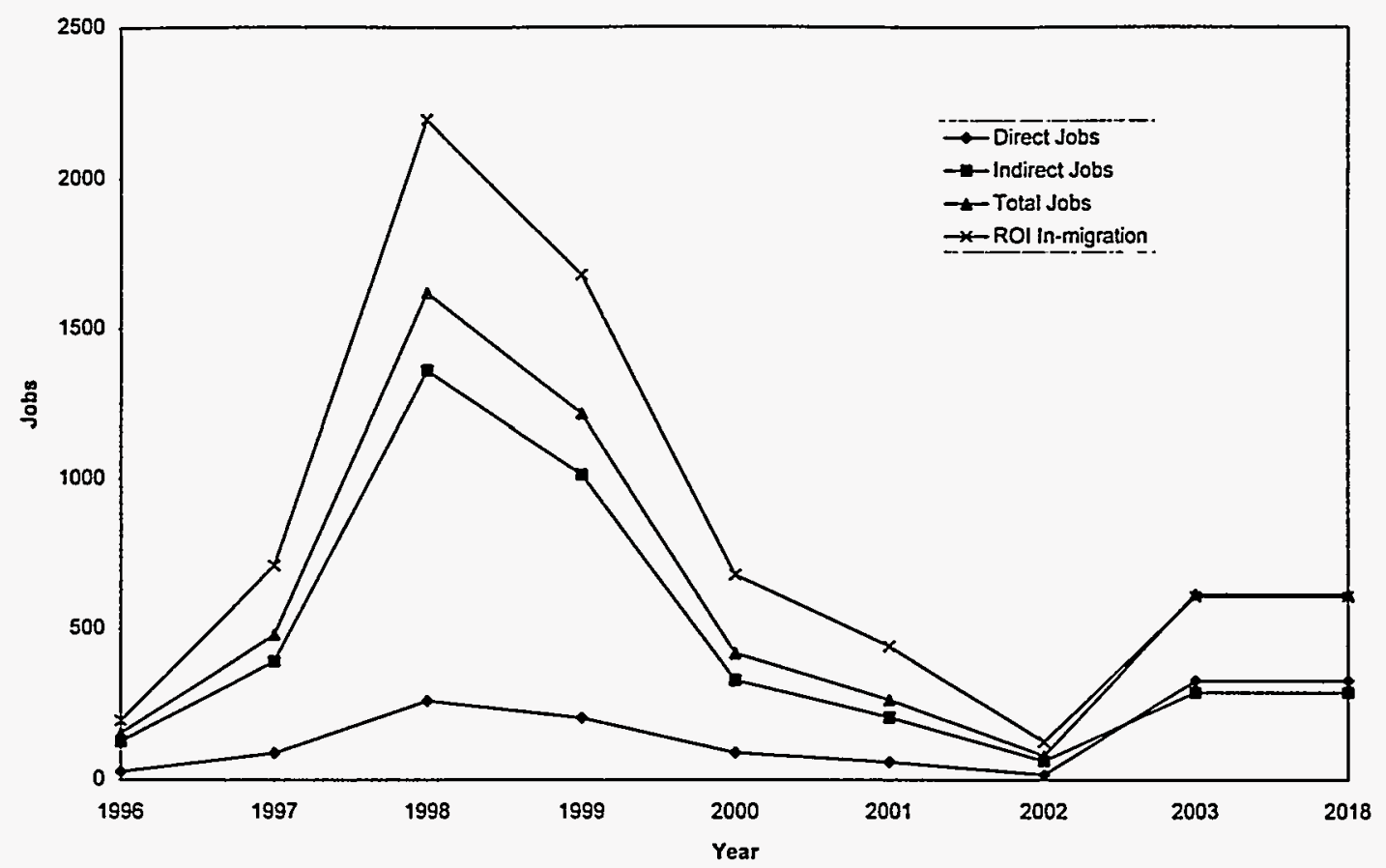

FIGURE 3.9 Economic and Demographic Impacts at NTS/NLVF

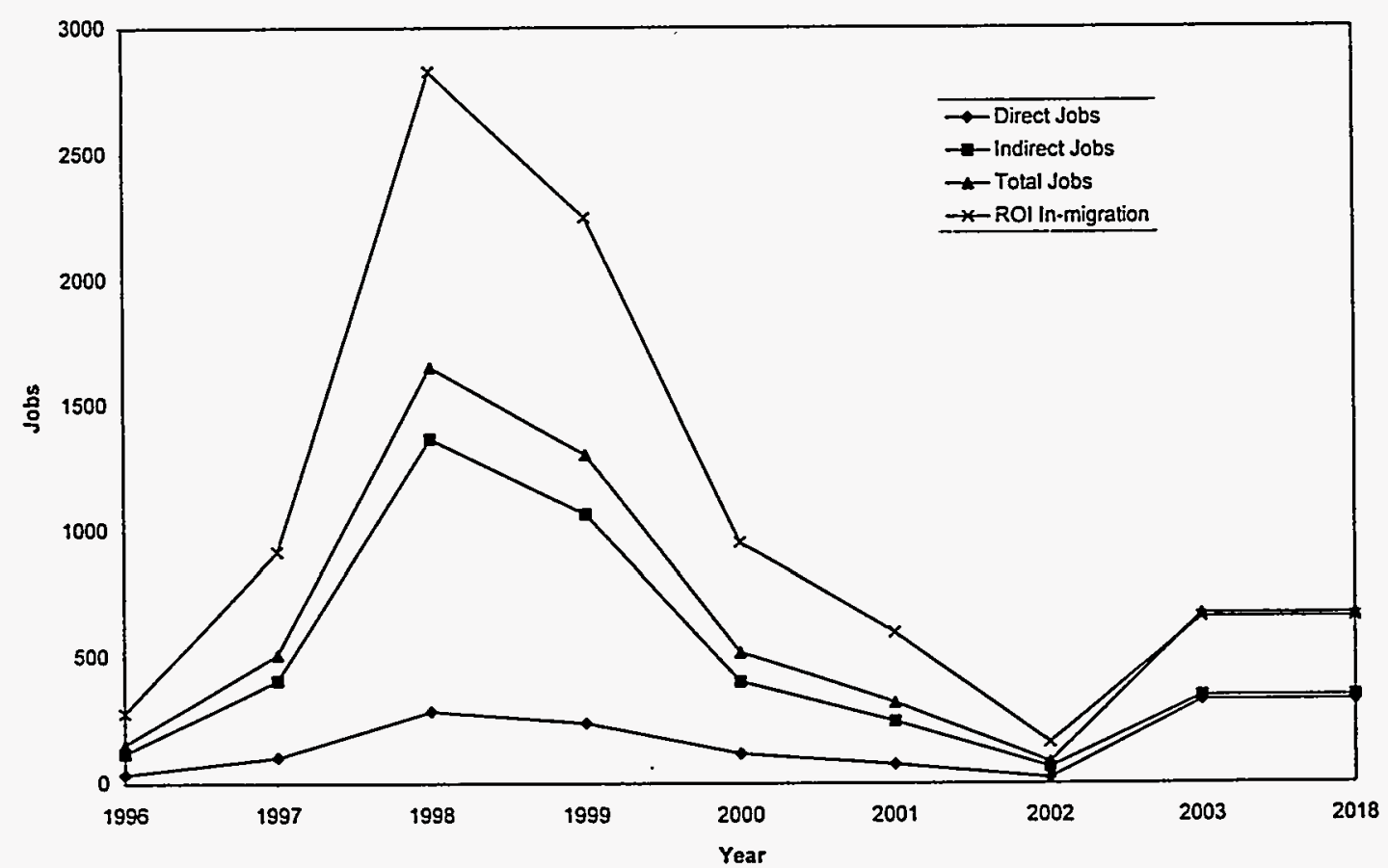

FIGURE 3.10 Economic and Demographic Impacts at SNL 
TABLE 3.4 Site-Specific In-Migration Rate Assumptions

\begin{tabular}{|c|c|c|c|c|c|c|c|c|}
\hline \multirow[b]{2}{*}{ Regional Labor Market } & \multicolumn{8}{|c|}{ In-Migration Rate, ${ }^{\mathrm{a}}$ by Year } \\
\hline & 1996 & 1997 & 1998 & 1999 & 2000 & 2001 & 2002 & 2003 \\
\hline \multicolumn{9}{|l|}{ LLNL } \\
\hline Direct In-Migration Rate & 0.096 & 0.086 & 0.058 & 0.073 & 0.092 & 0.090 & 0.075 & 0 \\
\hline Indirect In-Migration Rate & 0.250 & 0.250 & 0.250 & 0.250 & 0.250 & 0.250 & 0.250 & 0.250 \\
\hline \multicolumn{9}{|l|}{ LANL } \\
\hline Direct In-Migration Rate & 0.575 & 0.478 & 0.276 & 0.333 & 0.656 & 0.697 & 0.687 & 0.250 \\
\hline Indirect In-Migration Rate & 0.945 & 0.952 & 0.976 & 0.973 & 0.937 & 0.927 & 0.928 & 0.939 \\
\hline \multicolumn{9}{|l|}{ NTS and NLVF } \\
\hline Direct In-Migration Rate & 0.550 & 0.474 & 0.305 & 0.348 & 0.660 & 0.715 & 0.714 & 0.250 \\
\hline Indirect In-Migration Rate & 0.724 & 0.623 & 0.584 & 0.596 & 0.664 & 0.739 & 0.861 & 0.573 \\
\hline \multicolumn{9}{|l|}{ SNL } \\
\hline Direct In-Migration Rate & 0.565 & 0.482 & 0.288 & 0.354 & 0.605 & 0.642 & 0.655 & 0.250 \\
\hline Indirect In-Migration Rate & 0.707 & 0.723 & 0.716 & 0.713 & 0.713 & 0.720 & 0.731 & 0.717 \\
\hline
\end{tabular}

a Percentage of in-migrants from outside of the regional economic study area.

\subsubsection{Housing}

Population and employment changes associated with NIF could potentially affect housing supply in the project area. Projected housing needs were developed from several data sets. The first data set used for this study was population projections provided by the BEA (1995). These data were used to project baseline population for the life of NIF.

The second data set used for this analysis was the 1990 Census of Population and Housing (U.S. Bureau of the Census 1991). These data were used to establish the total number of housing units (owner and renter) for each ROI in 1990. An average annual growth rate for housing units was established for the years between 1980 and 1990. This rate was applied to the project construction and operation years to establish the estimated number of housing units in an ROI for those years. By holding the ratio of owner to renter units constant, the approximate number of vacant owner and renter units was projected for the project construction and operation years. A household size-topopulation ratio was then applied to the estimated future population trends to obtain the number of housing units needed to accommodate the projected population for a future reference baseline. 
TABLE 3.5 Employment Impact Summary - U.S. and Regional Economies

\begin{tabular}{|c|c|c|c|c|c|c|c|c|c|}
\hline \multirow[b]{2}{*}{ Component } & \multicolumn{7}{|c|}{ Construction/Assembly Phase and Other Project Activities } & \multirow{2}{*}{$\begin{array}{c}\begin{array}{c}\text { Average } \\
\text { Annual }\end{array} \\
1996 \text { to } 2002\end{array}$} & \multirow{2}{*}{$\begin{array}{l}\text { Operations } \\
2003 \text { to } 2018\end{array}$} \\
\hline & 1996 & 1997 & 1998 & 1999 & 2000 & 2001 & 2002 & & \\
\hline \multicolumn{10}{|l|}{ LLNL Region } \\
\hline Direct & 93 & 234 & 467 & 458 & 323 & 218 & 76 & 267 & 327 \\
\hline Indirect & 327 & 945 & 2,393 & 2,223 & 1,474 & 986 & 358 & 1,244 & 568 \\
\hline Total & 420 & 1,179 & 2,860 & 2,681 & 1,798 & 1,204 & 434 & 1,511 & 895 \\
\hline \multicolumn{10}{|l|}{ U.S. Residual } \\
\hline Direct & 78 & 23 & 30 & 39 & 34 & 22 & 6 & 33 & 0 \\
\hline Indirect & 526 & 1,359 & 3,042 & 3,446 & 2,974 & 2,034 & 900 & 2,040 & 650 \\
\hline Total & 604 & 1,382 & 3,072 & 3,484 & 3,007 & 2,056 & 907 & 2,073 & 650 \\
\hline \multicolumn{10}{|l|}{ LANL Region } \\
\hline Direct & 28 & 93 & 264 & 206 & 92 & 61 & 19 & 109 & 327 \\
\hline Indirect & 69 & 261 & 855 & 643 & 235 & 150 & 42 & 322 & 268 \\
\hline Total & 97 & 355 & 1,119 & 848 & 327 & 212 & 61 & 431 & 595 \\
\hline \multicolumn{10}{|l|}{ U.S. Residual } \\
\hline Direct & 143 & 164 & 234 & 291 & 265 & 179 & 64 & 191 & 0 \\
\hline Indirect & 784 & 2,042 & 4,580 & 5,026 & 4,213 & 2,870 & 1,216 & 2,962 & 950 \\
\hline Total & 927 & 2,206 & 4,814 & 5,317 & 4,478 & 3,048 & 1,280 & 3,153 & 950 \\
\hline
\end{tabular}


TABLE 3.5 (Cont.)

\begin{tabular}{|c|c|c|c|c|c|c|c|c|c|}
\hline \multirow[b]{2}{*}{ Component } & \multicolumn{7}{|c|}{ Construction/Assembly Phase and Other Project Activities } & \multirow{2}{*}{$\begin{array}{c}\begin{array}{c}\text { Average } \\
\text { Annual }\end{array} \\
1996 \text { to } 2002\end{array}$} & \multirow{2}{*}{$\begin{array}{l}\text { Operations } \\
2003 \text { to } 2018\end{array}$} \\
\hline & 1996 & 1997 & 1998 & 1999 & 2000 & 2001 & 2002 & & \\
\hline \multicolumn{10}{|l|}{ SNL Region } \\
\hline Direct & 35 & 103 & 284 & 238 & 117 & 75 & 21 & 125 & 327 \\
\hline Indirect & 119 & 407 & 1,368 & 1,066 & 402 & 245 & 63 & 524 & 344 \\
\hline Total & 154 & 511 & 1,652 & 1,304 & 519 & 319 & 84 & 649 & 671 \\
\hline \multicolumn{10}{|l|}{ U.S. Residual } \\
\hline Direct & 136 & 154 & 214 & 258 & 240 & 165 & 61 & 176 & 0 \\
\hline Indirect & 733 & 1,896 & 4,067 & 4,603 & 4,046 & 2,775 & 1,195 & 2,759 & 874 \\
\hline Total & 869 & 2,050 & 4,281 & 4,861 & 4,286 & 2,940 & 1,257 & 2,935 & 874 \\
\hline \multicolumn{10}{|c|}{ NTS/NLVF Region } \\
\hline Direct & 27 & 88 & 260 & 203 & 89 & 58 & 17 & 106 & 327 \\
\hline Indirect & 127 & 392 & 1,360 & 1,013 & 329 & 206 & 62 & 498 & 289 \\
\hline Total & 154 & 480 & 1,620 & 1,216 & 418 & 264 & 79 & 604 & 616 \\
\hline \multicolumn{10}{|l|}{ U.S. Residual } \\
\hline Direct & 144 & 169 & 238 & 293 & 268 & 182 & 65 & 194 & 0 \\
\hline Indirect & 725 & 1,912 & 4,075 & 4,656 & 4,119 & 2,814 & 1,196 & 2,785 & 929 \\
\hline Total & 870 & 2,081 & 4,313 & 4,949 & 4,387 & 2,996 & 1,261 & 2,980 & $929^{\circ}$ \\
\hline \multicolumn{10}{|c|}{ U.S. Economy (Total Effect) } \\
\hline Direct & 171 & 257 & 498 & 496 & 357 & 240 & 83 & 300 & 327 \\
\hline Indirect & 853 & 2,303 & 5,435 & 5,669 & 4,448 & 3,020 & 1,258 & 3,284 & 1,218 \\
\hline Total & 1,024 & 2,561 & 5,933 & 6,165 & 4,805 & 3,260 & 1,341 & 3,584 & 1,545 \\
\hline
\end{tabular}


Housing needs for the NIF construction and operation workforce, which were estimated on the basis of data in the economic and in-migration section of this study, were then compared with the number of vacant units projected to be present in each ROI. This comparison was made for the largest in-migrating workforce and their families and was used as a conservative scenario to assess potential impacts on housing supply in a particular ROI.

Housing need projections for each of the five candidate sites were developed in the same manner as the estimates for the reference baseline. Employment projections were used to estimate the size of the in-migrating workforce required for NIF construction and operation. Housing needs for the NIF construction and operation workforce were then estimated by adding the in-migrating workforce to the future reference baseline.

\subsubsection{Public Finance}

Finances of the ROI local jurisdictions were evaluated on the basis of historic revenue and expenditure levels. These historic fiscal characteristics were obtained from comprehensive annual financial reports supplied by each jurisdiction. The analysis focused on each jurisdiction's governmental funds, including general fund, special revenue funds, and, as applicable, capital projects, debt service, and expendable trust funds. The analysis of local jurisdictions' public finances focused upon fiscal balances (revenue and expenditure) because no reasonable assumptions could be made for some projected fund balances (such as capital expenditures) so far into the future. Estimated changes in population as a result of the proposed actions were used to project changes in total revenue and expenditures for each jurisdiction.

\subsubsection{Public Services}

Potential effects on the public services provided by the local jurisdictions caused by changes in demand associated with the proposed action were determined for each region. The levels of general public service were determined by the ratios of employees (for example, sworn officers, professional firefighters) to service populations. Existing level-of-services ratios were determined for each jurisdiction individually. Those ratios were adjusted to account for economies and diseconomies of scale. The adjusted ratios were then used to estimate jurisdiction-specific future requirements for services on the basis of the projected population growth in the ROI.

\subsubsection{Local Transportation}

Population and employment changes associated with NIF would have the potential to affect transportation conditions in the project area. Traffic impacts were modeled with a proprietary 
transportation model developed in accordance with the Highway Capacity Manual's methodology for freeways, multi-lane roads, and two-lane roads (Transportation Research Board 1985). Average annual daily traffic (AADT) volumes were projected for 1995 and the impact year for no-action population projections, which represent the population expected to live in an ROI if no action was taken (no projects were constructed). The AADT data in the impact years (the year with the highest number of construction workers or the year with the highest number of operation workers) for each candidate site were projected on the basis of the no-action population projections. This AADT projection was used to develop the future baseline traffic conditions.

The future baseline year is the year that the maximum impacts are expected; however, traffic conditions reflect future traffic without project construction and operation workers. Moreover, the future baseline year reflects future traffic conditions in an ROI without NIF.

The AADT information for impacts beyond the future baseline was calculated on the basis of the direct employment and direct in-migrating population associated with each alternative. Only roads in the vicinity of a site on which at least $5 \%$ of new workers travel were modeled for 1995, the future baseline year, and the future impact year. The assumption was made that the additional workers would use the same roads as now used by the current workforce.

Service flow also was calculated for the road segments for 1995, the future baseline year, and the future impact year. Service flow is the maximum hourly rate at which vehicles can reasonably be expected to cross a point of a lane during a given time period under current roadway and traffic conditions. Service flow rates are discrete values, while level of service represents a range of conditions. Various adjustment factors were assumed or calculated. Capacity of the road segments was calculated from the number of lanes and capacity per lane. The service flow equation was solved for the volume-to-capacity ratio. This ratio was used to find 1995, future baseline, and future impact levels of service.

Level of service is a qualitative measure describing operational conditions within a traffic stream. A level of service definition generally describes these conditions in terms of such factors as speed and travel time, freedom to maneuver, traffic interruptions, comfort and convenience, and safety. The level of service scale ranges form $A$ to $F$, with each level defined by a range of volumeto-capacity ratios. Levels of service $\mathrm{A}, \mathrm{B}$, and $\mathrm{C}$ are considered good operating conditions where minor or tolerable delays are experienced by motorists. Level of service $D$ represents below-average conditions. Level of service E corresponds to the maximum capacity of the roadway, a jammed condition. The level of service designations are defined in Table 3.6. These levels are based primarily on a report by the Transportation Research Board (1985). 
TABLE 3.6 Roadway Level-of-Service Letter Designations and Definitions

\begin{tabular}{|c|c|c|}
\hline $\begin{array}{l}\text { Letter } \\
\text { Designation }\end{array}$ & $\begin{array}{l}\text { Operating } \\
\text { Conditions }\end{array}$ & Definition \\
\hline A & Good & $\begin{array}{l}\text { A condition of free flow, accompanied by low volumes and } \\
\text { high speeds. }\end{array}$ \\
\hline B & Good & $\begin{array}{l}\text { This level occurs in a zone of stable flow, with operating } \\
\text { speeds beginning to be restricted somewhat by traffic } \\
\text { conditions. }\end{array}$ \\
\hline $\mathrm{C}$ & Good & $\begin{array}{l}\text { This level is still in a zone of stable flow, but speeds and } \\
\text { maneuverability are more closely controlled by the higher } \\
\text { volumes. }\end{array}$ \\
\hline $\mathrm{D}$ & Below Average & $\begin{array}{l}\text { This level of service approaches unstable flow, with tolerable } \\
\text { operating speeds being maintained, though considerably } \\
\text { affected by changes in operating conditions. }\end{array}$ \\
\hline $\mathrm{E}$ & Maximum Capacity & $\begin{array}{l}\text { This level cannot be described by speed alone, but represents } \\
\text { operations at lower operating speeds, typically, but not always, } \\
\text { in the neighborhood of } 30 \mathrm{mph} \text {, with volumes at or near the } \\
\text { capacity of the highway. }\end{array}$ \\
\hline $\mathrm{F}$ & Traffic Jam & $\begin{array}{l}\text { This level describes a forced-flow operation at low speeds, } \\
\text { where volumes are below capacity }\end{array}$ \\
\hline
\end{tabular}

Source: Transportation Research Board (1985).

\subsubsection{Environmental Justice}

\subsubsection{Introduction}

On February 11, 1994, President Clinton issued Executive Order 12898, Federal Actions to Address Environmental Justice in Minority Populations and Low-Income Populations (59 FR 7629). This Executive Order, with the accompanying cover memo, calls on Federal agencies to incorporate environmental justice as part of their missions, including decisions made in compliance with the National Environmental Policy Act (NEPA) of 1969 (42 USC 4321 et seq.). Specifically, the President's cover memo to the Environmental Justice Executive Order mentions NEPA in the following context:

Each Federal agency shall analyze the environmental effects, including human health, economic, and social effects, of Federal actions, including effects on minority communities and low-income communities, when such analysis is required by the National Environmental Policy Act of 1969 (NEPA), 42 U.S.C. 
Section 4321 et seq. Mitigation measures outlined or analyzed in an environmental assessment, environmental impact statement, or record of decision, whenever feasible, should address significant and adverse environmental effects of proposed Federal actions on minority communities and low-income communities.

In addition, Executive Order 12898 establishes an Interagency Working Group, one function of which is to provide guidance on the implementation of the Executive Order. At the time of this writing, no final guidance has been issued by the Working Group. However, the Working Group has issued draft working definitions, which are the basis for much of the approach employed in this analysis.

The analysis presented here is a partial response to the requirements of Executive Order 12898 and is intended to assess the potential for high and adverse environmental and/or human health impacts associated with the NIF project to disproportionately affect minority or low-income populations.

In addition to the analyses presented here, Executive Order 12898 and its cover memo also require that: "Each Federal agency shall provide opportunities for community input in the NEPA process, including identifying potential effects and mitigation measures in consultation with affected communities and improving the accessibility of meetings, crucial documents, and notices." Section 1.8 of the SSM PEIS (DOE 1996) describes the scoping process employed for the PEIS, including the PSA. The scoping process and the comments recorded during it are also described in the Draft Implementation Plan (IP) for the SSM PEIS. Scoping comments on environmental justice stipulated that "thorough investigations of the following should be conducted: proximity of proposed facilities to culturally important areas such as ancient burial grounds; transportation, storage, and disposal of nuclear waste on Native American lands; and cleanup of testing sites" (Draft IP, p. E-5, issue code 12.1). In addition, one comment asked that DOE involve Native Americans in the NEPA process and honor agreements with Native Americans. A number of representatives of American Indian tribes participated in the scoping process. Additional information has also been provided, as appropriate, in response to public comments on the Draft SSM PEIS. The public response process also provided the opportunity for "consultation with affected communities" in "identifying potential effects of mitigation measures."

This analysis is limited to identifying the relevant population characteristics around the candidate NIF sites and does not include an analysis of the waste streams from NIF operations. This approach is taken because wastes would be either stored on the site or "sent off site to a permitted treatment, storage, and disposal facility" (see Section I.3.6.8 of the PSA [DOE 1996, Appendix I]). It is assumed that the permitting process ensures that no high and adverse environmental or human health impacts would be caused by the treatment, storage, and disposal of such wastes. 
Methods, assumptions, and data sources are discussed in Section 3.2.7.2; results are discussed in Section 3.2.7.3.

\subsubsection{Definitions, Methods, and Assumptions}

Data on the minority and low-income characteristics of the populations potentially affected by the operation of NIF were taken from the 1990 U.S. Census of Population and Housing Summary Tape File 3-A on CD-ROM. Consequently, the definitions of minority and low-income correspond to the U.S. Bureau of the Census definitions employed in compiling those data. Specifically, "minority populations" include individuals who report themselves as belonging to any of the following racial groups: Black (reported their race as "Black or Negro," or reported entries such as "African American, Afro-American, Black Puerto Rican, Jamaican, Nigerian, West Indian, or Haitian"); American Indian, Eskimo, or Aleut; Asian or Pacific Islander; or "Other Race." In addition, individuals identifying themselves as of Hispanic origin are also included in the minority category. Hispanics can be of any race, however. To avoid double-counting minority Hispanic individuals, only white Hispanics were included in the number of racially based minorities in a tabulation, since nonwhite Hispanics had already been counted under the appropriate minority racial classifications.

"Low-income" status is based on census data definitions of individuals below the poverty line. For the 1990 census, for example, that included individuals in four-person families with 1989 incomes at or below $\$ 12,674$. Other poverty thresholds are provided by the Census Bureau for larger and smaller family sizes (U.S. Bureau of the Census 1994).

Interagency Working Group draft definitions exist for the phrases: "disproportionately high and adverse human health effects" and "substantially affect human health." Disproportionately high and adverse human health effects are those effects, including cumulative and/or synergistic effects, that exceed generally accepted levels of risk and fall disproportionately on minority or low-income populations. To substantially affect human health is to increase the measurable incidence of any specific illness, disease, or disorder to a level significantly higher than the national average. Both of these draft definitions may be changed in the final guidelines, which could occasion a revision of the findings reported here.

This section addresses the issue of the potential for impacts from NIF falling disproportionately on minorities or low-income populations. Two measures are employed to determine disproportionality: disproportionality of numbers of individuals at potential risk and disproportionality in the levels of potential impacts. The measure of disproportionality in numbers at risk involves comparing the population in the zone of potential impact with a reference population. For this purpose, the proportions or percentages of the potentially impacted populations (those 
residing within $80 \mathrm{~km}$ [50 mi] of the potential NIF locations) who are minority or low-income are compared to the corresponding states' populations who are minority or low-income.

The second measure of disproportionality, which focuses on the level of potential impacts, examines the characteristics of the populations within the zone of potential impact at various distances from the risk source. Distance from the risk source frequently means lower potential impacts or lower probability of impacts, especially with airborne pollutants or risk elements. This issue of relative concentrations of the two subpopulations of interest (minorities and low-income persons) within the zone of potential impact is addressed with the measure of distance of the block groups from the candidate NIF locations. Specifically, data exist for each block group concerning the distance from its centroid to the potential NIF location, and the percentages of the block group population consisting of minorities and low-income persons.

Correlation coefficients show both the direction, strength, and statistical significance of the relationships between the distance measure and the demographic characteristics of the block groups. Correlation coefficients can vary from -1 to +1 . A positive coefficient between distance and the percent minority or low-income population within a block group indicates that the farther the block group is away from the site, the higher is the percentage of minority or low-income persons within the block group. In that case, the minorities or low-income population would be less likely to be affected by impacts that decline with distance to the site, compared with the non-minority or nonlow-income population. A negative coefficient indicates the reverse - that minorities or low-income persons are disproportionately closer to the site compared with their non-minority or non-lowincome counterparts and, thus, are more likely to be adversely affected by impacts from the site, assuming such impacts are greater the closer the distance to the site. A coefficient that is statistically insignificant indicates that minorities or low-income persons are neither more nor less concentrated close to the candidate NIF locations relative to their non-minority or non-low-income counterparts.

\subsubsection{Findings and Discussion}

As noted above, two measures of potential disproportionality of impacts on minority or low-income populations are employed in this study. The first measure focuses on the percentages of minority and low-income populations living within the $80-\mathrm{km}(50-\mathrm{mi})$ zone of potential impact compared with the percentages of minority and low-income populations in the state as a whole within which the zone of potential impact is located. Table 3.7 presents the appropriate percentages for comparisons for the five candidate NIF sites. On the basis of this measure, potential environmental justice impacts exist only for minority populations in the $80-\mathrm{km}(50-\mathrm{mi})$ zones around the candidate NIF locations at LANL and NLVF. In each of these cases, minorities are overrepresented in the population within the $80-\mathrm{km}$ (50-mi) zone compared with the corresponding state percentages. Low-income populations, in contrast, are not over-represented among the populations within $80 \mathrm{~km}$ ( $50 \mathrm{mi}$ ) of any of the five candidate NIF locations. 
TABLE 3.7 Percentages of Populations within $80 \mathrm{~km}$ (50 mi) of National Ignition Facility Candidate Sites and of States in Which Those Sites Are Located, by Minority and Low-Income Status

\begin{tabular}{lccccc}
\hline & \multicolumn{2}{c}{$\begin{array}{c}\text { Percent } \\
\text { Minority }\end{array}$} & & \multicolumn{2}{c}{$\begin{array}{c}\text { Percent } \\
\text { Low Income }\end{array}$} \\
\cline { 2 - 3 } \cline { 5 - 6 } Site & NIF Site $^{\mathbf{a}}$ & State & & NIF Site $^{\mathbf{a}}$ & State \\
\hline LLNL & 41 & 43 & & 7 & 12 \\
LANL & 52 & 49 & & 14 & 21 \\
NTS & 14 & 21 & & 10 & 10 \\
NLVF & 25 & 21 & & 10 & 10 \\
SNL & 45 & 49 & & 15 & 21 \\
\hline
\end{tabular}

a As measured from the population living within $80 \mathrm{~km}$ $(50 \mathrm{mi})$ of the potential NIF site, based on populations living in census tracts with centroids within $80 \mathrm{~km}$ $(50 \mathrm{mi})$ of the candidate site.

Source: U.S. Bureau of the Census (1991).

The second measure of potential disproportionality of impacts focuses on the relative concentrations of minority and low-income populations close to the candidate NIF sites, compared with non-minority or non-low-income populations. Specifically, within the $80-\mathrm{km}$ (50-mi) zone of potential impact, are minorities or low-income persons located closer to the NIF site, on average, than are non-minorities or non-low-income persons? If so, then the assumption is made that a potential exists for disproportionate impacts because risks often increase with spatial proximity to the risk source. On the basis of this measure, the potential exists for disproportionate impacts on minorities around the candidate NIF locations at LLNL and NLVF, as shown by statistically negative correlation (-0.064 and -0.410$)$ coefficients for percent minority for these sites (Table 3.8). No such disproportionate concentrations of minorities occur close to any of the other three candidate NIF locations, as shown by the non-significant correlation coefficients in Table 3.8. Likewise, lowincome populations are not located disproportionately close to any of the candidate NIF locations, compared with non-low-income populations. The locations of block groups with above state average percentages of minority or low-income persons are shown in Figures 3.11 through 3.20. These maps graphically illustrate the findings discussed above.

As noted, the NLVF site is of particular concern for environmental justice, given that it has negative correlation coefficients between distance from the NIF location and both percentage 
TABLE 3.8 Correlation Coefficients for

Distance to National Ignition Facility

Candidate Sites and Percentage Minority or

Percentage Low-Income Populations ${ }^{a}$

\begin{tabular}{lccc}
\hline \multicolumn{1}{c}{ Site } & $\begin{array}{c}\text { Percent } \\
\text { Minority }\end{array}$ & $\begin{array}{c}\text { Percent } \\
\text { Low Income }\end{array}$ & Number \\
\hline LLNL & $-0.064^{*}$ & $+0.058^{*}$ & 5,161 \\
LANL & -0.151 & +0.023 & 235 \\
NTS & -0.395 & -0.366 & 26 \\
NLVF & $-0.410^{*}$ & -0.029 & 333 \\
SNL & +0.036 & +0.017 & 607 \\
\hline
\end{tabular}

a An asterisk indicates correlation is statistically significant at or beyond the 0.001 significance level.

Source: U.S. Bureau of the Census (1991).

minority and percentage low income (see Table 3.7). Thus, both minorities and low-income individuals are disproportionately close to the NLVF location. The individual at risk to maximum exposure to radionuclides is located $210 \mathrm{~m}(689 \mathrm{ft})$ west of the NLVF location (Table 4.4). The maximum threat zone for heavy gas and other releases from this location is between 75 and $239 \mathrm{~m}$ (246 and $784 \mathrm{ft}$ ) (Tables 4.8 through 4.11). In all cases, these maximum threat zones are within $1.6 \mathrm{~km}(1.0 \mathrm{mi})$ of the potential NIF location, or within the first circular zone for the NLVF site (Figures 3.21 and 3.22). As shown in these figures, the populations in these zones are both disproportionately minority and low-income, compared with the Nevada state averages. Consequently, potential environmental justice impacts are present at the NLVF site for both minority and low-income populations, on the basis of the findings presented here and in Tables 4.4 and 4.8 through 4.11.

In summary, for both measures of assessment, the potential exists for disproportionate impacts on minorities at the NLVF location. The potential also exists for disproportionate impacts on minorities at LLNL, but only because minorities are disproportionately concentrated close to the potential site. 


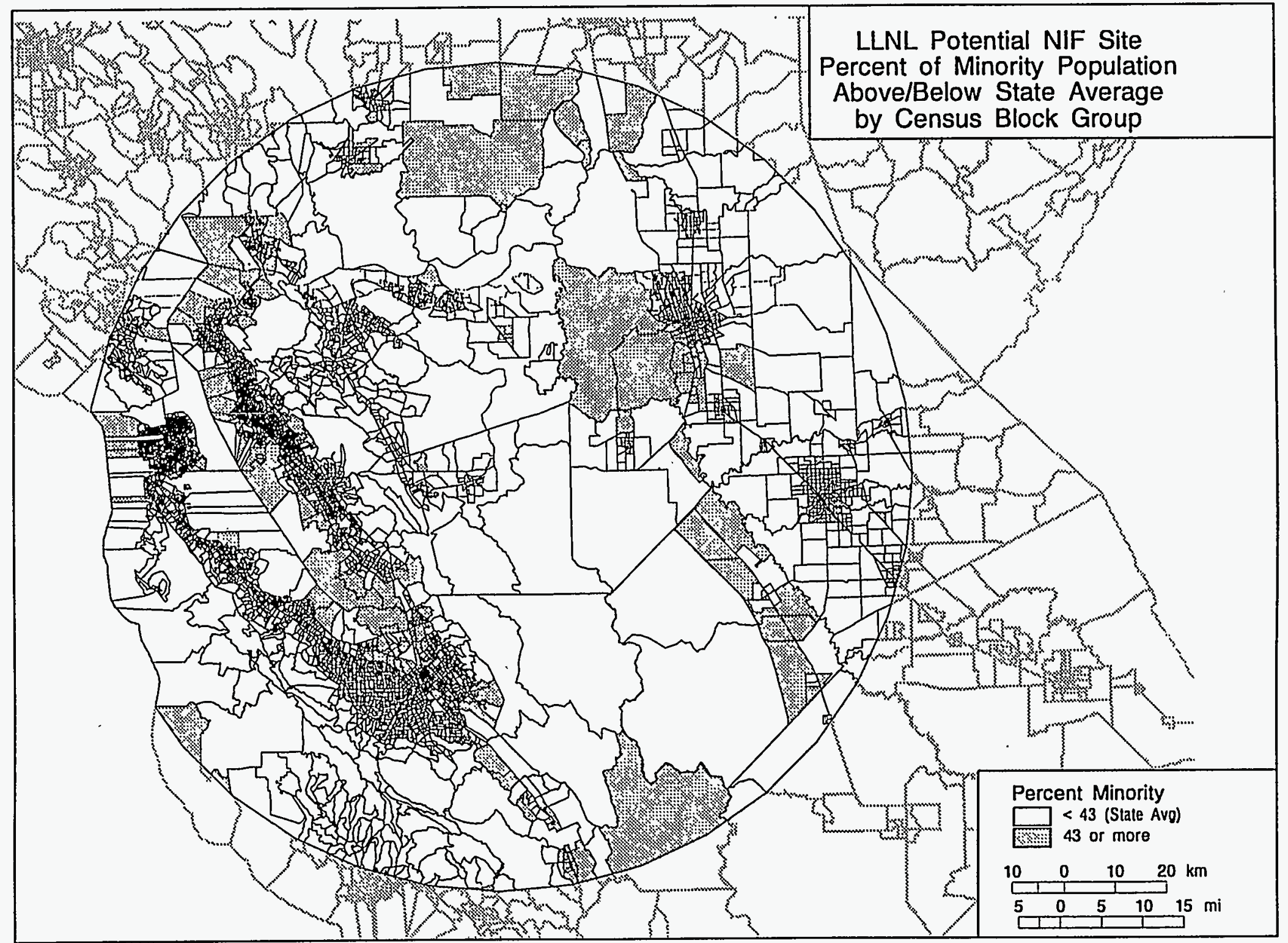




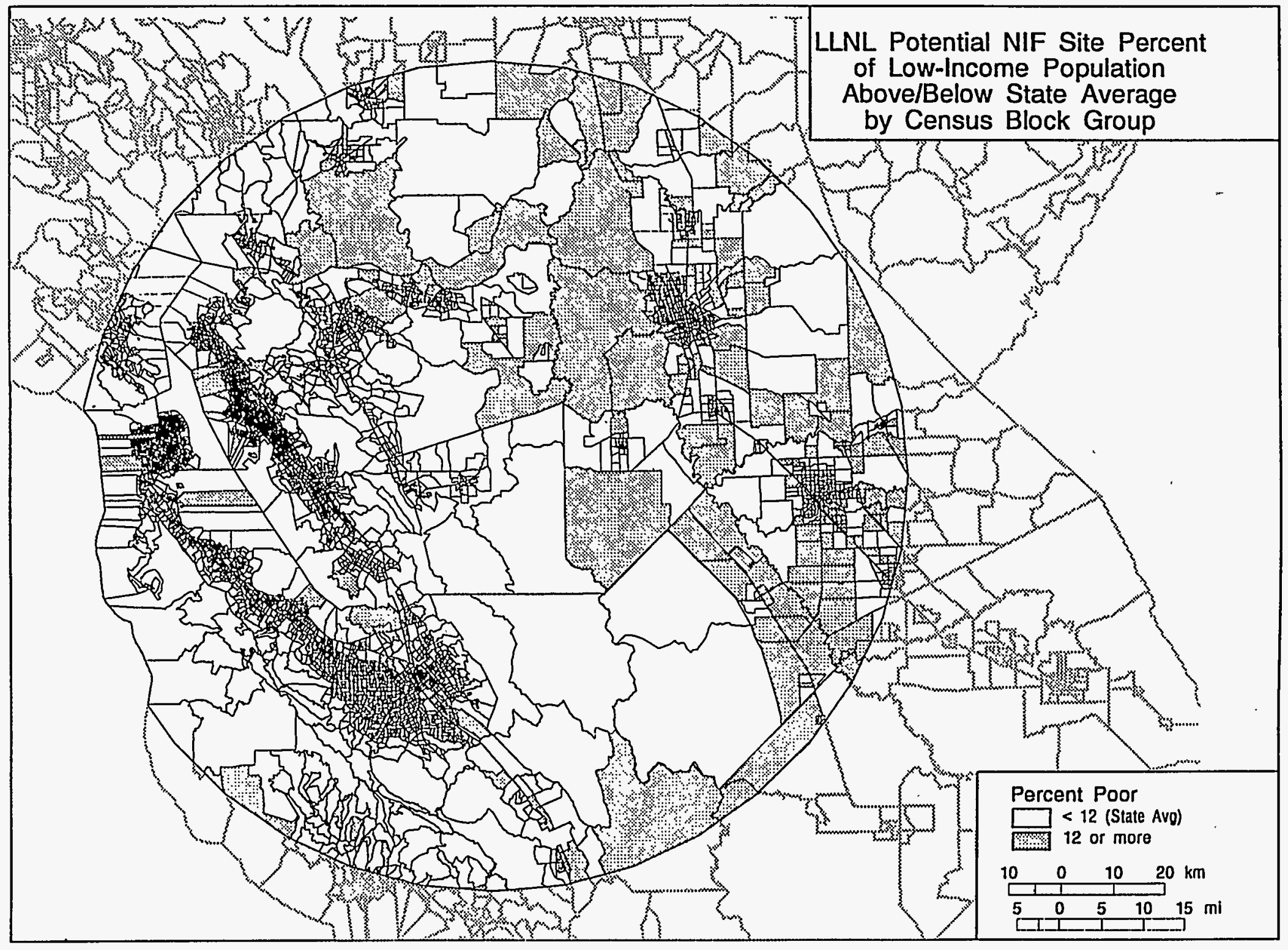

FIGURE 3.12 LLNL Potential NIF Site Percentage of Low-Income Population Above/Below State Average by Census Block Group 


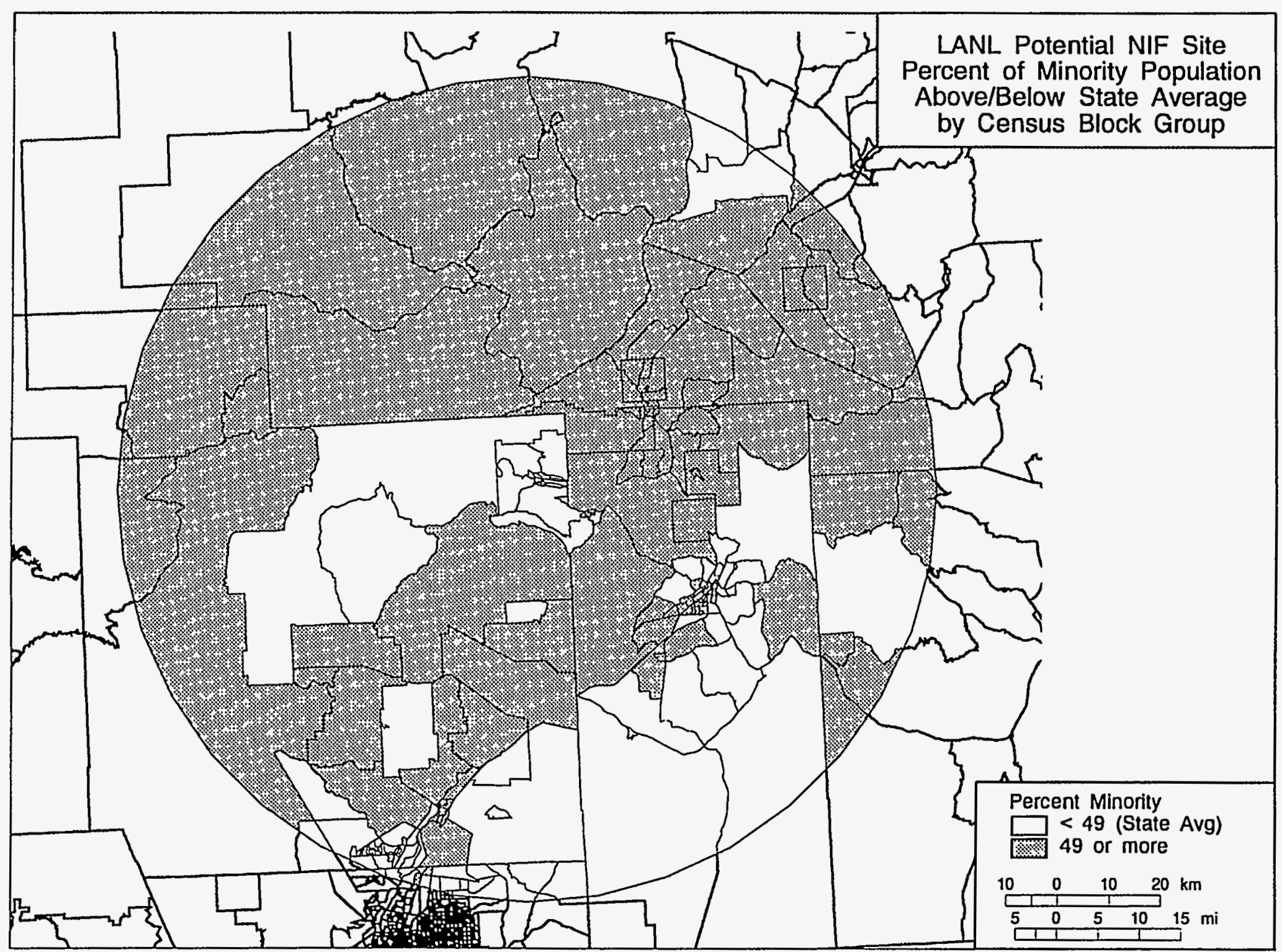

FIGURE 3.13 LANL Potential NIF Site Percentage of Minority Population Above/Below State Average by Census Block Group 


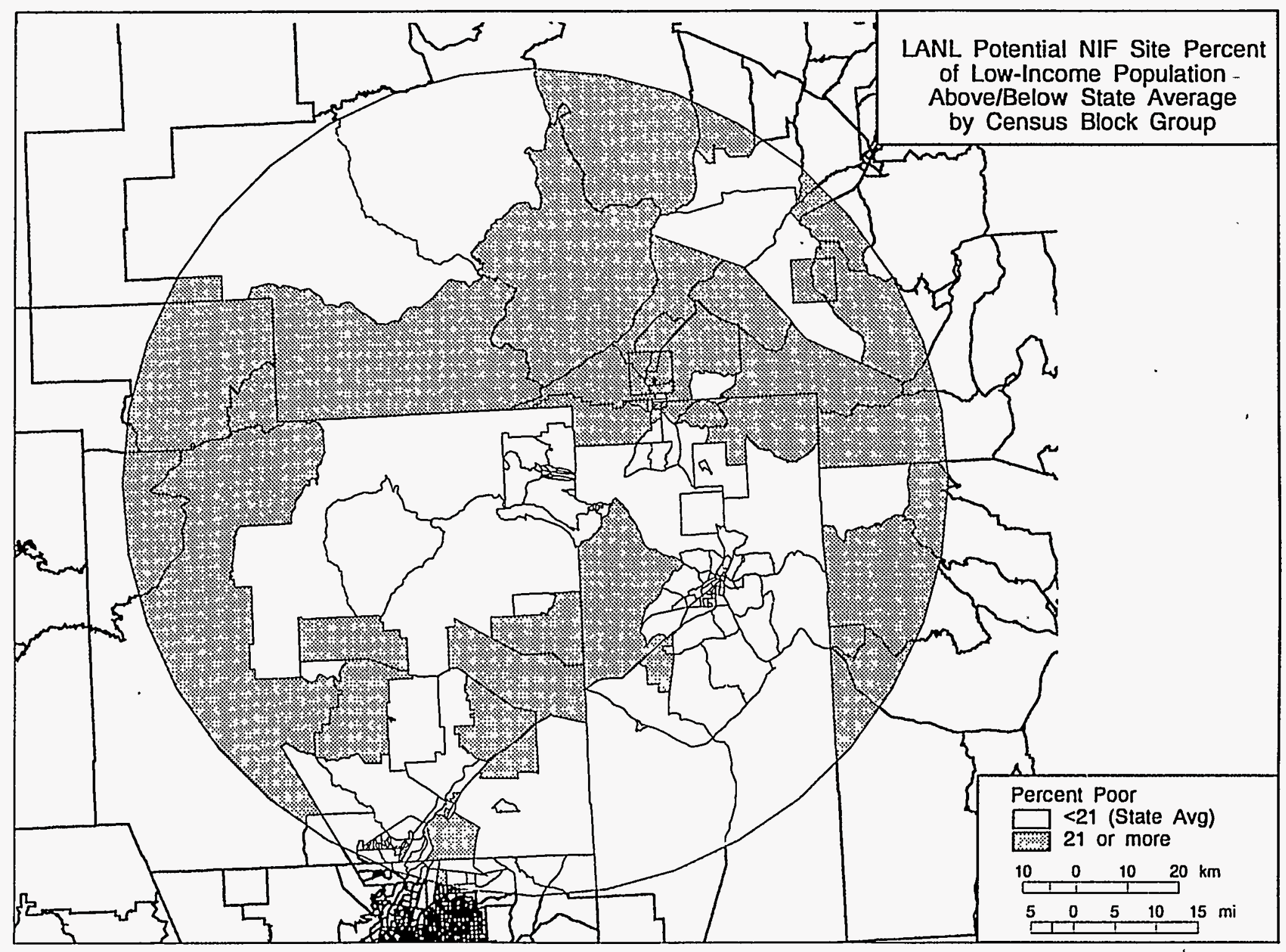

FIGURE 3.14 LANL Potential NIF Site Percentage of Low-Income Population Above/Below State Average by Census Block Group 


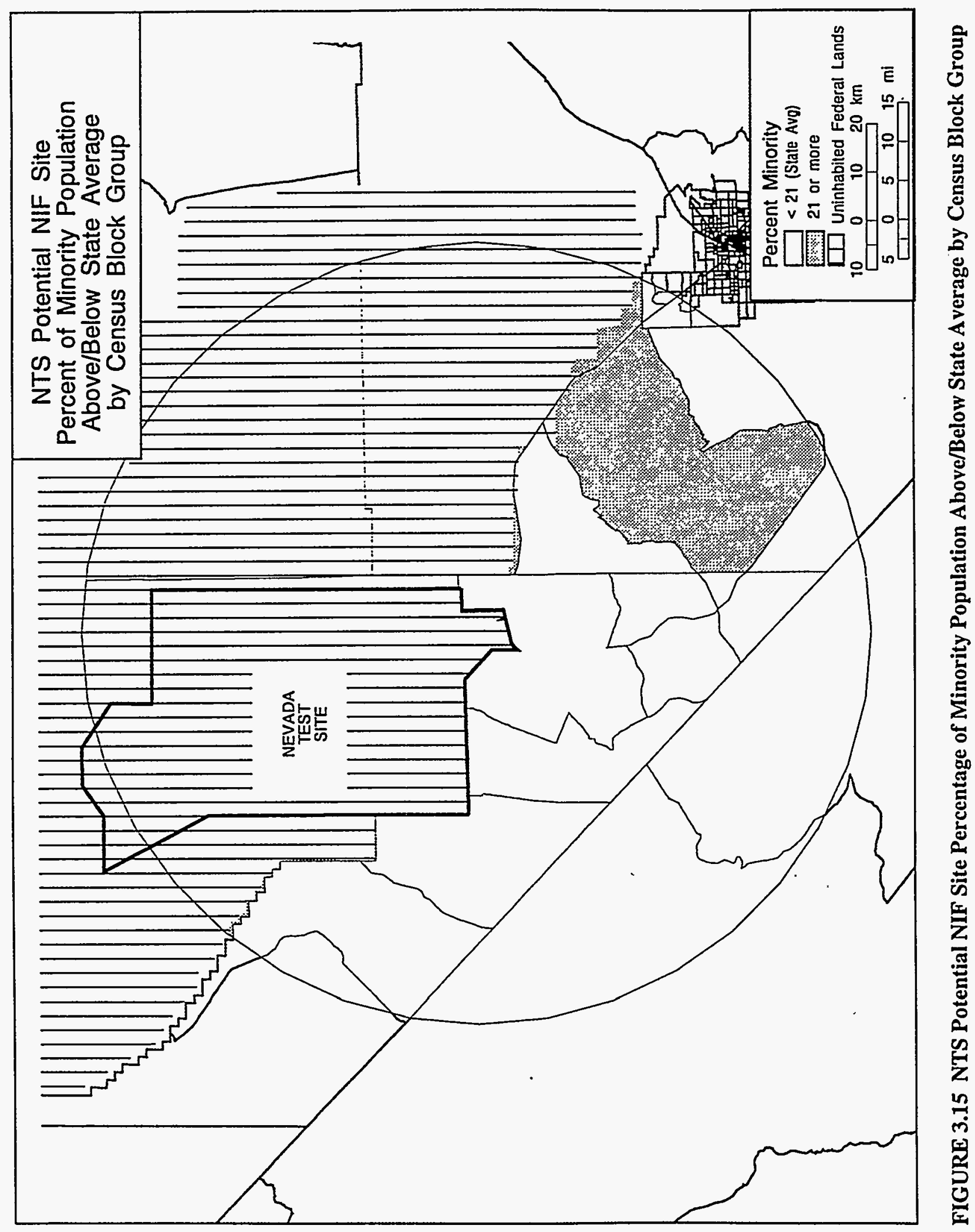




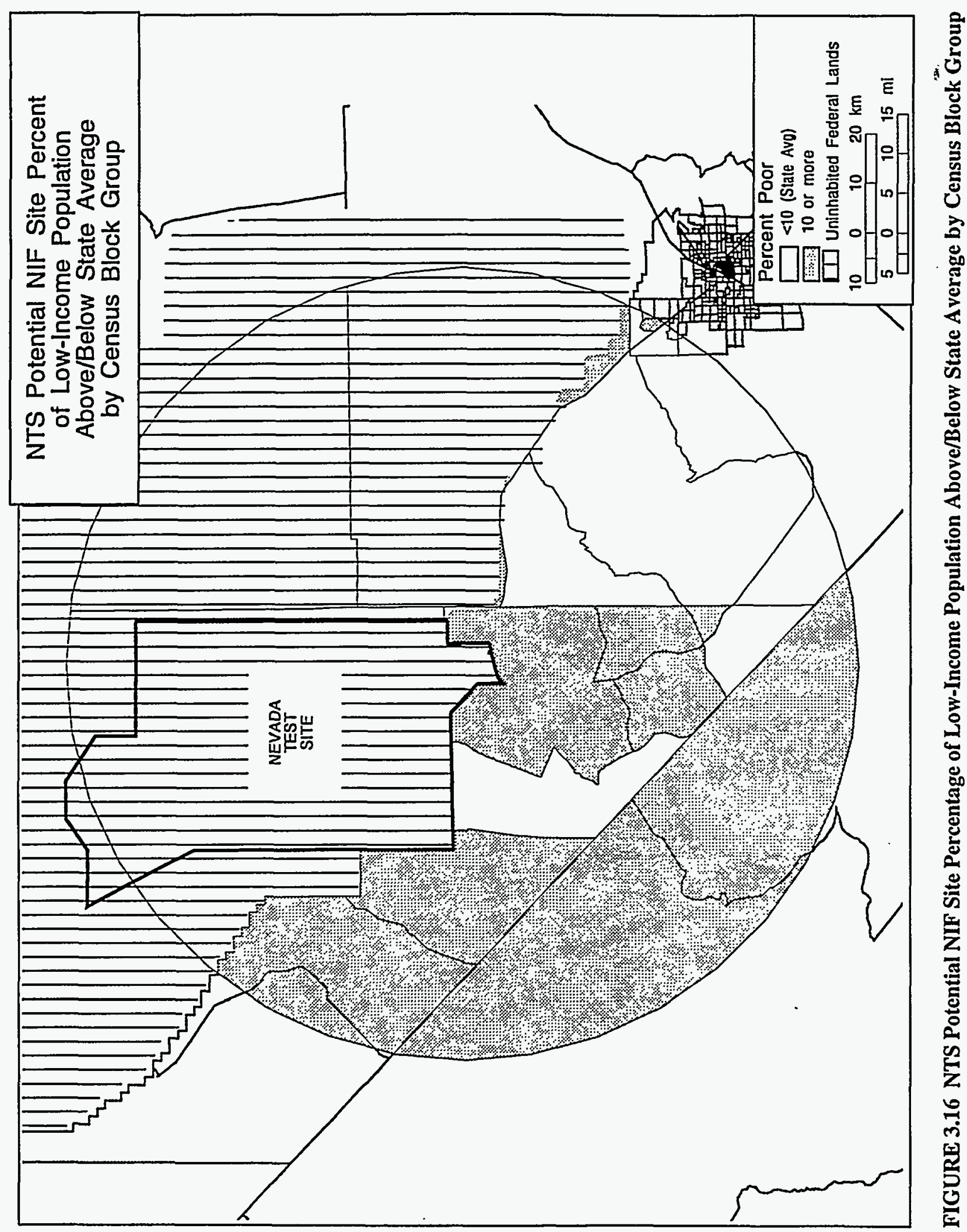




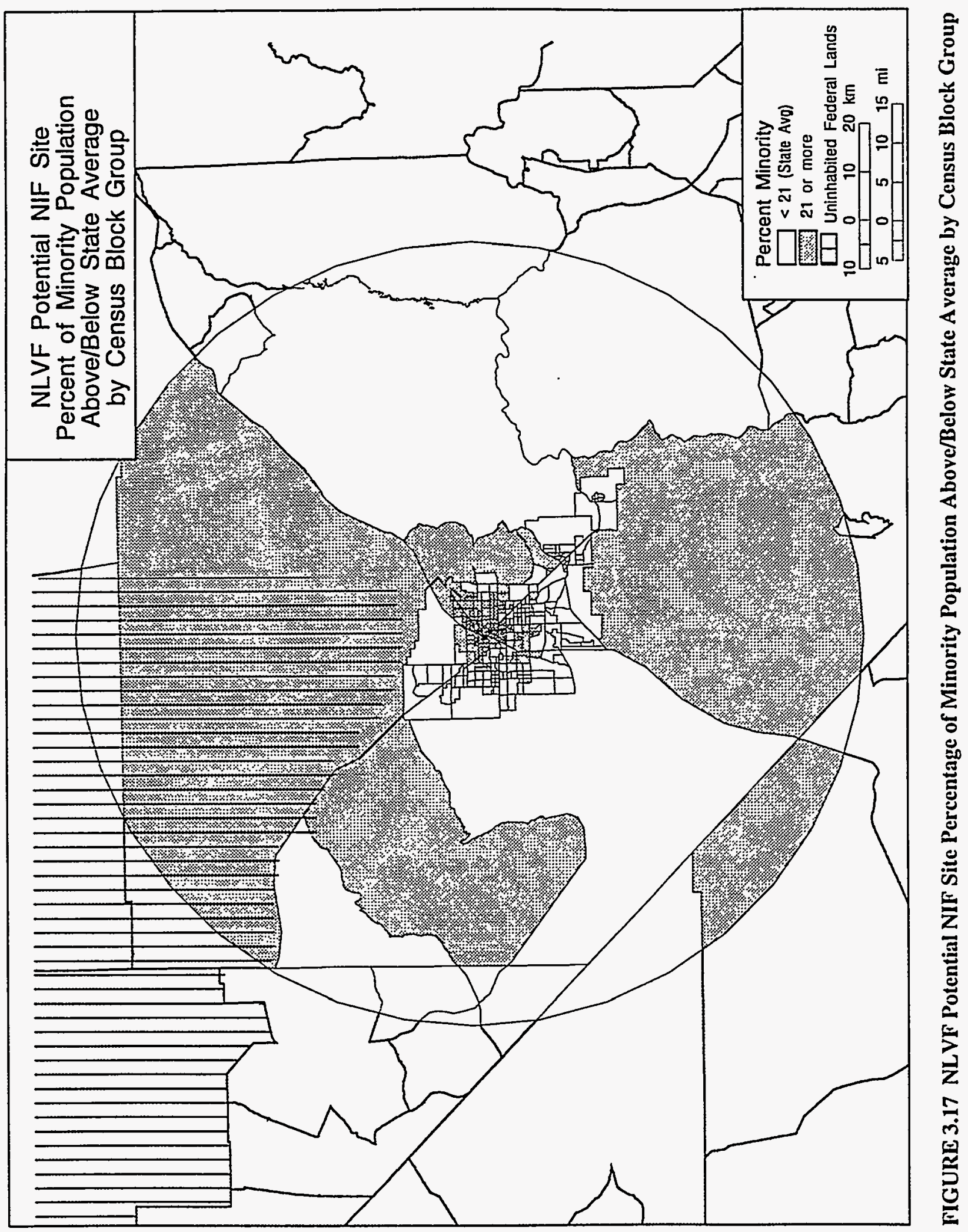




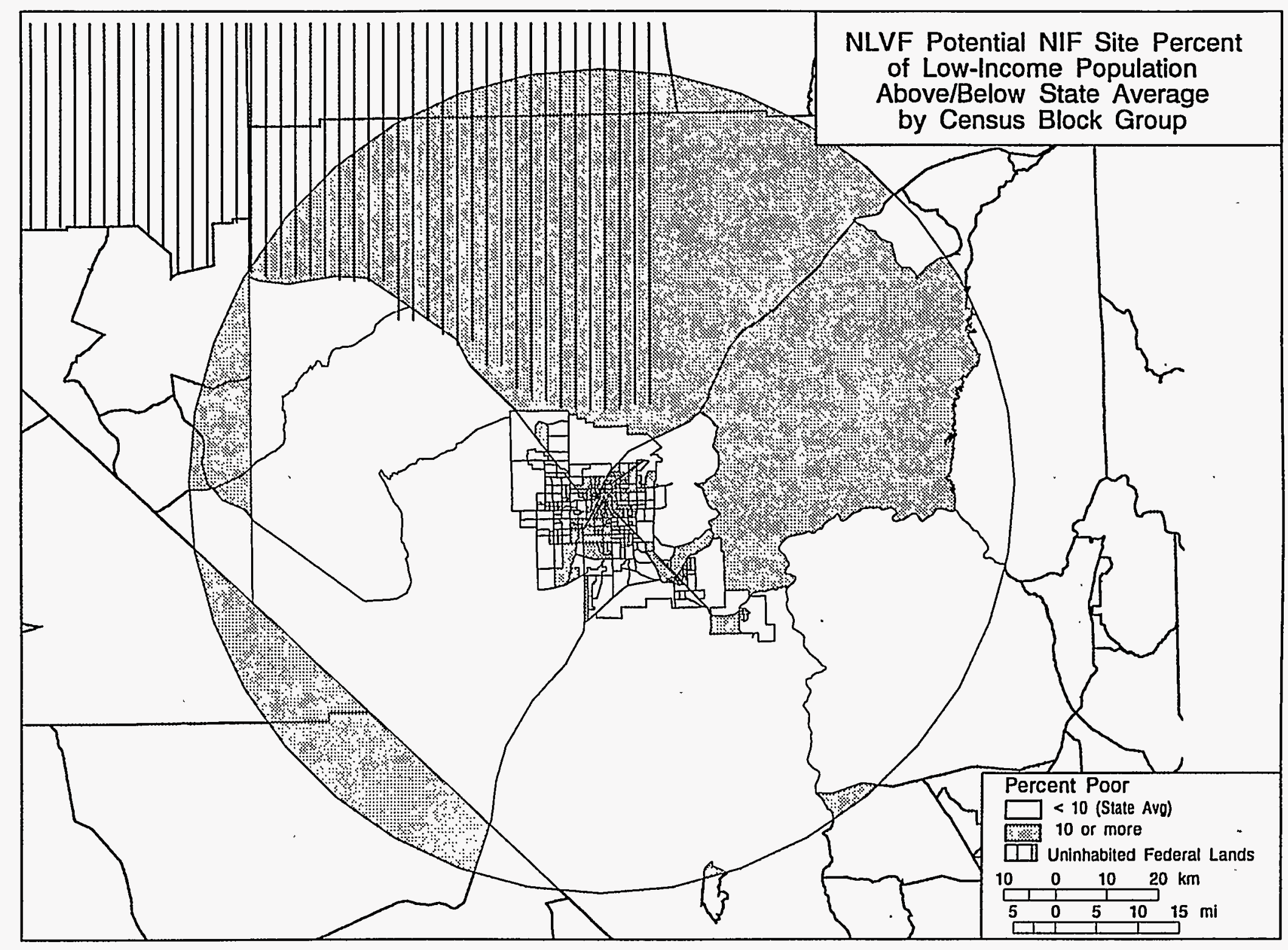
of Low-Income Population Above/Below State Average Census Block Group

FIGURE 3.18 NLVF Potential NIF Site Percentage of Low-Income Population Above/Below State Average by Census Block Group 


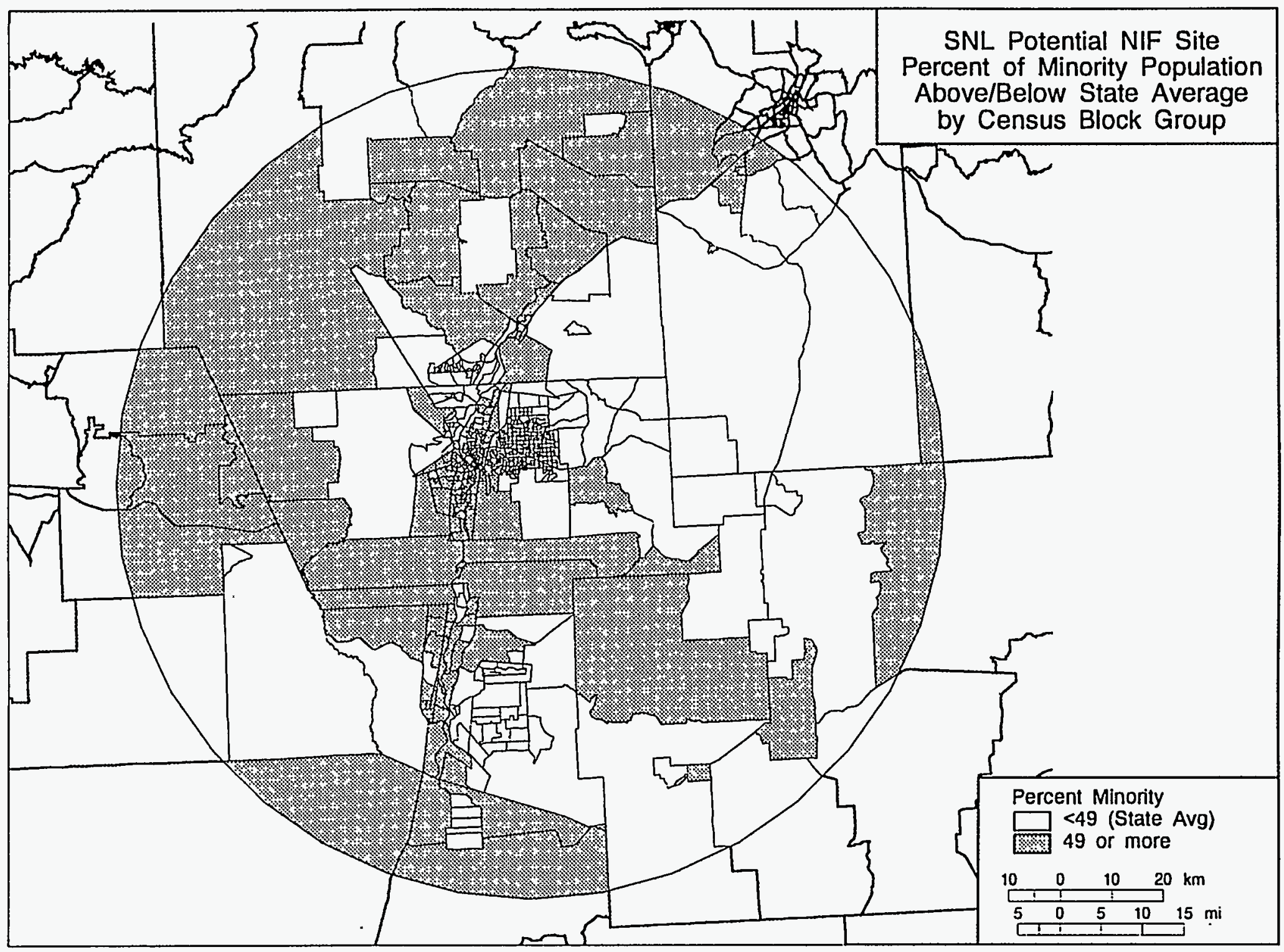

FIGURE 3.19 SNL Potential NIF Site Percentage of Minority Population Above/Below State Average by Census Block Group 


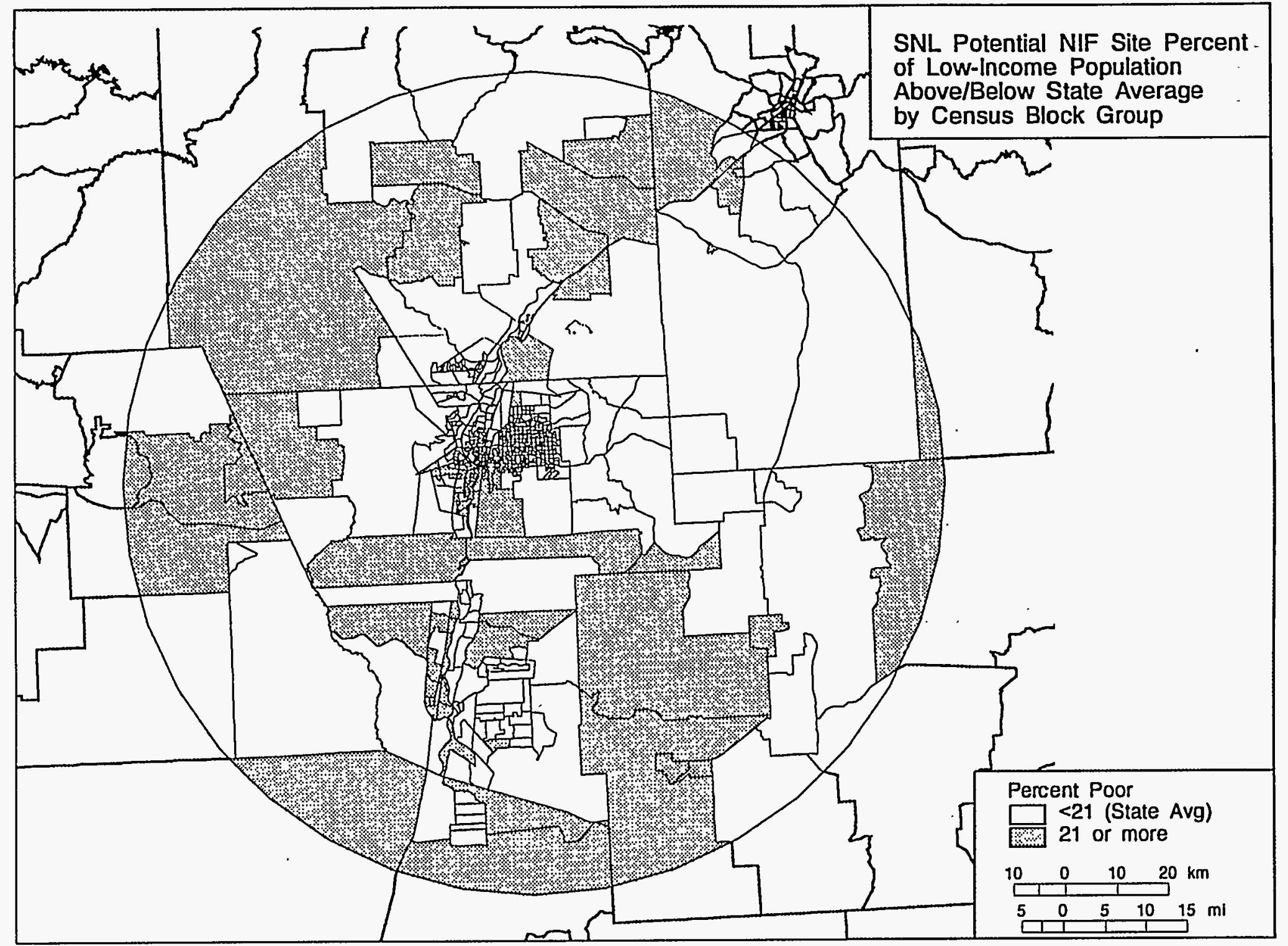

FIGURE 3.20 SNL Potential NIF Site Percentage of Low-Income Population Above/Below State Average by Census Block Group 


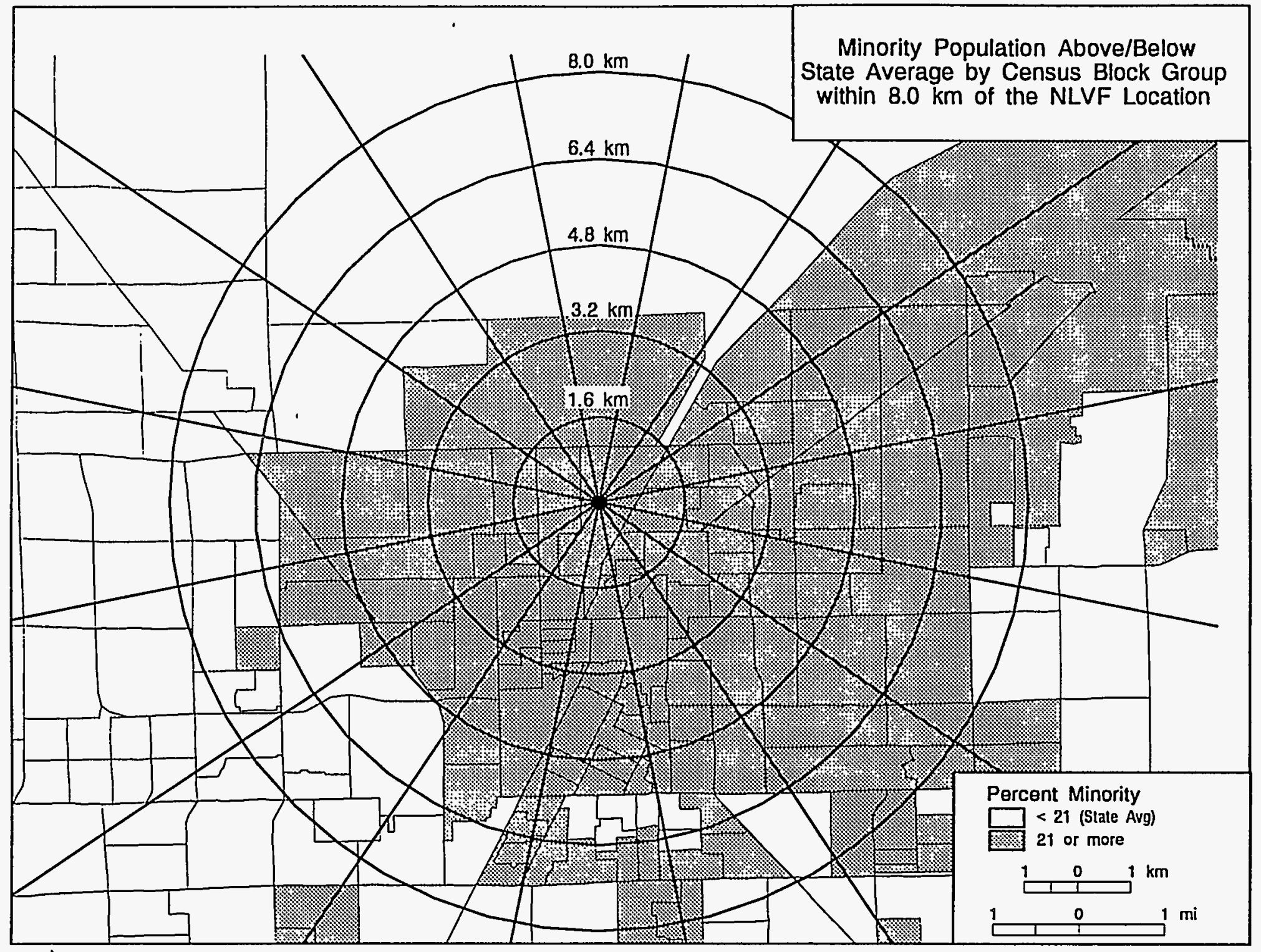




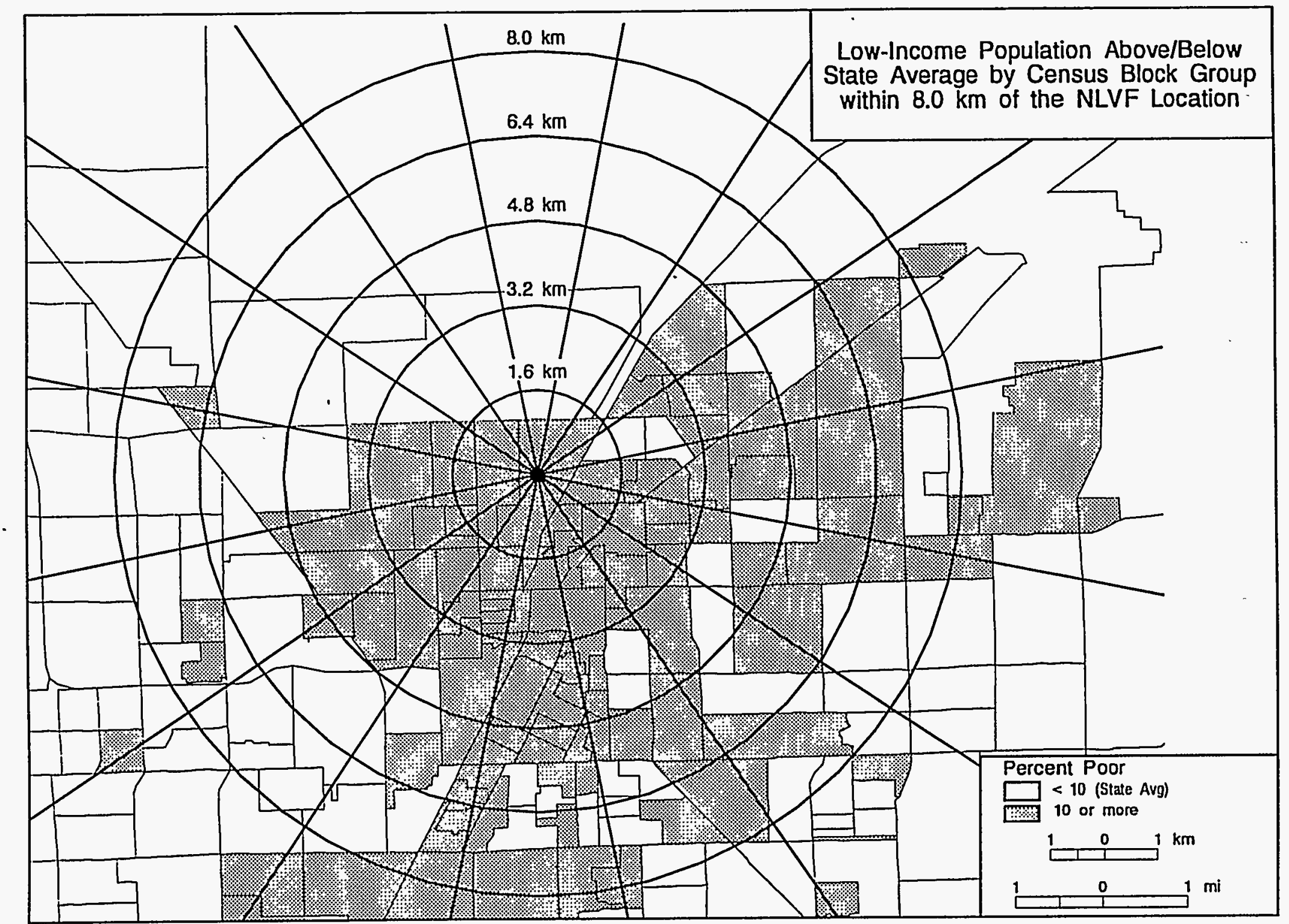




\subsection{REFERENCES FOR SECTION 3}

BEA - See Bureau of Economic Analysis.

Bureau of Economic Analysis, 1992, Regional Multipliers: A User Handbook for the Regional Input-Output Modeling System (RIMS II), 2nd Edition, U.S. Department of Commerce, Washington, D.C., May.

Bureau of Economic Analysis, 1995, Regional Input-Output Modeling System (RIMS II), U.S. Department of Commerce, Washington, D.C.

Bureau of Economic Analysis, 1996, Bureau of Economic Analysis Regional Projections to 2045, Vol. II, Metropolitan Statistical Areas, U.S. Department of Commerce, Washington, D.C.

DOE — See U.S. Department of Energy.

Lawrence Livermore National Laboratory, 1994, National Ignition Facility Conceptual Design Report, NIF-LLNL-94, L-16973-1, Livermore, Calif., May.

LLNL — See Lawrence Livermore National Laboratory.

Paisner, J., 1995, unpublished information, Lawrence Livermore National Laboratory, Livermore, Calif., July 14, 1995.

Repice, E., 1996, facsimile transmittal from Repice (Bureau of Economic Analysis, U.S. Department of Commerce, Washington, D.C.) to T. Bingaman (Brown and Root Environmental, Gaithersburg, Md.), June 5.

Transportation Research Board, 1985, Highway Capacity Manual, Special Report 209, Washington, D.C.

U.S. Bureau of the Census, 1991, 1990 Census of Population and Housing, U.S. Department of Commerce, Washington, D.C.

U.S. Bureau of the Census, 1994, Statistical Abstract of the United States: 1994, U.S. Department of Commerce, Washington, D.C.

U.S. Department of Energy, 1996, Programmatic Environmental Impact Statement for Stockpile Stewardship and Management, DOE/EIS-0236, Office of Reconfiguration, Washington, D.C.

White, R., 1995, unpublished information, Raytheon Services Nevada, Las Vegas, Nev. 


\section{RADIATION AND HAZARDOUS CHEMICALS}

This section describes the methods, data, and assumptions used to estimate radiological, hazardous chemical, and material transportation impacts that could result from the operation of NIF at the five alternative locations analyzed in the PSA (Appendix I, DOE 1996).

\subsection{RADIOLOGICAL IMPACT ASSESSMENT}

\subsubsection{Sources of Radiation}

NIF would house a powerful multi-beamline laser. During a fusion experiment, each beam of light would be focused and directed onto a target containing fusion fuel (a deuterium-tritium mixture). The fusion experiment would emit neutrons, energetic particles, debris, and $x$-rays. The energetic particles, debris, and $\mathrm{x}$-rays would be confined by the 5-m (16-ft) inner-radius aluminum alloy target chamber. The $0.1-\mathrm{m}(0.3-\mathrm{ft})$-thick target chamber would be housed in a cylindrical (30.5-m [100-ft] -diameter by 29.3-m [96-ft] -tall), reinforced-concrete building. The target chamber would be surrounded by a $0.4-\mathrm{m}$ (1.3-ft) -thick concrete shield. Most neutrons would travel through the target chamber and local shielding structure before being stopped by concrete walls. Some neutrons would activate the target chamber, gases in the air, and concrete and reinforcing bars (rebars) in the walls. The cylindrical Target Area Building would have a $1.83-\mathrm{m}$ (6.0-ft) -thick concrete wall and a $1.22-\mathrm{m}(4.0-\mathrm{ft})$-thick concrete roof to shield direct radiation of neutrons and their induced gamma rays. The switchyard building would have a $1.22-\mathrm{m}$ (4.0-ft) -thick concrete wall and a $0.61-\mathrm{m}(2.0-\mathrm{ft})$-thick concrete roof. With such shielding design, direct radiation exposure to the general public would be negligibly small (Singh et al. 1995). Most of the unburned tritium would be exhausted to the tritium processing system, while a small amount would be adsorbed onto the target chamber wall.

During normal NIF operations, up to 1,200 fusion experiments (with $25 \%$ involving tritium) would be conducted each year. These experiments would result in chronic atmospheric releases of small quantities of tritium and some radionuclides produced from activation of gases in the air.

For impact analysis, a bounding accident was postulated on the basis of a preliminary hazard analysis. The bounding accident assumed that a severe earthquake occurs during a maximumcredible-yield fusion experiment. With a small number of maximum-yield experiments projected for each year of NIF operation, the frequency of the accident would be less than $2 \times 10^{-8} / \mathrm{yr}$ (Brereton 1995). It was assumed that beamlines leading into the target chamber and building structures other than the Target Area Building would fail during the postulated earthquake. The collapsed beamlines 
and building structures would provide a pathway for acute atmospheric releases of tritium in the tritium processing system, activated gases in the air, and activated material in the target chamber.

Although radiological impacts from the postulated accident described above would bound all other potential accidents, a brief discussion of a possible light aircraft crash event is warranted. The likelihood of that event's occurring at the Target Area Building was estimated to be approximately $4 \times 10^{-5} / \mathrm{yr}$ (Kimura 1996). The thick, reinforced concrete structure of this building would withstand the impact of a direct aircraft hit. Thus, no release of radioactive material would be expected. However, the NIF Diagnostics Building, which would have a metal frame with steel siding, could be severely damaged if it were to be hit by an aircraft. As a result, a total of up to $75 \mathrm{Ci}$ of tritium in the target handling area could be released. The impact from this tritium release would be bounded by the postulated bounding accident already analyzed in this study.

The released radionuclides would be dispersed and transported through air in patterns determined by meteorological conditions and would reach downwind humans directly or through the foods they eat. Potential routes through which radiation can enter the human body include external exposure to, inhalation of, or ingestion of radionuclides.

\subsubsection{Assessment Methods}

Radiological impacts were estimated in terms of potential radiation doses received by a human body and the resulting risk of cancer fatalities. The cancer fatality statistics referred to in this study are latent cancer fatalities, which are of deaths from cancer that occur within 30 years following exposure to radiation.

The GENII computer program (Napier et al. 1988) was used to model chronic and acute releases of radionuclides and to calculate radiation doses to the surrounding public and workers at the five candidate sites during normal operations and under postulated accident conditions at the NIF location. The GENII program models atmospheric dispersion of radionuclides with a straight-line Gaussian-plume model. Radiation doses calculated with GENII were converted into health effects on the basis of the 1990 Recommendations of the International Commission on Radiological Protection (Publication 60) (ICRP 1991). The conversion factors are $5 \times 10^{-4}$ cancer fatality per person-rem for the public and $4 \times 10^{-4}$ for workers. 


\subsubsection{Model Input}

\subsubsection{Source Term Data}

Tables 4.1 and 4.2 list the source terms, or the quantities of radionuclides released to the environment over a period of time, for both the Conceptual Design Option and the Enhanced Option. These source terms were used to estimate the impacts of normal operations and a postulated accident.

\subsubsection{Meteorological Data}

Table 4.3 lists available site-specific meteorological data used in atmospheric dispersion calculations for releases from NIF at the five candidate sites.

\subsubsection{Population Data}

Data from the 1990 census (U.S. Bureau of the Census 1991) were used to derive population distributions around the sites, and current workforce information was used to estimate

TABLE 4.1 Radiological Source Terms from Normal National Ignition Facility Operations

\begin{tabular}{llcc}
\hline & & Quantity Released (Ci/yr) \\
\cline { 3 - 4 } & & $\begin{array}{c}\text { Conceptual } \\
\text { Design } \\
\text { Option }\end{array}$ & $\begin{array}{c}\text { Enhanced } \\
\text { Option }\end{array}$ \\
\hline Radionuclide & Half-Life & 10 & 30 \\
Tritium & $12 \mathrm{yr}$ & 21 & 86 \\
Nitrogen-13 & $10 \mathrm{~min}$ & 41 & 170 \\
Nitrogen-16 & $7.1 \mathrm{~s}$ & 0.3 & 1.4 \\
Sulfur-37 & $5.0 \mathrm{~min}$ & 0.3 & 1.4 \\
Chlorine-40 & $1.4 \mathrm{~min}$ & 17 & 54 \\
Argon-41 & $1.8 \mathrm{~h}$ & $4.5 \times 10^{-4}$ & $1.5 \times 10^{-3}$ \\
Carbon-14 & $5,700 \mathrm{yr}$ & & \\
\hline
\end{tabular}

Source: Singh et al. (1995). 
TABLE 4.2 Radiological Source Terms for a

Postulated Accident at the National Ignition Facility

\begin{tabular}{|c|c|c|c|}
\hline \multirow[b]{2}{*}{ Radionuclide } & \multirow[b]{2}{*}{ Half-Life } & \multicolumn{2}{|c|}{ Quantity Released (Ci) } \\
\hline & & $\begin{array}{l}\text { Conceptual } \\
\text { Design } \\
\text { Option }\end{array}$ & $\begin{array}{c}\text { Enhanced } \\
\text { Option }\end{array}$ \\
\hline Tritium & $12 \mathrm{yr}$ & 300 & 500 \\
\hline Nitrogen-13 & $10 \mathrm{~min}$ & 7.9 & 24 \\
\hline Nitrogen-16 & $7.1 \mathrm{~s}$ & 150 & 570 \\
\hline Sulfur-37 & $5.0 \mathrm{~min}$ & $2.0 \times 10^{-1}$ & $6.0 \times 10^{-1}$ \\
\hline Chlorine- 40 & $1.4 \mathrm{~min}$ & $6.0 \times 10^{-1}$ & 1.7 \\
\hline Argon-41 & $1.8 \mathrm{~h}$ & 1.4 & 3.3 \\
\hline Carbon-14 & $5,700 \mathrm{yr}$ & $2.4 \times 10^{-5}$ & $5.5 \times 10^{-5}$ \\
\hline Sodium-24 & $15 \mathrm{~h}$ & $4.8 \times 10^{-5}$ & $4.8 \times 10^{-4}$ \\
\hline Magnesium-27 & $9.4 \mathrm{~min}$ & $3.0 \times 10^{-3}$ & $3.0 \times 10^{-2}$ \\
\hline Aluminum-28 & $2.2 \mathrm{~min}$ & $4.0 \times 10^{-3}$ & $3.0 \times 10^{-2}$ \\
\hline Aluminum-29 & $6.5 \mathrm{~min}$ & $2.5 \times 10^{-6}$ & $2.5 \times 10^{-5}$ \\
\hline Vanadium-52 & $3.8 \mathrm{~min}$ & $5.0 \times 10^{-3}$ & $1.0 \times 10^{-2}$ \\
\hline Chromium-51 & $28 \mathrm{~d}$ & $1.0 \times 10^{-6}$ & $8.5 \times 10^{-6}$ \\
\hline Chromium-55 & $3.5 \mathrm{~min}$ & $2.0 \times 10^{-3}$ & $5.0 \times 10^{-3}$ \\
\hline Manganese-54 & $310 \mathrm{~d}$ & $5.5 \times 10^{-7}$ & $5.5 \times 10^{-5}$ \\
\hline Manganese-56 & $2.6 \mathrm{~h}$ & $7.0 \times 10^{-4}$ & $2.0 \times 10^{-3}$ \\
\hline Cobalt-58 & $71 \mathrm{~d}$ & $1.3 \times 10^{-8}$ & $2.5 \times 10^{-7}$ \\
\hline Cobalt -60 & $5.2 \mathrm{yr}$ & $2.4 \times 10^{-8}$ & $1.1 \times 10^{-5}$ \\
\hline Cobalt- $60 \mathrm{~m}$ & $10 \mathrm{~min}$ & $9.0 \times 10^{-3}$ & $2.0 \times 10^{-2}$ \\
\hline Cobalt-62m & $14 \mathrm{~min}$ & $1.0 \times 10^{-3}$ & $2.0 \times 10^{-3}$ \\
\hline Nickel-57 & $36 \mathrm{~h}$ & $7.5 \times 10^{-8}$ & $1.7 \times 10^{-7}$ \\
\hline Copper-62 & $9.7 \mathrm{~min}$ & $2.1 \times 10^{-1}$ & $4.8 \times 10^{-1}$ \\
\hline Copper-64 & $13 \mathrm{~h}$ & $3.0 \times 10^{-3}$ & $6.0 \times 10^{-3}$ \\
\hline Copper-66 & $5.1 \mathrm{~min}$ & $5.9 \times 10^{-4}$ & $1.0 \times 10^{-3}$ \\
\hline Zinc-63 & $38 \mathrm{~min}$ & $3.6 \times 10^{-7}$ & $3.6 \times 10^{-6}$ \\
\hline Platinum-197 & $18 \mathrm{~h}$ & $3.1 \times 10^{-6}$ & $7.0 \times 10^{-6}$ \\
\hline Gold-196 & $6.2 \mathrm{~d}$ & $4.5 \times 10^{-4}$ & $2.0 \times 10^{-3}$ \\
\hline Gold-198 & $2.7 \mathrm{~d}$ & $5.0 \times 10^{-6}$ & $1.3 \times 10^{-5}$ \\
\hline
\end{tabular}

Source: Brereton (1995). 
TABLE 4.3 Site-Specific Meteorological Data

\begin{tabular}{lll}
\hline \multicolumn{1}{c}{ Site } & \multicolumn{1}{c}{ Tower Location } & Data Period \\
\hline LLNL & On-site & $1990-1994$ \\
LANL & TA-6, on-site & $1990-1994$ \\
NTS & MEDA DRA, on-site & $1978-1988$ \\
NLVF & Las Vegas Int'l. Airport & $1987-1991$ \\
SNL & On-site & 1994 \\
\hline
\end{tabular}

worker distribution at the sites. The population was spatially distributed on a circular grid with 16 directions and 10 radial distances up to $80 \mathrm{~km}$ (50 mi). The grid was centered on the proposed NIF location at each candidate site.

\subsubsection{Locations of Maximally Exposed Individual}

Table 4.4 lists the distance and direction of the maximally exposed individual (MEI) relative to the proposed NIF location at the five candidate sites. The MEI is a hypothetical nearby individual who would receive the highest radiation dose of all the surrounding general population.

\subsubsection{Assumptions}

Key assumptions used in estimating the radiological impacts were as follows:

- The release of radionuclides is at $27 \mathrm{~m}(89 \mathrm{ft})$ above ground during normal NIF operations, and at ground level under accident conditions.

- All tritium releases are in the form of tritiated water.

- The absolute humidity is $0.009 \mathrm{~L} / \mathrm{m}^{3}\left(0.002 \mathrm{gal} / \mathrm{yd}^{3}\right)$ for $\mathrm{LLNL}$ and $0.005 \mathrm{~L} / \mathrm{m}^{3}\left(0.001 \mathrm{gal} / \mathrm{yd}^{3}\right)$ for other sites.

- Radionuclides of either small quantity or short half-life are not included in GENII calculations. The radiation dose that they contribute to the surrounding public is negligible (Brereton 1995). 
- The accident occurs immediately before the annual crop harvest.

- Radiation dose from resuspension of particulates after deposition is negligible.

- No prior deposition of radionuclides on ground surfaces has occurred.

\subsection{HAZARDOUS CHEMICAL IMPACT ASSESSMENT}

TABLE 4.4 Location of Maximally Exposed Individual ${ }^{\mathrm{a}}$

\begin{tabular}{lcc}
\hline \multicolumn{1}{c}{ Site } & Distance (m) & Direction \\
\hline LLNL & 400 & $\mathrm{E}$ \\
LANL & 1,620 & $\mathrm{NNE}$ \\
NTS & 20,000 & SSW \\
NLVF & 210 & $\mathrm{~W}$ \\
SNL & 1,864 & $\mathrm{~N}$ \\
\hline \multicolumn{4}{l}{} \\
a Distance and direction relative to \\
proposed NIF location.
\end{tabular}

\subsubsection{Assessment Procedure}

The normal operation of NIF would require the use of numerous chemicals. The assessment of potential impacts of those chemicals began by first determining which are potentially hazardous because of toxicity or other harmful effects, such as asphyxiation. The next step was to identify scenarios that could cause an accidental release of those chemicals. Release scenarios were identified and evaluated for both Conceptual Design and Enhanced options for each of the five candidate NIF sites.

Five bounding chemical release accidents were developed for evaluation. These events were derived from the Preliminary Hazards Analysis (PHA) (Brereton 1993). They were derived from general considerations of the NIF design and are, therefore, applicable to any of the five candidate NIF sites. In addition, an accidental propane gas release was evaluated for the NTS (exclusively) as a sixth scenario. The large propane storage tanks are unique to the NTS and are independent of NIF itself.

Estimated inventories of chemicals for the Conceptual Design and Enhanced options are provided in Tables 4.5 and 4.6, respectively. The inventories include agents for cleaning, electrical equipment use, optics treatment, and fire wall protection. The inventories were examined to determine which chemicals have hazardous or exposure criteria thresholds. The criteria were weighted against release amounts to determine which chemicals could possibly present risk. Generally, NIF would maintain relatively higher inventories of materials with lower toxicity. Most chemicals can be conservatively eliminated from consideration by jointly weighting these two factors. On the basis of these combined factors, five materials were identified as potential sources of concern under four accident scenarios. These materials and scenarios apply generally to NIF wherever its location. Parameters for the Conceptual Design and Enhanced release scenarios are summarized in Table 4.7. 
TABLE 4.5 Estimated Chemical Inventories for the National Ignition Facility Conceptual Design Option

\begin{tabular}{|c|c|c|}
\hline Chemical & Source & Quantity \\
\hline Acetone & Solvent for cleaning & $38 \mathrm{~L}(30 \mathrm{~kg})$ \\
\hline $\begin{array}{l}\text { Alumina } \\
\text { (aluminum oxide) }\end{array}$ & Particulates from first wall & $6.7 \mathrm{~kg}$ \\
\hline $\begin{array}{l}\text { Ammonium hydroxide } \\
(50 \% \mathrm{wt})\end{array}$ & Optics treatment & $\begin{array}{l}38 \mathrm{~L}(-38 \mathrm{~kg} \text { ammonia- } \\
\text { equivalent) }\end{array}$ \\
\hline Copper & Particulates from cryostat & $<0.5 \mathrm{~kg}$ \\
\hline Ethanol & $\begin{array}{l}\text { Solvent for cleaning and optics } \\
\text { treatment }\end{array}$ & $1,514 \mathrm{~L}^{\mathrm{a}}(\sim 1,200 \mathrm{~kg})$ \\
\hline Fluorinert $^{b}$ & Optics treatment & $151 \mathrm{~L}$ \\
\hline \multirow[t]{2}{*}{ Fused silica ${ }^{c}$} & $\begin{array}{l}\text { Particulates from ablated debris } \\
\text { shield }\end{array}$ & $2.1 \mathrm{~kg}$ \\
\hline & $\begin{array}{l}\text { Lenses, windows, debris shields, } \\
\text { deformable mirrors }\end{array}$ & $96.5 \mathrm{~kg}^{\mathrm{d}}$ \\
\hline Gold & Particulates from hohlraum & $<1 \mathrm{~kg}$ \\
\hline Hafnium oxide & Optics coating & $0.07 \mathrm{~kg}^{\mathrm{e}}$ \\
\hline $\begin{array}{l}\text { Hydrofluoric acid } \\
(151 \mathrm{~L} \text { at } 1 \% \mathrm{wt}, \\
1.9 \mathrm{~L} \text { at } 52 \% \mathrm{wt})\end{array}$ & Optics treatment & $\begin{array}{l}208 \mathrm{~L} \mathrm{(} 22 \mathrm{~kg} \text { hydrogen } \\
\text { fluoride) }\end{array}$ \\
\hline $\begin{array}{l}\text { KDP (potassium } \\
\text { dihydrogen phosphate) }\end{array}$ & Frequency conversion crystals & \\
\hline $\mathrm{KH}_{2} \mathrm{PO}_{4}$ & - & $3.2 \mathrm{~kg}$ \\
\hline $\begin{array}{c}\mathrm{KD}_{1.2} \mathrm{H}_{0.8} \mathrm{PO}_{4} \\
\text { (deuterated) }\end{array}$ & & $7.6 \mathrm{~kg}$ \\
\hline Mercury & Ignitrons $\mathrm{s}^{\mathrm{f}}$ & $450 \mathrm{~L}\left(\sim 6,200 \mathrm{~kg}^{\mathrm{g}}\right)$ \\
\hline
\end{tabular}


TABLE 4.5 (Cont.)

\begin{tabular}{|c|c|c|}
\hline Chemical & Source & Quantity \\
\hline $\begin{array}{l}\text { Sodium hydroxide } \\
\text { ( } 189 \mathrm{~L} \text { at } 3 \% \mathrm{wt}, 76 \mathrm{~L} \\
\text { at } 50 \% \mathrm{wt} \text {, or solid pellets) }\end{array}$ & Cleaner for debris shields & $\begin{array}{l}265 \mathrm{~L} \text { ( }-82 \mathrm{~kg} \text { sodium } \\
\text { hydroxide) }\end{array}$ \\
\hline Stainless steel & Particulates from target positioner & $<0.2 \mathrm{~kg}$ \\
\hline Teflon $^{\text {h }}$ & Optics treatment & $3 \mathrm{~kg}$ \\
\hline Tetraethylorthosilicate $^{\mathrm{i}}$ & Optics treatment & $379 \mathrm{~L}(353 \mathrm{~kg})$ \\
\hline Zirconium oxide & Optics coating & $0.003 \mathrm{~kg}$ \\
\hline
\end{tabular}

a Single-container inventories will not exceed $189 \mathrm{~L}$.

b Consists of perfluoro compounds (C5-18); actual composition is proprietary. The hazards associated with the vapors of fluorinert are low, but decomposition products, including hydrogen fluoride and perfluoroisobutylene (PFIB), may be produced at elevated temperatures $\left(>100^{\circ} \mathrm{C}\right.$ ). The threshold limit value (TLV) (ceiling) for PFIB is $0.082 \mathrm{mg} / \mathrm{m}^{3}$.

c In addition to fused silica, borosilicate and laser glass are used for optics components. They are not listed here because they are solids, and no release mechanism has been identified.

d Total quantity per beamline, consisting of $3.6-\mathrm{kg}$ debris shield, $15.3-\mathrm{kg}$ final focusing lens, two $10.9-\mathrm{kg}$ transfer spatial filter lenses, two $10.4-\mathrm{kg}$ cavity spatial filter lenses, $5.6-\mathrm{kg}$ gas box window, two $11.2-\mathrm{kg}$ switch windows, and $7.1-\mathrm{kg}$ deformable mirror.

e Total quantity per beamline.

f Ignitrons are high-current switches used to discharge energy storage capacitors, which are used to fire laser flashlamps.

g Single ignitron inventories are approximately $6.5 \mathrm{~kg}(0.47 \mathrm{~L})$.

h Polytetrafluoroethylene. Decomposition products, such as PFIB, may be formed at elevated temperatures $\left(>450^{\circ} \mathrm{C}\right)$.

i Tetraethylorthosilicate can potentially form silicon dioxide, which has a TLV of $2 \mathrm{mg} / \mathrm{m}^{3}$. 
TABLE 4.6 Estimated Chemical Inventories for the National Ignition Facility Enhanced Option

\begin{tabular}{|c|c|c|}
\hline Chemical & Source & Quantity \\
\hline Acetone & Solvent for cleaning & $38 \mathrm{~L}(30 \mathrm{~kg})$ \\
\hline $\begin{array}{l}\text { Alumina } \\
\text { (aluminum oxide) }\end{array}$ & Particulates from first wall & $29.6 \mathrm{~kg}$ \\
\hline $\begin{array}{l}\text { Ammonium hydroxide } \\
(50 \% \mathrm{wt})\end{array}$ & Optics treatment & $\begin{array}{l}38 \mathrm{~L} \text { ( } \sim 38 \mathrm{~kg} \text { ammonia- } \\
\text { equivalent) }\end{array}$ \\
\hline Copper & Particulates from cryostat & $<0.9 \mathrm{~kg}$ \\
\hline Ethanol & $\begin{array}{l}\text { Solvent for cleaning and } \\
\text { optics treatment }\end{array}$ & $1,514 \mathrm{~L}^{\mathrm{a}}(-1,200 \mathrm{~kg})$ \\
\hline Fluorinert $^{b}$ & Optics treatment & $151 \mathrm{~L}$ \\
\hline \multirow[t]{2}{*}{ Fused silica $^{c}$} & $\begin{array}{l}\text { Particulates from ablated } \\
\text { debris shield }\end{array}$ & $4.4 \mathrm{~kg}$ \\
\hline & $\begin{array}{l}\text { Lenses, windows, debris } \\
\text { shields, deformable mirrors }\end{array}$ & $96.5 \mathrm{~kg}^{\mathrm{d}}$ \\
\hline Gold & Particulates from hohlraum & $<1.7 \mathrm{~kg}$ \\
\hline Hafnium oxide & Optics coating & $0.07 \mathrm{~kg}^{\mathrm{e}}$ \\
\hline $\begin{array}{l}\text { Hydrofluoric acid } \\
(40 \text { gal at } 1 \% \text { wt, } \\
0.5 \text { gal at } 52 \% \text { wt) }\end{array}$ & Optics treatment & $\begin{array}{l}208 \mathrm{~L} \mathrm{(} 22 \mathrm{~kg} \text { hydrogen } \\
\text { fluoride) }\end{array}$ \\
\hline $\begin{array}{l}\text { KDP (potassium } \\
\text { dihydrogen phosphate) }\end{array}$ & $\begin{array}{l}\text { Frequency conversion } \\
\text { crystals }\end{array}$ & \\
\hline $\mathrm{KH}_{2} \mathrm{PO}_{4}$ & & $3.2 \mathrm{~kg}$ \\
\hline $\begin{array}{l}\mathrm{KD}_{1.2} \mathrm{H}_{0.8} \mathrm{PO}_{4} \\
\text { (deuterated) }\end{array}$ & & $7.6 \mathrm{~kg}$ \\
\hline Mercury & Ignitrons $^{f}$ & $450 \mathrm{~L}\left(\sim 6,200 \mathrm{~kg}^{\mathrm{g}}\right)$ \\
\hline
\end{tabular}


TABLE 4.6 (Cont.)

\begin{tabular}{lll}
\multicolumn{1}{c}{ Chemical } & \multicolumn{1}{c}{ Source } & \multicolumn{1}{c}{ Quantity } \\
\hline $\begin{array}{l}\text { Sodium hydroxide } \\
\text { (50 gal at } 3 \% \mathrm{wt}, \\
\begin{array}{l}\text { 20 gal at } 50 \% \mathrm{wt}, \text { or } \\
\text { solid pellets })\end{array}\end{array}$ & Cleaner for debris shields & $\begin{array}{l}265 \mathrm{~L}(\sim 8 \mathrm{~kg} \text { sodium } \\
\text { hydroxide })\end{array}$ \\
Stainless steel & $\begin{array}{l}\text { Particulates from target } \\
\text { positioner }\end{array}$ & $<0.6 \mathrm{~kg}$ \\
Teflon & Optics treatment & $3 \mathrm{~kg}$ \\
Tetraethylorthosilicate & Optics treatment & $379 \mathrm{~L}(353 \mathrm{~kg})$ \\
Zirconium oxide & Optics coating & $0.003 \mathrm{~kg}$ \\
\hline
\end{tabular}

a Single-container inventories will not exceed $189 \mathrm{~L}$.

b Consists of perfluoro compounds (C5-18); actual composition is proprietary. The hazards associated with the vapors of fluorinert are low, but decomposition products, including hydrogen fluoride and perfluoroisobutylene (PFIB), may be produced at elevated temperatures $\left(>100^{\circ} \mathrm{C}\right)$. The TLV (ceiling) for PFIB is $0.082 \mathrm{mg} / \mathrm{m}^{3}$.

c In addition to fused silica, borosilicate and laser glass are used for optics components. They are not listed here because they are solids, and no release mechanism has been identified.

d Total quantity per beamline, consists of $3.6-\mathrm{kg}$ debris shield, $15.3-\mathrm{kg}$ final focusing lens, two $10.9-\mathrm{kg}$ transfer spatial filter lenses, two $10.4-\mathrm{kg}$ cavity spatial filter lenses, $5.6-\mathrm{kg}$ gas box window, two $11.2-\mathrm{kg}$ switch windows, and $7.1-\mathrm{kg}$ deformable mirror.

e Total quantity per beamline.

f Ignitrons are high-current switches used to discharge energy storage capacitors, which are used to fire laser flashlamps.

g Single ignitron inventories are approximately $6.5 \mathrm{~kg}(0.47 \mathrm{~L})$.

h Polytetrafluoroethylene. Decomposition products, such as PFIB, may be formed at elevated temperatures $\left(>450^{\circ} \mathrm{C}\right)$.

i Tetraethylorthosilicate can potentially form silicon dioxide, which has a TLV of $2 \mathrm{mg} / \mathrm{m}^{3}$. 
TABLE 4.7 Summary of Chemical Accident Release Scenarios for the National Ignition Facility ${ }^{\mathrm{a}}$

\begin{tabular}{|c|c|c|c|c|c|}
\hline Release Scenario & $\begin{array}{l}\text { Vulnerable } \\
\text { Inventory } \\
(\mathrm{kg})\end{array}$ & $\begin{array}{l}\text { Release } \\
\text { Fraction }\end{array}$ & $\begin{array}{c}\text { Total } \\
\text { Quantity } \\
\text { Released (g) }\end{array}$ & $\begin{array}{l}\text { Release } \\
\text { Duration }\end{array}$ & $\begin{array}{c}\text { Release } \\
\text { Height }\end{array}$ \\
\hline \multicolumn{6}{|l|}{ Mercury } \\
\hline Equipment Failure & 6.5 & $1.0 \times 10^{-2}$ & 65 & $30 \mathrm{~min}$ & $17 \mathrm{~m}$ \\
\hline Aircraft Accident & 51.5 & 1.0 & 51,500 & $10 \mathrm{~min}$ & Ground level \\
\hline Alumina (earthquake) & $\begin{array}{r}6.7 \\
(29.6)\end{array}$ & $1.0 \times 10^{-3}$ & $\begin{array}{r}6.7 \\
(29.6)\end{array}$ & $7.6 \min ^{b}$ & Ground level \\
\hline Silica (earthquake) & $\begin{array}{c}2.1 \\
(4.4)\end{array}$ & $1.0 \times 10^{-3}$ & $\begin{array}{c}2.1 \\
(4.4)\end{array}$ & $7.6 \mathrm{~min}^{\mathrm{b}}$ & Ground level \\
\hline \multirow[t]{2}{*}{$\begin{array}{l}\text { Hydrogen fluoride } \\
\text { (overheating) }\end{array}$} & $\begin{array}{c}273 \\
\text { fluorinert } \\
(151 \mathrm{~L})\end{array}$ & $1.0 \times 10^{-4}$ & 27.3 & $1 \mathrm{~h}$ & Ground level \\
\hline & $3 \mathrm{~kg}$ Teflon & $3.8 \times 10^{-1}$ & 1,145 & & \\
\hline $\begin{array}{l}\text { Carbonyl fluoride } \\
\text { (overheating) }\end{array}$ & $3 \mathrm{~kg}$ Teflon & $6.3 \times 10^{-1}$ & 1,890 & $1 \mathrm{~h}$ & Ground level \\
\hline Propane $^{c}$ (leak) & $56,780 \mathrm{~L}$ & 1.0 & $56,780 \mathrm{~L}$ & $1 \mathrm{~h}$ & Ground level \\
\hline
\end{tabular}

a Values are the same for conceptual design and enhanced options except for vulnerable inventory and total quantity released for alumina and silica. Values in parentheses for those two materials are for the enhanced option.

b Corresponds to a wind speed of $1 \mathrm{~m} / \mathrm{s}$. See text for release durations corresponding to other wind speeds.

c Propane is present only at NTS. Modeling was not performed for propane at the other candidate sites.

\subsubsection{Mercury Release Scenarios and Results}

\subsubsection{Switch Rupture}

Mercury was identified as a concern because of its low threshold limit value of $0.025 \mathrm{mg} / \mathrm{m}^{3}$ (American Conference of Government Industrial Hygienists [ACGIH 1994]) and ceiling of $0.1 \mathrm{mg} / \mathrm{m}^{3}$ (Occupational Safety and Health Administration [OSHA]) (ACGIH 1994). It 
would be used in the ignitron switches ${ }^{1}$ in the capacitor bank bays of NIF. Approximately 200 switches would be used in the bays, and each would contain $0.473 \mathrm{~L}(0.125 \mathrm{gal})$ of mercury. Given the low toxic threshold for mercury, a single switch rupture would potentially present a chemical hazard. The Conceptual Design and Enhanced options have identical power supply requirements, so a mercury release resulting from equipment failure would be the same in either case.

This first accident scenario for a mercury release results from the failure of a water-cooled tube due to repeated electrical arcing with the eccentric anode. When this happened, water vapor might possibly fill the ignitron tube. The resulting pressurization could then produce a spray release of mercury. Such a failure is estimated to have a probable frequency of between $10^{-4}$ and $10^{-6}$ per year. A release fraction of $10^{-2}$ is estimated for the $0.473 \mathrm{~L}(0.125 \mathrm{gal})$ of mercury in the ignitron (Mishima 1993). This assumption yields a conservative estimate of 65 grams (2.29 oz) of mercury released over a period of 30 minutes; a longer release time would imply lower concentration levels of longer duration. The time period is chosen to be conservatively small since the ventilation rate is not known. The release mass includes vapor and droplets having diameters of $50 \mu \mathrm{m}$ or less.

The second accident scenario for a mercury release results from the crash of a light aircraft and the resulting fire. Such an accident at the NIF Laser and Target Area Building was found to be a credible event (Kimura 1996), with the capacitor bays being the primary area of concern for a mercury release. Most of the mass of an airplane is associated with the engine. Given that the engine of a light aircraft is much smaller than a single capacitor bay module, it was assumed that no more than two equivalent capacitor bay modules would be damaged under this accident scenario. Each capacitor bay module contains 20 capacitors and 4 switches; therefore, a total of 40 capacitors and 8 switches are assumed to be severely damaged as a result of the accident and associated fire. The vulnerable inventory of mercury is $51.5 \mathrm{~kg}$. The total energy available from the resulting fire was determined to be sufficient to release the entire inventory of mercury over a 10-minute fire duration.

The threshold limit value, time-weighted averages (TLV-TWAs) for hazardous chemicals are typically used by the ACGIH as limits for repeated exposure over time, such as a 40-hour work week over many years. The limits are overly conservative in the context of a single event, such as the accident scenarios analyzed here for NIF. Exposure criteria for chemicals such as mercury are set low for repeated exposure because of the high toxicities. Mercury tends to accumulate in the human body, so any permissible long-term exposure must be low. Since the accident for NIF is assumed to occur only once (leading to a single acute impact), the TLV-TWA was multiplied by five to arrive at an effective Emergency Response Planning Guideline-2 (ERPG-2) (American Industrial Hygiene Association 1988) exposure criterion of $0.125 \mathrm{mg} / \mathrm{m}^{3}$.

Five of the six accident scenario analyses were carried out with the ALOHA model (Reynolds 1992), a model that is commonly used for emergency response planning. The sixth accident scenario, the aircraft accident and resulting fire, was modeled with the FIREPLUME model

1 Ignitron switches are high-current switches used to discharge energy storage capacitors, which are used to fire laser flashlamps. 
(Brown 1996). The ALOHA model uses several source models to compute the release rate as a function of time. It then uses either a neutrally buoyant or heavy gas model to treat downwind dispersion. Finally, it predicts the edge of the hazard zone of the plume on the basis of health criteria values used as input to the model as appropriate for the chemical or chemicals emitted.

Like the ALOHA model, the FIREPLUME model consists of two components. The first component is a Monte Carlo model that estimates the dispersion of both buoyant and nonbuoyant chemical releases in the atmospheric boundary layer. The second component is a puff dispersion model that is based in part on a Monte Carlo model. The FIREPLUME model is used to predict ground-level concentrations resulting from the release of a hazardous material within an instantaneously discharged thermal (i.e., a fireball), a fire, or a smoldering fire before it is fully extinguished.

The health criteria used in this study is the ERPG-2 or its surrogate if an ERPG-2 value has not yet been determined. The ERPG-2 refers to the maximum airborne concentration below which it is believed that nearly all individuals could be exposed for up to 1 hour without developing irreversible or other serious health effects or symptoms that could impair their abilities to take protective action. Individuals who experience higher concentrations than those limits generally suffer respiratory distress of various kinds.

The equipment failure accident scenario for mercury was simulated with the ALOHA model for each of the five candidate sites. ALOHA defaulted to the heavy gas model by virtue of the molecular weight of mercury. The manual override feature was used to select the neutrally buoyant model to determine which of the two model options was most conservative. Although the source elevation was taken at $17 \mathrm{~m}(56 \mathrm{ft})$ above ground level for the mercury release, the heavy gas model defaults to ground level. Probably for this reason, the heavy gas model produced the more conservative results. Table 4.8 summarizes the results.

Except for the NLVF site, no point of public access is threatened in the mercury scenario. The concern would be for workers in the immediate vicinity of the spill who are either outdoors or in the NIF area when the release occurred. The indoor concentrations predicted by ALOHA depend on the specific building ventilation. Details of each building within each threat zone would be necessary for quantitative evaluation. Typically, single-storied structures show concentrations of a factor of five or more below the outdoor levels. At the NLVF, the predicted maximum threat zone extends just slightly to the edge of public access.

The situation at LLNL warrants careful study because a veterinary hospital located across Greenville Road east-northeast of the proposed NIF location was identified as a sensitive location. The hospital is the nearest point of public access to NIF. In the mercury release scenario, the source would be in the capacitor switchbank about $245 \mathrm{~m}(804 \mathrm{ft})$ from the hospital. Predicted mercury concentrations just fall just within the level of concern at that location. 
TABLE 4.8 Summary of Mercury Release Scenario Predictions at the Five National Ignition Facility Candidate Sites ${ }^{\mathbf{a}}$

\begin{tabular}{llllc}
\hline \multicolumn{1}{c}{ Site } & \multicolumn{1}{c}{$\begin{array}{c}\text { Nearest } \\
\text { Public Access }\end{array}$} & $\begin{array}{c}\text { Dispersion } \\
\text { Type }^{\mathrm{b}}\end{array}$ & $\begin{array}{c}\text { Outdoor/Indoor } \\
\text { Concentration } \\
\left(\mathrm{mg} / \mathrm{m}^{3}\right)\end{array}$ & $\begin{array}{c}\text { Maximum } \\
\text { Threat Zone } \\
(\mathrm{m})\end{array}$ \\
\hline LLNL & $245 \mathrm{~m} \mathrm{ENE}$ & Heavy gas & $0.124 / 0.025$ & 237 \\
NTS & $20,000 \mathrm{~m} \mathrm{SSW}$ & Heavy gas & Negligible & 237 \\
NLVF & $210 \mathrm{~m} \mathrm{~W}$ & Heavy gas & $0.165 / 0.033$ & 239 \\
LANL & $1,620 \mathrm{~m} \mathrm{NNE}$ & Heavy gas & Negligible & 237 \\
SNL & $1,864 \mathrm{~m} \mathrm{~N}$ & Heavy gas & $0.0204 / 0.0035$ & 237 \\
\hline
\end{tabular}

a Results are the same for the Conceptual Design and Enhanced options.

b The ALOHA model chooses either a neutrally buoyant or a heavy gas treatment for dispersion, depending on which approach is most appropriate.

c Predicted concentrations at nearest point of public access.

Although the mercury scenario would pose no concern to the public at LLNL, personnel within NIF and immediately outside could be affected. Here again, the only potential hazard would be to workers in the immediate location of the spill and those outdoors within the maximum threat zone who are otherwise unprotected. Inside neighboring trailers 5993, 5984, 5985, and 5927, the concentrations would probably remain below the level of concern, depending upon the building ventilation.

Table 4.8 presents the results of the modeling for the mercury release resulting from an aircraft accident and associated fire scenario at each of the five NIF candidate sites. Outdoor concentrations of mercury are predicted with the FIREPLUME model. Model results indicate negligible mercury concentrations for all distances from the site of the aircraft accident and associated fire. Predicted concentrations of mercury are significantly less than its ERPG-2 value, $0.125 \mathrm{mg} / \mathrm{m}^{3}$.

\subsubsection{Aircraft Crash}

The occurrence of a light aircraft crash at the NIF location is a credible event (Kimura 1996). The probability of such an event is approximately $4 \times 10^{-5} /$ year. The capacitor bays are an area of specific concern because impact to the ignitron switches could result in the release of mercury. Given that an aircraft engine is much smaller than a single capacitor bay module, it is estimated that no more than the equivalent of two capacitor modules (i.e., 40 capacitors and 
8 switches) would be damaged by the incoming aircraft (LLNL 1996). Because the capacitors contain dielectric fluid, which is combustible, it is assumed that the spilled material would become involved in a fire resulting from ignition of spilled aircraft fuel. The temperature of the fire is expected to be in excess of the boiling point of mercury $\left(356^{\circ} \mathrm{C}\right)$, thus a substantial amount of mercury vapor would be generated.

Modeling of this accident scenario was conducted at LLNL using the ALOHA model with values determined for the plume rise, effective release height, and the source term (LLNL 1996). The modeling results indicate a maximum off-site mercury concentration of $0.16 \mathrm{mg} / \mathrm{m}^{3}$ $\left(7.4 \times 10^{-6} \mathrm{oz} / \mathrm{yd}^{3}\right)$ at a distance of $4.2 \mathrm{~km}(2.6 \mathrm{mi})$ downwind. Although the concentration calculated at this location exceeds the ERPG-2-equivalent, the total mercury exposure from this event is calculated to be less than that corresponding to the ERPG-2-equivalent value because this condition would exist for only 10 minutes. Consequently, no human health effects are predicted in terms of the ERPG-2 emergency response metric.

Additional modeling of this accident scenario was conducted with the FIREPLUME model (Brown et al. 1996). The FIREPLUME model consists of two components. The first component is a Monte Carlo model used to estimate the dispersion of both buoyant and non-buoyant chemical releases in the atmospheric boundary layer. The second component is a puff dispersion model based in part on a Monte Carlo model. The FIREPLUME model is used to predict the ground-level concentration resulting from the release of a hazardous material within an instantaneously discharged thermal event (a fireball), a fire, or a smoldering fire before it is fully extinguished.

For the small aircraft crash accident scenario, the assumption was made that the volatile portion of the aircraft fuel and the capacitor dielectric fluid was consumed during the fire, and that no volatile component remained at the start of the cooldown period. Values used for the effective diameter of the burning surface, the temperature of the fire, and meteorological conditions were based on the methodology previously discussed. Modeling was completed for stability classes A, $\mathrm{D}$, and $\mathrm{F}$.

On the basis of FIREPLUME modeling results, the maximum off-site consequence for this accident scenario is below the ERPG-2-equivalent for mercury (i.e., below $0.25 \mathrm{mg} / \mathrm{m}^{3}[1.16 \times$

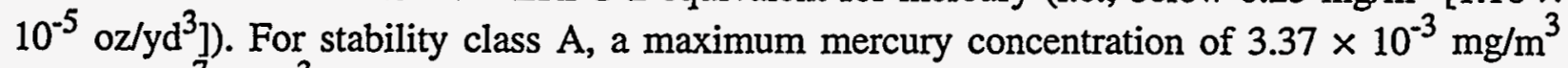
$\left(1.56 \times 10^{-7} \mathrm{oz} / \mathrm{yd}^{3}\right)$ was predicted at a distance of $11,600 \mathrm{~m}(38,058 \mathrm{ft})$. For D class stability, a maximum mercury concentration of $1.87 \times 10^{-4} \mathrm{mg} / \mathrm{m}^{3}\left(8.68 \times 10^{-9} \mathrm{oz} / \mathrm{yd}^{3}\right)$ was predicted at a distance of $80,000 \mathrm{~m}(262,467 \mathrm{ft})$. No impacts above ERPG-2 threshold levels occurred for F stability computer runs as well. The FIREPLUME model results support the LLNL modeling results of this accident scenario. Therefore, the small aircraft crash accident scenario would not represent a threat to the general public from plume rise and dispersion effects. Should the assumption that there be no volatile component at the start of the cooldown period prove to be incorrect, then the FIREPLUME modeling results would change. Additional modeling with the FIREPLUME 
model would be required because impacts at the ground from the cooldown period releases could lead to concentrations above threshold.

\subsubsection{Alumina and Silica Release Scenarios and Results}

Alumina and silica particulates were identified as a potential health concern for the second accident scenario. These materials are not normally considered hazardous for short-term exposure; the concern would be accumulation of dust in the lungs after repeated exposure. The TLV-TWA for alumina is $10 \mathrm{mg} / \mathrm{m}^{3}$ (ACGIH). For silica, the TLV-TWA is $0.1 \mathrm{mg} / \mathrm{m}^{3}$. The single-event exposure criterion was obtained by multiplying these values by a factor of 5 to obtain an effective ERPG-2.

The alumina/silica accident scenario involves particulates that would be released as a result of an earthquake. The scenario considered a severe earthquake. Although the target chamber is not expected to fail, failure of the beam tubes would expose the chamber to airflow. In that event, alumina, silica, and other particulate matter in the chamber could be blown out of the target area and dispersed into the environment. The timing of an earthquake must be considered, because the amounts of particulates present would be a function of facility operation. The event is assumed to occur after the last experiment of the year; more specifically, when the buildup had resided in the chamber for one week after the last experiment. The joint frequency of these combined events is estimated to be $1 \times 10^{-8}$ per year for the Conceptual Design Option, and $2 \times 10^{-8}$ per year for the Enhanced Option.

Alumina particulates would be created from ablation of first wall material. The amount of particulate matter in the chamber would depend on the experiment accumulation and cleanup frequency. These factors cannot be known with certainty at present, but a conservative estimate of $6.7 \mathrm{~kg}(14.8 \mathrm{lb})$ for the Conceptual Design Option and $29.6 \mathrm{~kg}(65.3 \mathrm{lb})$ for the Enhanced Option can be derived on the basis of the total accumulation over one full year. The silica particulates would be created from ablated debris shield material. The vulnerable inventory is estimated to be $2.1 \mathrm{~kg}$ $(4.6 \mathrm{lb})$. Under the earthquake accident scenario, the alumina and silica particulates would be released together in a combined mixture.

The exit outflow area was estimated for the collapse of 24 beam tubes and the switchyard, yielding $40.8 \mathrm{~m}^{2}\left(439 \mathrm{ft}^{2}\right)$. A conservative mass fraction of $10^{-3}$ was used for the amount actually removed by the outflow (DOE 1992). This fraction implies a release of $6.7 \mathrm{~g}(0.24 \mathrm{oz})$ of alumina and $2.1 \mathrm{~g}(0.07 \mathrm{oz})$ of silica in 7.6 minutes for the Conceptual Design Option and $29.6 \mathrm{~g}(1.04 \mathrm{oz})$ of alumina and $4.4 \mathrm{~g}(0.16 \mathrm{oz})$ of silica for the Enhanced Option.

Release durations were computed from the volumetric displacement for a given wind speed, with adjustment for mixing. With a $1-\mathrm{m} / \mathrm{s}(3.3-\mathrm{ft} / \mathrm{s})$ wind, the computed duration is 7.6 minutes for both the Conceptual Design and Enhanced options. The most conservative source height, ground 
level, was assumed. These conditions were modeled as an instantaneous release with the ALOHA code, which yielded higher peak concentrations and is therefore conservative. Since both compounds would be released simultaneously and their biological effects are similar, their toxicities must be weighted additively for this scenario.

The dispersion of the airborne particulates would depend upon wind and atmospheric stability. Higher wind speeds cause greater dispersion because of increased turbulence, but the rate of release also increases accordingly. The duration of the release, therefore, decreases as wind speed increases. These competing factors tend to offset each other, making wind speed less critical than atmospheric stability. All other factors being equal, the largest particulate concentrations would occur under the most stable atmospheric conditions, as characterized by class $\mathrm{F}$ stability. Therefore, a wind speed of $1.0 \mathrm{~m} / \mathrm{s}(3.3 \mathrm{ft} / \mathrm{s})$ with class $F$ stability was proposed as a conservative concentration scenario.

For LLNL, the alumina/silica release from the target chamber was modeled by taking the source to be $400 \mathrm{~m}$ ( $1,312 \mathrm{ft}$ ) from the veterinary hospital. Predictions indicate no impact to the public at any site. The only potential hazard would be to workers in the immediate location of the release and people outdoors within the maximum threat zone who are otherwise unprotected. Inside neighboring trailers $5983,5984,5985$, and 5927 , the concentrations would probably remain below the level of concern, depending upon the building ventilation. Indoor concentrations were computed for a single-story building in the model scenario. Table 4.9 summarizes the predictions for the alumina/silica release scenarios for the Conceptual Design and Enhanced options at the five candidate sites.

\subsubsection{Carbonyl Fluoride and Hydrogen Fluoride Release Scenarios and Results}

Optical maintenance operations involve the use of Teflon ${ }^{\circledR}$ dissolved in a fluorinert solution to treat optics. Hydrogen fluoride and carbonyl fluoride can be released if these materials are heated sufficiently. Hydrogen fluoride can pose a hazard because it is acidic and can cause severe burns to eyes and internal tissue and can cause kidney or liver damage. The worst case would be for a heat source to decompose the Teflon. The fourth and fifth release accident scenarios can then be postulated for these two fluoride compounds. The $3.0 \mathrm{~kg}(6.6 \mathrm{lb})$ of Teflon in the inventory could potentially give a fractional carbonyl fluoride release of 0.63 , resulting in a release of $1,890 \mathrm{~g}$ ( $66.7 \mathrm{oz}$ ) for the fifth accident scenario. The ERPG-2 for carbonyl fluoride is $27.5 \mathrm{mg} / \mathrm{m}^{3}$.

ALOHA selected the heavy gas model for these calculations. The Conceptual Design and Enhanced options are the same for this chemical. For LLNL, the release was modeled as a continuous source at Building B392, $120 \mathrm{~m}$ (394 ft) from the veterinary hospital. The predicted 
TABLE 4.9 Summary of Alumina/Silicate Release Scenario Predictions at the Five National Ignition Facility Candidate Sites for Conceptual Design and Enhanced Options

\begin{tabular}{lllll}
\hline \multicolumn{1}{c}{ Site } & \multicolumn{1}{c}{$\begin{array}{c}\text { Nearest } \\
\text { Public Access }\end{array}$} & \multicolumn{1}{c}{ Dispersion Type $^{\mathrm{a}}$} & $\begin{array}{c}\text { Outdoor/Indoor } \\
\text { Concentration } \\
\left(\mathrm{mg} / \mathrm{m}^{3}\right)\end{array}$ & $\begin{array}{c}\text { Maximum } \\
\text { Threat Zone } \\
(\mathrm{m})\end{array}$ \\
\hline Conceptual & Design Option & & & \\
LLNL & $800 \mathrm{~m} \mathrm{E}$ & Neutrally buoyant & $0.0509 / 0.0001$ & 171 \\
NTS & $20,000 \mathrm{~m} \mathrm{SSW}$ & Neutrally buoyant & Negligible & 171 \\
NLVF & $210 \mathrm{~m} \mathrm{~W}$ & Neutrally buoyant & $0.296 / 0.002$ & 171 \\
LANL & $1,620 \mathrm{~m} \mathrm{NNE}$ & Neutrally buoyant & Negligible & 171 \\
SNL & $1,864 \mathrm{~m} \mathrm{~N}$ & Neutrally buoyant & $0.0123 / 0.0001$ & 174 \\
& & & & \\
Enhanced & Option & & & 231 \\
LLNL & $800 \mathrm{~m} \mathrm{E}$ & Neutrally buoyant & $0.11 / 0.0017$ & 231 \\
NTS & $20,000 \mathrm{~m} \mathrm{SSW}$ & Neutrally buoyant & Negligible & 231 \\
NLVF & $210 \mathrm{~m} \mathrm{~W}$ & Neutrally buoyant & Negligible & 231 \\
LANL & $1,620 \mathrm{~m} \mathrm{NNE}$ & Neutrally buoyant & Negligible & \\
SNL & $1,864 \mathrm{~m} \mathrm{~N}$ & Neutrally buoyant & $0.0268 / 0.0001$ & 234 \\
\hline
\end{tabular}

a The ALOHA model chooses either a neutrally buoyant or heavy gas treatment for dispersion, depending on which approach is most appropriate.

b Predicted concentrations at nearest point of public access.

c Differences in predictions among the various sites $(171 \mathrm{~m}$ vs. $174 \mathrm{~m}$ or $231 \mathrm{~m}$ vs. 234 $\mathrm{m})$ are not important and are due to the atmospheric differences (elevation) among the sites.

d The maximum threat zone corresponds to the distance from the source beyond which outdoor concentrations are below the ERPG-2 value.

maximum threat zone was $99 \mathrm{~m}$ ( $325 \mathrm{ft}$ ); therefore, the concentrations would pose no immediate threat to the public. As in the other analyses, personnel in the immediate vicinity could be adversely affected at each site (Table 4.10).

It is also possible that the carbonyl fluoride could react to form hydrogen fluoride (Table 4.11). The estimated release fraction for such a reaction is $0: 38$, corresponding to $1,145 \mathrm{~g}$ ( $40.4 \mathrm{oz}$ ) of hydrogen fluoride released in the fourth accident scenario. This amount would be added to the $27.3 \mathrm{~g} \mathrm{(1.0} \mathrm{oz)} \mathrm{released} \mathrm{directly} \mathrm{from} \mathrm{the} \mathrm{fluorinert} \mathrm{solution,} \mathrm{making} \mathrm{a} \mathrm{total} \mathrm{of} 1,172.3 \mathrm{~g}$ ( $41.4 \mathrm{oz}$ ) of hydrogen fluoride. The ERPG-2 for hydrogen fluoride is $16.4 \mathrm{mg} / \mathrm{m}^{3}$. The releases for the fourth and fifth scenarios are both likely to continue over a period of one hour. 
TABLE 4.10 Summary of Carbonyl Fluoride Release Scenario Predictions at the Five National Ignition Facility Candidate Sites for Conceptual Design and Enhanced Options ${ }^{\text {a }}$

\begin{tabular}{llllc}
\hline Site & \multicolumn{1}{c}{$\begin{array}{c}\text { Nearest } \\
\text { Public Access }\end{array}$} & $\begin{array}{c}\text { Dispersion } \\
\text { Type }^{\mathrm{b}}\end{array}$ & $\begin{array}{c}\text { Outdoor/Indoor } \\
\text { Concentration } \\
\left(\mathrm{mg} / \mathrm{m}^{3}\right)\end{array}$ & $\begin{array}{c}\text { Maximum } \\
\text { Threat Zone } \\
(\mathrm{m})\end{array}$ \\
\hline LLNL & $120 \mathrm{~m} \mathrm{ENE}$ & Heavy gas & $18.9 / 4.14$ & 99 \\
NTS & $20,000 \mathrm{~m} \mathrm{SSW}$ & Heavy gas & Negligible & -75 \\
NLVF & $210 \mathrm{~m} \mathrm{~W}$ & Heavy gas & $4.83 / 1.02$ & 75 \\
LANL & $1,620 \mathrm{~m} \mathrm{NNE}$ & Heavy gas & $0.198 / 0.0324$ & 70 \\
SNL & $1,864 \mathrm{~m} \mathrm{~N}$ & Heavy gas & $0.608 / 0.114$ & 70 \\
\hline
\end{tabular}

a Conceptual Design and Enhanced options have the identical accidents proposed, so no differences exist between these options.

b The ALOHA model chooses either a neutrally buoyant or heavy gas treatment for dispersion, depending on which approach is most appropriate.

c Predicted concentrations at nearest point of public access.

d The maximum threat zone corresponds to the distance from the source beyond which outdoor concentrations are below the ERPG-2 value.

The carbonyl fluoride and hydrogen fluoride releases are considered at LLNL because of optics maintenance in three buildings, B391, B392, and B321. For these two scenarios, the nearest point of public access would be the industrial park to the east. For both the carbonyl and hydrogen fluoride scenarios, the nearest potential source to the industrial park would be Building B392, which is $120 \mathrm{~m}(394 \mathrm{ft})$ away.

\subsubsection{Propane Gas Release Scenario and Results}

The sixth accident scenario considered (for NTS only) was a propane gas leak from the storage tanks at NTS. Four large tanks are present at NTS, and the two largest ones, which hold $28,390 \mathrm{~L}$ (7,500 gal) of propane each, are positioned side by side. The worst-case scenario assumes that both tanks simultaneously leak from a 5.08-cm (2.0-in.) diameter hole located $0.3 \mathrm{~m}$ (1.0 ft) from the bottom of the tank as a continuous release over one hour. The level (concentration) of concern is the estimated ERPG-2, again taken to be five times the OSHA permissible exposure limit of $1,800 \mathrm{mg} / \mathrm{m}^{3}$, giving a level of concern of $9,000 \mathrm{mg} / \mathrm{m}^{3}$. This concentration would occur out to a distance of $755 \mathrm{~m}(2,477 \mathrm{ft})$ from the source, and this area would constitute the maximum threat zone. 
TABLE 4.11 Summary of Hydrogen Fluoride Release Scenario Predictions at the Five National Ignition Facility Candidate Sites for Conceptual Design and Enhanced Options $^{\mathrm{a}}$

\begin{tabular}{llllc}
\hline \multicolumn{1}{c}{ Site } & \multicolumn{1}{c}{$\begin{array}{c}\text { Nearest } \\
\text { Public Access }\end{array}$} & Dispersion Type ${ }^{\mathrm{b}}$ & $\begin{array}{c}\text { Outdoor/Indoor } \\
\text { Concentration } \\
\left(\mathrm{mg} / \mathrm{m}^{3}\right)\end{array}$ & $\begin{array}{c}\text { Maximum } \\
\text { Threat Zone }^{\mathrm{d}} \\
(\mathrm{m})\end{array}$ \\
\hline LLNL & $120 \mathrm{~m} \mathrm{ENE}$ & Neutrally buoyant & $11.2 / 4.66$ & 99 \\
NTS & $20,000 \mathrm{~m} \mathrm{SSW}$ & Neutrally buoyant & $<10^{-2} / 10^{-2}$ & 75 \\
NLVF & $210 \mathrm{~m} \mathrm{~W}$ & Neutrally buoyant & $3.78 / 1.54$ & 75 \\
LANL & $1,620 \mathrm{~m} \mathrm{NNE}$ & Neutrally buoyant & $0.005 / 0.077$ & 70 \\
SNL & $1,864 \mathrm{~m} \mathrm{~N}$ & Neutrally buoyant & $0.076 / 0.020$ & 70 \\
\hline
\end{tabular}

a Conceptual Design and Enhanced options have the identical accidents proposed, so no differences exist between these options.

b The ALOHA chooses either a neutrally buoyant or heavy gas treatment for dispersion, depending on which approach is most appropriate.

c Predicted concentrations at nearest point of public access.

d The maximum threat zone corresponds to the distance from the source beyond which outdoor concentrations are below the ERPG-2 value.

\subsection{TRANSPORTATION IMPACT ASSESSMENT}

Transportation impacts for both radiological and nonradiological causes resulting from the shipment of cryogenic tritium-filled targets were calculated from each of the tritium target manufacturing facilities to each of the candidate NIF locations. For each candidate location, five target manufacturing sites were assumed: the University of Rochester Laboratory of Laser Energetics (New York), LANL, General Atomics (San Diego, California), the Savannah River Site (South Carolina), and LLNL. For the transportation analysis, each of the manufacturing sites was assumed to ship $100 \%$ of the yearly supply of tritium to each of the five candidate NIF sites, although in practice the cryogenic tritium-filled targets might be shipped from several manufacturing sites.

Potential radiological (cargo-related) risks involved in the transportation of tritium targets would result from a release of tritium to the environment following a transportation accident sufficiently severe to breach the transportation package. Because tritium is a low-energy beta emitter with no associated gamma radiation, no radiological risks would result from routine (incident-free) transportation operations. 
Nonradiological (vehicle-related) risks were calculated for both routine and accident conditions. Nonradiological risks result from potential exposure to increased vehicular exhaust emissions in urban areas. Nonradiological accident risks result in fatalities from the physical trauma of a transportation accident and are independent of the cargo being transported.

For the Conceptual Design Option, risks resulting from transportation operations were estimated for two separate cases to establish the bounding impacts (Tobin and Brereton 1995). Case 1 involved 145 tritium shipments per year of $1.5 \mathrm{Ci}$ each, while case 2 involved 29 shipments per year of 7.5 $\mathrm{Ci}$ each. Because each of the two cases for the Conceptual Design Option would result in the same amount of tritium being shipped annually, the radiological risks associated with the shipment of cryogenic tritium targets would be identical. However, the nonradiological risks would be proportional to the distance of shipment; therefore, case 1 would yield the largest nonradiological risks. Also, single-accident consequences would be proportional to the amount of tritium shipped; therefore, the maximum consequence accident impacts would be larger in case 2 .

For the Enhanced Option, risks resulting from transportation operations were again estimated for two separate cases. Case 1 involved 335 tritium shipments per year, 90 of which would contain one direct-drive target of $15 \mathrm{Ci}$, while the remaining 245 shipments would each have a single indirect-drive target of $1.5 \mathrm{Ci}$. Case 2 involved shipping 5 targets per shipment or 67 shipments per year, 18 shipments with $75 \mathrm{Ci}$ of target material and 49 shipments with $7.5 \mathrm{Ci}$ of target material. Because each of the two cases for the Enhanced Option would result in the same amount of tritium being shipped annually, the radiological risks associated with the shipment of cryogenic tritium targets would be identical. However, the nonradiological risks would be proportional to the distance of shipment; therefore, case 1 would yield the largest nonradiological risks. Also, single-accident consequences would be proportional to the amount of tritium shipped; therefore, maximum consequence accident impacts would be larger in case 2 .

Transportation impacts were estimated for ground transport from the manufacturing site to the nearest major airport, air transport to the nearest major airport to the NIF site, and ground transport from the airport to the NIF site. ${ }^{2}$ For cases when the source was manufactured at the NIF site, any intrasite transfers were considered to be insignificant compared with the off-site transport because of the short distances involved.

2 Ground transport was assumed between LANL and SNL. 


\subsubsection{Methods}

\subsubsection{Transportation Routes}

Truck routes from each of the tritium target manufacturing facilities to the nearest major airport were calculated with the HIGHWAY 3.1 computer code (Johnson et al. 1993). HIGHWAY 3.1 was also used to calculate truck routes between each candidate NIF location and the nearest major airport. Distances between the major airports were calculated with an arc distance formula using the latitude and longitude coordinates of the airports.

\subsubsection{Routine Transportation Risk}

Tritium is a pure beta emitter with no associated gamma rays and is transported in a container that does not release tritium to the environment under incident-free (normal) conditions. Therefore, no radiological risks would be associated with routine transportation operations involving tritium targets.

Nonradiological risks associated with vehicular exhaust emissions were calculated for ground transportation operations. A risk factor generated by Rao et al. (1982) for latent mortality from pollution inhalation is $1 \times 10^{-7} / \mathrm{km}\left(1.6 \times 10^{-7} / \mathrm{mi}\right)$ for truck travel in an urban area. This risk factor is based on regression analysis of the effect on mortality from sulfur dioxide and particulate releases from diesel exhaust. Excess latent mortality is assumed to be equivalent to cancer fatalities. Nonradiological risks from routine transportation operations were calculated by multiplying the total distance of truck travel in urban areas by the risk factor. Similar risk factors are not available for rural and suburban areas.

\subsubsection{Transportation Accident Risk}

Transportation accident risk assessment is treated probabilistically in RADTRAN 4 (Neuhauser and Kanipe 1993) because accident occurrences are statistical. The accident risk is defined as the product of the accident consequence (dose) and the probability of the accident's occurring. In this respect, the RADTRAN 4 computer code estimates the collective accident risk to populations by considering a wide range of possible accidents, including low-probability, highconsequence and high-probability, low-consequence accidents.

For accidents that involve a release of radioactive material into the environment, RADTRAN 4 assumes that the material is dispersed according to standard Gaussian diffusion 
models. Default data for atmospheric dispersion were used in this analysis to represent an instantaneous ground-level release and a small-diameter source cloud (Neuhauser and Kanipe 1993).

As a complement to the RADTRAN risk calculations, the RISKIND computer code (Yuan et al. 1993) was used to estimate scenario-specific doses to MEIs and the collective population under accident conditions. The RISKIND calculations were conducted to supplement the results for collective risk calculated with RADTRAN 4. While the results for collective risk provide a measure of the overall risks of each case, the RISKIND calculations are meant to address areas of specific concern to individuals and subgroups of population.

The RISKIND accident consequence assessment for the NIF analysis focused on accidents that would result in the largest releases of radioactive material into the environment. For each scenario, accident consequences were calculated for a shipment of tritium targets that represented the highest potential radiological risk if an accident occurred. This worst-case accident assumed a complete release of the tritium cargo into the environment.

Nonradiological risks from transportation activities would result from the physical trauma of the accident itself. Nonradiological risks were calculated for round-trip shipping distances and only for the ground transport of the tritium targets. State-specific fatality rates were used for both urban and rural travel (Saricks and Kvitek 1994); urban fatality rates were conservatively assigned for suburban travel.

\subsubsection{Model Input}

\subsubsection{Source Terms and Shipment Configuration}

The radioactive source terms used for the transportation risk and consequence assessment were assumed to be cryogenic tritium-filled targets. The Conceptual Design Option assumes a total of $220 \mathrm{Ci}$ of tritium would be shipped from the target manufacturing facilities to NIF each year. The Enhanced Option increases tritium shipments to $1,720 \mathrm{Ci}$ of tritium per year. Tritium is a low-energy beta emitter with no associated gamma ray emission and has a 12.3-year half-life. For assessment purposes, released tritium was conservatively assumed to be in the oxide form (tritiated water). Because of biological uptake, tritium in this form is 10,000 times more hazardous than in its form in the targets. Conversion to the oxide form is expected only for a portion of the tritium as a result of fire following an accident. However, fire would be associated only with a small percentage of accidents.

The cryogenic tritium-filled targets for NIF were assumed to be transported in Type A packaging in accordance with 49 CFR Part 173. Type A packaging must withstand the conditions 
of normal transportation without loss or dispersal of the radioactive contents. ("Normal" transportation refers to all transportation conditions except those resulting from accidents or sabotage.) The Type A packaging would be required only if the curie content was greater than $20 \mathrm{Ci}$. A NIF tritium target would contain a maximum of $15 \mathrm{Ci}$ of tritium.

\subsubsection{Accident Severity Categories}

Methodology developed by the U.S. Nuclear Regulatory Commission (NRC) was used to characterize the potential severity of transportation-related accidents (NRC 1977). This method divides the range of transportation accidents into eight categories of progressive severity. Severity is described as a function of the magnitude of the mechanical forces (impact) and thermal forces (fire) to which a package may be subjected during an accident. The severity category assigned to an accident is independent of the specific accident sequence.

The accident classification scheme is designed to take into account all credible accidents, from low-probability, high-consequence events to high-probability, low-consequence events. A conditional probability of occurrence is assigned to each severity category using information from NUREG-0170 (NRC 1977). These probabilities are presented by population density zones in Table 4.12. Category I accidents are the least severe but most frequent, while Category VIII accidents are very severe but infrequent. To determine the expected frequency of an accident of a given severity, the conditional probability in the category is multiplied by the baseline accident rate. Although only one baseline accident rate is used for air transport (NRC 1977), truck shipments of radioactive materials are assigned different baseline accident rates for each population density zone for every state (Saricks and Kvitek 1994).

\subsubsection{Release Fractions}

Radiological risks are calculated by assigning package release fractions to each accident severity category using values from NUREG-0170 (NRC 1977). Release fractions vary according to the package type and the physical form of the material being transported and take into account all mechanisms necessary to create release of radioactive material from a damaged package to the environment.

Package release fractions for accidents of each severity category for type A packages are given in Table 4.13. The values for release fractions were obtained from NUREG-0170 (NRC 1977). Tritium remains in elemental form unless subject to fire or excessive heat. For all transportation accidents that result in a release of tritium into the environment, it is conservatively assumed that the tritium inside the targets would be completely oxidized into tritium water vapor at the moment of release. The aerosolized fraction (required for code input) can be directly related to the fraction 
TABLE 4.12 Conditional Probabilities of Transportation Accidents by Severity Category and Population Density Zone

Probability by Population Density Zone

\begin{tabular}{lllll} 
& & & & \\
\cline { 3 - 4 } Severity & Conditional & & & \\
Category & Probability $^{\mathrm{a}}$ & Rural & Suburban & Urban \\
\hline
\end{tabular}

Truck

$\begin{array}{ccccc}\text { I } & 0.55 & 0.1 & 0.1 & 0.8 \\ \text { II } & 0.36 & 0.1 & 0.1 & 0.8 \\ \text { III } & 0.07 & 0.3 & 0.4 & 0.3 \\ \text { IV } & 0.016 & 0.3 & 0.4 & 0.3 \\ \text { V } & 0.0028 & 0.5 & 0.3 & 0.2 \\ \text { VI } & 0.0011 & 0.7 & 0.2 & 0.1 \\ \text { VII } & 8.5 \times 10^{-5} & 0.8 & 0.1 & 0.1 \\ \text { VIII } & 1.5 \times 10^{-5} & 0.9 & 0.05 & 0.05\end{array}$

\begin{tabular}{ccccc} 
Aircraft & & & & \\
I & 0.57 & 0.05 & 0.9 & 0.05 \\
II & 0.16 & 0.05 & 0.9 & 0.05 \\
III & 0.09 & 0.1 & 0.8 & 0.1 \\
IV & 0.05 & 0.1 & 0.8 & 0.1 \\
V & 0.03 & 0.3 & 0.6 & 0.1 \\
VI & 0.03 & 0.3 & 0.6 & 0.1 \\
VII & 0.04 & 0.98 & 0.01 & 0.01 \\
VIII & 0.03 & 0.98 & 0.01 & 0.01 \\
\hline
\end{tabular}

a The conditional probability is defined as the probability that an accident is of a given severity given that an accident has occurred. Severity increases from Category I to Category VIII.

Source: NRC (1977). 
TABLE 4.13 Release, Aerosolized, and

Respirable Fractions for Type A Packages

Filled with Tritium Targets

\begin{tabular}{cccc}
\hline $\begin{array}{c}\text { Severity } \\
\text { Category }\end{array}$ & $\begin{array}{c}\text { Release } \\
\text { Fraction }\end{array}$ & $\begin{array}{c}\text { Aerosolized } \\
\text { Fraction }\end{array}$ & $\begin{array}{c}\text { Respirable } \\
\text { Fraction }\end{array}$ \\
\hline & & & \\
I & 0 & 0 & 0 \\
II & 0.01 & 1.0 & 1.0 \\
III & 0.1 & 1.0 & 1.0 \\
IV & 1.0 & 1.0 & 1.0 \\
V & 1.0 & 1.0 & 1.0 \\
VI & 1.0 & 1.0 & 1.0 \\
VII & 1.0 & 1.0 & 1.0 \\
VIII & 1.0 & 1.0 & 1.0 \\
\hline
\end{tabular}

Sources: NRC (1977); Neuhauser and Kanipe

(1993).

\subsubsection{Assumptions}

\subsubsection{Release Heights}

Because the most severe accidents normally involve fire, it was assumed that the tritium inside the targets would be released and oxidized. Fire tends to elevate the plume height; hence, the effective release height for the plume was assumed to be at $10 \mathrm{~m}(33 \mathrm{ft})$.

\subsubsection{Population Densities}

Route-specific population densities obtained from HIGHWAY 3.1 were used to calculate potential risks associated with the ground transport of the tritium targets. For the air shipments of the tritium-filled targets, the national average population densities along the route were obtained from NUREG-0170 (NRC 1977) and were assumed to be 6 persons $/ \mathrm{km}^{2}\left(15.5 \mathrm{persons} / \mathrm{mi}^{2}\right)$ rural, 719 persons $/ \mathrm{km}^{2}\left(1,863\right.$ persons $\left./ \mathrm{mi}^{2}\right)$ suburban, and 3,861 persons $/ \mathrm{km}^{2}\left(10,003\right.$ persons $\left./ \mathrm{mi}^{2}\right)$ urban. 


\subsubsection{Locations of Maximally Exposed Individuals}

In the scenario evaluations, the maximally exposed individual in a maximum-consequence accident was placed where the dose to that individual would be at a maximum: $380 \mathrm{~m}(1,250 \mathrm{ft})$ from the site of the accident. Atmospheric stability class $F$ (stable weather conditions with a wind speed of $1 \mathrm{~m} / \mathrm{s}$ [3.3 ft/s]) was used to estimate the maximum dose following a hypothetical transportation accident.

\subsubsection{Per-Shipment Risk Factors and MEI Consequences}

The transportation risk assessment calculated risks associated with the shipment of tritium targets from the manufacturing sites to the proposed NIF locations. Each manufacturing site was assumed to produce $100 \%$ of the tritium targets. In practice, however, several sites might be shipping tritium targets to NIF. Table 4.14 presents the per-shipment risk factors used to calculate the associated risks when shipping tritium targets from the manufacturing sites to the candidate NIF sites. The risk factors are given on a per-shipment-per-curie basis and consider both air and ground transport. Table 4.15 presents the nonradiological risk factors associated with vehicular emissions and transportation accidents. These risk factors are given on a per-shipment basis.

Single-accident consequences are proportional to the amount of tritium shipped and the exposed population. Hence, shipments that contained larger amounts of tritium would result in larger radiological risks for a given population density than a similar accident involving a smaller amount of the same type of target material. Since it is difficult to predict the exact location of a transportation accident, maximum consequence accidents are presented in Table 4.16 for each population density and shipment configuration. The radiological risks were calculated with the RISKIND computer code using the shipping configuration and assumptions provided in Section 4.3.3.

TABLE 4.14 Radiological Per-Shipment Risk Factors

\begin{tabular}{lccccc}
\hline & \multicolumn{4}{c}{ Risk Factors (fatalities per shipment per curie), by Site } \\
\cline { 2 - 6 } \multicolumn{1}{c}{ Source } & LLNL & LANL & NTS & NLVF & SNL \\
\hline \multirow{2}{*}{ General Atomics } & $2 \times 10^{-12}$ & $5 \times 10^{-12}$ & $3 \times 10^{-12}$ & $3 \times 10^{-12}$ & $3 \times 10^{-12}$ \\
Lawrence Livermore & 0 & $5 \times 10^{-12}$ & $3 \times 10^{-12}$ & $3 \times 10^{-12}$ & $3 \times 10^{-12}$ \\
Los Alamos & $5 \times 10^{-12}$ & 0 & $5 \times 10^{-12}$ & $5 \times 10^{-12}$ & $4 \times 10^{-12}$ \\
Savannah River & $4 \times 10^{-12}$ & $6 \times 10^{-12}$ & $5 \times 10^{-12}$ & $5 \times 10^{-12}$ & $3 \times 10^{-12}$ \\
University of Rochester & $4 \times 10^{-12}$ & $6 \times 10^{-12}$ & $5 \times 10^{-12}$ & $5 \times 10^{-12}$ & $4 \times 10^{-12}$ \\
\hline
\end{tabular}


TABLE 4.15 Nonradiological Vehicular Per-Shipment Risk Factors

\begin{tabular}{|c|c|c|c|c|c|}
\hline \multirow[b]{2}{*}{ Source } & \multicolumn{5}{|c|}{ Vehicular Emissions Risk Factors (fatalities/shipment), by Site } \\
\hline & LLNL & LANL & NTS & NLVF & SNL \\
\hline General Atomics & $6.7 \times 10^{-6}$ & $5.3 \times 10^{-6}$ & $6 \times 10^{-6}$ & $5.6 \times 10^{-6}$ & $5.5 \times 10^{-6}$ \\
\hline Lawrence Livermore & 0 & $2.6 \times 10^{-6}$ & $3 \times 10^{-6}$ & $2.9 \times 10^{-6}$ & $2.8 \times 10^{-6}$ \\
\hline Los Alamos & $2.6 \times 10^{-6}$ & 0 & $1 \times 10^{-6}$ & $1.5 \times 10^{-6}$ & $1.4 \times 10^{-6}$ \\
\hline Savannah River & $2.6 \times 10^{-6}$ & $1.2 \times 10^{-6}$ & $1 \times 10^{-6}$ & $1.5 \times 10-6$ & $1.4 \times 10^{-6}$ \\
\hline \multirow[t]{2}{*}{ University of Rochester } & $2.6 \times 10^{-6}$ & $1.2 \times 10^{-6}$ & $1 \times 10^{-6}$ & $1.5 \times 10^{-6}$ & $1.4 \times 10^{-6}$ \\
\hline & \multicolumn{5}{|c|}{ Transportation Accident Risk Factors (fatalities/shipment), by Site } \\
\hline Source & LLNL & LANL & NTS & NLVF & SNL \\
\hline General Atomics & $3.8 \times 10^{-6}$ & $1.2 \times 10^{-5}$ & $7.8 \times 10^{-6}$ & $5.7 \times 10^{-6}$ & $3.4 \times 10^{-6}$ \\
\hline Lawrence Livermore & 0 & $1.3 \times 10^{-5}$ & $8.3 \times 10^{-6}$ & $6.1 \times 10^{-6}$ & $3.9 \times 10^{-6}$ \\
\hline Los Alamos & $1.3 \times 10^{-5}$ & 0 & $1.7 \times 10^{-5}$ & $1.5 \times 10^{-5}$ & $1.2 \times 10^{-5}$ \\
\hline Savannah River & $4.0 \times 10^{-6}$ & $1.3 \times 10^{-5}$ & $8.0 \times 10^{-6}$ & $5.9 \times 10^{-6}$ & $3.6 \times 10^{-6}$ \\
\hline University of Rochester & $2.4 \times 10^{-6}$ & $1.1 \times 10^{-5}$ & $6.4 \times 10^{-6}$ & $4.3 \times 10^{-6}$ & $2.0 \times 10^{-6}$ \\
\hline
\end{tabular}

TABLE 4.16 Radiological Impacts Resulting from a Severity Category VIII Accident for Each Shipment Configuration of Tritium Targets

\begin{tabular}{lcccc}
\hline & \multicolumn{4}{c}{ Impact per Shipment Configuration } \\
\cline { 2 - 5 } \multicolumn{1}{c}{ Parameter } & $1.5 \mathrm{Ci}$ & $7.5 \mathrm{Ci}$ & $15 \mathrm{Ci}$ & $75 \mathrm{Ci}$ \\
\hline & & & & \\
$\begin{array}{l}\text { Impact at accident } \\
\text { location (person-rem) } \\
\quad \begin{array}{l}\text { Rural } \\
\text { Suburban }\end{array}\end{array}$ & $1.0 \times 10^{-4}$ & $5.2 \times 10^{-4}$ & $1.0 \times 10^{-3}$ & $5.2 \times 10^{-3}$ \\
$\quad \begin{array}{l}\text { Urban } \\
\text { Impact to maximally }\end{array}$ & $1.2 \times 10^{-2}$ & $6.2 \times 10^{-2}$ & $1.2 \times 10^{-1}$ & $6.2 \times 10^{-1}$ \\
exposed individual (rem) & $6.7 \times 10^{-2}$ & $3.3 \times 10^{-1}$ & $6.7 \times 10^{-1}$ & 3.3 \\
\hline & $2.4 \times 10^{-5}$ & $1.2 \times 10^{-4}$ & $2.4 \times 10^{-4}$ & $1.2 \times 10^{-3}$ \\
\hline
\end{tabular}


of the tritium that is oxidized. Table 4.13 presents the release, aerosolized (oxidized), and respirable fractions used to conduct this transportation risk assessment.

\subsection{REFERENCES FOR SECTION 4}

American Conference of Government Industrial Hygienists, 1994, Threshold Limit Values and Biological Exposure Indices for 1994-1995, Cincinnati, Ohio.

American Industrial Hygiene Association, 1988, Emergency Response Planning Guidelines, Akron, Ohio.

Brereton, S., 1993, Preliminary Hazards Analysis for the National Ignition Facility, UCRL-D-116983, Lawrence Livermore National Laboratory, Livermore, Calif., Oct.

Brereton, S., 1995, Assessment of the Impact of the Accidental Release of Short-Lived Nuclides for the NIF Section of the PEIS, NIF-LLNL-95-382, Lawrence Livermore National Laboratory, Livermore, Calif., July.

Brown, D., et al., 1996, unpublished data, University of Illinois and Argonne National Laboratory, Champaign and Argonne, Ill.

DOE - See U.S. Department of Energy.

ICRP - See International Commission on Radiological Protection.

International Commission on Radiological Protection, 1991, Recommendations of the International Commission on Radiological Protection, ICRP Publication 60, Pergamon Press, Oxford, England.

Johnson, P.E., et al., 1993, HIGHWAY 3.1, an Enhanced Transportation Routing Model: Program Description, Methodology, and Revised User's Manual, ORNL/TM-12124, Oak Ridge National Laboratory, Oak Ridge, Tenn., March.

Kimura, C., 1996, unpublished data, Lawrence Livermore National Laboratory, Livermore, Calif.

Lawrence Livermore National Laboratory, 1996, National Ignition Facility Draft Preliminary Safety Analysis Report, Livermore, Calif., May 31.

LLNL - See Lawrence Livermore National Laboratory. 
Mishima, J., 1993, Recommended Values and Technical Bases for Airborne Release Fractions, Airborne Release Rates, and Respirable Fractions at DOE Non-Reactor Nuclear Facilities, DOE-HDBK-0013-93, U.S. Department of Energy, Washington, D.C.

Napier, B.A., at el., 1998, GENII - The Hanford Environmental Radiation Dosimetry Software System, PNL-6584, Vol. 1-3, Pacific Northwest Laboratory, Richland, Wash., Dec.

Neuhauser, K.S., and F.L. Kanipe, 1993, RADTRAN 4, Volume II: Technical Manual, SAND892370, Sandia National Laboratories, Albuquerque, N.M., Aug.

NRC — See U.S. Nuclear Regulatory Commission.

Rao, R.K., et al., 1982, Non-Radiological Impacts of Transporting Radioactive Material, SAND811703, TTC-0236, Sandia National Laboratories, Albuquerque, N.M.

Reynolds, R.M, 1992, ALOHA ${ }^{\mathrm{TM}}$ (Areal Locations of Hazardous Atmospheres) 5.0: Theoretical Description, NOAA-TM NOS ORCA-65, National Oceanic and Atmospheric Administration, Seattle, Wash., Aug.

Saricks, C., and T. Kvitek, 1994, Longitudinal Review of State-Level Accident Statistics for Carriers of Interstate Freight, ANL/ESD/TM-68, Argonne National Laboratory, Argonne, Ill., March.

Singh, M., et al., 1995, NIF: Reevaluation of Facility Classification and Radiological Impacts, Rev. 1: Data Renormalization to 385 MJ and 1200 MJ Annual Yields, NIF-LLNL-95-187, Lawrence Livermore National Laboratory, Livermore, Calif., July.

Tobin, M., and S. Brereton, 1995, "Information Concerning the NIF Target Transport Options for the NIF Volume of the PEIS for Stockpile Stewardship and Management," letter from Tobin and Brereton (Lawrence Livermore National Laboratory, Livermore, Calif.) to J.M. Yatabe (Lawrence Livermore National Laboratory, Livermore, Calif.), July 12.

U.S. Bureau of the Census, 1991, 1990 Census of Population and Housing, U.S. Department of Commerce, Washington, D.C.

U.S. Department of Energy, 1992, Hazard Classification and Accident Analysis Techniques for Compliance with DOE Order 5480.23, Nuclear Facility Safety Analysis Reports, DOE-STD1027-92, Washington, D.C., Dec. 1992.

U.S. Department of Energy, 1996, Programmatic Environmental Impact Statement for Stockpile Stewardship and Management, DOE/EIS-0236, Office of Reconfiguration, Washington, D.C. 
U.S. Nuclear Regulatory Commission, 1977, Final Environmental Statement on the Transportation of Radioactive Material by Air and Other Modes, NUREG-0170, Washington, D.C.

Yuan, Y.C., et al., 1993, RISKIND-A Computer Program for Calculating Radiological Consequences and Health Risks from Transportation of Spent Nuclear Fuel, ANL/EAIS-6, Rev. 0, Argonne National Laboratory, Argonne, Ill., Feb. 


\section{THREATENED, ENDANGERED, AND RARE SPECIES}

This section includes tabular information on federal- and state-protected species that inhabit or could occur at the candidate NIF sites. Protected species are listed in Table 5.1 for LLNL, Table 5.2 for LANL, Table 5.3 for the NTS, Table 5.4 for the NLVF, and Table 5.5 for SNL. Each table provides information on common and scientific names, protection status, habitat, and potential to occur at the candidate NIF locations.

The classification system for federally protected species is based on definitions set forth in the Endangered Species Act of 1973 and subsequent amendments. Federal status terms reported in the tables are:

- Endangered (E): $\quad$ Any species in danger of extinction throughout all or a significant part of its range.

- Threatened (T): $\quad$ Any species likely to become an endangered species throughout all or a significant part of its range.

- Candidate 1 (C1): $\quad$ Species for which the U.S. Fish and Wildlife Service (FWS) has sufficient information on hand to support the biological appropriateness of its being listed as endangered or threatened.

- Candidate 2(C2): Species for which information now in the possession of the FWS indicates the probable appropriateness of listing it being listed as endangered or threatened.

The terminology used by the various states in classifying protected species is specific to each state and is defined in a footnote to each table. 
TABLE 5.1 Threatened, Endangered, and Rare Species Potentially Present at Lawrence Livermore National Laboratory

\begin{tabular}{|c|c|c|c|c|c|}
\hline \multirow[b]{2}{*}{ Common Name } & \multirow[b]{2}{*}{ Scientific Name } & \multicolumn{2}{|c|}{ Status ${ }^{a}$} & \multirow[b]{2}{*}{ Habitat } & \multirow{2}{*}{$\begin{array}{l}\text { Potential to } \\
\text { Occur at } \\
\text { NIF Location }\end{array}$} \\
\hline & & Federal & State & & \\
\hline Hairless popcorn flower & Plagiobothrys glaber & $\mathrm{C} 2$ & - & Coastal salt marshes, wet alkaline soils & Unlikey \\
\hline Hispid bird's beak & Cordylanthus mollis hispidus & $\mathrm{C} 2$ & $\mathrm{R}$ & Saline marshes, flats & Unlikely \\
\hline Palmate bird's beak & Cordylanthus palmatus & $\mathrm{E}$ & $\mathrm{E}$ & $\begin{array}{l}\text { Saline to alkaline soils; in alkali sink } \\
\text { scrub vegetation or relatively undisturbed, } \\
\text { seasonally flooded lowland sites }\end{array}$ & Unlikely \\
\hline San Joaquin saltbush & Atriplex joaquiniana & $\mathrm{C} 2$ & - & Alkaline soils & Unlikely \\
\hline Califomia linderiella & Linderiella occidentalis & $\mathrm{C} 2$ & - & Aquatic & None \\
\hline Callippe silverspot butterfly & Speyeria callippe callippe & $\mathrm{C} 2$ & - & Violets (food plant) & Low \\
\hline Consevancy fairy shrimp & Branchinecta conservatio & $\mathrm{C} 2$ & - & Aquatic & None \\
\hline Curved-foot hygrotus diving beetle & Hygrotus curvipes & $\mathrm{C} 2$ & - & Aquatic & None \\
\hline Longhorned fairy shrimp & Branchinecta longiantenna & $\mathrm{C} 2$ & - & Aquatic & None \\
\hline Molestan blister beetle & Lytta molesta & $\mathrm{C} 2$ & - & Flowers & Low \\
\hline Ricksecker's water scavenger beetle & Hydrochara rickseckeri & $\mathrm{C} 2$ & - & Aquatic & None \\
\hline Vernal pool fairy shrimp & Branchinecta lynchi & $\mathrm{C} 2$ & - & Aquatic & None \\
\hline California red-legged frog & Rana aurora draytoni & $\mathrm{C} 2$ & SC & $\begin{array}{l}\text { Marshes; slow portions of streams, lakes, } \\
\text { reservoirs, ponds. Most common in } \\
\text { wooded areas of lowlands and foothills }\end{array}$ & Unlikely \\
\hline California tiger salamander & Ambystoma tigrinum californiense & $\mathrm{C} 2$ & SC & $\begin{array}{l}\text { Open woodlands and grasslands; requires } \\
\text { aquatic habitats for breeding. }\end{array}$ & Unlikely \\
\hline Alameda whipsnake & Masticophis lateralis euryxanthus & $\mathrm{C} 2$ & $\mathrm{~T}$ & $\begin{array}{l}\text { Associated with chaparral, but can also } \\
\text { occur in grasslands, open woods, rocky } \\
\text { slopes, open streams, arroyos }\end{array}$ & Low \\
\hline California horned lizard & Phrynosoma coronatum frontale & $\mathrm{C} 2$ & $\mathrm{SC}$ & $\begin{array}{l}\text { Brushland, coniferous forests, and } \\
\text { broadleaf woodlands. Most common in } \\
\text { lowlands along sandy washes with } \\
\text { scattered low bushes }\end{array}$ & Unlikely \\
\hline Bald eagle & Haliaeetus leucocephalus & $\mathbf{T}$ & $\mathbf{E}$ & Lakes, reservoirs, rivers, coastlines & None \\
\hline
\end{tabular}


TABLE 5.1 (Cont.)

\begin{tabular}{|c|c|c|c|c|c|}
\hline \multirow[b]{2}{*}{ Common Name } & \multirow[b]{2}{*}{ Scientific Name } & \multicolumn{2}{|c|}{ Status $^{\mathrm{a}}$} & \multirow[b]{2}{*}{ Habitat } & \multirow{2}{*}{$\begin{array}{l}\text { Potential to } \\
\text { Occur at } \\
\text { NIF Location }\end{array}$} \\
\hline & & Federal & State & & \\
\hline White-tailed kite & Elanus caeruleus & - & $\mathbf{R}$ & $\begin{array}{l}\text { Open groves, river valleys, marshes, } \\
\text { grasslands }\end{array}$ & Low \\
\hline Burrowing owl & Athene cunicularia & $\mathrm{C} 2$ & SC & $\begin{array}{l}\text { Open grasslands, prairies, farmland, } \\
\text { airfields }\end{array}$ & Low \\
\hline Cooper's hawk & Accipiter cooperi & - & SC & $\begin{array}{l}\text { Mature forests, open woodlands, wood } \\
\text { edges, river groves }\end{array}$ & Unlikely \\
\hline Golden eagle & Aquila chrysaetos & - & SC & $\begin{array}{l}\text { Open mountains, foothills, plains, open } \\
\text { country }\end{array}$ & Unlikely \\
\hline Northern harrier & Circus cyaneus & - & SC & Fields, marshes, prairies & Low \\
\hline Peregrine falcon & Falco peregrinus & E & $E$ & $\begin{array}{l}\text { Wetlands, woodlands, forest, cities, } \\
\text { agricultural areas, cliff faces, coastal } \\
\text { habitats }\end{array}$ & None \\
\hline Prairie falcon & Falco mexicanus & - & SC & $\begin{array}{l}\text { Mountainous grasslands, open hills, } \\
\text { plains, prairies }\end{array}$ & Unlikely \\
\hline Sharp-shinned hawk & Accipiter striatus & - & SC & $\begin{array}{l}\text { Open deciduous woodlands, mixed or } \\
\text { coniferous forests, thickets, edges }\end{array}$ & Unlikely \\
\hline Short-eared owl & Asio flammeus & - & SC & Prairies, marshes, dunes, tundra & Unlikely \\
\hline Swainson's hawk & Buteo swainsoni & - & $\mathbf{T}$ & $\begin{array}{l}\text { Nests peripherally to riparian areas or in } \\
\text { lone trees or tree groves in agricultural } \\
\text { fields; requires large open grasslands for } \\
\text { foraging }\end{array}$ & Unlikely \\
\hline Tricolored blackbird & Agelaius tricolor & $\mathrm{C} 2$ & - & $\begin{array}{l}\text { Cattail and tule marshes; forages in fields } \\
\text { and farms }\end{array}$ & Low \\
\hline Badger & Taxidea taxus & - & SC & Grasslands, forest edges & Low \\
\hline
\end{tabular}


TABLE 5.1 (Cont.)

\begin{tabular}{|c|c|c|c|c|c|}
\hline \multirow[b]{2}{*}{ Common Name } & \multirow[b]{2}{*}{ Scientific Name } & \multicolumn{2}{|c|}{ Status $^{\mathrm{a}}$} & \multirow[b]{2}{*}{ Habitat } & \multirow{2}{*}{$\begin{array}{l}\text { Potential to } \\
\text { Occur at } \\
\text { NIF Location }\end{array}$} \\
\hline & & Federal & State & & \\
\hline San Joaquin kit fox & Vulpes mocrotis mutica & $\mathrm{E}$ & $\mathrm{T}$ & $\begin{array}{l}\text { Open, level, sandy ground; low desert } \\
\text { vegetation, junipers, grasslands }\end{array}$ & Low \\
\hline Greater western mastiff bat & Eumops perotis californicus & $\mathrm{C} 2$ & SC & Buildings, cliff crevices, trees, tunnels & Unlikely \\
\hline Pacific western big-eared bat & Plecotus townsendii townsendii & $\mathrm{C} 2$ & SC & Caves, mine tunnels, buildings & Unlikely \\
\hline Pallid bat & Antrozous pallidus & - & SC & $\begin{array}{l}\text { Rocky outcrops and crevices, buildings, } \\
\text { caves, mines, hollow trees }\end{array}$ & Unlikely \\
\hline Riparian woodrat & Neotoma fuscipes riparia & $\mathrm{C} 2$ & SC & $\begin{array}{l}\text { Heavy chaparral, streamside thickets, } \\
\text { deciduous or mixed woods }\end{array}$ & Unlikely \\
\hline San Joaquin pocket mouse & Perognathus inornatus inornatus & $\mathrm{C} 2$ & - & $\begin{array}{l}\text { Dry, open, grassy or weedy areas; fine- } \\
\text { textured soil }\end{array}$ & Low \\
\hline
\end{tabular}

a Federal status definitions: $\mathrm{E}=$ endangered, $\mathrm{T}=$ threatened, $\mathrm{C} 2=$ candidate 2 (see text for details); state status definitions: $\mathrm{E}=$ endangered, $\mathrm{T}=$ threatened, $\mathrm{R}=$ rare, $\mathrm{SC}=$ species of special concern. A dash $(-)$ indicates not listed.

Sources: Burt and Grossenheider (1976); California Department of Fish and Game (1991); DOE and UC (1992); Jones et al. (1985); Peterson (1990); Stebbins (1966). 
TABLE 5.2 Threatened, Endangered, and Rare Species Potentially Present at Los Alamos National Laboratory

\begin{tabular}{|c|c|c|c|c|c|}
\hline \multirow[b]{2}{*}{ Common Name } & \multirow[b]{2}{*}{ Scientific Name } & \multicolumn{2}{|c|}{ Status $^{\mathbf{a}}$} & \multirow[b]{2}{*}{ Habitat } & \multirow{2}{*}{$\begin{array}{c}\text { Potential to } \\
\text { Occur at } \\
\text { NIF Location }\end{array}$} \\
\hline & & Federal & State & & \\
\hline Grama grass cactus & Pediocactus papyracanthus & $\mathrm{C} 2$ & - & $\begin{array}{l}\text { Grasslands, pinyon-juniper woodlands } \\
(1,525 \text { to } 2,225 \mathrm{~m})\end{array}$ & Low \\
\hline Sandia alumroot & Heuchera pulchella & - & RS & Rock crevices & Low \\
\hline Paper-spined cactus & Epipactis gigantea & $\mathrm{C} 2$ & $\mathrm{E}$ & Pinyon-juniper & Low \\
\hline Santa Fe cholla & Opuntia viridiflora & - & $\mathrm{E}$ & Pinyon-juniper $(2,200$ to $2,440 \mathrm{~m})$ & Low \\
\hline Wood lily & Lilium philadelphicuin & - & $\mathrm{E}$ & $\begin{array}{l}\text { Ponderosa to mixed conifer cliffs }(1,800 \text { to } \\
3,050 \mathrm{~m})\end{array}$ & Unlikely \\
\hline Wright's fishhook cactus & Mammillaria wrightii & - & $\mathbf{E}$ & $\begin{array}{l}\text { Desert grassland to pinyon-juniper ( } 915 \text { to } \\
2,135 \mathrm{~m} \text { ) }\end{array}$ & Low \\
\hline Say's pond snail & Lymnaea captera & - & $\mathbf{E}$ & Aquatic & None \\
\hline Flathead chub & Platygobio gracilis & $\mathrm{C} 2$ & - & Sandy runs of small to large turbid rivers & None \\
\hline Jemez Mountain salamander & Plethodon neomexicanus & $\mathrm{C} 2$ & $\mathbf{E}$ & Densely wooded, shady canyons & None \\
\hline Northern goshawk & Accipiter gentilis & $\mathrm{C} 2$ & - & $\begin{array}{l}\text { Ponderosa; dense, mature, or old-growth } \\
\text { coniferous forest }\end{array}$ & Moderate \\
\hline Ferruginous hawk & Buteo regalis & $\mathrm{C} 2$ & - & Grasslands & Unlikely \\
\hline Common black hawk & Buteogallus anthracinus & - & E & Riparian areas with cottonwoods & Unlikely \\
\hline Broad-billed hummingbird & Cynanthus latirostris & - & $\mathrm{T}$ & Riparian woodlands & Unlikely \\
\hline Southwestern willow flycatcher & Empidonax traillii extimus & $\mathrm{E}$ & $\mathrm{T}$ & $\begin{array}{l}\text { Willows, thickets, brushy pastures, old } \\
\text { orchards }\end{array}$ & Low \\
\hline Peregrine falcon & Falco peregrinus & $\mathrm{E}$ & E & Ponderosa-pinyon, streams, lakes & Unlikely \\
\hline Whooping crane & Grus americana & $\mathrm{E}$ & $\mathrm{E}$ & Prairie ponds, marshes & None \\
\hline Bald eagle & Haliaeetus leucocephalus & $\mathbf{T}$ & $\mathrm{T}$ & Riparian areas near streams and lakes & None \\
\hline Mississippi kite & Ictinia mississippiensis & - & $\mathrm{E}$ & Riparian areas and shelterbelts & Unlikely \\
\hline Loggerhead shrike & Lanius ludovicianus & $\mathrm{C} 2$ & - & Grasslands, open woodlands & Moderate \\
\hline White-faced ibis & Plegadis chihi & $\mathrm{C} 2$ & - & Streams, marshes, ponds & None \\
\hline Gray vireo & Vireo vicinior & - & $\mathrm{T}$ & $\begin{array}{l}\text { Brushy mountain slopes, mesas, open } \\
\text { chaparral, scrub oaks, junipers }\end{array}$ & Moderate \\
\hline
\end{tabular}


TABLE 5.2 (Cont.)

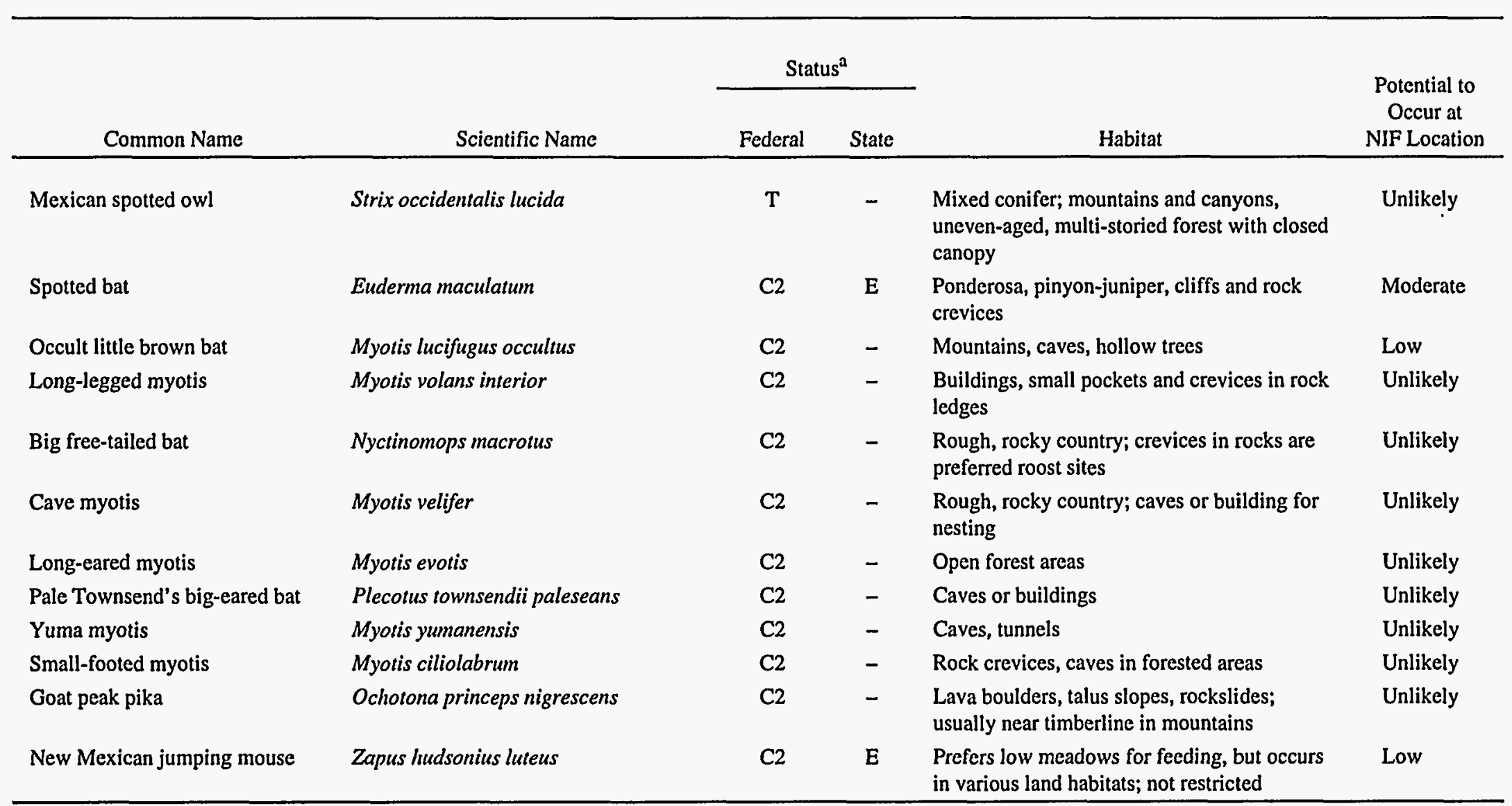

a Federal status definitions: $\mathrm{E}=$ endangered, $\mathrm{T}=$ threatened, $\mathrm{C} 2=$ candidate 2 (see text for details); state status definitions: $\mathrm{E}=$ endangered, $\mathrm{T}=$ threatened, RS = rare and sensitive plant species. A dash (-) indicates not listed.

Sources: Burt and Grossenheider (1976); DOE (1995a-b); Jones et al. (1985); LANL (1993); New Mexico Department of Game and Fish (1995); Page and Burr (1991); Peterson (1990). 
TABLE 5.3 Threatened, Endangered, and Rare Species Potentially Present at Nevada Test Site

\begin{tabular}{|c|c|c|c|c|c|}
\hline \multirow[b]{2}{*}{ Common Name } & \multirow[b]{2}{*}{ Scientific Name } & \multicolumn{2}{|c|}{ Status $^{\mathrm{a}}$} & \multirow[b]{2}{*}{ Habitat } & \multirow{2}{*}{$\begin{array}{l}\text { Potential to } \\
\text { Occur at } \\
\text { NIF Location }\end{array}$} \\
\hline & & Federal & State & & \\
\hline Beatley milkvetch & Astragalus beatleyae & $\mathrm{Cl}$ & $\mathrm{CE}$ & $\begin{array}{l}\text { Shallow gravelly soil in open volcanic } \\
\text { bedrock }\end{array}$ & None \\
\hline Beatley phacelia & Phacelia beatleyae & $\mathrm{C} 2$ & - & $\begin{array}{l}\text { Gravel/volcanic tuff, canyon washes, steep } \\
\text { barren slopes }\end{array}$ & None \\
\hline Black wooly-pod & Astragalus funereus & $\mathrm{C} 2$ & - & $\begin{array}{l}\text { Unstable, steep gravelly slopes of volcanic } \\
\text { tuff }\end{array}$ & None \\
\hline Amargosa penstemon & Penstemon fruticiformis var. amargosae & $\mathrm{C} 2$ & - & Along washes & None \\
\hline Beardtongue & Penstemon pahutensis & $\mathrm{C} 2$ & - & Mesas, slopes & None \\
\hline Cane spring suncup & Camissonia megalantha & $\mathrm{C} 2$ & - & Shad scale, disturbed soil & Unlikely \\
\hline Sanicle biscuitroot & Cymopterus ripleyi var. saniculoides & $\mathrm{C} 2$ & - & Sandy soils & Unlikely \\
\hline Green-gentian & Frasera pahutensis & $\mathrm{C} 2$ & - & Gravelly slopes, valley bottoms & None \\
\hline Kingston bedstraw & Galium hilendiae kingstonense & $\mathrm{C} 2$ & - & Ravines, gulleys & None \\
\hline Mojave fishhook cactus & Sclerocactus polyancistrus & - & $\mathrm{CY}$ & Yucca Mountain area & Unlikely \\
\hline White bear desert-poppy & Arctomecon merriamii & $\mathrm{C} 2$ & - & Shallow gravelly soil, limestone outcrop & Unlikely \\
\hline Devil's Hole pupfish & Cyprinodon diabolis & $\mathbf{E}$ & $\mathbf{E}$ & Deep limestone pool, Devil's Hole & None \\
\hline Chuckwalla & Sauromalus obesus & $\mathrm{C} 2$ & - & $\begin{array}{l}\text { Rock dweller (lava flows, rocky hillsides, } \\
\text { outcrops); feeds on creosote bush }\end{array}$ & Low \\
\hline Desert tortoise & Gopherus agassizii & $\mathrm{T}$ & $\mathrm{T}$ & $\begin{array}{l}\text { Washes, rocky hillsides, and flat desert } \\
\text { having sandy and gravelly soil; bushes, } \\
\text { cacti, etc, required for cover }\end{array}$ & Moderate \\
\hline Bald eagle & Haliaeetus leucocephalus & $\mathrm{T}$ & $\mathrm{E}$ & Lakes, reservoirs, rivers, coastlines & None \\
\hline Ferruginous hawk & Buteo regalis & $\mathrm{C} 2$ & - & Woodlands, grasslands & Unlikely \\
\hline Loggerhead shrike & Lanius ludovicianus & $\mathrm{C} 2$ & - & Most habitats & Low \\
\hline Mountain plover & Charadrius montanus & $\mathrm{C} 2$ & - & Semi-arid plains, grasslands, plateaus & Unlikely \\
\hline Peregrine falcon & Falco peregrinus & $\mathrm{E}$ & $\mathbf{E}$ & Open country, cliffs & Unlikely \\
\hline
\end{tabular}




\section{TABLE 5.3 (Cont.)}

\begin{tabular}{|c|c|c|c|c|c|}
\hline \multirow[b]{2}{*}{ Common Name } & \multirow[b]{2}{*}{ Scientific Name } & \multicolumn{2}{|c|}{ Status $^{\mathrm{a}}$} & \multirow[b]{2}{*}{ Habitat } & \multirow{2}{*}{$\begin{array}{l}\text { Potential to } \\
\text { Occur at } \\
\text { NIF Location }\end{array}$} \\
\hline & & Federal & State & & \\
\hline Western least bittern & Ixobrychus exilis hesperis & $\mathrm{C} 2$ & - & Marshes, weedy ponds & None \\
\hline Western snowy plover & Charadrius alexandrinus nivosus & $\mathrm{C} 2$ & - & Sand flats, beaches & None \\
\hline White-faced ibis & Plegadis chihi & $\mathrm{C} 2$ & - & Marshes, irrigated lands, tules & None \\
\hline Fringed myotis & Myotis thysanodes & $\mathrm{C} 2$ & - & Caves and buildings & Unlikely \\
\hline Long-eared myotis & Myotis evotis & $\mathrm{C} 2$ & - & Open forest areas & Unlikely \\
\hline Long-legged myotis & Myotis volans & $\mathrm{C} 2$ & - & $\begin{array}{l}\text { Buildings, small pockets and crevices in } \\
\text { rock ledges }\end{array}$ & Unlikely \\
\hline Pacific Townsend's big-eared bat & Plecotus townsendii townsendii & $\mathrm{C} 2$ & - & Caves or buildings & Unlikely \\
\hline Small-footed myotis & Myotis ciliolabrum & $\mathrm{C} 2$ & - & Rock crevices, caves in forested areas & Unlikely \\
\hline Spotted bat & Euderma maculatum & $\mathrm{C} 2$ & - & $\begin{array}{l}\text { Arid country, occasionally buildings and } \\
\text { caves }\end{array}$ & $\begin{array}{r}\text { Unlikely } \\
\text {. }\end{array}$ \\
\hline Yuma myotis & Myotis yumanensis & $\mathrm{C} 2$ & - & Caves, tunnels & Unlikely \\
\hline
\end{tabular}

a Federal status definitions: $\mathrm{E}=$ endangered, $\mathrm{T}=$ threatened, $\mathrm{C} 1=$ candidate $1, \mathrm{C} 2=$ candidate 2 (see text for details); state status definitions: $\mathrm{CE}=$ critically endangered, $\mathrm{E}=$ endangered, $\mathrm{T}=$ threatened, $\mathrm{CY}=$ protected by authority of Nevada Cacti and Yucca Law. A dash $(-)$ indicates not listed.

Sources: DOE (1995c); Peterson (1990); Stebbins (1966). 
TABLE 5.4 Threatened, Endangered, and Rare Species Potentially Present at North Las Vegas Facility

\begin{tabular}{|c|c|c|c|c|c|}
\hline \multirow[b]{2}{*}{ Common Name } & \multirow[b]{2}{*}{ Scientific Name } & \multicolumn{2}{|c|}{ Status ${ }^{a}$} & \multirow{2}{*}{ Habitat } & \multirow{2}{*}{$\begin{array}{l}\text { Potential to } \\
\text { Occur at } \\
\text { NIF Location }\end{array}$} \\
\hline & & Federal & State & & \\
\hline Desert tortoise & Gopherus agassizii & $\mathrm{T}$ & $\mathrm{T}$ & $\begin{array}{l}\text { Washes, rocky hillsides, and flat deserts having sandy and gravelly } \\
\text { soil; bushes, cacti, etc. required for cover }\end{array}$ & Unlikely \\
\hline
\end{tabular}

a Federal status definition: $\mathrm{T}=$ threatened (see text for details); state status definition: $\mathrm{T}=$ threatened.

Source: Stebbins (1966). 
TABLE 5.5 Threatened, Endangered, and Rare Species Potentially Present at Sandia National Laboratories

\begin{tabular}{|c|c|c|c|c|c|}
\hline \multirow[b]{2}{*}{ Common Name } & \multirow[b]{2}{*}{ Scientific Name } & \multicolumn{2}{|c|}{ Status ${ }^{\mathrm{a}}$} & \multirow[b]{2}{*}{ Habitat } & \multirow{2}{*}{$\begin{array}{l}\text { Potential to } \\
\text { Occur at } \\
\text { NIF Location }\end{array}$} \\
\hline & & Federal & State & & \\
\hline Club cholla & Opuntia clavata & - & SP1 & Grasslands & Low \\
\hline Cyanic milkvetch & Astragalus cyaneus & - & $\mathrm{T}$ & Grasslands, arroyos & Unlikely \\
\hline Grama grass cactus & Pediocactus papyracanthus & $\mathrm{C} 2$ & $\mathrm{E}$ & Grasslands & Unlikely \\
\hline Great Plains lady tresses & Spiranthes magnicamporum & - & $\mathrm{E}$ & Grasslands & Unlikely \\
\hline Plank's catchfly & Silene plankii & - & $\mathrm{T}$ & Grasslands & Unlikely \\
\hline Santa Fe milkvetch & Astragalus feensis & - & $\mathrm{T}$ & Grasslands, arroyos & Unlikely \\
\hline Simpson's cactus & Pediocactus simpsonii & - & $\mathrm{E}$ & Grasslands & Unlikely \\
\hline Strong prickly pear & Opuntia valida & - & UR & Grasslands, woodlands & Unlikely \\
\hline White visnagita & Neolloydia intertexta & - & $\mathrm{E}$ & Open woodlands & None \\
\hline Wright's pincushion & Mammillaria wrightii & - & $\mathrm{E}$ & Open woodlands & None \\
\hline Millipede & Toltecus chihuanus & $\mathrm{C} 2$ & - & Grasslands & Unlikely \\
\hline Rio Grande silvery minnow & Hybognathus amarus & $\mathrm{E}$ & $\mathbf{T}$ & Pools and backwaters of Rio Grande & None \\
\hline Flathead chub & Platygobio gracilis & $\mathrm{C} 2$ & - & Sandy runs of small to large turbid rivers & None \\
\hline Texas horned lizard & Phrynosoma cornutum & $\mathrm{C} 2$ & - & $\begin{array}{l}\text { Arid and semi-arid open country with sparse plant } \\
\text { growth; requires loose soil and bushes, burrows, } \\
\text { or rocks for shelter }\end{array}$ & Unlikely \\
\hline Northern goshawk & Accipiter gentilis & $\mathrm{C} 2$ & - & $\begin{array}{l}\text { Forests (especially in mountains), forest edges; } \\
\text { winters in lowlands }\end{array}$ & Unlikely \\
\hline Baird's sparrow & Ammodramus bairdii & $\mathrm{C} 2$ & $\mathbf{E}$ & Native tallgrass prairies & Unlikely \\
\hline Ferruginous hawk & Buteo regalis & $\mathrm{C} 2$ & - & Plains, prairies & Unlikely \\
\hline Common black-hawk & Buteogallus anthracinus anthracinus & - & $\mathrm{T}$ & Wooded stream bottoms & None \\
\hline Northern beardless-tyrannulet & Camptostoma imberbe ridgwayi & - & $\mathrm{E}$ & $\begin{array}{l}\text { Low woods, mesquite, stream thickets, lower } \\
\text { canyons }\end{array}$ & None \\
\hline Mountain plover & Charadrius montanus & $\mathrm{C} 2$ & - & Semi-arid plains, grasslands, plateaus & Unlikely \\
\hline Black tem & Chlidonias niger surinamensis & $\mathrm{C} 2$ & - & Marshes, lakes, coastal waters & None \\
\hline
\end{tabular}


TABLE 5.5 (Cont.)

\begin{tabular}{|c|c|c|c|c|c|}
\hline \multirow[b]{2}{*}{ Common Name } & \multirow[b]{2}{*}{ Scientific Name } & \multicolumn{2}{|c|}{-Status ${ }^{a}$} & \multirow[b]{2}{*}{ Habitat } & \multirow{2}{*}{$\begin{array}{c}\text { Potential to } \\
\text { Occur at } \\
\text { NIF Location }\end{array}$} \\
\hline & & Federal & State & & \\
\hline Southwestern willow flycatcher & Empidonax traillii extrimus & $\mathbf{E}$ & $\mathbf{T}$ & Willow, thickets, brushy pastures, old orchards & Unlikely \\
\hline Peregrine falcon & Falco peregrinus & $\mathrm{E}$ & $\mathrm{E}$ & $\begin{array}{l}\text { Wetlands, woodlands, forest, cities, agricultural } \\
\text { areas, cliff faces, coastal habitats }\end{array}$ & None \\
\hline Gray vireo & Vireo vicinior & - & $\mathbf{E}$ & $\begin{array}{l}\text { Brushy mountain slopes, mesas, open chaparral, } \\
\text { scrub oaks, junipers }\end{array}$ & Unlikely \\
\hline Swainson's hawk & Buteo swainsoni & $\mathrm{C} 2$ & - & Plains, ranges, open hills, sparse trees & Unlikely \\
\hline Whooping crane & Grus americana & $\mathrm{E}$ & $\mathrm{E}$ & Prairie pools, marshes & None \\
\hline Bald eagle & Haliaeetus leucocephalus & $\mathrm{T}$ & $\mathrm{T}$ & Lakes, reservoirs, rivers, coastlines & None \\
\hline Least bittern & Ixobrychus exilis exilis & $\mathrm{C} 2$ & - & Marshes, reedy ponds & None \\
\hline White-faced ibis & Plegadis chihi & $\mathrm{C} 2$ & - & Streams, marshes, ponds & None \\
\hline Burrowing owl & Speotyto cunicularia hypugaea & $\mathrm{C} 2$ & - & Open grassland, prairies, farmlands, airfields & Unlikely \\
\hline Mexican spotted owl & Strix occidentalis lucida & $\mathbf{T}$ & - & $\begin{array}{l}\text { Mature old-growth forests, conifers, wooded } \\
\text { canyons }\end{array}$ & None \\
\hline Bell's vireo & Vireo bellii & - & $\mathrm{T}$ & Willows, streamsides & Unlikely \\
\hline Arizona black-tailed prairie dog & Cynomys ludovicianus arizonensis & $\mathrm{C} 2$ & - & $\begin{array}{l}\text { Semi-arid prairies; thrives on overgrazed } \\
\text { rangelands; avoids tall grass }\end{array}$ & Unlikely \\
\hline Spotted bat & Euderma maculatum & $\mathrm{C} 2$ & $\mathrm{E}$ & $\begin{array}{l}\text { Arid country; occasionally enters buildings and } \\
\text { caves }\end{array}$ & Unlikely \\
\hline Great western mastiff bat & Eumops perotis californicus & $\mathrm{C} 2$ & - & Buildings, crevices, trees, tunnels & Unlikely \\
\hline Western small-footed myotis & Myotis ciliolabrum melanorhinus & $\mathrm{C} 2$ & - & Caves, rock crevices & None \\
\hline Occult little brown myotis & Myotis lucifugus occultus & $\mathrm{C} 2$ & - & Mountains, caves, hollow trees & None \\
\hline Fringed myotis & Myotis thysanodes thysanodes & $\mathrm{C} 2$ & - & Caves, attics & Unlikely \\
\hline Long-legged myotis & Myotis volans interior & $\mathrm{C} 2$ & - & $\begin{array}{l}\text { Buildings, small pockets and crevices in rock } \\
\text { ledges }\end{array}$ & Unlikely \\
\hline Yuma myotis & Myotis yumanensis yumanensis & $\mathrm{C} 2$ & - & Caves, tunnels, or buildings; arid areas & Unlikely \\
\hline Big free-tailed bat & Nyctinomops macrotis & $\mathrm{C} 2$ & - & Rough, rocky country; crevices in rocks & None \\
\hline Pecos River muskrat & Ondatra zibethicus ripensis & $\mathrm{C} 2$ & - & $\begin{array}{l}\text { Marshes and other shallow water where emergent } \\
\text { vegetation is abundant }\end{array}$ & None \\
\hline
\end{tabular}


TABLE 5.5 (Cont.)

\begin{tabular}{|c|c|c|c|c|c|}
\hline \multirow[b]{2}{*}{ Common Name } & \multirow[b]{2}{*}{ Scientific Name } & \multicolumn{2}{|c|}{ Status $^{\mathbf{a}}$} & \multirow[b]{2}{*}{ Habitat } & \multirow{2}{*}{$\begin{array}{c}\text { Potential to } \\
\text { Occur at } \\
\text { NIF Location }\end{array}$} \\
\hline & & Federal & State & & \\
\hline Townsend's big-eared bat & Plecotus townsendii pallescens & $\mathrm{C} 2$ & - & Caves, mine tunnels, buildings & Unlikely \\
\hline Colorado chipmunk & Eutamias quadrivitatus australis & $\mathrm{C} 2$ & $\mathrm{~T}$ & Coniferous forests, rocky slopes, ridges & Low \\
\hline New Mexican jumping mouse & Zapus hudsonius luteus & $\mathrm{C} 2$ & - & $\begin{array}{l}\text { Prefers low meadows for feeding, but occurs in } \\
\text { various land habitats; not restricted }\end{array}$ & Low \\
\hline
\end{tabular}

a Federal status definitions: $\mathrm{E}=$ endangered, $\mathrm{T}=$ threatened, $\mathrm{C} 2=$ candidate 2 (see text for details); state status definitions: $\mathrm{E}=$ endangered, $\mathrm{SP} 1=$ state priority 1 , $\mathrm{T}=$ threatened species endemic to New Mexico or of restricted and decreasing abundance, $\mathrm{UR}=$ under review by New Mexico Forestry and Resource Conservation Division. A dash $(-)$ indicates not listed.

Sources: Burt and Grossenheider (1976); IT Corporation et al. (1992); Jones et al. (1985); New Mexico Department of Game and Fish (1995); Page and Burr (1991); Peterson (1990); Stebbins (1966); Wheeler (1995). 


\section{REFERENCES FOR SECTION 5}

Burt, R.B., and R.P. Grossenheider, 1976, A Field Guide to the Mammals, Houghton Mifflin Co., Boston, Mass.

California Department of Fish and Game, 1991, 1990 Annual Report on the Status of California's State Listed Threatened and Endangered Plants and Animals, State of California, The Resources Agency, Department of Fish and Game, Sacramento, Calif., March.

DOE - See U.S. Department of Energy.

DOE and UC - See U.S. Department of Energy and University of California.

IT Corporation et al., 1992, Sandia National Laboratories, Albuquerque Environmental Baseline Update, Albuquerque, N.M., May.

Jones, J.K., Jr., et al., 1985, Guide to Mammals of the Plains States, University of Nebraska Press, Lincoln, Neb.

LANL — See Los Alamos National Laboratory.

Los Alamos National Laboratory, 1993, RFI Work Plan for Operable Unit 1111, Final Draft, Environmental Restoration Program, Los Alamos, N.M.

New Mexico Department of Game and Fish, 1995, New Mexican Wildlife of Special Concern by County, Conservation Services Division, Biota Information System of New Mexico (BISON-M), Santa Fe, N.M.

Page, L.M., and B.M. Burr, 1991, A Field Guide to Freshwater Fishes North America North of Mexico, Houghton Mifflin Co., Boston, Mass.

Peterson, R.T., 1990, A Field Guide to Western Birds, Houghton Mifflin Co., Boston, Mass.

Stebbins, R.C., 1966, A Field Guide to Western Reptiles and Amphibians, Houghton Mifflin Co., Boston, Mass.

U.S. Department of Energy, 1995a, unpublished information, Washington, D.C.

U.S. Department of Energy, 1995b, Dual Axis Radiographic Hydrodynamic Test Facility Environmental Impact Statement, DOE/EIS-0228, Los Alamos Area Office, Los Alamos, N.M. 
U.S. Department of Energy, 1995c, Programmatic Environmental Impact Statement for Tritium Supply and Recycling, Vols. I and II, DOE/EIS-0161, Office of Reconfiguration, Washington, D.C.

U.S. Department of Energy and University of California, 1992, Final Environmental Impact Statement and Environmental Impact Report for Continued Operation of Lawrence Livermore National Laboratory and Sandia National Laboratories, Livermore, DOE/EIS-0157, U.S. Department of Energy, Sandia National Laboratories, Livermore, Calif., Aug.

Wheeler, T., 1995, letter with attached tables from Wheeler (Sandia National Laboratories, Albuquerque, New Mexico) to M. Lazaro (Argonne National Laboratory, Argonne, Ill.), Nov. 2. 